
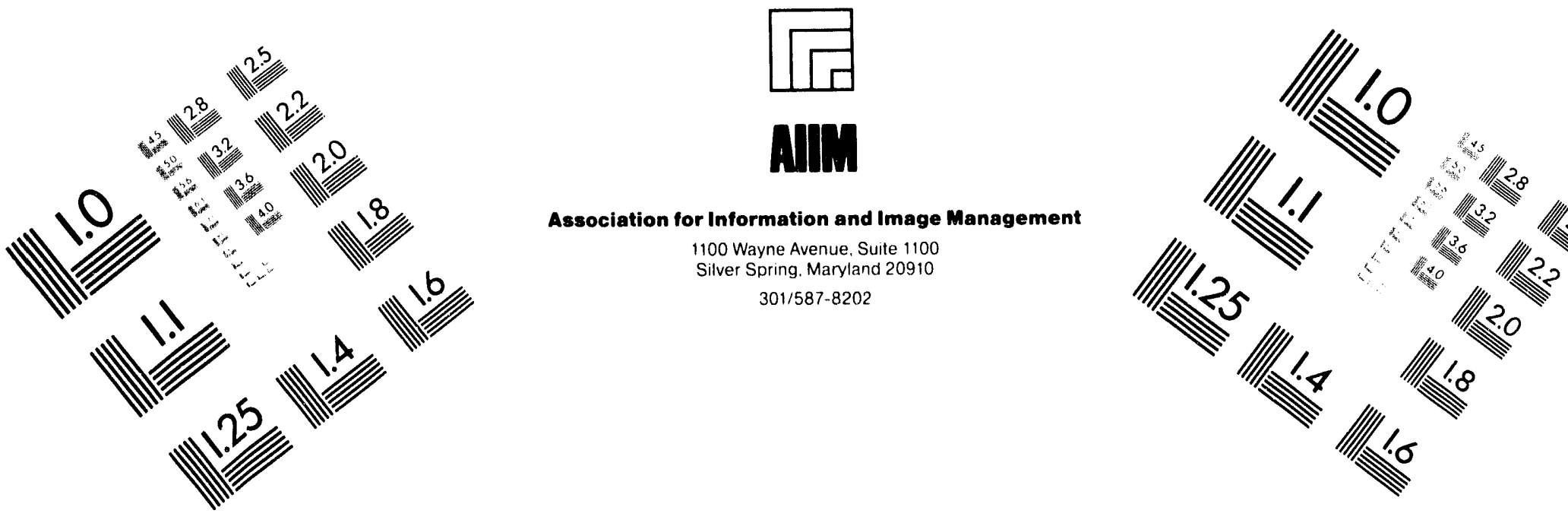

Centimeter

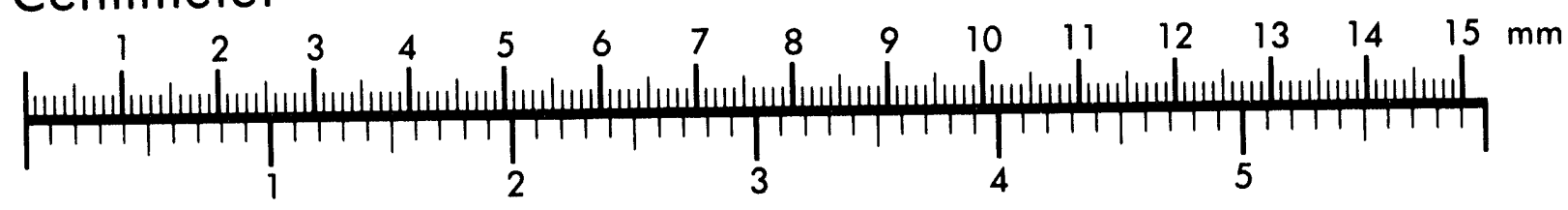

Inches
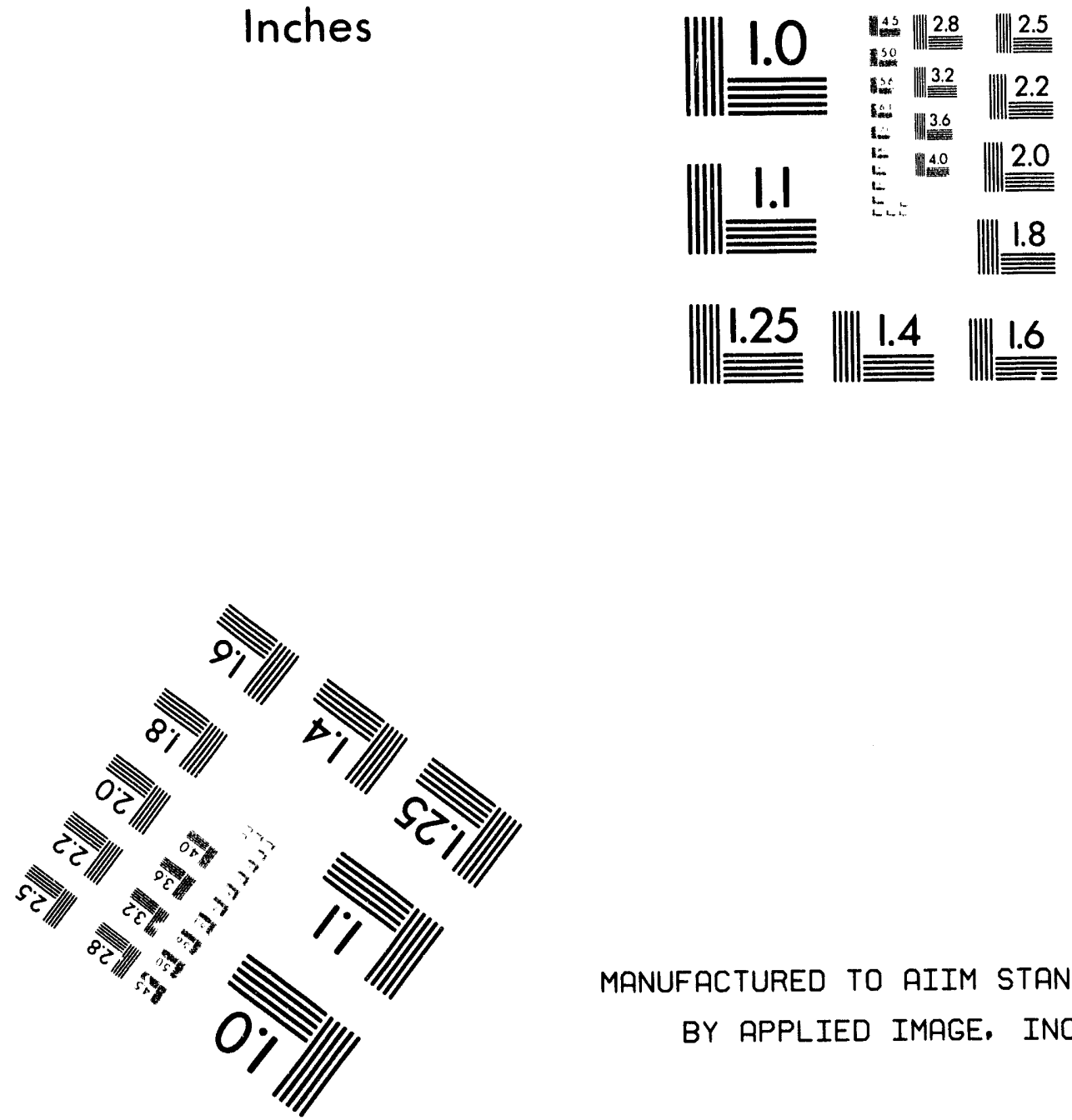

MANUFACTURED TO AIIM STANDARDS

BY APPLIED IMAGE, INC.

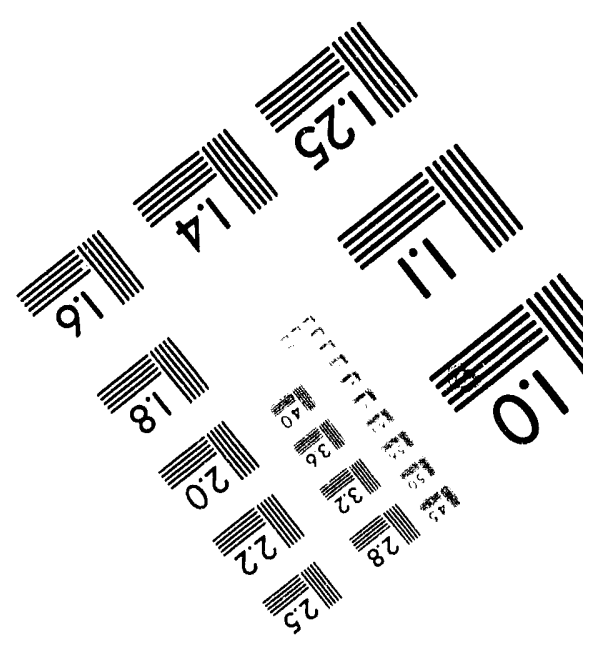



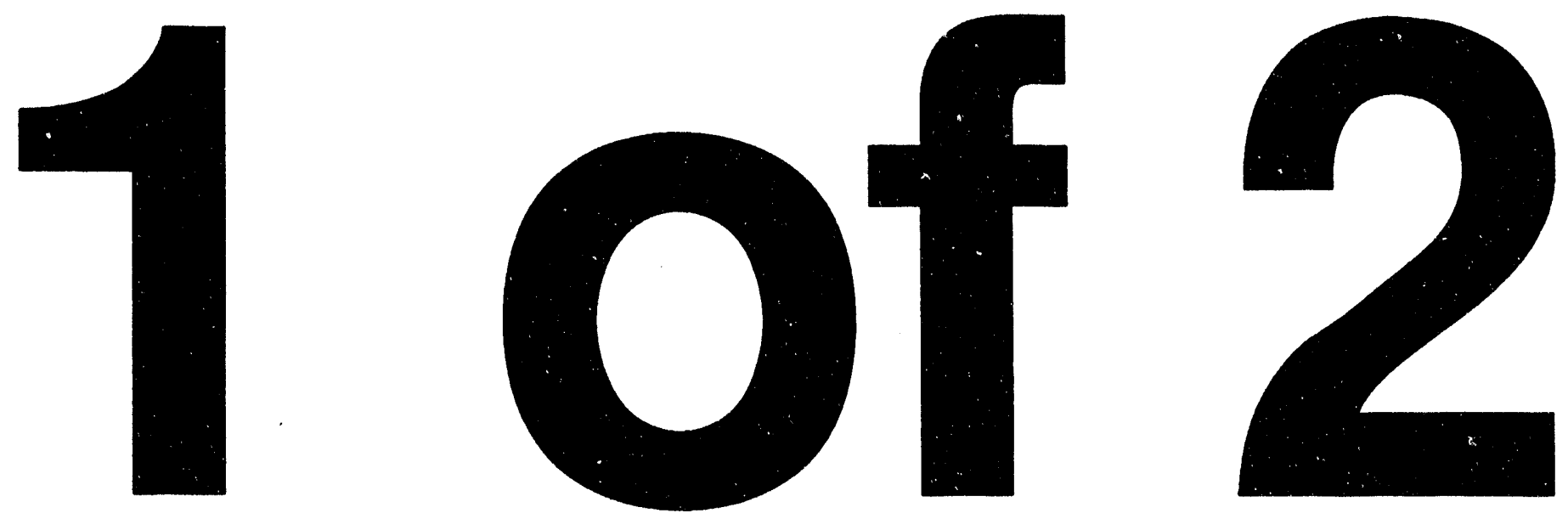


\section{0-FF-1 Operable Unit Remedial Investigation Phase II Report: Physical Separation of Soils Treatability Study}

Date Published

April 1994

\section{DISCLAIMER}

This report was prepared as an account of work sponsored by an agency of the United States Government. Neither the United States Government nor any agency thereof, nor any of their employees, makes any warranty, express or implied, or assumes any legal liability or responsibility for the accuracy, completeness, or usefulness of any information, apparatus, product, or process disclosed, or represents that its use would not infringe privately owned rights. Reference herein to any specific commercial product, process, or service by trade name, trademark, manufacturer, or otherwise does not necessarily constitute or imply its endorsement, recommendation, or favoring by the United States Government or any agency thereof. The views and opinions of authors expressed herein do not necessarily state or reflect those of the United States Government or any agency thereof.

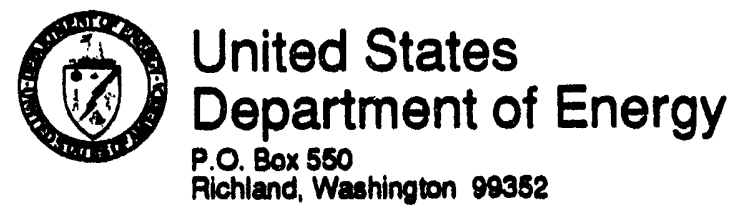

Richland, Washington 99352

$$
\begin{aligned}
& \text { fin } 07 \text { क } \\
& 00 \pi 1
\end{aligned}
$$




\section{ACRONYMS}

ARAR

ART

ASTM

CERCLA

DOE

$\mathrm{dpm}$

DQO

ECN

Ecology

EII

EPA

FS

HEIS

ICP-OES

ICP-MS

ICR

IT

LSA

MTCA

ORR

PCB

PNL

QA

QC

RCRA

RESRAD

RI

RL

ROD

TCLP

WHC

XRD

XRF

applicable or relevant and appropriate requirements Alternative Remedial Technologies

American Society for Testing and Materials

Comprehensive Environmental Response, Compensation, and Liability Act

U.S. Department of Energy

disintegration per minute

data quality objectives

Engineering Change Notice

Washington Department of Ecology

environmental investigation instructions

U.S. Environmental Protection Agency

feasibility study

Hanford Environmental Information System

inductively coupled plasma - optical emission spectrometry

inductively coupled plasma - mass spectrometry

incremental cancer risk

International Technologies Laboratories

low specific activity

Model Toxics Control Act

operational readiness review

polychlorinated biphenyls

Pacific Northwest Laboratory

quality assurance

quality control

Resource Coriservation and Recovery Act

Residual Radioactivity Program

remedial investigation

Richland Operations

record of decision

Toxicity Characteristic Leaching Procedure

Westinghouse Hanford Company

$x$-ray diffraction

$x$-ray fluorescence 


\section{UNITS OF MEASURE}

\section{Radiation}

- Roentgen (R) - The roentgen is a unit for measuring exposure. It is defined only for effect on air. It applies only to gamma and $x$-rays. It does not relate biological effects of radiation to the human body.

- Rad (radiation absorbed dose) - The rad is a unit for measuring absorbed does in any material. Absorbed dose results from energy being deposited by the radiation. It is defined for any material. It applies to all types of radiation. It does not take into account the potential effect that different types of radiation have on the body.

- Rem (roentgen equivalent man) - The rem is a unit for measuring dose equivalence. It is the most commonly "sed unit and pertains to man. The rem takes into account the energy absorbed (dose) and the biological effect on the body due to the different types of radiation.

\section{Milli-Units}

Units in roentgen, rad, and rem can be broken down into smaller, more usable units called milli-units. Milli-units are one one-thousandth of a whole unit. An example is:

$1 \mathrm{R}$ (roentgen) $=1,000$ milliroentgen $(\mathrm{mR})$

$$
\begin{aligned}
& 1 \mathrm{rad}=1,000 \mathrm{millirad} \text { (mrad) } \\
& 1 \mathrm{rem}=1,000 \mathrm{milli} \text { irem (mrem). }
\end{aligned}
$$

\section{Dose Rate}

Dose is the amount of radiation you receive. Dose rate is the rate at: which you receive the dose.

\section{Contamination/Radioactivity}

- Contamination units:

- disintegrations per minute (dpm) or per second (dps)

- counts per minute (cpm)

- Radioactivity is measured in the number of disintegrations radioactive material undergoes in a certain period of time.

One curie (unit of radioactivity) =

$$
\begin{array}{r}
2,200,000,000,000\left(2.2 \times 10^{12}\right) \mathrm{dpm} \\
\text { or } \\
37,000,000,000\left(3.7 \times 10^{10}\right) \mathrm{dps} .
\end{array}
$$

For the radioactivity in air and water, the curie ( $C i$ ) or microcurie $(\mu \mathrm{C} i)$ is most often used. One curie equals one million microcuries. 


\section{CONTENTS}

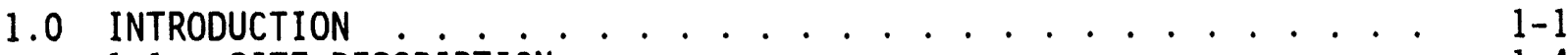

1.1 SITE DESCRIPTION ..................... . . . . . . . . . .

1.2 WASTE STREAM DESCRIPTION ............. . . . $1-5$

1.2.1 Performance Levels and Risk Drivers ......... . 1-5

1.2.2 Radioactivity of Soils ............ 1-6

1.2.3 Soil Characterization and Treatment Tests ..... 1-6

1.3 REMEDIAL TECHNOLOGY DESCRIPTION ........... 1-7

2.0 TEST OBJECTIVES AND RATIONALE .............. 2-1

2.1 OBJECTIVES . . . . . . . . . . . . . . . . . . . . . . . 2-1

2.2 POTENTIAL ARARS . . . . . . . . . . . . . . . .

2.3 DATA QUALITY OBJECTIVES ............. . . . . $2-3$

3.0 EQUIPMENT AND MATERIALS . . . . . . . . . . . . . . 3-1

4.0 SAMPLING AND ANALYSIS . . . . . . . . . . . . . 4-1

4.1 PRE-PROCESS SAMPLES ............... . . . . $4-1$

4.2 PROCESS SAMPLES . . . . . . . . . . . . . 4-2

4.3 POST-PROCESS SAMPLES ............. . . 4-3

4.3.1 >150 mm Material .............. 4-3

4.3.2 150 to $25 \mathrm{~mm}$ Material . . . . . . . . . . . . 4-3

4.3.3 25 to $2 \mathrm{~mm}$ Material ............. 4- 4-4

4.3.4 2 to $0.425 \mathrm{~mm}$ Material ............ . 4-4

$4.3 .5<0.425 \mathrm{~mm}$ Material . . . . . . . . . . . 4-4

4.4 ANALYSES AND VALIDATION .............. 4 4-4

5.0 PRE-TEST . . . . . . . . . . . . . . 5-1

6.0 TEST \#1 . . . . . . . . . . . . . . . . . . 6-1

6.1 FEED SOILS AND FRESH WATER ............ 6- . 6-6

6.1 .1 Particle Size Distribution . . . . . . . 6-6

6.1 .2 Analytical Results . . . . . . . . . 6-6

6.2 PROCESSED SOILS AND EFFLUENT . . . . . . . . . . . . . 6 6-7

6.2 .1 Separation Efficiency . . . . . . . . . . . 6-7

6.2.2 Analytical Results ............ 6-11

6.3 JUNE 29 PROCESSING RESULTS . . . . . . . . . . 6-18

6.4 ATTRITION SCRUBBING . . . . . . . . . . . . 6 6-20

6.5 DATA DISCREPANCIES ............... . . . 6-25

6.6 . RECOMMENDATIONS FOR TEST \#2 . . . . . . . . . . . 6 6-26

7.0 TEST \#2 . . . . . . . . . . . . . . . . . . 7-1

7.1 FEED SOILS AND FRESH WATER ........... $7-3$

7.1.1 Particle Size Distribution ......... . 7-3

7.1.2 Analytical Results ........... 7-.

7.2 PROCESSED SOILS AND EFFLUENT . . . . . . . . . 7 7-5

7.2.1 Separation Efficiency . . . . . . . . . . 7-5

7.2 .2 Analytical Results ............ . 7-8

7.3 SEPTEMBER 9 TESTING $\ldots \ldots \ldots$. . . . . . . . . . .

8.0 WATER TREATMENT .................... . . . . . .

8.1 APPROACH ................... . . . . . . . .

8.2 RESULTS ................... $8-4$ 
9.0 RESIDUALS MANAGEMENT ..................... . . $9-1$

10.0 DATA MANAGEMENT . . . . . . . . . . . . . . . . . . . . . 10-1

11.0 QUALITY ASSURANCE/QUALITY CONTROL . . . . . . . . . . . . . . . . 11-1

11.1 DATA QUALIFIERS AND FLAGS . . . . . . . . . . . . . . . . 11-1

11.2 SUMMARY OF PARCC PARAMETERS . . . . . . . . . . . . . . . . 11-4

11.2.1 Precision .. . . . . . . . . . . . . . . . . . . 11-4

11.2.2 Accuracy . . . . . . . . . . . . . . . . . . . 11-4

11.2.3 Representativeness . . . . . . . . . . . . 11-4

11.2 .4 Completeness . . . . . . . . . . . . . . . 11-5

11.3 SURVEILLANCES

12.0 COMPARISON OF TEST RESULTS WITH PERFORMANCE STANDARDS . . . . . . 12-1

13.0 DEVIATIONS FROM THE TEST PLAN . . . . . . . . . . . . . . 13-1

$14.0 \operatorname{cosT}$. . . . . . . . . . . . . . . . . . 14-1

14.1 LABOR . . . . . . . . . . . . . . . . . . . . 14-1

14.2 MATERIALS AND CONSUMABLES . . . . . . . . . . . . . . 14-3

14.3 UTILITIES . . . . . . . . . . . . . . . . . . . . . . . . 14-4

14.4 ANALYTICAL COSTS . . . . . . . . . . . . . . . 14-5

14.5 MAINTENANCE COSTS . . . . . . . . . . . . . . . . . . . . 14-6

14.6 COST SUMMARY . . . . . . . . . . . . . . . . . . . . . . . 14-6

15.0 CONCLUSIONS AND RECOMMENDATIONS . . . . . . . . . . . . . 15-1

16.0 REFERENCES ...................... . . . . . . . 16

\section{APPENDICES :}

A. Purgewater Acceptance Standards . . . . . . . . . . . . . A-1

B. Analytical Data ................... . . . B-1

\section{FIGURES:}

1-1 The Hanford Site, Richland, Washington ............ . 1-2

1-2 The 300-FF-1 Operable Unit, North Process Pond . . . . . . . . . 1-3

1-3 EPA Modified Physical Separation/Soi1-Washing System . . . . . . 1-11

6-1 System Configuration/Material Balance for Test \#1 . . . . . . . 6-2

6-2a Average Wet-Sieved Size Distribution of Feed Soils in $6-8$

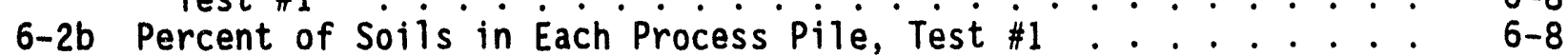

6-3a Test \#1, Wet-Sieved Size Distribution of Processed Soils, Uranium-238 Gamma Spectrometry . . . . . . . . . . . . 6-15

6-3b Test \#1, Contaminant Concentrations in Each Process pile, Uranium-238 Gamma Spectrometry ... . . . . . . . . . 6-15 
DOE/RL-93-96, Rev. 0

CONTENTS (Cont)

FIGURES (Cont):

6-4a Test \#1, Wet-Sieved Size Distribution of Processed Soils, Uranium-235 Gamma Spectrometry . . . . . . . . . . . . . . . 6-16

6-4b Test \#1, Contaminant Concentrations in Each Process Pile, Uranium-235 Gamma Spectrometry . . . . . . . . . . . . . . . 6-16

6-5a Test \#1, Wet-Sieved Size Distribution of Processed Soils, Cobalt-60 Gamma Spectrometry . . . . . . . . . . . . . . . 6-17

6-5b Test \#1, Contaminant Concentrations in Each Process Pile, Cobalt-60 Gamma Spectrometry . . . . . . . . . . . . . . . 6-17

6-6a Test \#1 Distribution of Uranium-238 by Particle Size, Before and After Attrition Scrubbing . . . . . . . . . . . . . . . . . 6-22

6-6b Test \#1 Uranium-238 Levels in Each Process Pile Size Fraction, Before and After Attrition Scrubbing . . . . . . . . . . 6-22

6-7a Test \#1 Distribution of Uranium-235 by Particle Size, Before and After Attrition Scrubbing . . . . . . . . . . . . 6-23

6-7b Test \#1 Uranium-235 Levels That Would Be in Each Process Pile Size Fraction, Before and After Attrition Scrubbing . . . . . . 6-23

6-8a Test \#1 Distribution of Cobalt-60 by Particle Size, Before and After Attrition Scrubbing . . . . . . . . . . . . . 6-24

6-8b Test \#1 Cobalt-60 Levels That Would Be in Each Process Pile Size Fraction, Before and After Attrition Scrubbing . . . . . . 6-24

7-1 System Configuration/Material Balance for Test \#2 . . . . . . . . 7-2

7-2a Average Wet-Sieved Size Distribution of Feed Soils in Test \#2 ................ . . 7-6

7-2b Percent of Soils in Each Process Pile, Test \#2 . . . . . . 7-6

7-3a Test \#1, Wet-Sieved Size Distribution of Processed Soils, Uranium-238 Gamma Spectrometry . . . . . . . . . . . . . 7-12

7-3b Test \#2, Contaminant Concentrations in Each Process Pile, Uranium-238 Gamma Spectrometry . . . . . . . . . . . . . 7-12

7-4a Test \#2, Wet-Sieved Size Distribution of Processed Soils, Uranium-235 Gamma Spectrometry . . . . . . . . . . . . 7-13

7-4b Test \#2, Contaminant Concentrations in Each Process Pile, Uranium-235 Gamma Spectrometry . . . . . . . . . . . . . . . 7-13

7-5a Test \#2, Wet-Sieved Size Distribution of Processed Soils, Coba!t-60 Gamma Spectrometry .. . . . . . . . . . . . . 7-14

7-5b Test \#2, Contaminant Concentrations in Each Process Pile,
Cobalt-60 Gamma Spectrometry . . . . . . . . . . . . . 7-14

8-1 Schematic of the Water Treatment System . . . . . . . . . . 8-2

\section{TABLES:}

1-1 300-FF-1 North Pond Particle Size Distribution . . . . . . . . 1-8

1-2 300-FF-1 North Pond Radiochemical Contaminants by Size Fraction 1-8

1-3 300-FF-1 North Pond Chemical Contaminants by Size Fraction . . 1-9

2-1 Background Levels of Contaminants and Test Performance Levels for Soil Treatability Tests . . . . . . . . . . . . 2-2

2-2 Potential ARARs for the Soil Treatability Test . . . . . . . . 2-4

4-1 Samples and Hanford Environmental Information System (HEIS) Numbers for Test \#1 . . . . . . . . . . 4-1

4-2 Samples and HEIS Numbers for Test \#2 . . . . . . . . . . . 4-2 
TABLES (Cont):

5-1 Summary of Pre-test Processing Activities . . . . . . . . . . . 5-1

6-1 Summary of Test \#1 Activities . . . . . . . . . . . . . . . . . 6-1

6-2 Equipment Operating Parameters and Flow Measurements for Equipment in Test \#1 ...... . . . . . . . . . 6-3

6-3 Wet-Sieved Size Distribution of Feed Soils in Test \# . . . . . . 6-7

6-4 Chemical and Radiochemical Analyses of Feed Soils $<25 \mathrm{~mm}$ and Feed Water for Test \#1 . . . . . . . . . . . . . . 6-9

6-5 Composition of Green and White Sediment in the 300-FF-1 North Pond . . . . . . . . . . . . . . . . . . . 6-10

6-6 Sieve Analyses for Soil Fractions Processed in Test \#1 . . . . 6-11

6-7 Summary of GM Probe Field Radioactivity Measurements . . . . . . 6-12

6-8 Test \#1 Analyses for Each of the Process Streams and Unfiltererl Effluent ................ . 6-13

6-9 Test \#1, Size D.stribution of Contaminants in Processed Soils After Wet-Sieving . . . . . . . . . . . . . . . . 6-14

6-10 Filtered Screening Analyses of Processed Effluent Samples Collected for Test \#1 . . . . . . . . . . . . . . . . 6-19

6-11 Test \#1, June 29 Run, Wet-Sieved Analyses for Processed Soil Fractions ................... . 6-20

6-12 Size Distribution of Dry-Sieved, Wet-Sieved, and AttritionScrubbed/Wet-Sieved Soils from the 0.425to 2-mm Process Pile

6-13 Size Distribution of Radiochemical Isotopes After Attrition Scrubbing, Test \#1 . . . . . . . . . . . . 6-21

7-1 Summary of Test \#2 Activities . . . . . . . . . . . . . . . . 7-1

7-2 Equipment Operating Parameters and Flow Measurements for Test \#2 . . . . . . . . . . . . . . . . . . . . . . . . 7-4

7-3 Test \#2, Wet-Sieved Size Distribuition of Feed Soils . . . . . . 7-5

7-4 Test \#2, September 8, Chemical and Radiochemical Analyses of Feed Soils $<25 \mathrm{~mm}^{\mathrm{a}}$ and Feed Water .......... . 7-7

7-5 Sieve Analyses for Soil Fractions Processed in Test \#2 . . . . 7-8

7-6 Test \#2 Laboratory Analyses for Each of the Process Piles . . . 7-9

7-7 Test \#2 Size Distribution of Contaminants in Processed Soils, After Wet-Sieving .................. . 7-11

8-1 Water Treatment Samples and Analyses as of March 4, 1994 . . . . 8-3

11-1 Analytical Methods, Analytical Parameters, Detection Limits, Precision and Accuracy Requirements.......... . . 11-2

12-1 Summary of Test Results and Test Performance Leveis for Uranium-238, Uranium-235, Cobalt-60, and Chromium . . . . . 12-2

12-2 Comparison Levels for Uranium-238, Uranium-235, Cobalt-60, and Chromium .............. 12-2

14-1 Direct Labor Requirements . . . . . . . . . . . . . . . . 14-2

14-2 Support Labor Costs .. . . . . . . . . . . . . . . . . . . 14-2

14-3 Materials and Consumables costs ............. 14-3

14-4 Utility Costs ...................... 14-5

14-5 Analytical Costs .................... . 14-5

14-6 Maintenance Costs . . . . . . . . . . . . . . . . . . . . . 14-6

14-7 Full-Scale Operation Cost Summary ............. . 14-7 


\subsection{INTRODUCTION}

This report describes the approach and results of physical separations treatability tests conducted under the Comprehensive Environmental Response, Compensation, and Liability Act (CERCLA) at the Hanford Site (Figure 1-1) in the North Process Pond of the 300-FF-1 Operable Unit (Figure 1-2). The report is in fulfillment of Hanford Federal Facility Agreement and Consent Order (Tri-Party Agreement) (Ecology et al. 1989) M!ilestone M-15-03B to submit the draft 300-FF-1 remedial investigation (RI) Phase II report to the U.S. Environmental Protection Agency (EPA) and Washington Department of Ecology (Ecology) for review by December 15, 1993.

Physical separation of soils was identified in the Phase I and II Feasibility Study Report for the 300-FF-1 Operable Unit (DOE-RL 1993a) as an alternative for remediation for which treatability studies were required to demonstrate effectiveness and provide information for the Phase III feasibility study (FS) to be submitted to EPA and Ecology by August 15, 1994 in fulfillment of Tri-Party Agreement Milestone M-15-03C. Physical separation of soils was identified as a remediation alternative due to the potential to significantly reduce the amount of contaminated soils prior to disposal. Additional treatment of fines by chemical extraction or other means was not tested due to the small fraction of fine soils that would require treatment, increased cost, systern complexity, and concerns associated with potential environmental impact.

The scope of this report is limited to investigations and discussions of tests conducted in the north process pond. However, because contaminated soils are similar in the south process pond, process trenches, scraping disposal area, and sanitary trenches (DOE-RL 1993a), test results are expected to apply to these sites also. The volume of contaminated material in these areas and the north process pond is estimated at 645,000 yd $\mathrm{yd}^{3}$ (DOE-RL 1993a, Table $(-1)$. Physical separation may also be used to reduce the amount of contaminated soils removed in burial grounds, and for radioactive surface soils (hot spots) throughout the 300-FF-1 Operable Unit.

Tests were conducted by Westinghouse Hanford Company (WHC), Richland, Washington, personnel using a system developed at Hanford consisting of modified EPA equipment integrated with screens, hoppers, conveyors, tanks, and pumps from the Hanford Site. The EPA equipment was transferred to the U.S. Department of Energy (DOE) by the EPA Risk Reduction Engineering Laboratory, Edison, New Jersey. Tests were conducted per 300-FF-1 Physical Separations CERCLA Treatability Test Plan (DOE-RL 1993b). Under CERCLA, no federal, state, or local permits were required (40 CFR $300.400[\mathrm{e}][1])$.

Except for toxic characteristic leaching procedures (TCLP) conducted by Thermo Analytical Inc. (TMA), Richmond, California, all offsite analytical support for testing of soil and process effluent samples was provided by International Technologies, Richland, Washington, and Data-Chem, Salt Lake City, Utah, laboratories. Offsite analys is of samples collected during water treatment tests was conducted by TMA. Soil sieving, screening analyses during physical separation and water treatment tests, and 1aboratory attrition scrubbing (high energy mixing of soils resulting in a scrubbing of particles as they attrite against each other) were conducted onsite by Pacific Northwest Laboratory (PNL), Richland, Washington. 
Figure 1-1. The Hanford Site, Richland, Washington.

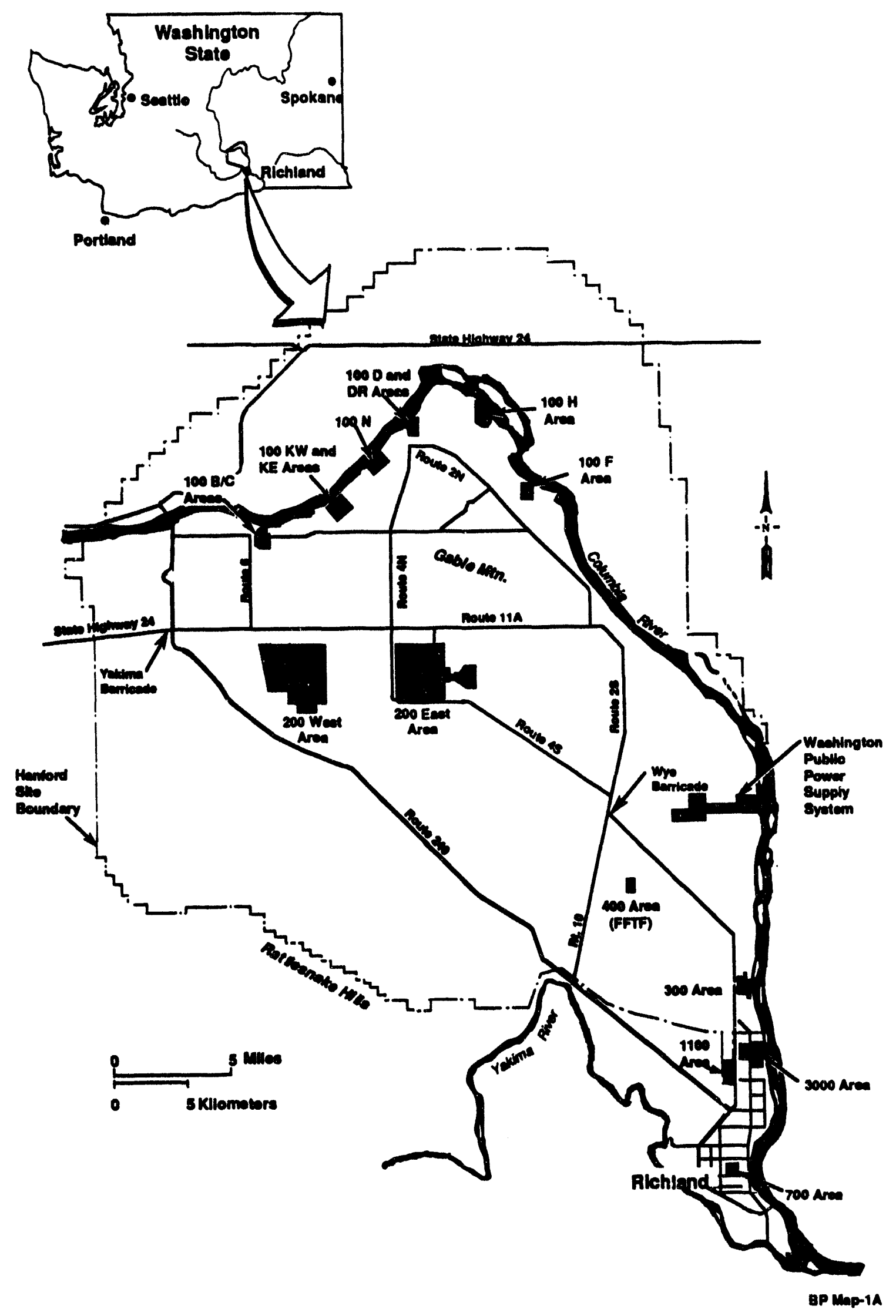


DOE/RL-93-96, Rev. 0

Figure 1-2. The 300-FF-1 Operable Unit, North Process Pond.

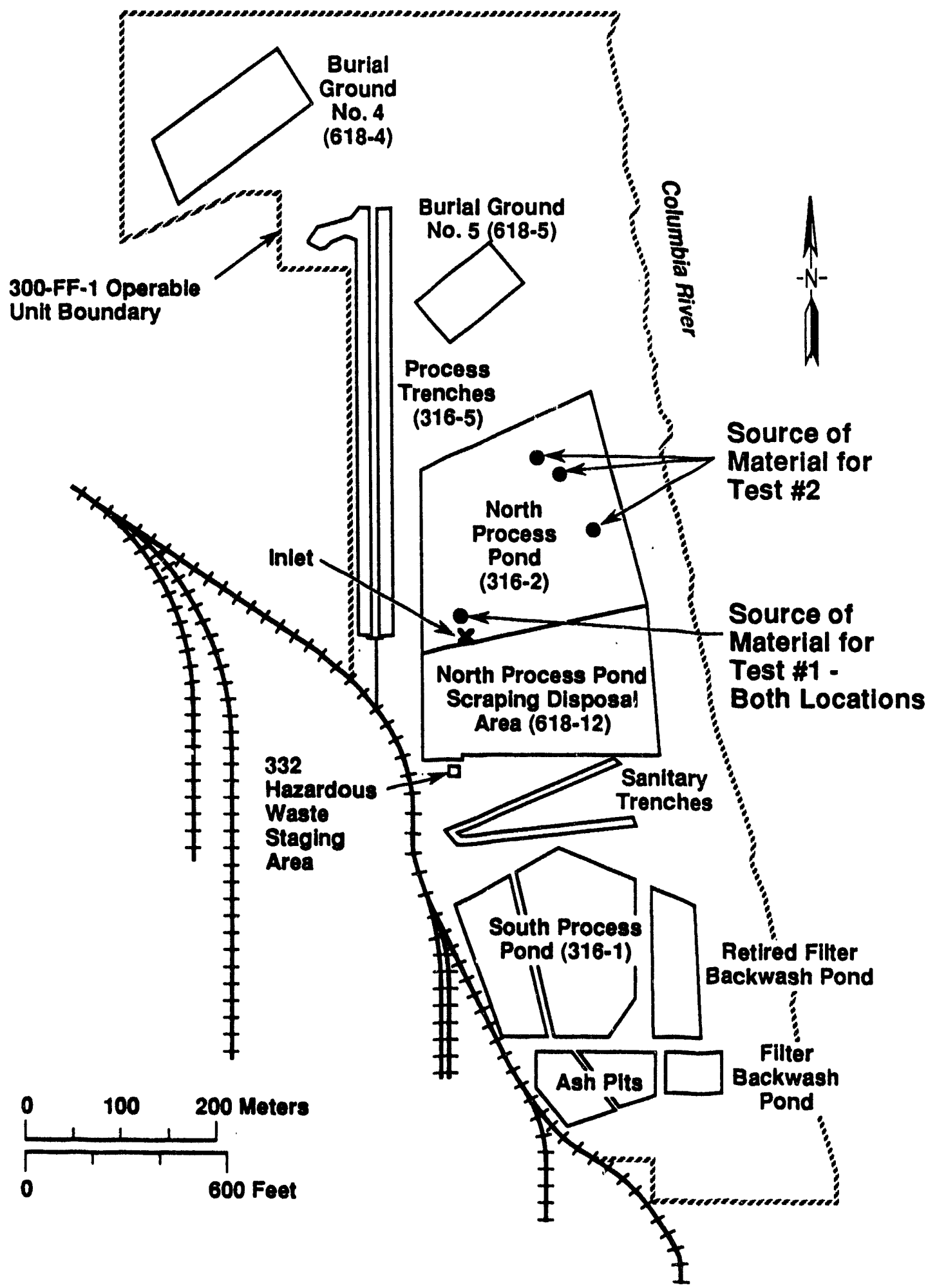

H9311025.1b 
Because of contract delays, tests scheduled to be conducted by an offsite vendor using a commercial system will not be performed until after preparation of this report. The purposes of the vendor test are to demonstrate use of a commercial system, compare results with this report, show that attrition scrubber laboratory tests discussed in this report can be duplicated in the field, and to obtain additional scale-up and cost information for a full-scale system. A contract has been placed with Alternative Remedial Technologies, (ART), Tampa, Florida, to perform this work, currently scheduled to start in March 1994. On completion, a supporting document will be prepared by ART to document test results.

The treatability tests discussed in this report consisted of four parts, in which an estimated 84 tons of soil was processed: (1) a pre-test run to set up the system and adjust system parameters for soils to be processed; (2) a baseline run to establish the performance of the system - Test \#1; (3) a final run in which the system was modified as a result of findings from the baseline run - Test \#2; and (4) water treatment.

\subsection{SITE DESCRIPTION}

The 300-FF-1 Operable Unit is located north of the city of Richland, Washington, and borders the Columbia River (see Figure 1-1). It covers an area of $0.57 \mathrm{~km}^{2}$ and consists of approximately $0.14 \mathrm{~km}^{2}$ of liquid disposal waste sites. Waste sites within the 300-FF-1 Operable Unit are shown on Figure 1-2. Each of the sites is posted as a surface contamination area. The depth to groundwater beneath the 300-FF-1 Operable Unit ranges from 12 to $20 \mathrm{~m}$ (DOE-RL 1990).

The sanitary trenches received sewage from the 300 Area. The sewage is routed through vitreous tile pipes to septic tanks located between the north and south process ponds. Septic tanks are cleaned periodically and the sludge deposited in an adjacent pit near the southwest end of the trenches.

Burial grounds No. 4 and No. 5 are located on the northwest corner of the operable unit. Burial ground No. 4 contains elongated pits filled with solid waste and backfilled with clean soil. The burial ground is known to contain miscellaneous uranium-contaminated materials. Burial ground No. 5 was used for incineration and burial of uranium-contaminated and nonradioactive trash collected from the 300 Area. In addition, radioactive crucibles with aluminum-silicon or lead were disposed in burial ground No. 5 .

The north and south process ponds and trenches were used between 1943 and 1975 to receive process sewer waste that included process water from nuclear fuels fabrication operations, cooling water, steam condensate, water treatment salts, and a wide variety of waste liquids from laboratory drains throughout the 300 Area. The north pond was constructed in 1948 when a dike in the south pond failed. As with the south pond, the north pond had no outlet; water was allowed to evaporate or infiltrate into the soils underlying the pond. The ponds were dredged periodically to improve infiltration. The dredged soils were spread on the dikes or buried in the north pond scrapings disposal area. Parts of the north process pond were used to dispose of fly ash from the 300 Area ash pits (Dennison et a1. 1989). The ponds were deactivated in 1975 and currently do not contain any liquids. 
The process trenches were constructed in 1975 to replace the process ponds to receive laboratory waste. In 1991, sediments were removed from the trenches and stockpiled at the north end as part of an expedited response action (ERA) in an effort to prevent the mobilization of soil-adsorbed contaminants to the groundwater. The process trenches are currently in use, but scheduled to be discontinued when the 300 Area Effluent Treatment Facility is on-line.

The north process pond scraping disposal area extends approximately $60 \mathrm{~m}$ south of the north process pond. It was used to dispose of uraniumcontaminated sediment from the pond. The site has been backfilled with fly ash from the ash pits and covered with fill.

Other waste sites shown on Figure 1-2 include: the retired backwash filter poild, ash pits, and filter backwash pond. These are classified as nohazard sites (DOE-RL 1993a).

A more detailed description of the 300-FF-1 Operable Unit is included in the Remedial Investigation/Feasibility Study Work Plan for the 300-FF-1 Operable Unit, Hanford Site, Richland, Washington (DOE-RL 1990) and the Phase I Remedial Investigation Report for the 300-FF-1 Operable Unit (DOE-RL 1993C).

\subsection{NASTE STREAM DESCRIPTION}

Phase I RI field activities to characterize the 300-FF-1 Operable Unit waste sites were completed February 1992. Soils investigations included surface radiation surveys and analys is of samples collected from boreholes and test pits. Results of these investigations are reported by DOE (DOE-RL 1993c).

\subsubsection{Performance Levels and Risk Drivers}

In these soil investigations and the risk assessment presented in the Phase I RI report (DOE-RL 1993c), uranium was found to be the primary contaminant of concern for 300-FF-1 Operable Unit. Uranium-238 and -235 pose the highest lifetime incremental cancer risk (ICR) (2E-03 and 1E-03, respectively [DOE-RL 1993c]). Cobalt-60 is also an important contaminant with a lifetime cancer risk of 2E-04.

Uranium-238, uranium-235, and cobalt-60 are the only contaminants in the operable unit with ICRs over 1E-04. According to the National $0 i 1$ and Hazardous Substances Contingency PI an (40 CFR $300.430[\mathrm{C}][2][\mathrm{i}][\mathrm{A}][2]$ ) and Hanford Site Baseline Risk Assessment Methodology (DOE-RL 1993d), acceptable exposure levels are generally concentration levels that represent an ICR of between $1 E-04$ and $1 E-06$. It is noted that a radioactive contaminant concentration level associated with an ICR of 1E-04 or less is small enough to ensure satisfaction of any current radiation protection standards (e.g., DOE Order 5400.5) pertinent to the Hanford Site (DOE-RL 1993d).

The highest ICR posed by inorganic contaminants is due to chromium (2E-05); this risk is two orders of magnitude less than that for uranium-238, and assumes all chromium detected is hexavalent chromium (chromium remaining 
in the process ponds after years of flushing is actually expected to be the less toxic trivalent chromium). The remaining inorganic and organic contaminants (including polychlorinated biphenyls [PCB]) are associated with ICRs more than two orders of magnitude less than the risk calculated for uranium-238.

According to the National $0 i 1$ and Hazardous Substances Contingency Plan (40 CFR 300.430[c][2][i][A][2]) and DOE-RL (1993d), acceptable exposure levels of systemic toxins are concentration levels to which human populations, including sensitive subgroups, may be exposed without adverse effects during a lifetime or part of a lifetime (i.e, the hazard quotient has a value less than or equal to one). For the 300-FF-1 Operable Unit, the largest hazard quotient is $\mathbf{0 . 4}$, indicating that none of the contaminants pose a systemic toxic hazard.

\subsubsection{Radioactivity of Soils}

Radioactivity levels in soils near the inlet end and on the west side of the north process pond ranged from 15,000 to 35,000 disintegrations per minute $(\mathrm{dpm}) / 100 \mathrm{~cm}^{2}$ ) as measured in the field in tests conducted during June 1993 . Based on field observations, it is estimated that soils containing this level of radioactivity comprise $<0.25$ of the volume of the contaminated soils in the process ponds shown in Figure 1-2.

The surface radioactivity levels of soils in the remaining portions of the north pond were measured at near-background levels (500 dpm, as determined by Health Physics technicians at the site using hand-held instruments). These measurements are consistent with Phase I RI sampling results showing nearbackground radioactivity levels in test pits in the middle and east side of the trench.

The highest radioactivity in the north process pond is found in particles, visible as a "green material", containing uranium-238 and -235 isotopes. The green material is deposited in thin layers at a depth of 1 to $1.5 \mathrm{~m}$ below the pond surface on the west side of the pond (Dennison et al. 1989) and distributed as discrete particles and flakes in soils near the inlet of the ponds. This material resulted in many test complications.

\subsubsection{Soil Characterization and Treatment Tests}

Bench-scale, wet-sieving, and soil characterization tests using material from the north process pond were performed by PNL (Gerber et al. 1991). In the PNL tests, small soil particles were washed through sieves using water and chemical solutions. The results suggest that it is possible to separate coarse soil particles from fine soil particles with higher concentrations of contaminants. Although concentrated, contaminant levels of the fine particles were still low enough (Gerber et al. 1991) that there were no added problems related to handling or exposure to these soils. Also, in these tests, contaminants did not dissolve into the wash water; thus, water treatment needs were expected to be minimal. Testing of larger scale equipment was recommended to assess application of the technology to more coarse soils (Gerber et al. 1991). 
X-ray diffraction (XRD) tests (Dennison et al. 1989) show that the mineralogical composition of the sediment is typical of sediments found throughout the Pasco Basin that consist predominantly of quartz and feldspar with small amounts of clay and mica.

Soil samples collected from the north process pond as part of Phase I RI for the 300-FF-1 Operable Unit were dry sieved and analyzed by Serne et al. (1992) to determine soil particle size distribution and contaminant distribution. Results, summarized in Tables 1-1, 1-2, and 1-3, show that the highest concentration of contaminants is in the fine soil particles. Based on performance levels specified in the test plan for this test, physical separation with water only and without the use of chemical additives at a size fraction of $0.425 \mathrm{~mm}$ may reduce the amount of contaminated soil in the north process pond by $90 \%$ (by weight) or more. A greater reduction in the amount of contaminated soils will be realized if soils can be separated at $<0.425 \mathrm{~mm}$.

\subsection{REMEDIAL TECHNOLOGY DESCRIPTION}

In this document, physical separation refers to a simple and comparatively low-cost water-based technology to separate soil particles by size fraction without the use of chemical processes so that the coarse fraction of soil will meet cleanup limits (test performance levels for the treatability test) and the amount of contaminated soils is significantly reduced.

Physical separation processes for soils are used extensively in the mining and mineral industries to assist in the recovery of valuable constituents. These physical separation processes have been demonstrated by the EPA Superfund Innovative Technology Evaluation Program for Hazardous Waste Remediation (EPA 1989) and used by the Defense Nuclear Agency to remediate radiologically contaminated coral sands (Kochen 1986). The technology was successfully applied in September 1993 to remediate chromium-contaminated soils at the King of Prussia Superfund Site in Winslow County, New Jersey (Rubin 1993).

A typical physical separations system includes: processes to separate coarse soils by particle size or density; additional processes to separate and/or scrub sand and sometimes silt-size particles; dewatering processes for each solids stream; and in-line water treatment processes to recycle and reuse water and thereby minimize the amount of contaminated water generated in the process. Following processing, contaminated soils (typically the fine fraction of soils) and water are disposed of or further treated, and those soils that meet regulatory cleanup limits are returned to the site.

Additional information on physical separation processes is provided by EPA in Technological Approaches to the Cleanup of Radiologically Contaminated Superfund Sites (EPA 1988). 
Table 1-1 300-FF-1 North Pond Particle Size Distribution. (Serne et a1. 1992)

\begin{tabular}{|c|c|c|c|c|c|c|c|c|c|c|c|c|c|}
\hline \multirow[b]{2}{*}{$\underset{\mathbf{g}}{\text { sample, }}$} & \multicolumn{13}{|c|}{ Fraction sizes, $\mathrm{mm}$} \\
\hline & $>50$ & $\begin{array}{l}50 \text { to } \\
37.5\end{array}$ & $\begin{array}{c}37.5 \\
25\end{array}$ to & $\begin{array}{l}25 \text { to } \\
13.2\end{array}$ & $\begin{array}{l}13.2 \\
\text { to } \\
4.75\end{array}$ & $\begin{array}{l}4.75 \\
\text { to } 2\end{array}$ & $\begin{array}{l}2 \text { to } \\
0.425\end{array}$ & $\begin{array}{c}0.425 \\
\text { to } \\
0.25\end{array}$ & $\begin{array}{c}0.25 \\
\text { to } \\
0.15\end{array}$ & $\begin{array}{c}0.15 \\
\text { to } \\
0.075\end{array}$ & $\begin{array}{c}0.075 \\
\text { to } \\
0.045\end{array}$ & $<0.045$ & Totals \\
\hline 1 & 238.48 & 655.89 & 690.83 & 495.57 & 153.95 & 206.92 & 556.20 & 47.43 & 21.26 & 12.54 & 5.38 & 1.76 & $3,086.21$ \\
\hline 2 & $1,050.08$ & 270.96 & 387.31 & 278.75 & 244.93 & 125.78 & 488.21 & 145.39 & 57.63 & 46.32 & 28.77 & 46.51 & $3,170.64$ \\
\hline 3 & 620.32 & 127.61 & 917.82 & 358.37 & 174.51 & 138.45 & 812.37 & 28.55 & 44.54 & 31.62 & 22.66 & 39.25 & $3,316.07$ \\
\hline Tot wt & $1,908.88$ & $1,054.46$ & $1,995.96$ & 1.132 .69 & 573.39 & 471.15 & $1,856.78$ & 221.37 & 123.43 & 90.48 & 56.81 & 87.52 & $9,572.92$ \\
\hline$x$ by we & 19.94 & 11.02 & 20.85 & 11.83 & 5.99 & 4.92 & 19.40 & 2.31 & 1.29 & 0.95 & 0.59 & 0.91 & 100.00 \\
\hline
\end{tabular}

Table 1-2. 300-FF-1 North Pond Radiochemical Contaminants by Size Fraction. (Serne et a1. 1992)

\begin{tabular}{|c|c|c|c|c|c|c|c|c|c|c|c|c|}
\hline \multirow[b]{2}{*}{$\begin{array}{c}\text { Consti tuent, } \\
\mathrm{pCi} / \mathrm{g}\end{array}$} & \multicolumn{12}{|c|}{ Fraction sizes, mm } \\
\hline & $>50$ & \begin{tabular}{|c|}
50 to \\
37.5
\end{tabular} & $\begin{array}{l}37.5 \\
\text { to } 25\end{array}$ & $\begin{array}{l}25 \text { to } \\
13.2\end{array}$ & $\begin{array}{l}13.2 \\
\text { to } \\
4.75\end{array}$ & $\begin{array}{l}4.75 \\
\text { to } 2\end{array}$ & $\begin{array}{l}2 \text { to } \\
0.425\end{array}$ & $\begin{array}{c}0.425 \\
\text { to } \\
0.25\end{array}$ & $\begin{array}{c}0.25 \\
\text { to } \\
0.15\end{array}$ & $\begin{array}{c}0.15 \\
\text { to } \\
0.075\end{array}$ & $\begin{array}{c}0.075 \\
\text { to } \\
0.045\end{array}$ & $<0.045$ \\
\hline Uranium-235 & & & & & & & & & & & & \\
\hline san. 1 & 0.0408 & 0.0618 & 0.213 & 0.275 & 0.352 & 1.29 & 2.95 & 10.20 & 14.70 & 23.00 & 26.50 & 34.10 \\
\hline $\operatorname{san} .2$ & 0.0158 & 0.0765 & 0.113 & 0.117 & 0.291 & 1.13 & 1.02 & 3.05 & 5.07 & 6.69 & 7.99 & 8.09 \\
\hline San. 3 & 0.0362 & 0.0135 & 0.184 & 0.184 & 0.523 & 1.21 & 0.81 & 1.95 & 1.56 & 2.41 & 4.23 & 3.63 \\
\hline Avg. & 0.0256 & 0.0597 & 0.180 & 0.207 & 0.378 & 1.22 & 1.51 & 4.44 & 5.46 & 7.45 & 8.24 & 6.61 \\
\hline Uranium-238 & & & & & & & & & & & & \\
\hline Sen. 1 & 0.484 & 0.394 & 2.01 & 2.11 & 9.09 & 18.40 & 45.10 & 138.00 & 195.00 & 384.00 & 493.00 & 592.00 \\
\hline San. 2 & 0.254 & 0.576 & 2.74 & 1.10 & 1.39 & 14.10 & 15.50 & 51.90 & 105.00 & 158.00 & 151.00 & 167.00 \\
\hline San. 3 & 0.409 & 0.159 & 0.73 & 1.14 & 2.48 & 9.63 & 7.01 & 37.60 & 30.20 & 44.80 & 52.20 & 59.60 \\
\hline Avg. & 0.333 & 0.412 & 1.56 & 1.55 & 3.79 & 14.67 & 20.65 & 68.50 & 93.51 & 149.76 & 143.98 & 127.38 \\
\hline Cobalt t-60 & & & & & & & & & & & & \\
\hline Sam. 1 & 0.10 & 0.10 & 0.10 & 0.10 & 0.10 & 0.10 & 0.66 & 0.100 & 0.10 & 0.10 & 0.10 & 0.10 \\
\hline Sen. 2 & 0.10 & 0.10 & 0.10 & 0.10 & 0.10 & 0.10 & 0.10 & 0.599 & 0.10 & 0.10 & 0.10 & 0.10 \\
\hline Sam. 3 & 0.10 & 0.10 & 0.10 & 0.10 & 0.10 & 0.10 & 0.10 & 0.100 & 0.10 & 1.20 & 3.57 & 0.10 \\
\hline Avg. & 0.10 & 0.10 & 0.10 & 0.10 & 0.10 & 0.10 & 0.27 & 0.428 & 0.10 & 0.48 & 1.48 & 0.10 \\
\hline Cesium- 137 & & & & & & & & & & & & \\
\hline Sam. 1 & 0.10 & 0.104 & 0.16 & 0.10 & 0.10 & 0.10 & 0.742 & 0.100 & 0.10 & 0.10 & 0.10 & 0.10 \\
\hline San. 2 & 0.10 & 0.115 & 0.10 & 0.10 & 0.10 & 0.10 & 0.100 & 0.785 & 2.42 & 0.10 & 0.10 & 0.10 \\
\hline Sam. 3 & 0.10 & 0.100 & 0.10 & 0.10 & 0.10 & 0.10 & 1.440 & 0.100 & 0.10 & 2.07 & 0.10 & 0.10 \\
\hline Avg. & 0.10 & 0.106 & 0.12 & 0.10 & 0.10 & 0.10 & 0.879 & 0.550 & 1.18 & 0.79 & 0.10 & 0.10 \\
\hline
\end{tabular}


Table 1-3. 300-FF-1 North Pond Chemical Contaminants

by Size Fraction. (Serne et al. 1992)

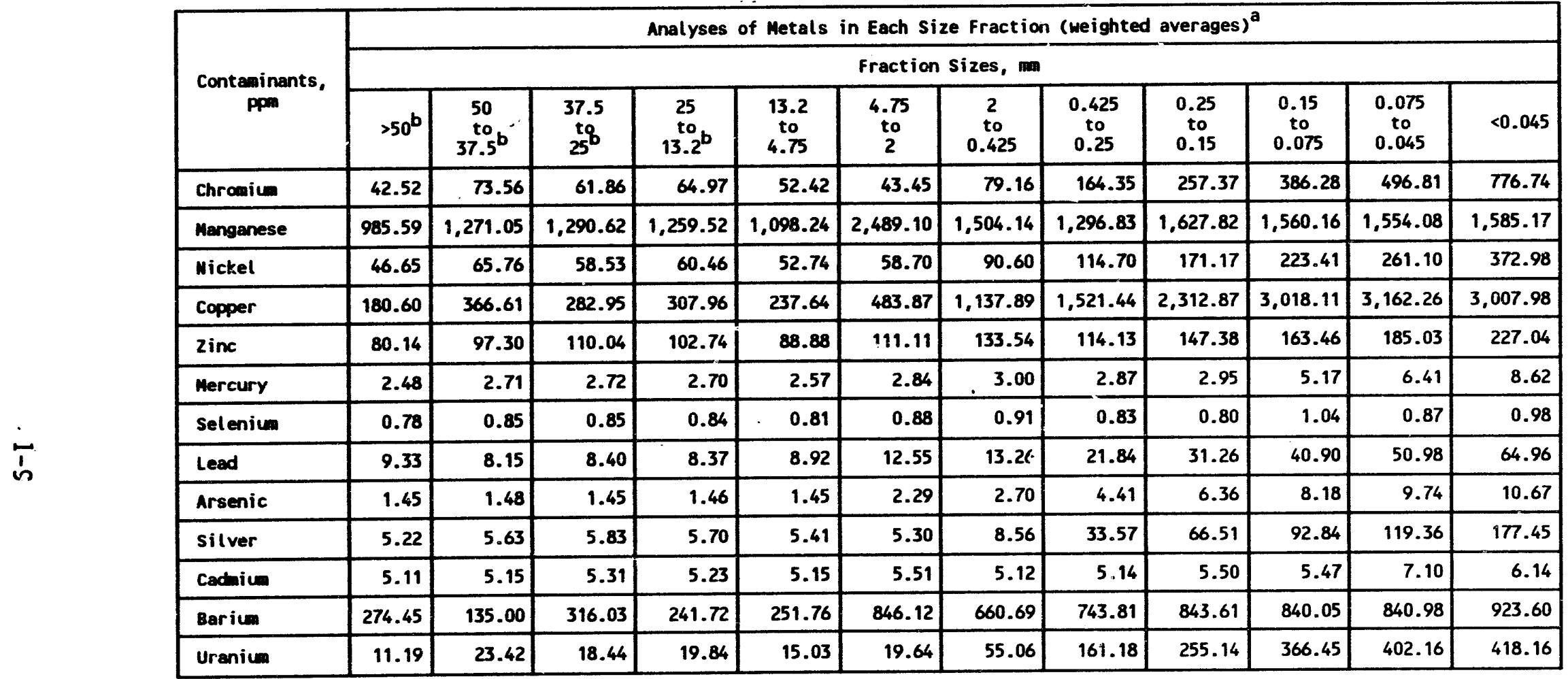

To simplify the table, only average values are shoun; for more details refer to Serne et al. 1992.

b the four largest size fractions yere not analyzed due to the size of the material. Values are assumed to equal that of the largest fraction analyzed (13.2 to 4.75) (Serne et al. 1992). 
Many physical separations systems are commercially available, but were not used because services and equipment could not be obtained in a timely manner to meet the Tri-Party Agreement milestone for the test. Therefore, a system was designed and assembled by WHC personnel (Figure 1-3) composed of modified EPA equipment and components available on the Hanford Site. The system was not designed for long-term use, or as a well-integrated system.

The system consisted of the following:

- 150-mm bar screen (grizzly) to separate out material >150 mm

- hopper and 25-mm vibrating screen with water sprays to separate material $>25 \mathrm{~mm}$

- belt conveyor to move <25-mm size particles from hopper to a trommel

- trommel with water knives to wash $>2-\mathrm{mm}$ soils and screen material $<2 \mathrm{~mm}$ in diameter

- second vibrating screen with a U.S. National Bureau of Standards $\# 40(0.425-\mathrm{mm})$ or $\# 70(0.212-\mathrm{mm})$ wire mesh screen to separate particles

- fractionation tanks to contain effluent and fines $<0.425 \mathrm{~mm}$ and serve as settling tanks

- off-line water treatment process

- fresh water supply tanks filled by truck

- B-25, low specific activity (LSA) boxes to contain <0.425-mm particles (per 49 CFR 173.403).

It is estimated that contaminated soil volumes in the 300 Area at Hanford could be reduced by $90 \%$ or more by separating coarse "clean" soils irom contaminated soils (Serne et al. 1992). The "clean fractions" that meet cleanup or release limits (to be determined by EPA and Ecology) would be returned to their original locations. Less than $10 \%$ of the soil residuals would require additional treatment/disposal. It is estimated that there are over $600,000 \mathrm{yd}^{3}$ of contaminated soils in the 300-FF-1 Operable Unit alone (DOE-RL 1993a). 
Figure 1-3. EPA Modified Physical Separation/Soil-Washing System.

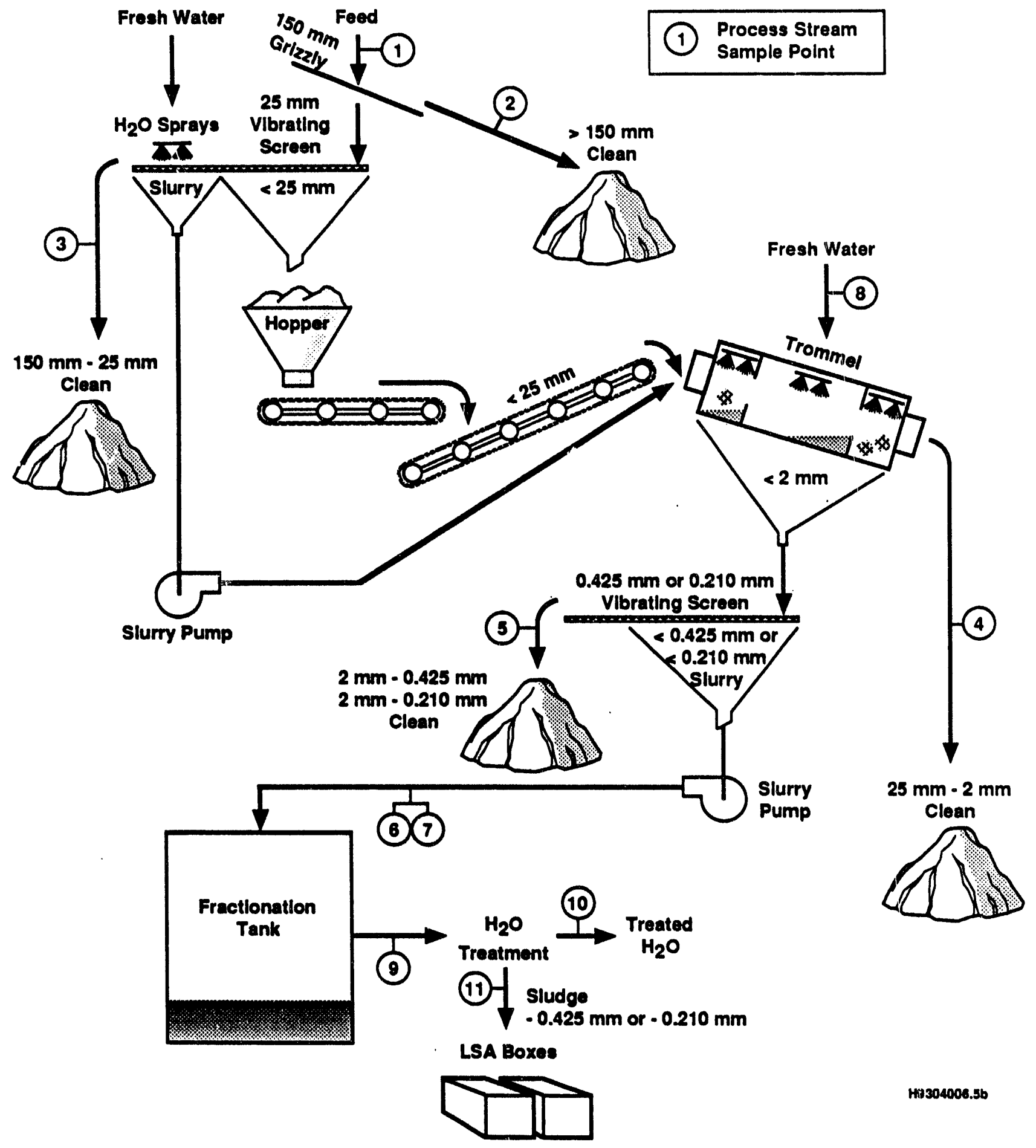


DOE/RL-93-96, Rev. 0

\subsection{TEST OBJECTIVES AND RATIONALE}

\subsection{OBJECTIVES}

The objective of these tests was to evaluate the use of water-based physical separations systems as a means of concentrating chemical and radiochemical contaminants into fine soil fractions and thereily minimizing the amount of contaminated soils.

To date, no specific applicable, relevant, or appropriate requirements (ARAR) have been established for radioactive soils in the 300-FF-1 Operable Unit at Hanford. Therefore, DOE orders and WHC control manual standards were used as minimum goals for the test. The only potential ARAR for soils that is chemical-specific is the Model Toxics Control Act (MTCA) (RCW 70.105D), but no cleanup levels have been established for soils in the 300-FF-1 Operable Unit at Hanford. Per agreement between DOE, Richland Operations (DOE-RL), EPA, and Ecology (documented in February 27, 1992, 300-FF-1 meeting minutes), MTCA, Method C, industrial levels were selected as test performance levels. The test performance levels established as a goal for the test and background levels for contaminants identified in the test plan (DOE-RL 1993b) are shown in Table 2-1. These contaminants were determined to include the primary risk drivers identified in Phase I RI (DOE-RL 1993C).

Minimum goals for the treatability test included:

- $90 \%$ or greater weight reduction of contaminated soils (based on Serne et a1. 1992).

- The clean fraction (90\%) must meet test performance levels shown in Table 2-1. Test performance levels are less than or equal to:

- $\quad<20 \mu \mathrm{R} / \mathrm{hr}$ above background radioactivity (DOE 1990)

- The Residual Radioactivity (RESRAD) Program, Version 4.0, <25 mrem/hr (Gilbert et al. 1989).

- WHC radioactive threshold concentrations for accessible soils (WHC 1991)

- MTCA, Method C, industrial levels.

- These test performance levels should not be considered as cleanup levels, which are yet to be established for Hanford soils.

- Perform analyses consistent with applicable EPA methods (EPA 1990) and test $p l a n$ requirements. 
Table 2-1. Background Levels of Contaminants and Test Performance Levels for Soil Treatability Tests.

\begin{tabular}{|c|c|c|c|}
\hline Analyte & Units & $\begin{array}{l}\text { Background } \\
\text { Levels s }\end{array}$ & $\begin{array}{l}\text { Test } \\
\text { Performance } \\
\text { Levels }\end{array}$ \\
\hline $\begin{array}{l}\text { Metals (inorganics) } \\
\text { Aluminum } \\
\text { Antimony } \\
\text { Arsenic } \\
\text { Beryllium } \\
\text { Cadmium } \\
\text { Chromium } \\
\text { Copper } \\
\text { Iron } \\
\text { Lead } \\
\text { Manganese } \\
\text { Mercury } \\
\text { Nickel } \\
\text { Silver } \\
\text { Zinc }\end{array}$ & $\mathrm{mg} / \mathrm{kg}$ & $\begin{array}{c}3,070 \\
5.01 \\
0.59 \\
0.25 \\
0.59 \\
5.0 \\
10.7 \\
11,300 \\
1.55 \\
189 \\
0.049 \\
3.8 \\
1.53 \\
11.5\end{array}$ & $\begin{array}{r}N A \\
1,400 \\
188 \\
31 \\
1,750 \\
3,200,000 \\
130,000 \\
N A \\
N A \\
17,500 \\
1,050 \\
70,000 \\
10,500 \\
1,050,000\end{array}$ \\
\hline Organics & $\mathrm{mg} / \mathrm{kg}$ & & \\
\hline $\begin{array}{l}\text { 1,2-dichloroethylene } \\
\text { Methylene chloride } \\
\text { Tetrachloroethylene } \\
\text { Trichloroethylene }\end{array}$ & & $\begin{array}{l}0 \\
0 \\
0 \\
0\end{array}$ & $\begin{array}{r}35,000 \\
17,500 \\
2,570 \\
11,900\end{array}$ \\
\hline $\begin{array}{l}\text { PCB } \\
\frac{\text { Radiochemical }}{\text { Contaminants }}\end{array}$ & $\begin{array}{l}\mathrm{mg} / \mathrm{kg} \\
(\mathrm{ppm}) \\
\mathrm{pCi} / \mathrm{g}\end{array}$ & 0 & 17 \\
\hline $\begin{array}{l}\text { Cestum-137 } \\
\text { Cobalt-60 } \\
\text { Uranium-235 } \\
\text { Uranium-238 }\end{array}$ & & $\begin{array}{l}0 \\
0 \\
0 \\
0\end{array}$ & $\begin{array}{l}30 \\
7.1 \\
170 \\
370\end{array}$ \\
\hline
\end{tabular}

Test performance levels for inorganic and organic contaminants are MTCA, Method C, industrial levels (Ecology 1993).

bTest performance levels for radionuclides are from WHC (1991).

'Background levels are values used for risk calculations from Phase I RI report (DOE-RL 1993C). A value of " $O$ " was used for risk assessments for all organics, PCBs, and radionuclides. 
Water treatment was a secondary objective for the test. The primary goal of water treatment tests was to treat processed effluent to meet purgewater acceptance standards (Appendix A) so that water can be recycled in a full-scale system, and process water generated during the tests can be handled as purgewater (DOE-RL 1993b). The reason for selecting purgewater standards as test performance levels for treated water was that these levels were required by WHC personnel to discharge treated water to solar evaporation units onsite. The purgewater acceptance levels were also a reasonable and convenient criteria to recycle and reuse water in the soil treatment process. Purgewater acceptance standards are mostly 10 times drinking water criteria (maximum contaminant levels [MCL]) (WHC 1991). There is no regulatory requirement for selecting this as a test performance level.

\subsection{POTENTIAL ARARS}

Table 2-2 lists potential chemical-, location-, and action-specific ARARs to the soil treatability test. A final set of ARARs will be identified in the 300-FF-1 Operable Unit Phase. III FS to be written at a later date.

\subsection{DATA QUALITY OBJECTIVES}

The primary sampling and analysis data quality objectives (DQO) were to:

- determine physical characteristics of soils

- determine the distribution and concentration of contaminants in the soils before and after a physical separation is made between the coarse material and the fine material

- evaluate separation efficiencies in relation to process parameters

- after processing, determine the concentration of contaminants of concern in the process water, both suspended and dissolved, and evaluate the effectiveness of water treatment methods

- obtain samples and analytical results of sufficient quality to document performance of the system or systems tested and determine if cleanup criteria can be met.

Samples collected during the test were analyzed using: EPA methods (EPA 1990), approved radioanalytical procedures, and the American Society for Testing and Materials (ASTM) procedures for measuring physical parameters. This meets EPA Level III DQO. Additional DQO for this test are defined in the 300-FF-1 Operable Unit work plan (DOE-RL 1990). 
Table 2-2. Potential ARARs for the Soil Treatability Test. (Sheet 1 of 2)

\begin{tabular}{|c|c|c|}
\hline Regulation & Citation & Applicability \\
\hline \multicolumn{3}{|l|}{ FEDERAL } \\
\hline Safe Drinking Water Act & 40 CFR 141 & $\begin{array}{l}\text { Potentially Relevant } \\
\text { and Appropriate }\end{array}$ \\
\hline $\begin{array}{l}\text { Federal Water Pollucion Control } \\
\text { Act (FUPCA), as amended by the } \\
\text { Clean Water Act of } 1977\end{array}$ & 33 usc 1251 et seq. & $\begin{array}{l}\text { Potentially Relevant } \\
\text { and Appropriate }\end{array}$ \\
\hline Wild and Scenic Rivers & PL $100-605$ & Applicable \\
\hline Clean Air Act & 42 USC 7401 et seq. & Appl icable \\
\hline $\begin{array}{l}\text { National Ambient Air Quality } \\
\text { Standards }\end{array}$ & 40 CFR 50 & Applicable \\
\hline $\begin{array}{l}\text { National Emissions Standards } \\
\text { for Hazardous Air Pollutants }\end{array}$ & 40 CFR 61 & Appl icable \\
\hline $\begin{array}{l}\text { New Sources Performance } \\
\text { Standards }\end{array}$ & 40 CFR 60 & $\begin{array}{l}\text { Potentially Relevant } \\
\text { and Appropriate }\end{array}$ \\
\hline Toxic Substances Control Act & 15 usc 2601 et seq. & $\begin{array}{l}\text { Potentially Relevant } \\
\text { and Appropriate }\end{array}$ \\
\hline PCB Restrictions & 40 CFR 761 & $\begin{array}{l}\text { Potentially Relevant } \\
\text { and Appropriate }\end{array}$ \\
\hline Atomic Energy Act & 42 usc 2011 et seq. & $\begin{array}{l}\text { Potentially Relevant } \\
\text { and Appropriate }\end{array}$ \\
\hline $\begin{array}{l}\text { The Uranium Mill Tailings } \\
\text { Control Act of } 1978\end{array}$ & PL 95-604, as amended & $\begin{array}{l}\text { Potentially Relevant } \\
\text { and Appropriate }\end{array}$ \\
\hline $\begin{array}{l}\text { Envirommental Standarda for } \\
\text { Management, Storage and } \\
\text { Disposal of Low Level } \\
\text { Radioactive Waste }\end{array}$ & 40 CFR 193 & Applicable \\
\hline $\begin{array}{l}\text { Radiation Protection of the } \\
\text { Public and the Enviromment }\end{array}$ & DOE Order 5400.5 & To Be Considered \\
\hline Radi oact ive Waste Management & DOE Order $5820.2 \mathrm{~A}$ & To Be Considered \\
\hline $\begin{array}{l}\text { Safety Requirements for the } \\
\text { Packaging of Fissile and Other } \\
\text { Radioactive Materials }\end{array}$ & DOE Order 5480.3 & To Be Considered \\
\hline $\begin{array}{l}\text { Rediation Protection for } \\
\text { Occupational Workers }\end{array}$ & DOE Order 5480.11 & To Be Considered \\
\hline $\begin{array}{l}\text { National Historic Preservation } \\
\text { Act }\end{array}$ & 16 USC 470 et seq. & Applicable \\
\hline Endengered Species Act & 16 USC 1531 ot seq. & $\begin{array}{l}\text { Potentially Relevant } \\
\text { and Appropriate }\end{array}$ \\
\hline $\begin{array}{l}\text { Sol id Waste Disposal Act as } \\
\text { amended by the Resource } \\
\text { Conservation and Recovery } \\
\text { Act (RCRA) }\end{array}$ & 42 USC 6901 et seq. & Applicable \\
\hline \multicolumn{3}{|l|}{ STATE } \\
\hline Dangerous Waste Regulations & Ch. 173-303 WAC & Applicable \\
\hline MTCA Cleanup Regulations & Ch. 173-340 WAC & Appl Icable \\
\hline $\begin{array}{l}\text { Minimm Functional Standards } \\
\text { for Sol id Waste Handling }\end{array}$ & Ch. 173-304 WAC & Appl icable \\
\hline Water Pollution Control & Ch. $90.48 \mathrm{RCW}$ & Appl icable \\
\hline $\begin{array}{l}\text { State Waste Discharge Permit } \\
\text { Program }\end{array}$ & Ch. 173-216 WAC & Appl icable \\
\hline
\end{tabular}


Table 2-2. Potential ARARs for the Soil Treatability Test. (Sheet 2 of 2)

\begin{tabular}{|c|c|c|}
\hline Regulation & Citation & Applicability \\
\hline \multicolumn{3}{|l|}{ STATE ${ }^{\mathrm{a}}$ (Cont.) } \\
\hline $\begin{array}{l}\text { Water Quality Standards for } \\
\text { the state of Washington }\end{array}$ & Ch. 173-201 WAC & Appl icable \\
\hline $\begin{array}{l}\text { Ambient Air quacity Standards } \\
\text { and Emission Limits for } \\
\text { Radionuclidas }\end{array}$ & Ch. $173-480$ WAC & Appl icable \\
\hline $\begin{array}{l}\text { Radiation Protection - Air } \\
\text { Emissions }\end{array}$ & Ch. 246-247 WAC & Appl icable \\
\hline Toxic Air Pollutants & Ch. $173-460$ WAC & Applicable \\
\hline Washington Clean Air Act & $\mathrm{Ch} .70 .94 \mathrm{RCW}$ & Applicable \\
\hline
\end{tabular}

As proposed by Ecology.

The primary data users include:

- DOE, EPA, and Ecology remedial project managers

- DOE, EPA and Ecology unit managers

- RI and FS coordinators

- technical contributors.

Data will be used to support final remediation decisions in FS. Evaluations and decisions will include the following categories:

- site characterization

- occupational health and safety

- risk assessments

- evaluating alternatives

- design of alternatives

- monitoring during remedial actions.

The following questions were answered by the treatability tests. (applicable sections that address these areas are in parentheses):

1. Are agglomerates completely dispersed during processing? If not, what means are necessary to separate agglomerated material adequately? (Sections 6.4 and 7.2 )

2. Are the coarse fractions cleanly separated from the fines? (Sections 6.2.1 and 7.2.1)

3. What, if any, treatment is required for large materials? (Sections 6.1 and 7.1 )

4. What are the operating costs (Section 14.0) 
5. To what extent do soluble contaminants build up in the recycle water? (This is key to determining what water treatment will be required for internal water recycle streams and for the reject water stream.) (Sections 6.2, 7.2 and 8.0)

6. How much will it cost to purchase and operate a full-scale $(>100 \mathrm{t} / \mathrm{hr}$ ) plant? (Sections 14.0 and 15.0)

7. As a preliminary assessment only, is there any possibility that indicator analytes, such as uranium-238, uranium-235, and/or specific inorganic constituents could be used during final remediation to verify cleanup standards are met, thus eliminating the need and cost to analyze for all contaminants of concern? (Section 15.0) 
DOE/RL-93-96, Rev. 0

\subsection{EQUIPMENT AND MATERIALS}

The following equipment was required for the tests:

- soil washing system

- one $1-\mathrm{m}^{3}$ hopper (from EPA) modified to include 150-mm grizzly

- one 5-m hopper and feed conveyor

- two belt conveyors (one from EPA)

- 25-mm vibrating screen

- Kinergy secondary vibrating screen (from EPA)

- two \#40 (0.425-mm) and two \#60 (0.210-mm) screens

- $\quad 1.37-\mathrm{m}$ dia. by $6.4-\mathrm{m}$ long trailer-mounted tromme? (from EPA)

- generator (from EPA)

- three 75,000-L fractionation tanks

- two plastic water tanks 24,600 L, and 34,000 L (from EPA)

- one 6-kW gasoline pump

- miscellaneous hoses and connections

- water truck

- backhoe

- front-end loader

- field/hand-held radiation monitoring instruments

- anticontamination clothing (anti-C's)

- miscellaneous tools

- sampling containers and equipment

- change trailer

- dust monitoring instruments

- wind and temperature gages

- first aid/safety equipment

- radios/cellular phone

- logbook. 


\subsection{SAMPLING AND ANALYSIS}

The following samples and analyses were performed for Test \#1 and Test \#2. Samples were collected in accordance with the test plan (DOE-RL 1993b) and the work plan (DOE-RL 1990, FSP and QAPP). Sample numbers and locations for each of the tests are shown in Tables 4-1 and 4-2.

\subsection{PRE-PROCESS SAMPLES}

Prior to processing, a clean process water sample was taken from clean water holding tanks. This sample received chemical and radiochemical analysis to establish initial conditions for the water.

Table 4-1. Samples and Hanford Environmental Information System (HEIS) Numbers for Test \#1.

\begin{tabular}{|c|c|c|c|}
\hline $\begin{array}{l}\text { Strean Munber, } \\
\text { Material Size, } \\
\text { Sample Period }\end{array}$ & $\begin{array}{c}\text { Laboratory Analysis } \\
\text { Chemical and Radiological } \\
\text { (Offsite) }\end{array}$ & $\begin{array}{l}\text { Physical Analysis } \\
\text { XRF \& Gamma } \\
\text { Spectrometry } \\
\text { (Onsite) }\end{array}$ & $\begin{array}{l}\text { TCLP } \\
\text { Analysis } \\
\text { (Offsite) }\end{array}$ \\
\hline $\begin{array}{l}\text { Stream "1, Raw Feed, } \\
\text { Processing }\end{array}$ & $\begin{array}{l}\text { 807C09, B07C10, } 807 C 11,807 C 67 \text { (d)p to } \\
\text { B07C11), B07C38, 807C39, B07C40 }\end{array}$ & BO8MN6, BOBNM2 & \\
\hline $\begin{array}{l}\text { Strean } 12, \text { Plus } 150 \mathrm{~mm}, \\
\text { Post-Process }\end{array}$ & & B08mN8 ${ }^{a}$, BOBNM4 $^{a}$ & \\
\hline $\begin{array}{l}\text { Strean } 13,150 \text { to } 25 \mathrm{~mm}, \\
\text { Post-Process }\end{array}$ & & BO8*An9, B08MM5 & \\
\hline $\begin{array}{l}\text { Stream } 25 \text { to } 2 \text { min, } \\
\text { Post-Process }\end{array}$ & 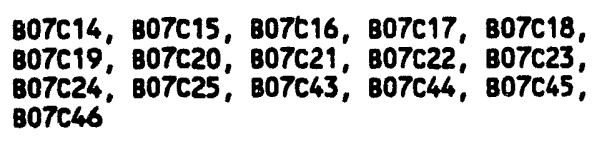 & $\begin{array}{l}\text { BO8MPO, B08NM6, } \\
\text { B08NM8 }\end{array}$ & \\
\hline $\begin{array}{l}\text { Streem } 15,2 \text { to } 0.425 \mathrm{~mm}, \\
\text { Fost-Process }\end{array}$ & 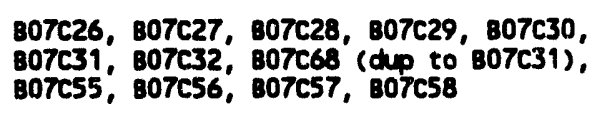 & $\begin{array}{l}\text { Bosip1, B08NM7, } \\
\text { Bosmis }\end{array}$ & \\
\hline $\begin{array}{l}\text { stream } 16, \text { Minus } 0.425-m \\
\text { slurry Water, Processing }\end{array}$ & $\begin{array}{l}\text { 807C75, B07C76, 807C77, } 807 \mathrm{C85} \text { (d)p to } \\
\text { B07C76), 807C79, 807C80, 807C81 }\end{array}$ & & \\
\hline $\begin{array}{l}\text { stream } 77 \text {, Minus } 0.425-m \\
\text { slurry Soils, Processing }\end{array}$ & $\begin{array}{l}\text { 807C91, 807C92, s07c93, 807c95, s07c96, } \\
\text { B07C97, B07CB1 (dup to B07C97), }\end{array}$ & 808мnบ7, В08NM3 & $\begin{array}{l}\text { BOENNO, } \\
\text { BOBNL6 }\end{array}$ \\
\hline $\begin{array}{l}\text { Strean } 16, \text { Fresh Water, } \\
\text { Pre-Process }\end{array}$ & $\begin{array}{l}807 C 70,807 C 73 \text { (trip blank), B08mis, } \\
\text { 807C71, B07C72 (dep to 807C71), B08inL4 }\end{array}$ & & \\
\hline Trip Blanks & B07C74, 807C87, 807C82, 807CB3 & & \\
\hline
\end{tabular}

analysis of only fine soils washed off the rocks. >150-m material was not analyzed. 
Table 4-2. Samples and HEIS Numbers for Test \#2.

\begin{tabular}{|c|c|c|c|}
\hline $\begin{array}{l}\text { Stream Number, } \\
\text { Material size, } \\
\text { Sample period }\end{array}$ & $\begin{array}{c}\text { Laboratory Analysis } \\
\text { Chemical and Radiological } \\
\text { (Offsite) }\end{array}$ & $\begin{array}{l}\text { Physical Analysis } \\
\text { XRF \& Gamma } \\
\text { Spectrometry } \\
\text { (Onsite) }\end{array}$ & $\begin{array}{l}\text { TCLP Analysis } \\
\text { (Offsite) }\end{array}$ \\
\hline $\begin{array}{l}\text { Stream \#1, Raw Feed, } \\
\text { Processing }\end{array}$ & $\begin{array}{l}\text { BOTOP9, 807000, B070Q1, B07DQ2, } \\
\text { BOTDQ3 }\end{array}$ & B09758 & \\
\hline \multicolumn{4}{|l|}{$\begin{array}{l}\text { Strean } 2 \text {, Plus } 150 \mathrm{~mm}, \\
\text { Post-Process }\end{array}$} \\
\hline $\begin{array}{l}\text { Stream } \$ 3,150 \text { to } 25 \mathrm{~mm}, \\
\text { Post-Process }\end{array}$ & & B09761 & \\
\hline $\begin{array}{l}\text { Stream } \approx 4,25 \text { to } 2 \mathrm{~mm}, \\
\text { Post-Process }\end{array}$ & 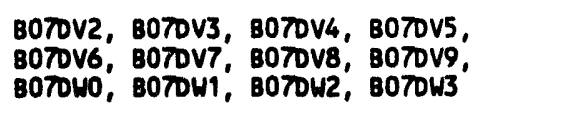 & B09762 & \\
\hline $\begin{array}{l}\text { Stream } 15,2 \text { to } 0.425 \mathrm{~mm}, \\
\text { Post-Process }\end{array}$ & 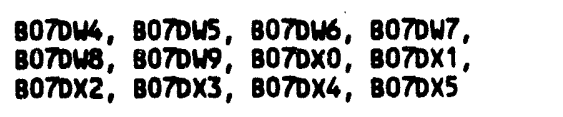 & 809763 & \\
\hline $\begin{array}{l}\text { Streem } 16, \text { Minus } 0.425-m \\
\text { slurry Water, Processing } \\
\end{array}$ & 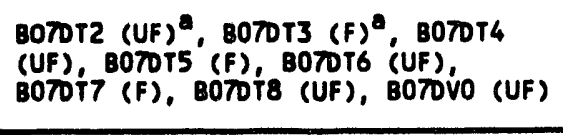 & 809760 & \\
\hline $\begin{array}{l}\text { strean }: 77 \text {, Minus } 0.425-m m \\
\text { slurry soils, Processing }\end{array}$ & BoT0s7, в070s8, в070s9 & 809759 & $\begin{array}{l}809757 \text { (split } \\
\text { to } 807059)\end{array}$ \\
\hline $\begin{array}{l}\text { Stream } 16, \text { Fresh Water, } \\
\text { Pre-Process }\end{array}$ & $\begin{array}{l}\text { B07004, 8070X8 (dep to B07004), } \\
\text { B07005, B070X9 (dup to B07005) }\end{array}$ & & \\
\hline Trip Blanks & $\begin{array}{l}\text { Bo70Y5, B070Y6 } \\
\text { BO7DYo, B070Y1 }\end{array}$ & & \\
\hline
\end{tabular}

QuF $=$ unfiltered; $F=f i l$ tered with a $0.2 \cdot \mu m$ filter.

\subsection{PROCESS SAMPLES}

During processing, the feed material stream and the final process slurry stream were sampled. The first effluent sampling event occurred after the material appeared at the sampling point described in this section. The final sample was collected just, prior to completion of processing. Process soil and effluent samples taken included the raw feed soils, slurry water, and slurry soils shown in Tables 4-1 and 4-2.

Samples volumes and types were as follows:

- $\quad 500-\mathrm{mL}$ samples of the feed soils were sent offsite for chemical and radiochemical analysis.

- $\quad 3,500-\mathrm{mL}$ samples of the feed soils received onsite screening analysis. A sub-sample was composited, weighed, dried, and weighed again to determine moisture content. The remaining sample was wet-sieved. Individual size fractions were analyzed for metals and radionuclides. 
- 3,500-mL samples of the process effluent with suspended solids were sent offsite. Samples were taken at a minimum after every hour of continuous processing throughout the processing period. Effluent samples for Test \#1 were not filtered by the laboratory. In Test \#2, effluent samples were filtered in the field using a $0.2-\mu \mathrm{m}$ filter prior to being sent to the laboratory for analysis. Solids in the effluent were analyzed separately for both tests.

- 3,500-mL samples of the process effluent with suspended solids were sent to onsite laboratories for analytical screening. Solids were then filtered from the effluent using a $0.45-\mu \mathrm{m}$ membrane. The solids from the composite were wet-sieved, and each fraction was weighed. Individual fractions were mixed with size separates from post-process samples to provide enough material for adequate analysis and to reduce the number of analyses that were required (It was assumed that mineralogical and contaminant characteristics would be the same for particles of the same size fraction in each of the process and post-process samples.) Each of these fractions was analyzed for chemical and radiochemical constituents. Filtered effluent was analyzed by inductively coupled plasma (ICP) and by ICP/mass spectrometry (MS) to get measurements of major cations.

- 2,000-mL samples of the process effluent and suspended solids. were sent to an offsite laboratory for TCLP analysis. A 0.6- to 0.8- $\mu \mathrm{m}$ borosilicate glass fiber filter (EPA 1990, method 1311) was used in the TCLP analysis.

\subsection{POST-PROCESS SAMPLES}

After processing, samples were taken from random locations in each process pile. This is described in the following paragraphs. Post-process samples taken are shown in Tables 4-1 and 4-2.

\subsection{1 >150-nm Material}

One 22-L (5-gal) sample for Test \#1 was sent to an onsite laboratory where fine soils were washed off the rock. The rocks and soils were then dried and weighed to show the size distribution of soils and rocks screened by the 150-mm grizzly. Rinsate was collected in a carboy, then wet-sieved, dried, weighed, and mixed with similar sized material from other process piles. As for effluent process samples, individual fractions were mixed with size separates from other process and post-process samples to provide enough material for adequate analysis. Fine soils were analyzed for metals and radionuclides. Rocks were not analyzed.

\subsubsection{0- to 25- $\mathrm{mm}$ Material}

Samples were sent to an onsite laboratory for analysis. The samples were composited to make up $22 \mathrm{~L}(5 \mathrm{gal})$ of material. The composited material was weighed and wet-sieved. Each fraction was then dried, weighed, and mixed with similar sized material from other process piles and analyzed for metals ( $9.5 \mathrm{~mm}$ and smaller) and radionuclides. 


\subsubsection{5- to 2-mm Material}

Two 300-mL samples were taken from each of 16 locations. One sample from each location was sent to an onsite laboratory. Onsite samples were composited, weighed, and wet-sieved. Each fraction was then dried, weighed, and mixed with similar sized material from other process piles and analyzed for metals $(9.5 \mathrm{~mm}$ and smaller) and radionuclides. The other 16 samples were sent offsite for chemical and radiochemical analysis.

\subsubsection{2- to 0.425- $\mathrm{mm}$ Material}

Two 300-mL samples were taken from each of 16 locations. One sample from each location was sent to an onsite laboratory for analytical screening. Samples were composited, weighed, and wet-sieved. Each fraction was then dried, weighed, and mixed with similar sized material from other process piles and analyzed for metals $(9.5 \mathrm{~mm}$ and smaller) and radionuclides. The other 16 samples were sent offsite for chemical and radiochemical analysis.

\subsection{5 $<0.425-\mathrm{mm}$ Material}

All samples of this material were taken during processing (see Section 4.2).

\subsection{AMALYSES AMD VALIDATION}

EPA analytical Level III and Level $V$ analyses (EPA 1990) were performed by offsite laboratories in accordance with the test plan. Samples were analyzed for metals using EPA methods, for total uranium using fluorimetry, and for other radionuclides using gamma spectrometry. Water samples were analyzed for these constituents and volatile organic compounds VOC) using the EPA methods (1990).

Per agreement between DOE-RL, EPA, and Ecology documented in March 4, 1993 meeting minutes, all offsite sample analyses except TCLP were validated using WHC Level 3 Resource Conservation and Recovery Act (RCRA) data validation procedures (WHC 1990). Review requirements included:

- requested versus reported analyses

- analyses holding times

- matrix spike/matrix spike duplicate analysis

- surrogate recoveries

- duplicate analysis

- analytical blank analysis:

Samples sent to onsite laboratories were sieved and analyzed by size fraction using EPA Level II. The following sieve sizes (mm) were used: 25, $13.2,9.5,2,1,0.425,0.212,0.150$, and 0.075 . After being wet-sieved and air-dried, each size fraction was analyzed for metals using $x$-ray fluorescence (XRF) and for radionuclides using gamma spectrometry. Additional discussion of onsite sample analyses is provided by Serne et al. (1993). 


\subsection{PRE-TEST}

The pre-test was conducted in a clean, uncontaminated area located approximately $3.2 \mathrm{~km}$ northwest of the 300-FF-1 Operable Unit (see Figure 1-1). The pre-test was a "shakedown run" of the physical separations prototype system. The pre-test was conducted to prepare the system for Test \#1 and Test \#2 by making adjustments, repairs, modifications, and screen changes, and to familiarize operators with the system. Table 5-1 summarizes the processing activities for the pre-test.

Table 5-1. Summary of Pre-test Processing Activities.

\begin{tabular}{|c|c|c|c|}
\hline Date & Processed & Material & $\begin{array}{c}\text { Processing Time } \\
\text { (approx.) }\end{array}$ \\
\hline $05 / 28 / 93$ (a.m.) & 1.7 tons & Uncontaminated soils & $60 \mathrm{~min}$ \\
\hline $05 / 28 / 93$ (p.m.) & 1.7 tons & Uncontaminated soils & $15 \mathrm{~min}$ \\
\hline $06 / 01 / 93$ (a.m.) & 11.9 tons & Uncontaminated soils & $68 \mathrm{~min}$ \\
\hline $06 / 01 / 93$ (p.m.) & 11.9 tons & Uncontaminated soils & $56 \mathrm{~min}$ \\
\hline $06 / 02 / 93$ (a.m.) & 7.7 tons & Uncontaminated soils & $48 \mathrm{~min}$ \\
\hline $06 / 02 / 93$ (p.m.) & 4.6 tons & Uncontaminated soils & $22 \mathrm{~min}$ \\
\hline $06 / 02 / 93$ (p.m.) & 6.6 tons & Uncontaminated soils & $30 \mathrm{~min}$ \\
\hline
\end{tabular}

Approximately 46 tons of uncontaminated soil was processed during the test conducted May 28 to June 2, 1993. Material processed was excavated from uncontaminated soils stockpiled at the pretest site. Soils were removed from the stockpile and trickled from a $1-\mathrm{m}^{3}$ backhoe bucket onto a $150-\mathrm{mm}$ grizzly. Two spray nozzles were mounted at the end of the $25-\mathrm{mm}$ vibrating screen to spray rocks 150 to $25 \mathrm{~mm}$ to remove fine soil particles. Effluent coming off these sprays was discharged to a nearby trench. Soil particles <25 $\mathrm{mm}$ in diameter were conveyed to the trommel where they were separated by a 2-mm wire mesh screen. Particles 25 to $2 \mathrm{~mm}$ in diameter were sprayed, soaked, and rinsed in the tromme1, then stockpiled. Particles $<2 \mathrm{~mm}$ were sprayed and passed through the screen in the trommel, then transferred from the trommel to a second vibrating screen. Both a US $\# 40(0.425-\mathrm{mm})$ and US \#70 $(0.212-\mathrm{mm})$ screen were tested on the secondary vibrating screen. Soil fines and slurry passing through the screen were discharged at a rate of about $380 \mathrm{~L} / \mathrm{min}$ to a series of cascading water tanks.

Water used during the pre-test was tap water trucked to the site and pumped into two clean plastic holding tanks. Dust was controlled by spraying the stockpile with water before excavating. Modifications were made during the testing period to reduce water splash and enhance dust control.

Processed soil piles were flattened out and blended into the surrounding landscape after the pre-test was completed. 
Random samples were taken to estimate or measure physical properties such ias approximate flow rates, percent solids, percent moisture, and degree of separation. Dry sieving in the laboratory of soils separated by the system during this test indicated $96 \%$ by weight of 25 - to $0.212-\mathrm{mm}$ fraction of soils was $>0.212 \mathrm{~mm}$. Based on these results, equipment settings were selected to achieve the best size separation at an acceptable throughput rate. These are the baseline operating parameters used for Test \#1 and Test \#2.

An added benefit of the pre-test was the opportunity for close observation by WHC and RL management of the system in operation. This was not possible during Test \#1 and Test \#2 because these tests were conducted in a surface contamination area where the closest observation point was over $50 \mathrm{~m}$ from the system.

A more detailed description of the pre-test including operation, measurements, and sampling is provided by McGuire (1993). In general, the objectives of the pre-test were met. Operators gained experience operating the soil-washing system, operating parameters were established, system repairs were made, and the system was readied for the tests with contaminated soils. 


\subsection{TEST \#1}

This test was conducted in the north process pond between June 23 and June 29, 1993. The purpose was to establish the performance of the system. Initial plans were to process 40 tons of soil; however, less material was processed due to unexpected test complications and results explained later in this section. Table 6-1 summarizes the processing activities for Test \#1.

Table 6-1. Summary of Test \#1 Activities.

\begin{tabular}{|l|l|l|l|}
\hline \multicolumn{1}{|c|}{ Date } & Processed & \multicolumn{1}{|c|}{ Material } & \multicolumn{1}{|c|}{ Processing Time } \\
\hline $06 / 23 / 93$ & 10 tons & $\begin{array}{l}\text { Soils contaminated } \\
\text { with green and } \\
\text { white particles }\end{array}$ & $\begin{array}{l}\text { Approximately } 30 \text { min for } \\
\text { backhoe to dump and } 76 \text { min } \\
\text { processing }\end{array}$ \\
\hline $\begin{array}{c}06 / 24-25 / 93 \\
\text { (combined) }\end{array}$ & 7.0 tons & $\begin{array}{l}\text { Soils contaminated } \\
\text { with green and } \\
\text { white particles }\end{array}$ & $\begin{array}{l}\text { Approximately } 20 \text { min for } \\
\text { backhoe to dump and } \\
169 \text { min processing }\end{array}$ \\
\hline $06 / 29 / 93$ & 0.5 ton & $\begin{array}{l}\text { Soils contaminated } \\
\text { with green and } \\
\text { white particles }\end{array}$ & $\begin{array}{l}\text { Approximately } 70 \text { min } \\
\text { processing }\end{array}$ \\
\hline
\end{tabular}

Two things need to be pointed out about Table 6-1: (1) the material processed was not the type of material that was proposed for the test; and (2) the processing times shown in Table 6-1 are broken down to show the amount of time spent dumping by the backhoe and the amount of time actually processing. This was necessary for Test \#1 because the process was not continuous.

Figure 6-1 shows the system configuration and the material balance for Test \#1. The operating parameters and flow measurements for Test \#1 are shown in Table 6-2.

A $0.425-\mathrm{mm}$ screen size was selected for the secondary screen, the final screening step, to separate contaminated and clean material. Based on data in Tables 1-1, 1-2, and 1-3, this cut point was selected to meet the test goal to reduce the amount of contaminated material by $90 \%$ (by weight). The size of the primary screen was dictated by the design capabilities of the tromme 1 (i.e., feed material of $25 \mathrm{~mm}$ or less) and the flows were initially set to conform to the designed operating levels of the trommel and by experience gained during the pre-test shakedown. Adjustments were made during the test. 
DOE/RL-93-96, Rev. 0

Figure 6-1. System Configuration/Material Balance for Test \#1.

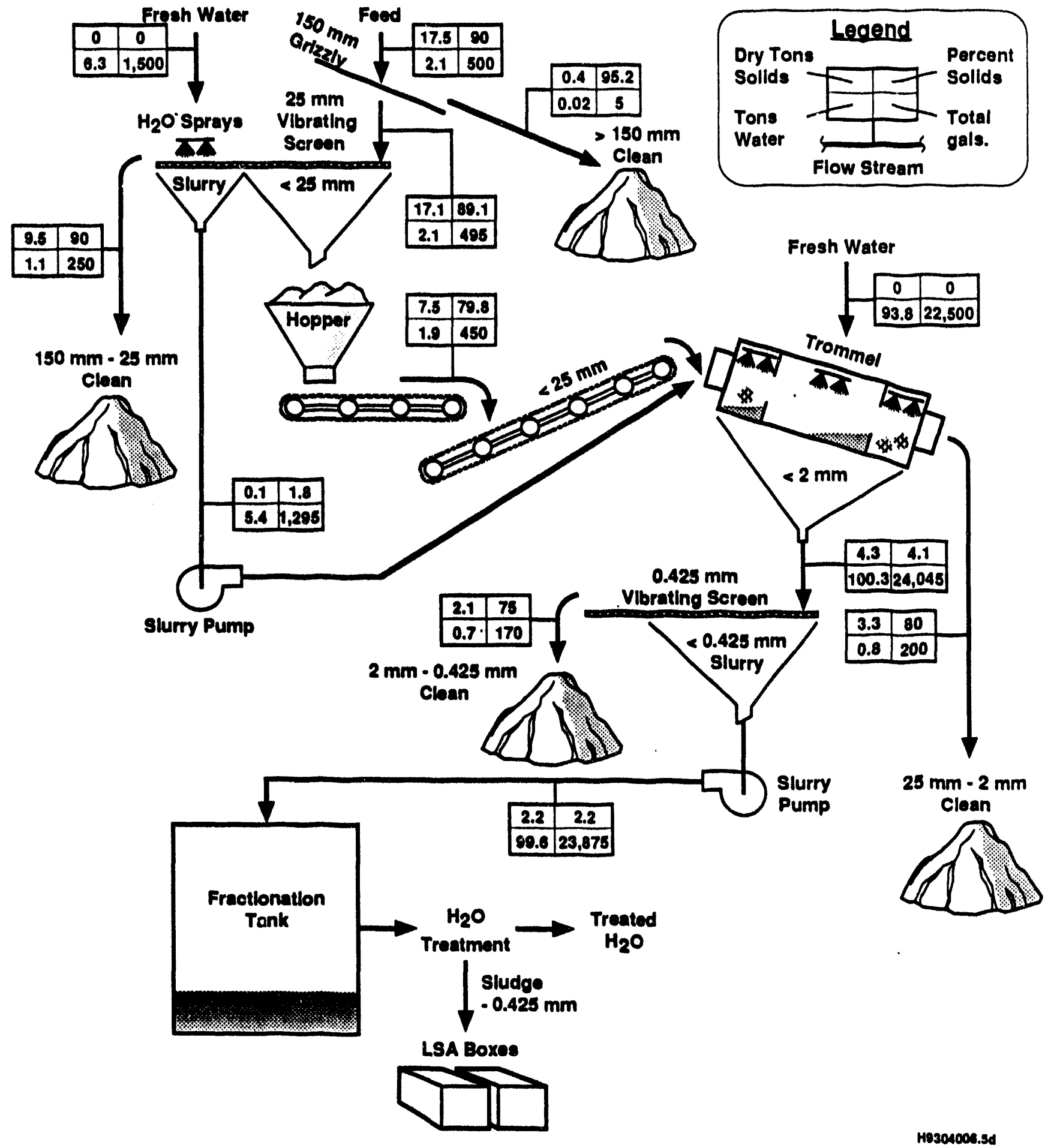

Hoso400.sd 
Table 6-2. Equipment Operating Parameters and Flow Measurements for Test \#1.

\begin{tabular}{|c|c|c|c|c|c|}
\hline Component & \multicolumn{2}{|c|}{ Parameter } & $\begin{array}{l}\text { June } 23 \\
\text { Processing }\end{array}$ & $\begin{array}{l}\text { June } 24-25 \\
\text { Processing }\end{array}$ & $\begin{array}{l}\text { June } 29 \\
\text { Processing }\end{array}$ \\
\hline orizzly & \multicolumn{2}{|c|}{$\begin{array}{l}\text { Opening Between Bars } \\
\text { Estimated feed Rate }\end{array}$} & $\begin{array}{l}150 \mathrm{~mm} \\
20.0 \text { tons } / \mathrm{hr}\end{array}$ & $\begin{array}{l}150 \mathrm{~mm} \\
22.5 \mathrm{tons} / \mathrm{hr}\end{array}$ & $\begin{array}{l}150 \mathrm{~mm} \\
22.5 \text { tons } / \mathrm{hr}\end{array}$ \\
\hline \multirow[t]{3}{*}{$\begin{array}{l}\text { Primary } \\
\text { Screen }\end{array}$} & \multicolumn{2}{|c|}{$\begin{array}{l}\text { Screen Opening size } \\
\text { screening Area } \\
\text { slope }\end{array}$} & $\begin{array}{l}25 \mathrm{~mm} \\
750 \text { by } 2,400 \mathrm{~mm} \\
0 \text { deg }\end{array}$ & $\begin{array}{l}25 \mathrm{~mm} \\
750 \text { by } 2,400 \mathrm{~mm} \\
0 \mathrm{deg}\end{array}$ & $\begin{array}{l}25 \mathrm{~mm} \\
750 \text { by } 2,400 \mathrm{~mm} \\
0 \text { deg }\end{array}$ \\
\hline & $\begin{array}{l}\text { Rinse } \\
\text { Nozzles }\end{array}$ & $\begin{array}{l}\text { Pressure } \\
\text { Flowrate } \\
=L / \text { ton }\end{array}$ & $\begin{array}{l}2.8 \mathrm{~kg} / \mathrm{cm}^{2} \\
38 \mathrm{~L} / \mathrm{min}^{2} \\
200 \mathrm{~L} / \text { ton } \\
(50 \mathrm{gal} / \text { ton })\end{array}$ & $\begin{array}{l}2.8 \mathrm{~kg} / \mathrm{cm}^{2} \\
38 \mathrm{~L} / \mathrm{min} \\
220 \mathrm{~L} / \text { ton } \\
(60 \mathrm{gal} / \text { ton })\end{array}$ & $\begin{array}{l}2.8 \mathrm{~kg} / \mathrm{cm}^{2} \\
38 \mathrm{~L} / \mathrm{min} \\
220 \mathrm{~L} / \text { ton } \\
(60 \mathrm{ga} / / \text { ton })\end{array}$ \\
\hline & \multicolumn{2}{|c|}{ Estimated Foed Rate } & 19.4 tons $/ \mathrm{hr}$ & 21.9 tons $/ \mathrm{hr}$ & 21.9 tons $/ \mathrm{hr}$ \\
\hline \multirow[t]{5}{*}{ Trommal } & \multicolumn{2}{|c|}{$\begin{array}{l}\text { Screen Opening size } \\
\text { Overall Dimensions } \\
\text { Rotational Speed } \\
\text { slope } \\
\text { Retention (wash) rime }\end{array}$} & $\begin{array}{l}2 \mathrm{~mm} \\
1.4 \mathrm{~m} \text { dia. by } 6.4 \mathrm{~m} \\
5 \mathrm{rpm} \\
3 \mathrm{deg} \\
3 \mathrm{~min}\end{array}$ & $\begin{array}{l}2 \mathrm{~mm} \\
1.4 \mathrm{~m} \text { dia. by } 6.4 \mathrm{~m} \\
5 \mathrm{rpm} \\
3 \mathrm{deg} \\
3 \mathrm{~min}\end{array}$ & $\begin{array}{l}2 \mathrm{~mm} \\
1.4 \mathrm{~m} \text { dia. by } 6.4 \mathrm{~m} \\
5 \mathrm{rpm} \\
0 \mathrm{deg} \\
20 \mathrm{~min}\end{array}$ \\
\hline & $\begin{array}{l}\text { Initial } \\
\text { Rinse } \\
\text { Nozzles }\end{array}$ & $\begin{array}{l}\text { Pressure } \\
\text { Flowrate } \\
\text { - L/ton }\end{array}$ & $\begin{array}{l}4.2 \mathrm{~kg} / \mathrm{cm}^{2} \\
600 \mathrm{~L} / \mathrm{min} \\
11,500 \mathrm{~L} / \text { ton } \\
(3,050 \mathrm{gal} / \text { ton })\end{array}$ & $\begin{array}{l}4.2 \mathrm{~kg} / \mathrm{cm}^{2} \\
600 \mathrm{~L} / \mathrm{min} \\
29,600 \mathrm{~L} / \text { ton } \\
(7,800 \mathrm{gal} / \text { ton })\end{array}$ & $\begin{array}{l}4.2 \mathrm{~kg} / \mathrm{cm}^{2} \\
600 \mathrm{~L} / \mathrm{min}^{2} \\
84,000 \mathrm{~L} / \text { ton } \\
(22,200 \mathrm{gal} / \text { ton })\end{array}$ \\
\hline & $\begin{array}{l}\text { Wash } \\
\text { Water } \\
\text { Nozzle }\end{array}$ & $\begin{array}{l}\text { Pressure } \\
\text { Flowrate } \\
\approx \mathrm{L} / \text { ton }\end{array}$ & $\begin{array}{l}2.8 \mathrm{~kg} / \mathrm{cm}^{2} \\
75 \mathrm{~L} / \mathrm{min} \\
3,600 \mathrm{~L} / \mathrm{ton} \\
(900 \mathrm{gal} / \text { ton })\end{array}$ & $\begin{array}{l}2.8 \mathrm{~kg} / \mathrm{cm}^{2} \\
55 \mathrm{~L} / \mathrm{min} \\
7,750 \mathrm{~L} / \text { ton } \\
(2,000 \mathrm{gal} / \text { ton })\end{array}$ & $\begin{array}{l}2.8 \mathrm{~kg} / \mathrm{cm}^{2} \\
75 \mathrm{~L} / \mathrm{min} \\
21,000 \mathrm{~L} / \text { ton } \\
(5,500 \mathrm{gal} / \text { ton })\end{array}$ \\
\hline & $\begin{array}{l}\text { Final } \\
\text { Rinse } \\
\text { Nozzles }\end{array}$ & $\begin{array}{l}\text { Pressure } \\
\text { Flowrate } \\
\text { = L/ton }\end{array}$ & $\begin{array}{l}2.8 \mathrm{~kg} / \mathrm{cm}^{2} \\
305 \mathrm{~L} / \text { min } \\
14,500 \mathrm{~L} / \text { ton } \\
(3.800 \mathrm{gel} / \text { ton })\end{array}$ & $\begin{array}{l}2.8 \mathrm{~kg} / \mathrm{cm}^{2} \\
220 \mathrm{~L} / \mathrm{min} \\
31,000 \mathrm{~L} / \mathrm{ton} \\
(8,200 \mathrm{gal} / \text { ton })\end{array}$ & $\begin{array}{l}2.8 \mathrm{~kg} / \mathrm{cm}^{2} \\
305 \mathrm{~L} / \mathrm{min} \\
85,400 \mathrm{~L} / \text { ton } \\
(22,600 \mathrm{gal} / \text { ton })\end{array}$ \\
\hline & \multicolumn{2}{|c|}{ Estimated Feed Rate } & 3.4 tons $/ \mathrm{hr}$ & $1.2 \mathrm{tons} / \mathrm{hr}$ & 0.6 tons $/ \mathrm{hr}$ \\
\hline $\begin{array}{l}\text { Secondary } \\
\text { Screen }\end{array}$ & \multicolumn{2}{|c|}{$\begin{array}{l}\text { Screen Opening size } \\
\text { screening Area } \\
\text { slope } \\
\text { speed setting }(x) \\
\text { Feed slurry Density } \\
\text { Estimated Feed Rate } \\
\text { Estimated slurry } \\
\text { Flowrate }\end{array}$} & $\begin{array}{l}0.425 \mathrm{~mm} \\
0.56 \mathrm{by} 2.1 \mathrm{~m} \\
0 \mathrm{dog} \\
100 \\
7.3 \% \mathrm{dry} \mathrm{solids} \\
2.0 \mathrm{rons} / \mathrm{hr} \\
390 \mathrm{~L} / \mathrm{min}\end{array}$ & $\begin{array}{l}0.425 \mathrm{~mm} \\
0.56 \mathrm{by} 2.1 \mathrm{~m} \\
0 \mathrm{deg} \\
100 \\
3.0 \% \mathrm{dry} \mathrm{sollds} \\
0.5 \mathrm{ton} / \mathrm{hr} \\
350 \mathrm{~L} / \mathrm{min}\end{array}$ & $\begin{array}{l}0.425 \mathrm{~mm} \\
0.56 \text { by } 2.1 \mathrm{~m} \\
0 \mathrm{deg} \\
100 \\
0.8 \% \mathrm{dry} \mathrm{solids} \\
0.2 \mathrm{ton} / \mathrm{hr} \\
375 \mathrm{~L} / \mathrm{min}\end{array}$ \\
\hline
\end{tabular}


Processing occurred on June 23, 24, 25, and 29, 1993. The feed soils that were processed each day were all very similar. As a result, the analytical results for sampling done on the various days are combined in this report. Minor differences in soll characteristics and contaminant composition exist; however, the primary differences each day are in the problems with the system and adjustments that were made.

Prior to the beginning of processing for each day, plastic liners were laid down for each process stream to ensure that processed material was not mixed with any of the existing material or with previously processed material.

Solls for processing were excavated from the southwest corner of the north process pond near the inlet end of the ponds (see Figure 1-2). Phase I RI characterization data (DOE-RL 1993C) show that this is the most contaminated portion of the pond. Soils were excavated within $1.0 \mathrm{~m}$ of the surface in an attempt to avoid the higher concentrations of uranium, which were characterized by a greenish appearance (green material). Based on Dennison et a1. (1989) and the RI Phase I report (DOE-RL 1993c), this material was believed to be confined to a thin layer about $1.5 \mathrm{~m}$ beneath the ground surface.

However, during excavation of the feed material, it was discovered that green material was distributed throughout the soils in this particular area. Associated with the green particles are white-colored particles. The white particles are assumed to be from the whitish layer visible directly above the green layer where cuts have been made through undisturbed portions of the material. Rarely is one seen without the other being present. The green material always exhibited higher levels of activity than the white material and appears to be the major contributor of uranium contamination in the pond. In this report, green material refers to the green and white particles, unless specifically noted.

A field decision was made on June 23 to process the green material to determine what system modifications, if any, would be needed to meet test performance levels.

Solls were not processed continuously, as in the pre-test run, to ensure minimal dust exposure. The procedure was as follows. Solls to be processed were wetted down thoroughly prior to excavation. Soils were fed to the grizziy and separated by the 25-m vibrating screen unt 11 the primary hopper was full. After the hopper was full, the conveyor system to the trommel was turned on and the trommel started.

This operating approach (noncontinuous operation and heavy wetting of the soils) resulted in several processing problems including less control in dumping material from the backhoe bucket, overloading of the primary screen resulting in insufficient washing of the oversize material, and clogging of the primary conveyor.

In addition, problems with the system occurred such as the discovery of blank plates inserted between the valves and the tank on the fractionation tanks, discharge chutes too flat to flow freely, and the collapse of the middle section of one of the discharge chutes. These were all untested parts of the system that could not be refined during the pre-test. 
The end result of the first day of processing was that radioactivity levels measured in the field using a Geiger Mueller (GM) detector probe (Eberline, Albuquerque, New Mexico, Model E-140B) (exceeded test performance levels (Table 2-1) in each of the process piles. The green material basically passed through the system without breaking down to any significant degree.

On the second day of the test, June 24, a new location near the inlet end of the ponds (approximately $10 \mathrm{~m}$ from the June 23 site) and nearer to the ground surface was selected from which to excavate soils in an attempt to avoid the green material. Again, green particles were found distributed throughout the excavated soils.

No changes were made in the operating parameters of the system. The same noncontinuous operating approach was used on June 24 . However, the feed solls were not wetted down as heavily and the backhoe operator had better success controlling the feed rate to the system. This resulted in the oversize material from the primary screen receiving a more thorough rinse, and more fine soils being sent to the trommel. This caused the trommel slurry discharge line to be plugged before the trommel was ever started. Additional problems included a blown fuse in the secondary screen and a sheared pin on the trommel metering wheel.

The net result was that not very much processing occurred and the hopper under the primary screen was still two-thirds full. The limited processing showed the same results as June 23; contamination in all process piles.

On June 25, processing began to empty out the hopper. No additional material was fed to the system by the backhoe. The system was working smoothly until the fresh water supply pump began to fail. Fresh water pressure to the system dropped significantly and to prevent the system from running out of water while full of solls, the feed to the trommel had to be shut off numerous times. This resulted in different flowrates of the wash nozzles and the final rinse nozzles in the trommel, and affected the water-tosolids ratios for those sections. Eventually, the lack of sufficient water forced the processing to be discontinued before the hopper could be emptied.

Only about 0.5 ton remained in the hopper, which needed to be emptied, and it was determined by the project engineers that some system changes would be beneficial to see what effect they might have on the green material. No additional feed material was fed to the primary screen and hopper.

One change made to the system was to decrease the slope of the trommel from 3 to 0 deg to increase the retention (wash) time. It was hoped that the increased retention time for the oversize material in the trommel would be enough to allow the green material in that size range to be broken down.

On June 29, the processing werit smoothly until the fresh water supply pump lost pressure again. However, since this occurred at the end of the processing, it did not have any substantial impacts.

Field measurements with hand-held instruments by the Health Physics personnel were taken on each of the piles from this run and some success was seen in the 25- to 2-mm pile, the oversize from the trommel. However, there was still some contamination in the pile and further work needs to be done. 
This completed the processing for Test \#1. In spite of the problems and concerns associated with Test \#1, an estimated 17.5 tons of material was processed. HEIS numbers of soil and effluent samples taken during Test \#1 are shown in Table 4-1.

The following is a description and summary of data analyses obtained as part of Test \#1. Complete data analyses results are included in Appendix B.1 and the PNL sediment characterization report (Serne et al. 1993).

\subsection{FEED SOILS AND FRESH WATER}

\subsubsection{Particle Size Distribution}

Samples (Table 4-1) were sent to offsite analytical laboratories for chemical and radiochemical analyses and to onsite laboratories for sieve analysis and chemical and radiochemical analysis of soils in each size fraction after sieving.

The particle size distribution of the feed soils processed in Test \#l is shown in Table 6-3 and Figure 6-2a. Figure 6-2b shows the percent of the total processed material reporting to each process pile. The soils were located near the pond inlet and within $0.5 \mathrm{~m}$ of the ground surface.

Therefore, they contain more fine particles than anticipated based on the RI Phase I studies and previous characterization of solls conducted by Serne et al. (1992). However, as shown in Figure 6-1a, a $90 \%$ reduction by weight could still be achieved if solls are successfully separated with particles $>0.212 \mathrm{~mm}$ meeting established performance levels.

\subsubsection{Analytical Results}

Field measurements using a GM probe showed that feed soils contained up to $35,000 \mathrm{dpm}$ above background $(500 \mathrm{dpm})$. These were the hottest soils found in the north pond using the hand-held GM probes.

The average concentration and standard deviation for offsite chemical and radiochemical contaminants in feed soils $<25 \mathrm{~mm}$ are shown in Table 6-4. These data show that prior to processing, only uranium concentrations were greater than the performance levels for contaminants specified in the test plan (see Table 2-1). The radionuclides other than uranium are of low enough concentrations that their actual detection could be questioned. Some are decay products in the uranium chain and some were detected in the Phase I RI characterization work, but all are of low enough concentrations that they are not of concern. This is true of all of the gamma spectrometer radionuclide analyses presented in this report. PCBs were not analyzed for in Test \#1 due to miscommunication with the analytical laboratories.

Also shown in Table 6-4 are the average concentration and standard deviation for chemical and radiochemical contaminants in the feed water. 
Table 6-3. Wet-Sieved Size Distribution of Feed Solls

in Test \#1 (Percent by Weight). (Serne et a1. 1993)

\begin{tabular}{|l|c|c|c|}
\hline \multicolumn{1}{|c|}{ Size Fraction } & $\begin{array}{c}\text { June 23 } \\
\text { Processing }\end{array}$ & $\begin{array}{c}\text { June 24-25 } \\
\text { Processing }\end{array}$ & $\begin{array}{c}\text { Test \#1 } \\
\text { Average }\end{array}$ \\
\hline$>25 \mathrm{~mm}$ & $60.5 \%$ & $51.2 \%$ & $55.9 \%$ \\
\hline 25 to $2 \mathrm{~mm}$ & $14.3 \%$ & $25.5 \%$ & $19.9 \%$ \\
\hline 2 to $0.425 \mathrm{~mm}$ & $12.3 \%$ & $11.7 \%$ & $12.0 \%$ \\
\hline 0.425 to $0.212 \mathrm{~mm}$ & $5.81 \%$ & $5.32 \%$ & $5.57 \%$ \\
\hline 0.212 to $0.150 \mathrm{~mm}$ & $1.26 \%$ & $1.16 \%$ & $1.21 \%$ \\
\hline 0.150 to $0.075 \mathrm{~mm}$ & $2.30 \%$ & $2.00 \%$ & $2.15 \%$ \\
\hline$<0.075 \mathrm{~mm}$ & $3.49 \%$ & $3.06 \%$ & $3.28 \%$ \\
\hline
\end{tabular}

Green- and white-colored soils were separated (based on appearance) in the laboratory from unused portions of Test \#1 feed soil samples sent to an onsite laboratory. Table 6-5 shows that the 9.5- to 1-mm white-colored soils were made up primarily of aluminum and silicate and were less radioactive than the green particles. The same sizes of green material contained lower concentrations of aluminum than the white material and higher concentrations of. calcium, copper, zirconium, and uranium. A more detailed analyses of the green material is given in Table 6-5.

\subsection{PROCESSED SOILS AND EFFLUENT}

\subsubsection{Separation Efficiency}

Samples collected from each process pile were sent to an onsite laboratory for analytical screening by size fraction. Sieve analyses (Table 6-6) indicate that $<2 \%$ of the particles were smaller than the desired cut in the $>150-\mathrm{mm}, 150-$ to $25-\mathrm{mm}$, and 25- to 2-mm process piles. About $18 \%$ of the soils retained on the $0.425-\mathrm{mm}$ sieve were smaller than $0.425 \mathrm{~mm}$. of these, $13.6 \%$ werg in the size range from 0.425 to $0.212 \mathrm{~mm}$. One likely explanation for this high percentage of $0.425-$ to $0.212-\mathrm{mm}$ material is that green material that was sightly larger than $0.425 \mathrm{~mm}$ in size after processing in the field was broken down enough during the wet-sieving analysis to pass through a $0.425-\mathrm{mm}$ sieve.

Defining separation efficiency as the percent of material that actually passes through a screen compared to the amount avallable to pass through it, the following separation efficiencies for the various screens were calculated.

The 25-mm primary screen operated in excess of 95\% efficiency. Despite a fairly high efficiency, fines that were not rinsed off this material did cause contamination in this pile. 
Figure 6-2a. Average Wet-Sieved Size Distribution of Feed Soils in Test \#1 (Percent by Weight) (Serne et al. 1993).

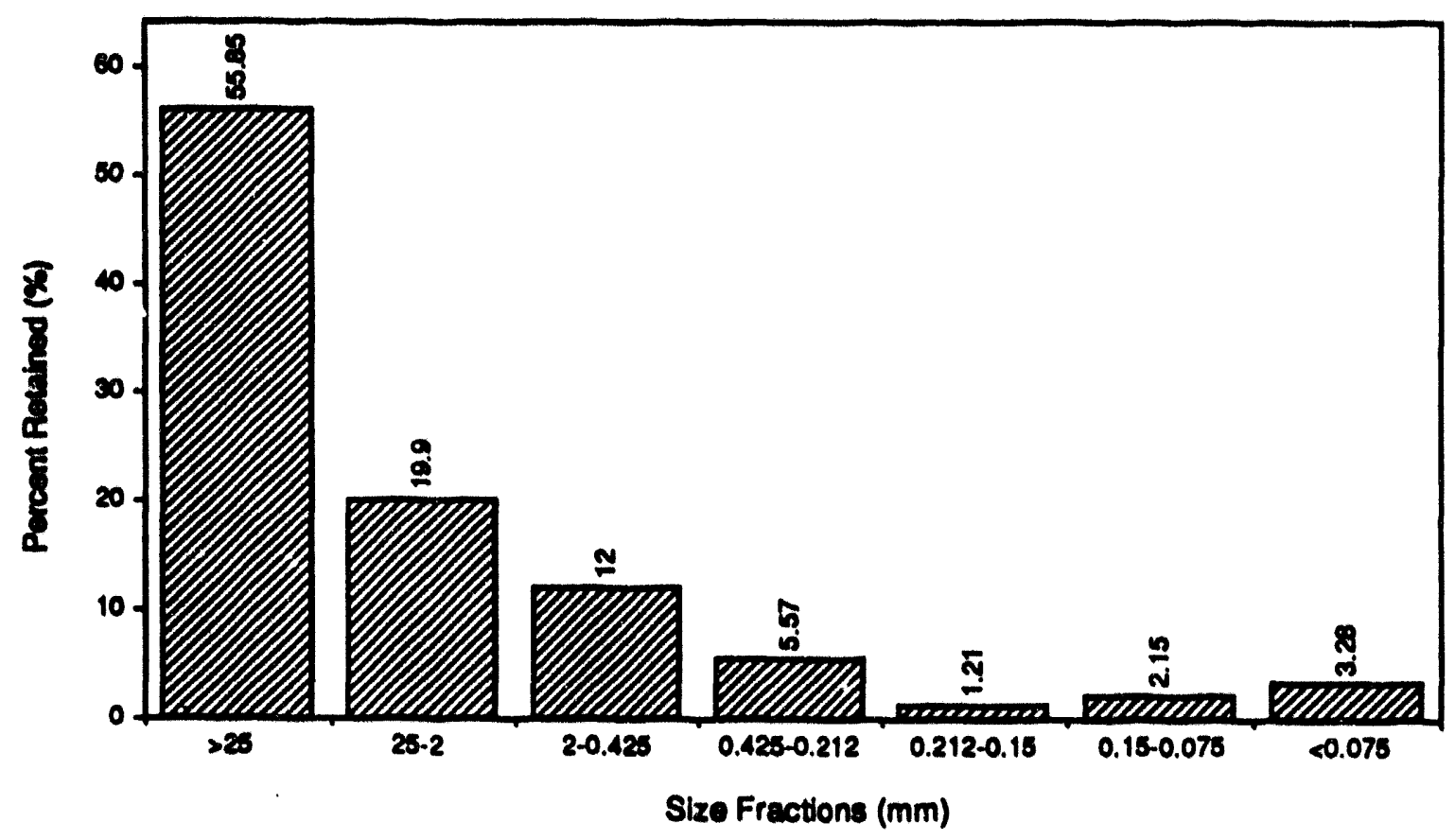

Figure 6-2b. Percent of Soils in Each Process Pile, Test \#1 (Percent by Weight).

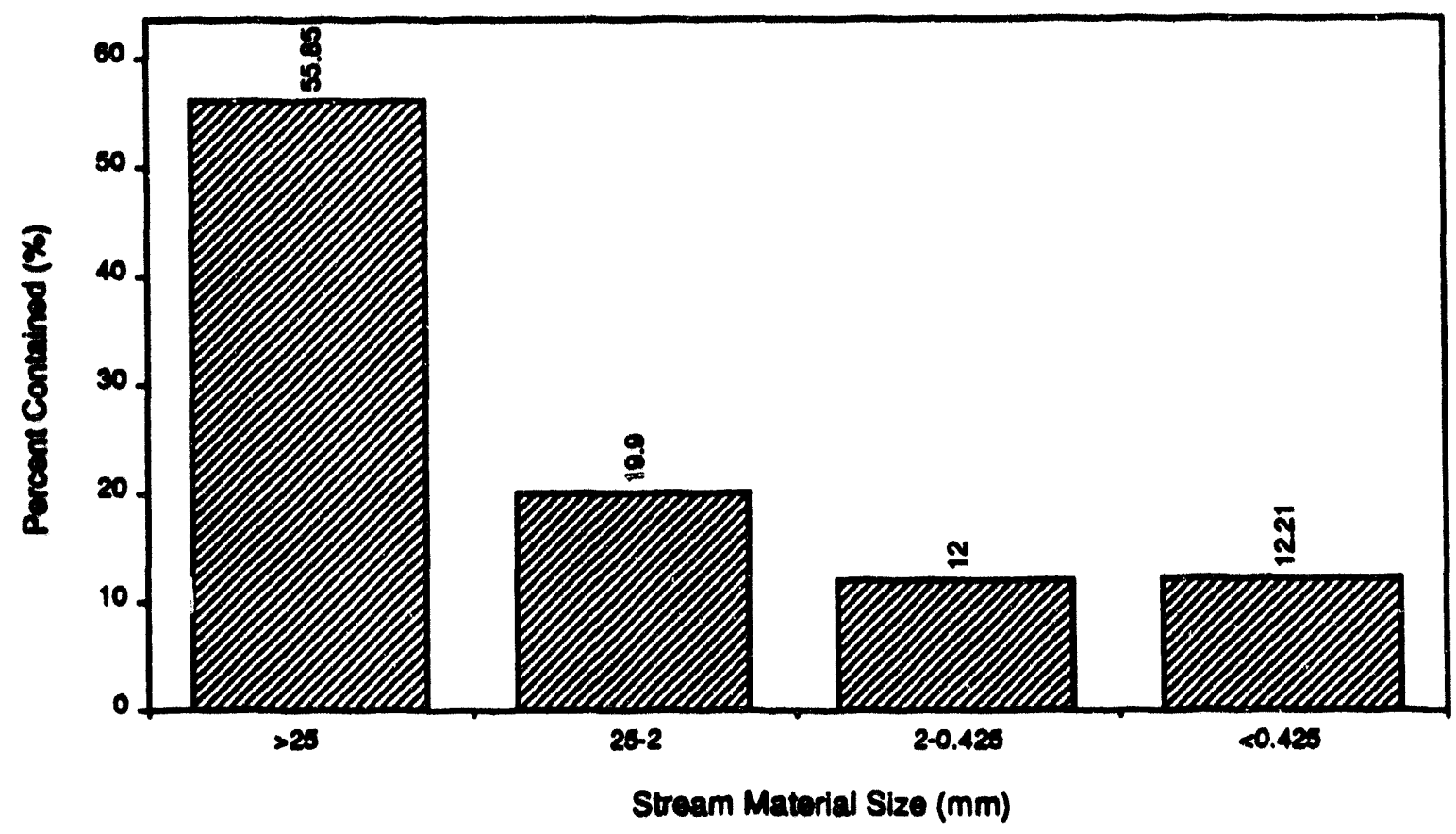

GEMM112002-D 
Table 6-4. Chemical and Radiochemical Analyses of Feed Soils $<25 \mathrm{~mm}$ and Feed Water for Test \#1 (Appendix B.1).

\begin{tabular}{|c|c|c|c|c|}
\hline \multirow{2}{*}{ Const i tuent } & \multicolumn{2}{|c|}{ Feed Soils } & \multicolumn{2}{|c|}{ Feed Water } \\
\hline & Avg & s & Avg & $\mathbf{s}$ \\
\hline $\begin{array}{l}\text { Cobalt-60 } \\
\text { Cesiun-137 } \\
\text { Lead-212 } \\
\text { Lead-214 } \\
\text { Radiun-224a } \\
\text { Radiu-226 } \\
\text { Ruthenium-106 } \\
\text { Ant inomy-125 } \\
\text { Uranium (total) }\end{array}$ & $\begin{array}{r}(p \subset i / g) \\
0.0 \\
0.2 \\
1.4 \\
0.5 \\
0.6 \\
1.3 \\
0.0 \\
0.0 \\
1.802\end{array}$ & $\begin{array}{r}(p C i / g) \\
0.0 \\
0.1 \\
0.4 \\
0.1 \\
0.3 \\
0.5 \\
0.2 \\
0.1 \\
923\end{array}$ & $\begin{array}{l}(\mathrm{pCi} / \mathrm{L}) \\
6.42 \\
2.44 \\
0 \\
0 \\
0 \\
0 \\
6.31 \\
0.0 \\
0.60\end{array}$ & $\begin{array}{l}(p C i / L) \\
3.31 \\
1.84 \\
0 \\
0 \\
0 \\
0 \\
7.57 \\
0.0 \\
0.41\end{array}$ \\
\hline 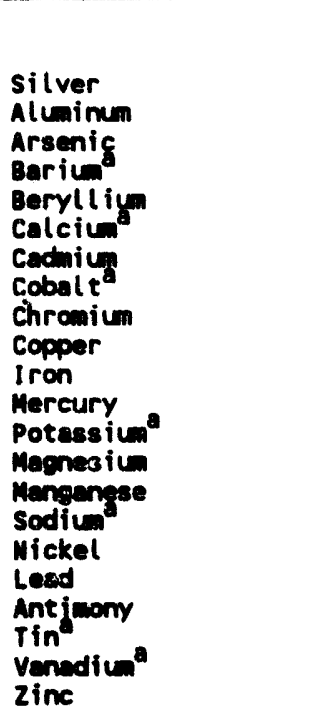 & $\begin{array}{c}(\mathrm{mg} / \mathrm{kg}) \\
21.0 \\
22,571 \\
2.2 \\
1,062.9 \\
0.5 \\
11,086 \\
0.4 \\
6.9 \\
224.3 \\
2,763 \\
16,857 \\
2.3 \\
1,046 \\
6,386 \\
253 \\
2,043 \\
278 \\
47.9 \\
5.9 \\
21.3 \\
37.1 \\
86.7\end{array}$ & $\begin{array}{c}\text { (mg/kg) } \\
20.2 \\
3,923 \\
0.7 \\
522 \\
0.5 \\
26,702 \\
0.5 \\
0.4 \\
132 \\
3,123 \\
1,355 \\
0.6 \\
250 \\
766 \\
10.3 \\
592 \\
289 \\
17.1 \\
4.3 \\
12.6 \\
3.3 \\
28.2\end{array}$ & $\begin{array}{l}(\mathrm{mg} / \mathrm{L}) \\
0 \\
0.15 \\
0 \\
0.026 \\
0 \\
18 \\
0 \\
0 \\
0 \\
0.007 \\
0.42 \\
0 \\
0.92 \\
4.2 \\
0.012 \\
2.8 \\
0 \\
0.005 \\
0 \\
0 \\
0.001 \\
0.005\end{array}$ & $\begin{array}{l}(\mathrm{mg} / \mathrm{L}) \\
0 \\
0.076 \\
0 \\
0 \\
0 \\
i .41 \\
0 \\
0 \\
0 \\
0.003 \\
0.031 \\
0 \\
0.43 \\
0.309 \\
0.001 \\
0.28 \\
0 \\
0.003 \\
0 \\
0 \\
0.002 \\
0.003\end{array}$ \\
\hline $\begin{array}{l}\text { (Water only) } \\
\text { Chloroform } \\
\text { Methyl ethyl ketone } \\
\text { Tetrachloroethylene } \\
\text { Tetrahydrofuran } \\
\text { Trichloroethylene }\end{array}$ & $\begin{array}{l}M A \\
M A \\
M A \\
M A \\
M A\end{array}$ & $\begin{array}{l}M A \\
M A \\
M A \\
M A \\
M A\end{array}$ & $\begin{array}{c}0.02 \\
U \\
U \\
U \\
U\end{array}$ & $\begin{array}{l}0.0 \\
0.0 \\
0.0 \\
0.0\end{array}$ \\
\hline
\end{tabular}

$S$ a standard deviation; $U=$ undetected; $M A=$ not analyzed.

MOTE: Material $>25 \mathrm{~mm}$ is not able to be handled by the laboratory. Material between 25 and $2 \mathrm{~mm}$ was crushed to $2 \mathrm{~mm}$ or less and then enalyzed.

"Constituents detected in the laboratory, but not identified in Table 2-1. 
DOE/RL-93-96, Rev. 0

Table 6-5. Composition of Green and White Sediment in the 300-FF-1 North Pond (Weight Percent).

(Serne et al. 1993)

\begin{tabular}{|c|c|c|c|c|}
\hline Constituents & $\begin{array}{l}\text { Green } \\
\text { (2 to } 1 \mathrm{~mm})\end{array}$ & $\begin{array}{c}\text { Green } \\
(9.5 \text { to } 2 \mathrm{~mm})\end{array}$ & $\begin{array}{l}\text { White } \\
\text { (2 to } 1 \mathrm{~mm} \text { ) }\end{array}$ & $\begin{array}{c}\text { White } \\
(9.5 \text { to } 2 \mathrm{~mm})\end{array}$ \\
\hline $\mathrm{Na}_{2}$ & 0.31 & 1.21 & 1.12 & 0.71 \\
\hline $\mathrm{MgO}$ & 3.04 & 4.19 & 0.70 & 0.12 \\
\hline $\mathrm{Al}_{2} \mathrm{O}_{3}$ & 31.21 & 24.80 & 50.59 & 56.94 \\
\hline $\mathrm{SiO}_{2}$ & 7.71 & 20.43 & 12.00 & 5.41 \\
\hline $\mathrm{K}_{2} \mathrm{O}$ & 0.16 & 0.33 & 0.18 & 0.06 \\
\hline $\mathrm{CaO}$ & 7.50 & 9.00 & 2.49 & 1.28 \\
\hline $\mathrm{TiO}_{2}$ & 0.05 & 0.14 & 0.05 & 0.02 \\
\hline $\mathrm{Cr}_{2} \mathrm{O}_{3}$ & 0.16 & 0.25 & 0.02 & 0.00 \\
\hline $\mathrm{MnO}_{2}$ & 0.06 & 0.06 & 0.01 & 0.00 \\
\hline $\mathrm{Fe}_{2} \mathrm{O}_{3}$ & 0.57 & 2.33 & 0.33 & 0.12 \\
\hline NiO & 0.28 & 0.36 & 0.02 & 0.00 \\
\hline CuO & 7.68 & 4.99 & 0.16 & 0.03 \\
\hline Zno & 0.03 & 0.05 & 0.01 & 0.00 \\
\hline Sro & 0.03 & 0.04 & 0.02 & 0.00 \\
\hline PbO & 0.03 & 0.04 & 0.01 & 0.00 \\
\hline $\mathrm{ZrO}_{2}$ & 1.72 & 2.62 & 0.06 & 0.01 \\
\hline $\mathrm{Ag}_{2} \mathrm{O}$ & 0.02 & 0.03 & 0.00 & 0.00 \\
\hline $\mathrm{SnO}_{2}$ & 0.05 & 0.05 & 0.01 & 0.00 \\
\hline $\mathrm{BaO}$ & 0.03 & 0.05 & 0.02 & 0.00 \\
\hline $\mathrm{UO}_{2}$ & 1.97 & 1.89 & 0.18 & 0.08 \\
\hline $\mathrm{Ce}_{2} \mathrm{O}_{3}$ & 0.0 & 0.02 & 0.00 & 0.00 \\
\hline b & 37.42 & 25.92 & 32.02 & 33.22 \\
\hline
\end{tabular}

The percent concentration of constituents in the sediment are given as oxides such that columns add to $100 \%$. However, the constituents were not in the form of oxides.

boss on ignition to $900^{\circ} \mathrm{C}$ of carbonate and bound waters. 
DOE/RL-93-96, Rev. 0

Table 6-6. Sieve Analyses for Soil Fractions Processed in Test \#1

(Percent by Weight). (Serne et al. 1993)

\begin{tabular}{|l|c|c|c|c|c|}
\hline Fraction (mm) & $>150 \mathrm{~mm}$ & $\begin{array}{c}150 \mathrm{to} \\
25 \mathrm{~mm}\end{array}$ & $\begin{array}{c}25 \text { to } \\
2 \mathrm{~mm}\end{array}$ & $\begin{array}{c}2 \text { to } \\
0.425 \mathrm{~mm}\end{array}$ & $<0.425 \mathrm{~mm}$ \\
\hline$>50.8$ & 96.7 & 87.56 & 0 & 0 & 0 \\
50.8 to 25.4 & 2.85 & 11.26 & 0 & 0 & 0 \\
25.4 to 12.7 & 0 & 0.51 & 31.9 & 0 & 0 \\
12.7 to 9.5 & 0 & 0.03 & 22.5 & 0 & 0 \\
9.5 to 2.0 & 0.03 & 0.02 & 44.5 & 1.48 & 0.38 \\
2.0 to 1.0 & 0.02 & 0.01 & 0.61 & 16.72 & 0.75 \\
1.0 to 0.425 & 0.14 & 0.13 & 0.07 & 63.61 & 6.24 \\
0.425 to & 0.08 & 0.18 & 0.05 & 13.62 & 75.68 \\
0.212 & 0.02 & 0.04 & 0.02 & 0.69 & 7.75 \\
0.212 to 0.15 & 0.05 & 0.08 & 0.02 & 0.59 & 5.68 \\
0.15 to 0.075 & 0.11 & 0.18 & 0.33 & 3.29 & 3.52 \\
$<0.075$ & & & & & \\
\hline
\end{tabular}

Bold indicates size fraction that should be in the pile.

The trommel efficiency for Test \#1 was very high at $99 \%$. This is most likely a result of the high percentage of fines fed to the trommel during this test. As discussed, the fines content was higher than expected from characterization data.

The final screening unit in the system, the $0.425-\mathrm{mm}$ secondary screen, operated at about $82 \%$ efficiency for this test. As with the tromme1, the percentage of fines fed to this unit were high and the efficiency would be expected to be higher also.

\subsubsection{Analytical Results}

Prior to sampling of the process piles, the piles were surveyed with a hand-held GM instrument. Based on these field measurements, activity levels indicated radioactive contamination in all of the process piles. Table 6-7 gives a summary of the field measurements taken on processed soils. The levels measured in the feed soils are also shown for comparison purposes.

Soil and effluent samples (Table 4-1) were collected and sent to an offsite laboratory for analyses to assess which contaminants were in each of the process streams and to determine what water treatment, if any, would be required for effluent to meet purgewater acceptance standards. A summary of laboratory results is shown in Table 6-8. Additional data are included in Appendix B.1. 
Table 6-7. Summary of GM Probe Field Radioactivity Measurements.

\begin{tabular}{|l|c|}
\hline \multicolumn{1}{|c|}{ Size Fraction } & $\begin{array}{c}\text { Radioactivity, } \\
\text { (dpm/100 } \mathrm{cm}^{2} \text { above } \\
\text { background) }\end{array}$ \\
\hline Feed Soils & 2,000 to 35,000 \\
\hline$>150 \mathrm{~mm}$ & 2,000 to 40,000 \\
\hline 150 to $25 \mathrm{~mm}$ & 3,000 to 6,000 \\
\hline 25 to $2 \mathrm{~mm}$ & 1,500 to 25,000 \\
\hline 2 to $0.425 \mathrm{~mm}$ & 6,500 to 20,000 \\
\hline$<0.425 \mathrm{~mm}$ (soils) & 3,000 to 6,000 \\
\hline
\end{tabular}

'Background about $500 \mathrm{dpm}$.

Data in Table 6-8 show that all the constituents in all the procoss streams were below the test performance limits except uranium. This was also true of the feed soils prior to processing (see Table 6-4). In addition, unfiltered laboratory analyses of process effluent show significant uranium concentrations (Table 6-8).

Analysis confirmed that VOCs are not contaminants that need to be addressed in the north pond area. VOCs found were near purgewater limits. samples.

Offsite analytical laboratories did not provide data for filtered

TCLP analyses (Appendix B.1) showed that all constituents analyzed for were significantly below regulatory limits (40 CFR Part 261.24).

Soil and effluent samples (Tabie 4-1) were also sent to an onsite laboratory for analytical screening by size fraction. This was done to assess the effectiveness of this system to physically separate and concentrate the contaminants in the fines.

After wet-sieving and determining the size fraction of soils in each of the piles, soils from the same size fractions were composited for XRF measurements and counting gamma activity levels. The results (Table 6-9) show that contaminants were primarily partitioned to the fine soil particles in each of the fractions, and contaminants were below performance levels specified in the test $\mathrm{plan}$ in the soil fractions $>0.212 \mathrm{~mm}$. Therefore, laboratory analys is of processed material showed that at a cutpoint of $0.425 \mathrm{~mm},>87 \%$ by weight met the test performance levels, and at a cutpoint of $0.212 \mathrm{~mm},>93 \%$ by weight of the soils met test performance levels. 
Table 6-8. Test \#l Analyses for Each of the Process Streams and Unfiltered Effluent (Appendix B.1).

\begin{tabular}{|c|c|c|c|c|}
\hline Constituent & $\begin{array}{l}25 \text { to } 2 \mathrm{~mm} \\
\text { (avg) }\end{array}$ & 2 to $0.425 \mathrm{~mm}$ & $\begin{array}{l}<0.425 \mathrm{~mm} \\
(\text { avg) }\end{array}$ & $\begin{array}{c}\text { Unfiltered } \\
\text { Effluent (avg) }\end{array}$ \\
\hline $\begin{array}{l}\text { Cobalt-60 } \\
\text { Cesium- } 137\end{array}$ & $\begin{array}{r}(p c i / g) \\
0.02 \\
0.06\end{array}$ & $\begin{array}{r}(\mathrm{pCi} / \mathrm{g}) \\
0.03 \\
0.10\end{array}$ & $\begin{array}{r}(\mathrm{pCi} / \mathrm{g}) \\
0.01 \\
0.20\end{array}$ & $\begin{array}{r}(p C i / L) \\
3.36 \\
7.69\end{array}$ \\
\hline Uranium (total) & $\begin{array}{c}(\mu g / L) \\
791\end{array}$ & $\begin{array}{c}(\mu g / L) \\
650\end{array}$ & $\begin{array}{c}(\mu g / L) \\
329\end{array}$ & $\begin{array}{l}(\mu \mathrm{g} / \mathrm{L}) \\
39,886\end{array}$ \\
\hline $\begin{array}{l}\text { Silver } \\
\text { Aluminum } \\
\text { Arsenic } \\
\text { Beryllium } \\
\text { Cachium } \\
\text { Chromium } \\
\text { Curium } \\
\text { Iron } \\
\text { Mercury } \\
\text { Manganese } \\
\text { Nickel } \\
\text { Leed } \\
\text { Antimony } \\
\text { Zinc } \\
\text { (Water only) } \\
\text { Chloroform } \\
\text { Methyl ethyl ketone } \\
\text { Tetrachloroethylene } \\
\text { Tetrahydrofuran } \\
\text { Trichloroethylene }\end{array}$ & $\begin{array}{c}(\mathrm{mg} / \mathrm{kg}) \\
4.39 \\
11,694 \\
0.92 \\
0.11 \\
0.07 \\
62.5 \\
1,318 \\
17,275 \\
0.54 \\
225 \\
104 \\
17.6 \\
0.45 \\
51.2 \\
\\
\mathrm{NA} \\
\mathrm{NA} \\
\mathrm{NA} \\
\mathrm{NA} \\
\mathrm{NA}\end{array}$ & $\begin{array}{c}\text { (mg/kg) } \\
11.1 \\
16,000 \\
1.44 \\
0.04 \\
0.08 \\
122 \\
2,025 \\
17,333 \\
1.18 \\
241 \\
176 \\
32.83 \\
0.93 \\
64.25 \\
\\
\text { NA } \\
\text { NA } \\
\text { NA } \\
\text { NA } \\
\text { NA }\end{array}$ & $\begin{array}{c}\text { (mg/kg) } \\
1.3 \\
8,214 \\
1.4 \\
0.1 \\
0.0 \\
39.1 \\
330 \\
14.571 \\
0.2 \\
184 \\
32.7 \\
15.6 \\
0.7 \\
39.6 \\
\\
\text { NA } \\
\text { NA } \\
\text { NA } \\
\text { NA } \\
\text { NA }\end{array}$ & $\begin{array}{c}(\mathrm{mg} / \mathrm{L}) \\
0.53 \\
562 \\
0.02 \\
0.01 \\
0.0 \\
5.77 \\
52.2 \\
155 \\
0.09 \\
3.52 \\
4.99 \\
1.36 \\
0.0 \\
1.74 \\
\\
0.01 \\
0.05 \\
0.002 \\
U \\
0.007\end{array}$ \\
\hline
\end{tabular}

$U=$ undetected; $M A=$ not analyzed.

constituents analyzed in the laboratory for information, but not identified in Table 2-1.

Schematics showing the distribution of uranium-238, uranium-235, and cobalt-60 by particle size are given in Figures 6-3a, 6-4a, and 6-5a, respectively. Calculated concentrations of uranium-238, uranium-235, and cobalt-60 in each of the process piles are shown in Figures $6-3 b, 6-4 b$, and $6-5 b$.

Values shown were calculated considering the activity levels in each fraction of soils (Table 6-9) and the distribution of soils for each process pile (Table 6-6). 
Table 6-9. Test \#1 Size Distribution of Contaminants in Processed Soils After Wet-Sieving. (Serne et a1. 1993)

\begin{tabular}{|c|c|c|c|c|c|c|c|c|c|c|c|}
\hline $\begin{array}{l}\text { Size }(\mathrm{m}) \\
\text { Contaminant }\end{array}$ & $>50.8$ & $\begin{array}{l}50.8 \\
\text { to } \\
25.4\end{array}$ & $\begin{array}{l}25.4 \\
\text { to } \\
12.7\end{array}$ & $\begin{array}{l}12.7 \\
\text { to } \\
9.5\end{array}$ & $\begin{array}{l}9.5 \\
\text { to } 2\end{array}$ & 2 to 1 & $\begin{array}{l}1 \text { to } \\
0.425\end{array}$ & $\begin{array}{l}0.425 \\
\text { to } \\
0.212\end{array}$ & $\begin{array}{l}0.212 \\
\text { to } \\
0.15\end{array}$ & $\begin{array}{l}0.15 \\
\text { to } \\
0.075\end{array}$ & $<0.075$ \\
\hline $\begin{array}{l}\text { Gama spec } \\
\text { (pci/g) } \\
\text { Cobalt }-60 \\
\text { Cesiun-137 } \\
\text { Uranium-235 } \\
\text { Uranium-238 }\end{array}$ & $\begin{array}{l}0.06 \\
0.05 \\
0.26 \\
1.92\end{array}$ & $\begin{array}{l}0.1 \\
0.05 \\
0.10 \\
0.58\end{array}$ & $\begin{array}{l}0.25 \\
0.25 \\
0.30 \\
2.3\end{array}$ & $\begin{array}{l}1.5 \\
1.1 \\
0.8 \\
4.6\end{array}$ & $\begin{array}{r}2.3 \\
2.3 \\
19.5 \\
149\end{array}$ & $\begin{array}{r}3.9 \\
3.8 \\
37 \\
284\end{array}$ & $\begin{array}{r}4.5 \\
2.5 \\
16.5 \\
147.5\end{array}$ & $\begin{array}{r}3.2 \\
2.4 \\
15.0 \\
119.5 \\
\end{array}$ & $\begin{array}{r}1.6 \\
2.3 \\
24.5 \\
232 \\
\end{array}$ & $\begin{array}{r}4.5 \\
5.0 \\
46.5 \\
461\end{array}$ & $\begin{array}{r}6.0 \\
6.0 \\
149.5 \\
1,083 \\
\end{array}$ \\
\hline 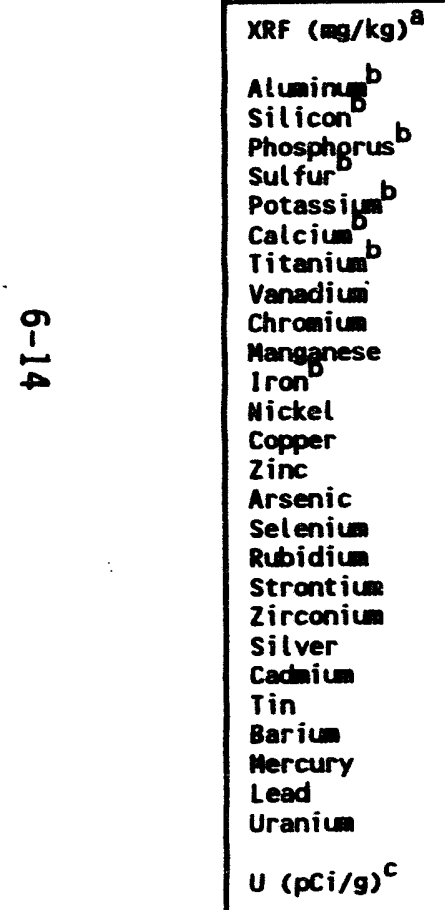 & 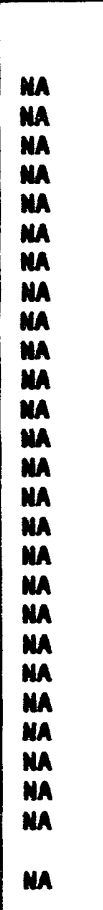 & $\begin{array}{l}m a \\
m \\
m \\
m \\
m a \\
m a \\
m \\
m \\
m a \\
m \\
m \\
m \\
m \\
m a \\
m a \\
m a \\
m a \\
m a \\
m a \\
m a \\
m a \\
m a \\
m a \\
m a \\
m a \\
m a\end{array}$ & 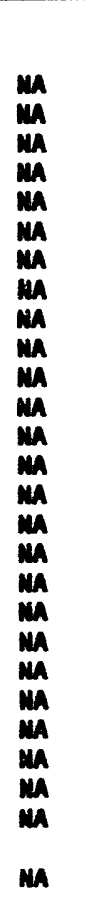 & 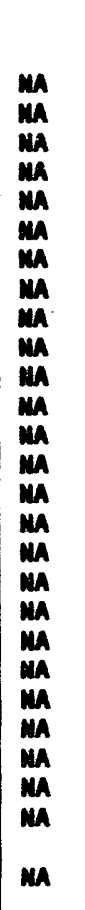 & $\begin{array}{c}10.42 \\
18.5 \\
0.233 \\
0.033 \\
0.79 \\
4.96 \\
1.08 \\
323 \\
152 \\
1,217 \\
7.16 \\
302 \\
3,379 \\
133 \\
5.1 \\
1.9 \\
39 \\
327 \\
1,326 \\
25 \\
8.9 \\
33 \\
573 \\
7.6 \\
38.2 \\
1,179 \\
413 \\
4\end{array}$ & $\begin{array}{c}8.26 \\
21.1 \\
0.335 \\
0.070 \\
1.02 \\
4.35 \\
0.75 \\
183 \\
240 \\
845 \\
5.06 \\
473 \\
5,943 \\
128 \\
4.8 \\
1.9 \\
79 \\
339 \\
2.104 \\
38 \\
9.3 \\
64 \\
897 \\
8.6 \\
67.1 \\
2,291 \\
802\end{array}$ & $\begin{array}{c}7.60 \\
27.6 \\
0.182 \\
0.045 \\
1.38 \\
3.60 \\
0.73 \\
159 \\
130 \\
738 \\
4.40 \\
190 \\
2.010 \\
88 \\
4.8 \\
1.8 \\
59 \\
375 \\
754 \\
14 \\
8.5 \\
26 \\
950 \\
5.3 \\
39.2 \\
983 \\
344\end{array}$ & $\begin{array}{c}7.36 \\
27.8 \\
0.182 \\
0.037 \\
1.46 \\
3.07 \\
0.59 \\
108 \\
163 \\
651 \\
3.79 \\
218 \\
2.166 \\
86 \\
4.6 \\
1.7 \\
63 \\
382 \\
820 \\
22 \\
9.0 \\
30 \\
975 \\
5.3 \\
46.2 \\
858 \\
300\end{array}$ & $\begin{array}{c}7.83 \\
25.0 \\
0.248 \\
0.041 \\
1.29 \\
3.87 \\
0.77 \\
163 \\
259 \\
884 \\
5.26 \\
359 \\
3.460 \\
116 \\
6.8 \\
1.9 \\
67 \\
375 \\
1.308 \\
32 \\
8.9 \\
61 \\
1.088 \\
6.8 \\
65.0 \\
1.425 \\
499\end{array}$ & $\begin{array}{c}8.52 \\
20.2 \\
0.349 \\
0.046 \\
1.09 \\
4.70 \\
0.68 \\
120 \\
410 \\
852 \\
4.79 \\
589 \\
5.933 \\
141 \\
6.4 \\
1.9 \\
92 \\
368 \\
2,143 \\
58 \\
9.5 \\
87 \\
1,405 \\
8.8 \\
103.8 \\
2.493 \\
\\
873\end{array}$ & $\begin{array}{c}9.65 \\
14.9 \\
0.438 \\
0.075 \\
0.91 \\
4.32 \\
0.48 \\
21 \\
677 \\
729 \\
3.24 \\
866 \\
8.145 \\
219 \\
8.1 \\
1.9 \\
196 \\
431 \\
3,290 \\
91 \\
9.0 \\
190 \\
3,513 \\
10.3 \\
155.5 \\
7,078 \\
2,477\end{array}$ \\
\hline
\end{tabular}

$M A=$ not analyzed.

awetals are averages for one run only; data for the second run was simitar and is included in the PNL report (Serne et at. 1993)

$b_{1 x}$ is equivalent to $10,000 \mathrm{mg} / \mathrm{kg}$.

conversion factor for total uranium (mg/kg) times $0.35=\mathrm{pCi} / \mathrm{g}$ for uranium-235 and uranium-238 only. 
Figure 6-3a. Test \#1, Wet-Sieved Size Distribution of Processed Soils, Uranium-238 Gamma Spectrometry. (Serne et al. 1993)

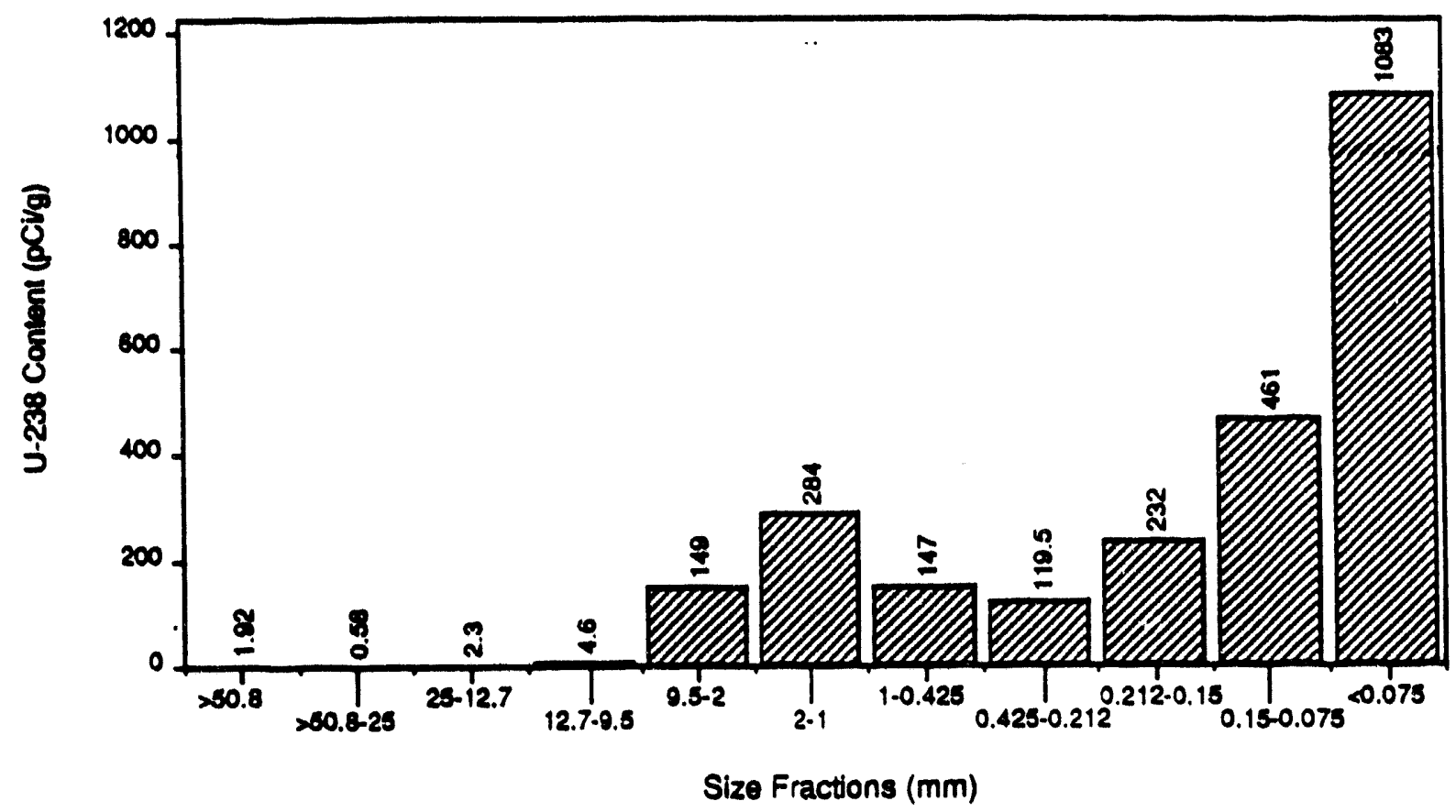

Figure 6-3b. Test \#1, Contaminant Concentrations in Each Process Pile, Uranium-238 Gamma Spectrometry.

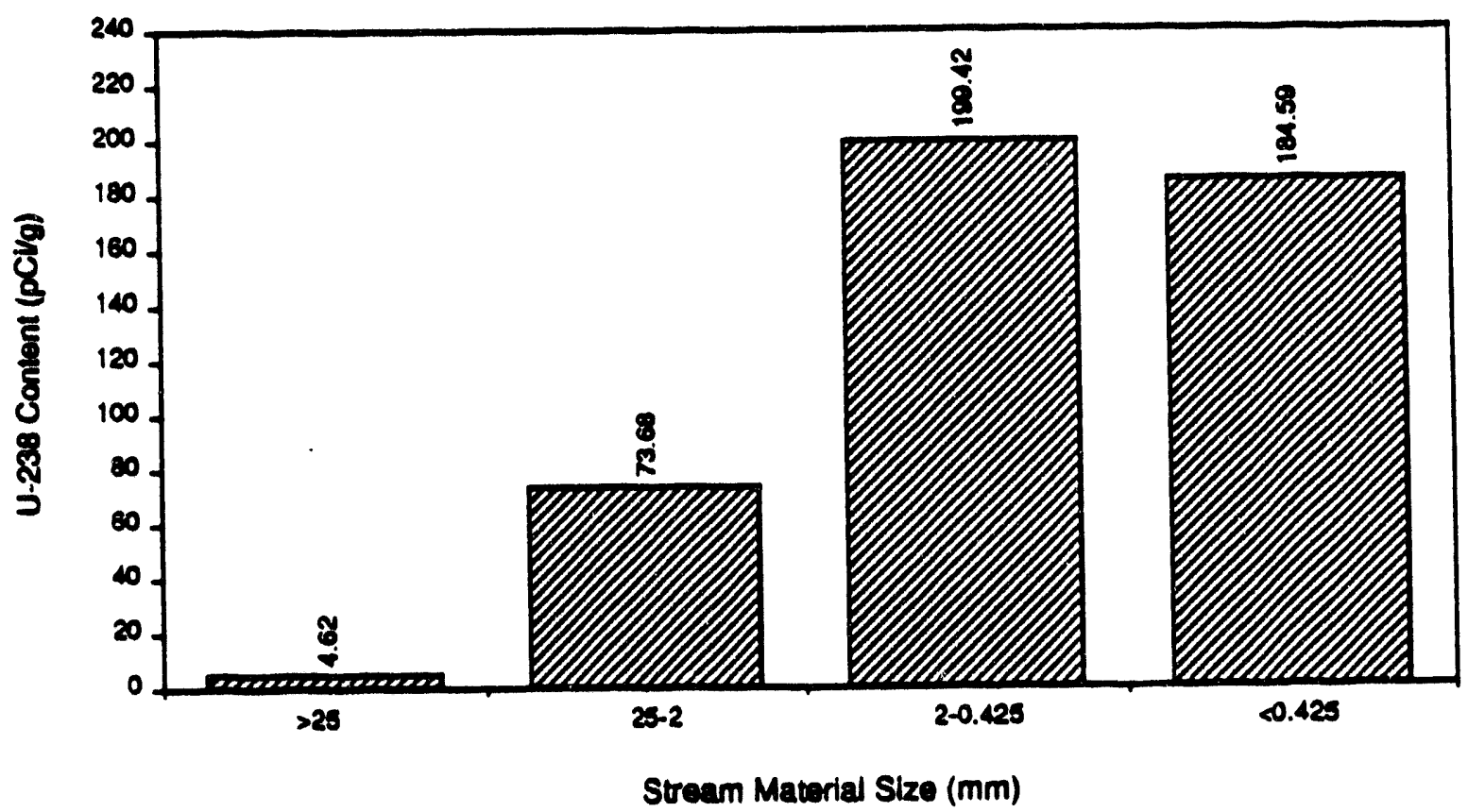


Figure 6-4a. Test \#1, Wet-Sieved Size Distribution of Processed Soils, Uranium-235 Gamma Spectrometry. (Serne et a1. 1993)

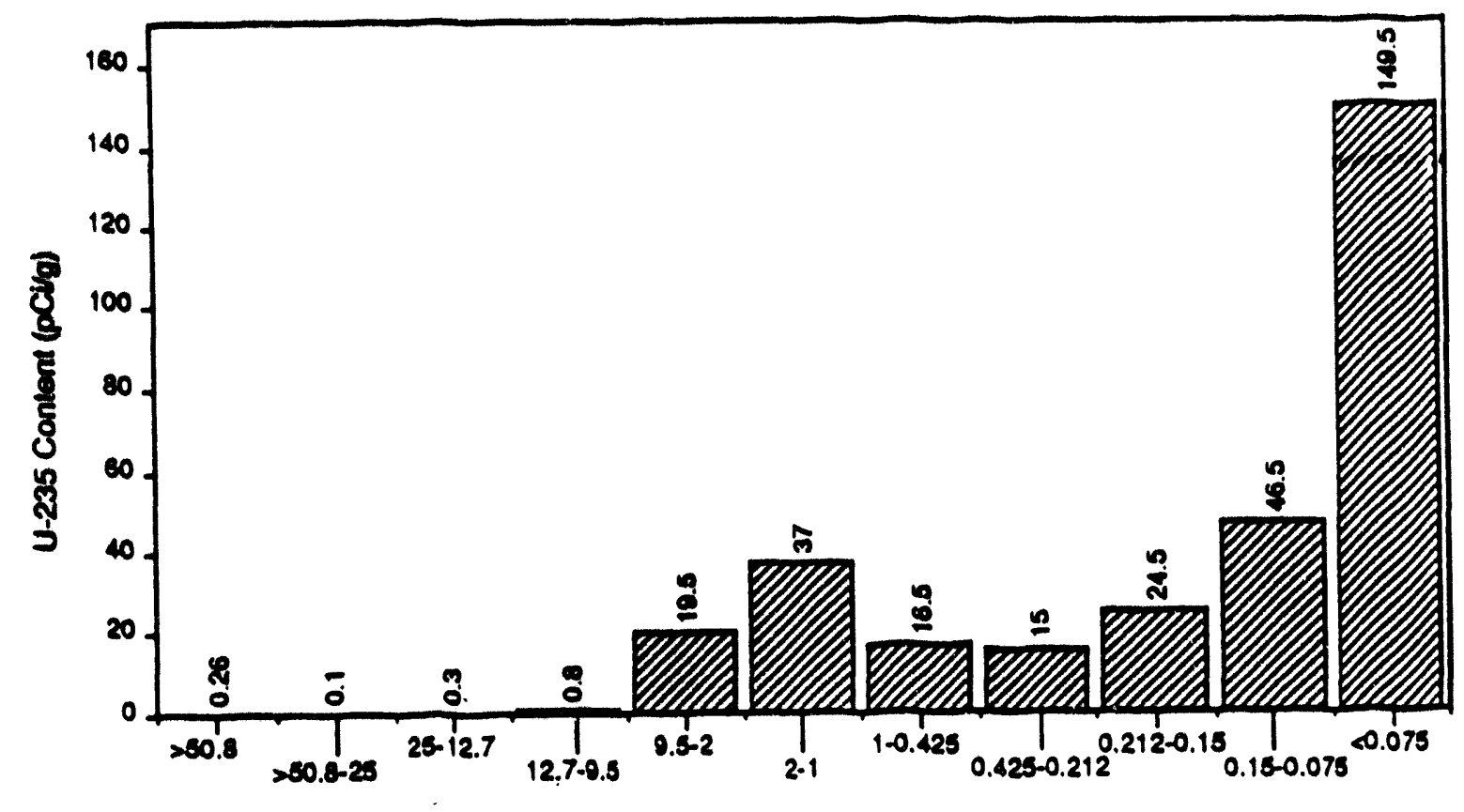

Size Fractions $(\mathrm{mm})$

Figure 6-4b. Test \#1, Contaminant Concentrations in Each Process Pile, Uranium-235 Gamma Spectrometry.

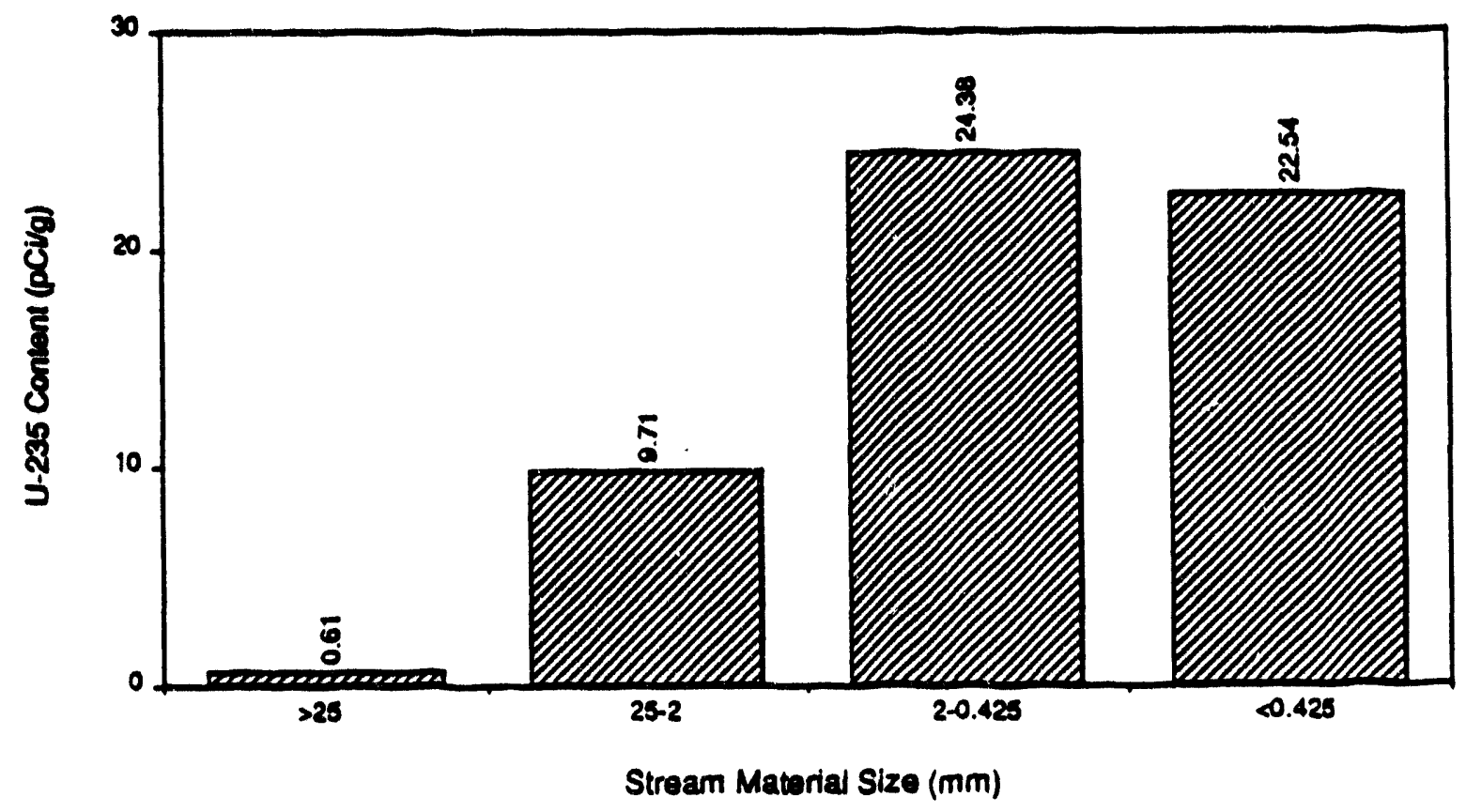

GEMMB.3 
Figure 6-5a. Test \#1, Wet-Sieved Size Distribution of Processed Soils, Cobalt-60 Gamma Spectrometry. (Serne et a1. 1993)

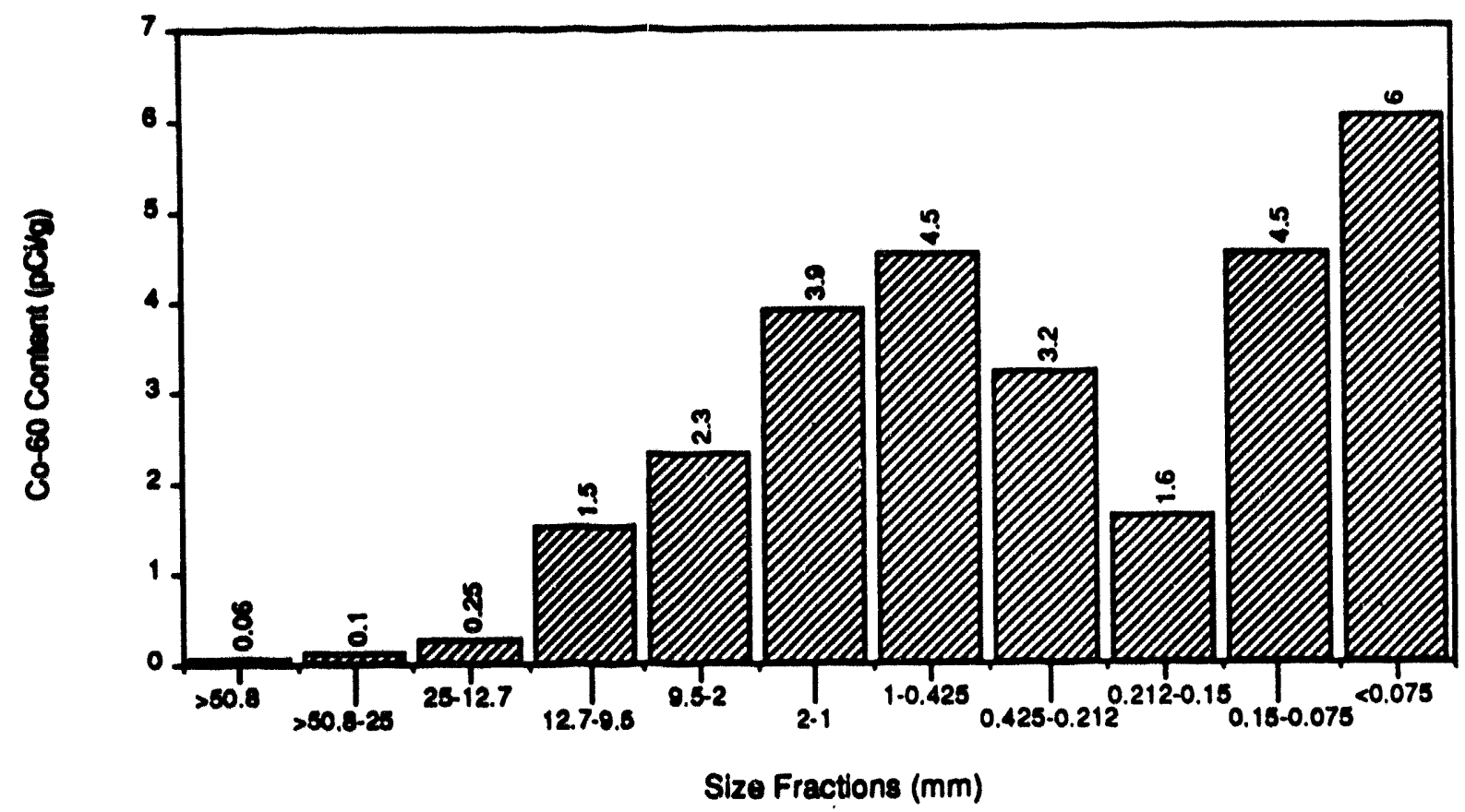

Figure 6-5b. Test \#1, Contaminant Concentrations in Each Process Pile, Cobalt-60 Gamma ipectrometry.

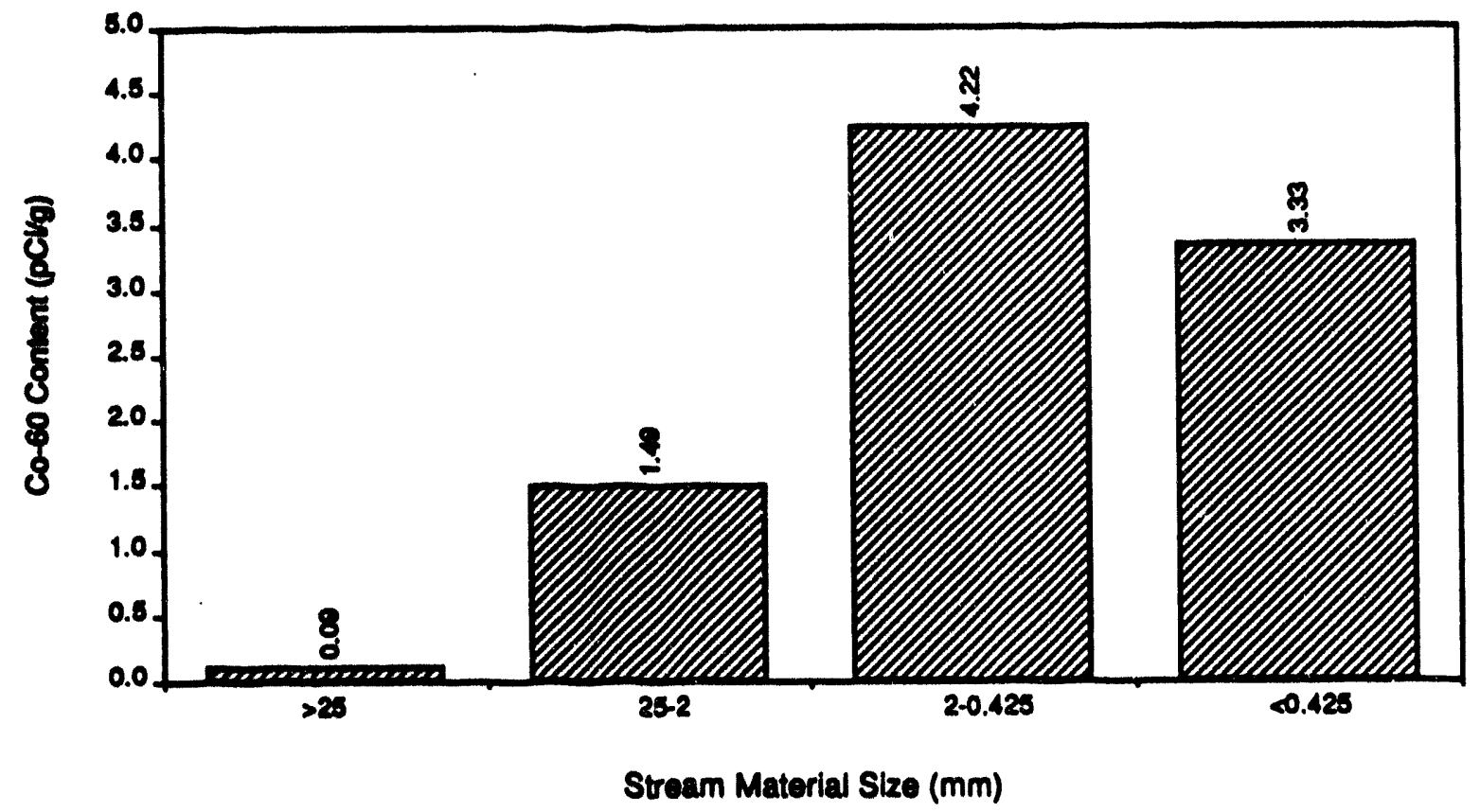

OENM112803-K 
Although test performance levels were met in the coarse soil fraction, uranium concentrations were still as high as $284 \mathrm{pCl} / \mathrm{g}$ in material up to $2 \mathrm{~mm}$ in diameter and as $\mathrm{high}$ as $149 \mathrm{pCi} / \mathrm{g}$ in the 9.5- to 2-mm fraction of material. This is most likely the result of the green material not breaking down completely.

Process effluent samples were filtered using a $0.45-\mu \mathrm{m}$ filter and analyzed by an onsite laboratory. These results are shown in Table 6-10. Results are shown for the two main processing periods in Test \#l and are comparable. The values for uranium-238 in filtered effluent $(24.2$ and $34.4 \mathrm{mg} / \mathrm{L}$ ) indicate a potential solubility problem that could affect the treatment of water for recycling.

Most contaminants were removed from the water after filtering, but uranium concentrations were still as high as $34 \mathrm{mg} / \mathrm{L}$ (purgewater acceptance standards are $0.59 \mathrm{mg} / \mathrm{L}$ for total uranium). This indicated that in spite of previous laboratory tests where uranium was not found in the water (Gerber et al. 1991), in this field test some of the uranium could not be flitered out of the process effluent. Therefore, precipitation or ion exchange water may be required.

\subsection{JUNE 29 PROCESSING RESULTS}

A final run for Test $\# 1$ was made on June 29, 1993, in which about 0.5 ton of soil was processed to clean out the hopper and trommel. Prior to processing, the trommel angle was lowered to 0 deg to increase the retention time in the tromme1. In this run, there was progress made in breaking up the green material. A few flakes of green matertal remained in the 25- to 2-mm process stream, but it was greatly reduced from previous runs. The $2-$ to $0.425-\mathrm{mm}$ solls still contained radioactivity in the range shown in Table 6-7. Samples from this run were collected, and particle size analyses were performed by an onsite laboratory. No other analyses were performed for this run.

Increasing trommel retention time resulted in better breakdown of particles in the trommel, as shown by $<0.10 \%$ of the particles $<2 \mathrm{~mm}$ in the 25- to 2-mm pile (Table 6-11), as compared 1.1\% (Table 6-6). Al so seen was an increase in the amount of fines in the 2- to $0.425-\mathrm{mm}$ p1le, where over $25 \%$ of the particles were smaller than $0.425 \mathrm{~mm}$.

The green matertal was not completely broken down. In the 25- to 2-mm fraction, it was possible to visually identify and physically separate the green material that did not break down in the trommel from the individual pieces of gravel. When this was done in the field, the resulting gravels showed radioactivity levels below background levels $(500 \mathrm{dpm})$ and activity levels for the green materlal by itself were in the ranges shown in Table 6-7.

Addition of water sprays to flush the $0.425-\mathrm{mm}$ screen or decreasing the screen angle may be needed to break down green particles between 2 and $0.425 \mathrm{~mm}$ in size. About $7 \%$ of the $<0.425-\mathrm{mm}$ material going to the fractionation tanks was silightly larger than the desired size fraction. 
DOE/RL-93-96, Rev. 0

Table 6-10. Filtered Screening Analyses of Processed Effluent Samples Collected for Test \#1. (Serne et al. 1993).

\begin{tabular}{|c|c|c|}
\hline Samplë & June 23 Processing & June 24-25 Processing \\
\hline $\begin{array}{l}\text { Constituent } \\
\text { Aluminum } \\
\text { Boron } \\
\text { Barium } \\
\text { Calctum } \\
\text { Chromium } \\
\text { Copper } \\
\text { Iron } \\
\text { Potassium } \\
\text { Magnesium } \\
\text { Manganese } \\
\text { Sodium } \\
\text { Silicon } \\
\text { Strontium } \\
\text { Zirconium }\end{array}$ & $\begin{array}{l}(\mathrm{mg} / \mathrm{L}) \\
0.27 \\
3 \\
0.03 \\
7.8 \\
0.075 \\
0.014 \\
0.44 \\
2.5 \\
1.37 \\
0.007 \\
90 \\
3.2 \\
0.035 \\
0.016\end{array}$ & $\begin{array}{c}(\mathrm{mg} / \mathrm{L}) \\
0.325 \\
3.0 \\
0.03 \\
7.5 \\
0.098 \\
0.015 \\
0.43 \\
1.9 \\
0.99 \\
0.008 \\
114 \\
3.2 \\
0.032 \\
0.012\end{array}$ \\
\hline $\begin{array}{l}\text { Urani um-238 } \\
\text { Uranium-235 }\end{array}$ & $\begin{array}{l}24.2 \\
0.184\end{array}$ & $\begin{array}{c}34.4 \\
0.297 \\
\end{array}$ \\
\hline $\begin{array}{l}\mathrm{F}^{\circ} \\
\mathrm{Cl}^{-} \\
\mathrm{NO}_{3}^{-} \\
\mathrm{SO}^{2-} \\
\mathrm{HCO}_{3}^{-}\end{array}$ & $\begin{array}{c}0.79 \\
5.4 \\
3.9 \\
24.1 \\
175 \text { (est) } \\
\end{array}$ & $\begin{array}{c}3.2 \\
3.6 \\
4.4 \\
32.3 \\
210 \text { (est) } \\
\end{array}$ \\
\hline Total organic compounds & 2.85 & 3.95 \\
\hline $\begin{array}{l}\text { Cations } \\
\text { Calctum } \\
\text { Potassium } \\
\text { Magnesium } \\
\text { Sodium } \\
\mathrm{UO}_{2} \\
\text { Antons } \\
\mathrm{F}^{\circ} \\
\mathrm{Cl}^{\circ} \\
\mathrm{NO}_{3}{ }^{-} \\
\mathrm{SO}_{4}{ }^{2-}\end{array}$ & $\begin{array}{c}\text { (meq/L) } \\
0.39 \\
0.064 \\
0.115 \\
3.869 \\
0.179 \\
\\
\\
0.042 \\
0.152 \\
0.063 \\
0.502\end{array}$ & $\begin{array}{c}\text { (meq/L) } \\
0.375 \\
0.049 \\
0.082 \\
4.935 \\
0.255 \\
\\
\\
0.168 \\
0.102 \\
0.071 \\
0.673 \\
\end{array}$ \\
\hline $\mathrm{pH}$ & 8.07 & 8.19 \\
\hline
\end{tabular}

Except as noted, analyses are ICP for metals and ion chromatography (IC) for anions. A $0.45-\mu \mathrm{m}$ filter was used. 
Table 6-11. Test \#1, June 29 Run, Wet-Sleved Analyses

for Processed Soll Fractions (Percent

by Weight). (Serne et al. 1993)

\begin{tabular}{|l|c|c|}
\hline \multicolumn{1}{|c|}{ Fraction $(\mathrm{mm})$} & 25 to $2 \mathrm{~mm}$ & 2 to $0.425 \mathrm{~mm}$ \\
\hline 25 to 13 & 92.45 & 0.00 \\
13 to 9.5 & 5.76 & 0.00 \\
9.5 to 2 & 1.69 & 0.75 \\
2 to 1 & 0.05 & 12.33 \\
1 to 0.425 & 0.01 & 62.50 \\
0.425 to 0.212 & 0.01 & 22.80 \\
0.212 to 0.150 & 0.00 & 1.11 \\
0.150 to 0.075 & 0.00 & 0.52 \\
$<0.075$ & 0.03 & 1.31 \\
\hline
\end{tabular}

Bold indicates size fraction that should be in the pile.

\subsection{ATTRITION SCRUBBING}

Attrition scrubbing 1aboratory tests were conducted to determine the viability of using this process to further break down the green particles. Tests were conducted using a laboratory-scale attrition scrubber that simulates a commercial unit (Freeman et al. 1993). It has countercurrent impellers that rotate at a selected speed and time to determine energy input requirements. Based on 100 Area tests, additional fines are created in the attrition scrubbing process.

Table 6-12 compares particle size distribution for three tests conducted using soll samples collected from the 2 to $0.425-\mathrm{mm}$ processed material. These are dry-screened, wet-screened, and attrition-scrubbed followed by wet screening. Table 6-12 shows significantly more fine solls after attrition scrubbing and less coarse material than for the wet- or dry-sieved material, indicating that particles were broken down using the scrubber.

Table 6-13 and Figures 6-6a, 6-7a, and 6-8a show that following scrubbing, contaminant concentrations were much lower in each of the wetsieved stze fractions above $0.212 \mathrm{~mm}$. Calculated concentrations of uranium-238, uranium-235, and cobalt-60 representative of each process pile are shown in Figures $6-6 b, 6-7 b$, and $6-8 b$. Values shown were calculated considering the activity levels in each fraction of solls before and after attrition scrubbing (Tables 6-13) and the size distribution of solls for each process pile (Table 6-6).

The results of the attrition scrubbing test conducted in the laboratory indicate that the addition of a commercial attrition scrubber to the soil washing system would provide the sufficient energy to treat the 2- to $0.425-\mathrm{mm}$ material such that it would meet the test objectives for solls containing the green material. Modifications to the trommel and the secondary screen in Test $* 2$ provided additional information regarding treatment of solls containing the green material. 
Table 6-12. Test \#1 Size Distribution of Dry-Sieved, Wet-Sieved, and Attrition-Scrubbed/Wet-Sieved Soil Samples from the 2- to 0.425-mm Process Pile (Percent by Weight). (Serne et al. 1993)

\begin{tabular}{|l|c|c|c|}
\hline Fraction (mm) & Wet Sieved & Dry Sieved & Attrition/Wet Sieved \\
\hline$>50.8$ & 0.00 & 0.00 & 0.00 \\
50.8 to 25.4 & 0.00 & 0.00 & 0.00 \\
25.4 to 12.7 & 0.00 & 0.00 & 0.00 \\
& 0.00 & 0.00 & 0.00 \\
12.5 to 9.5 & 2.53 & 0.65 & 0.41 \\
9.5 to 2 & 20.27 & 10.87 & 9.91 \\
2 to 1 & 62.24 & 66.06 & 62.0 \\
1 to 0.425 & 11.63 & 20.38 & 0.08 \\
0.425 to 0.212 & 0.52 & 0.70 & 0.43 \\
0.212 to 0.15 & 0.43 & 0.53 & 13.68 \\
0.15 to 0.075 & 2.37 & 0.83 & \\
$<0.075$ & & \\
\hline
\end{tabular}

Bold indicates size fraction that should be in the pile.

Table 6-13. Size Distribution of Radiochemical Isotopes After Attrition Scrubbing, Test \#1 (Serne et al 1993).

\begin{tabular}{|l|c|c|c|c|}
\hline Fraction (mm) & $\begin{array}{c}\text { Uranium-238 } \\
(\mathrm{pC} i / g)\end{array}$ & $\begin{array}{c}\text { Uranium-235 } \\
(\mathrm{pC} \mathrm{g} / \mathrm{g})\end{array}$ & $\begin{array}{c}\text { Cobalt-60 } \\
(\mathrm{pCi} / \mathrm{g})\end{array}$ & $\begin{array}{c}\text { Cesium-137 } \\
(\mathrm{pC} \mathrm{i} / \mathrm{g})\end{array}$ \\
\hline 9.5 to 2 & 33.7 & 4.1 & 5.37 & 5.05 \\
2 to 1 & 28.1 & 2.8 & 0.97 & 0.70 \\
1 to 0.425 & 50.8 & 6.3 & 0.90 & 0.46 \\
0.425 to 0.212 & 35.4 & 3.8 & 1.54 & 1.68 \\
0.212 to 0.15 & 75.2 & 10.4 & 6.68 & 3.92 \\
0.15 to 0.075 & 190 & 14.0 & 19.9 & 14.9 \\
$<0.075$ & 777 & 103 & 8.82 & 7.47 \\
\hline
\end{tabular}

In areas of the pond where the green layer is intact and undisturbed, it may be appropriate to selectively extract this material and send it directiy to disposal. Since it is already concentrated in a distinct layer, volume reduction of this material is less likely by processing it in a full-scale system. 
Figure 6-6a. Test \#1 Distribution of Uranium-238 by Particle Size, Before and After Attrition Scrubbing. (Serne et al. 1993).

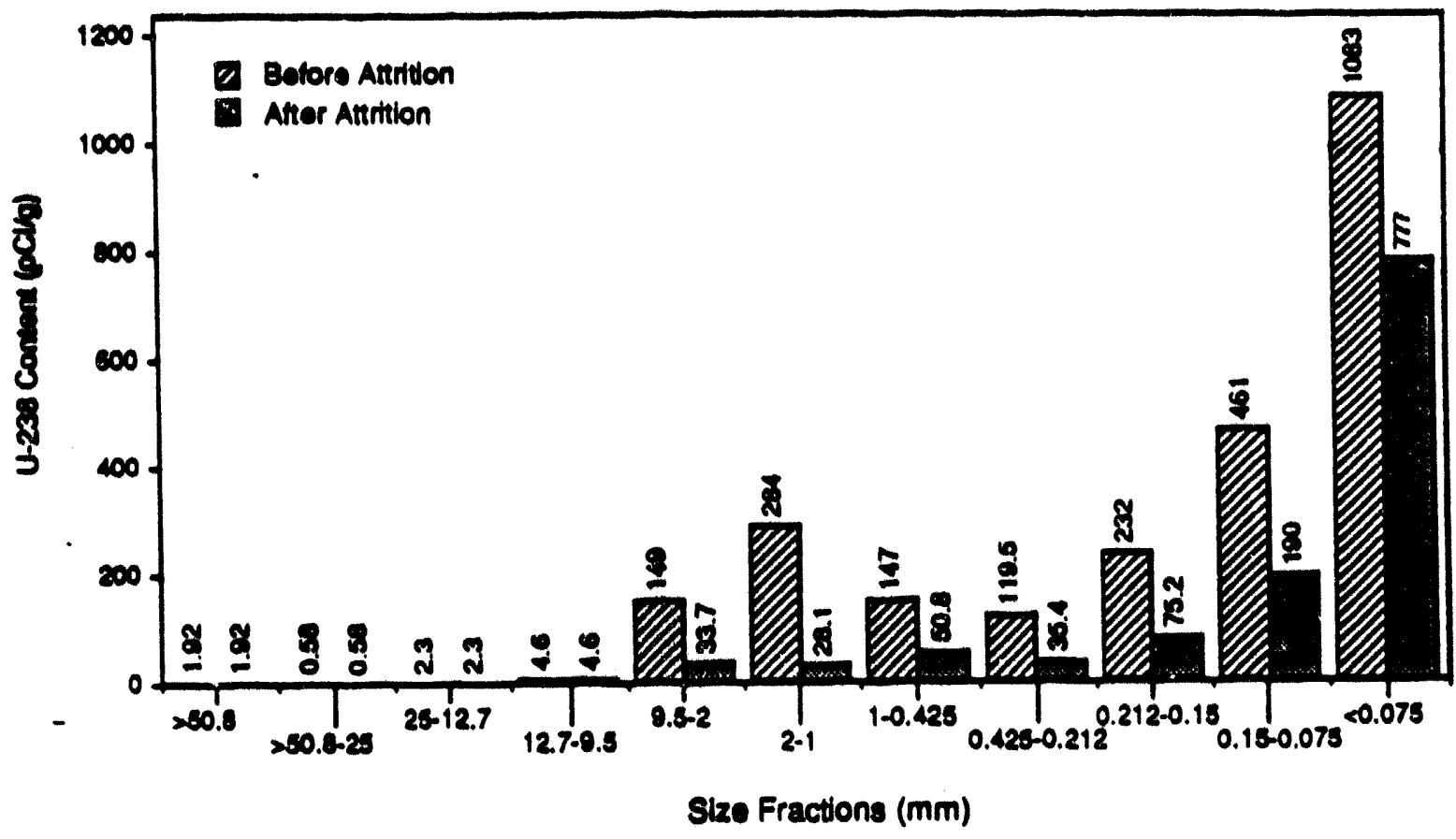

Figure 6-6b. Test \#1 Uranium-238 Levels in Each Process Pile Size Fraction, Before and After Attrition Scrubbing.

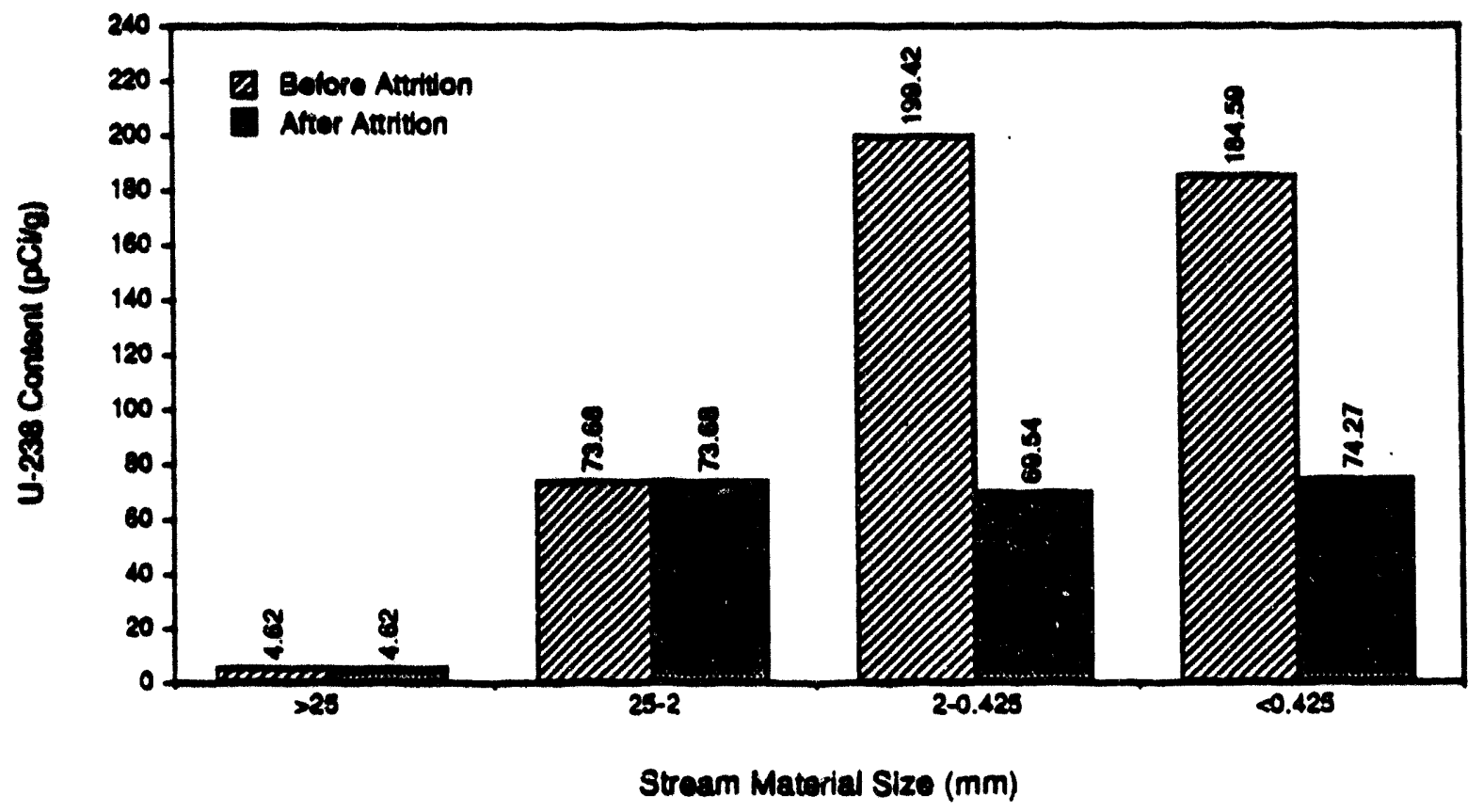

aEMmass 
Figure 6-7a. Test \#1 Distribution of Uranium-235 by Particle Size. Before and After Attrition scrubbing. (Serne et al. 1993).

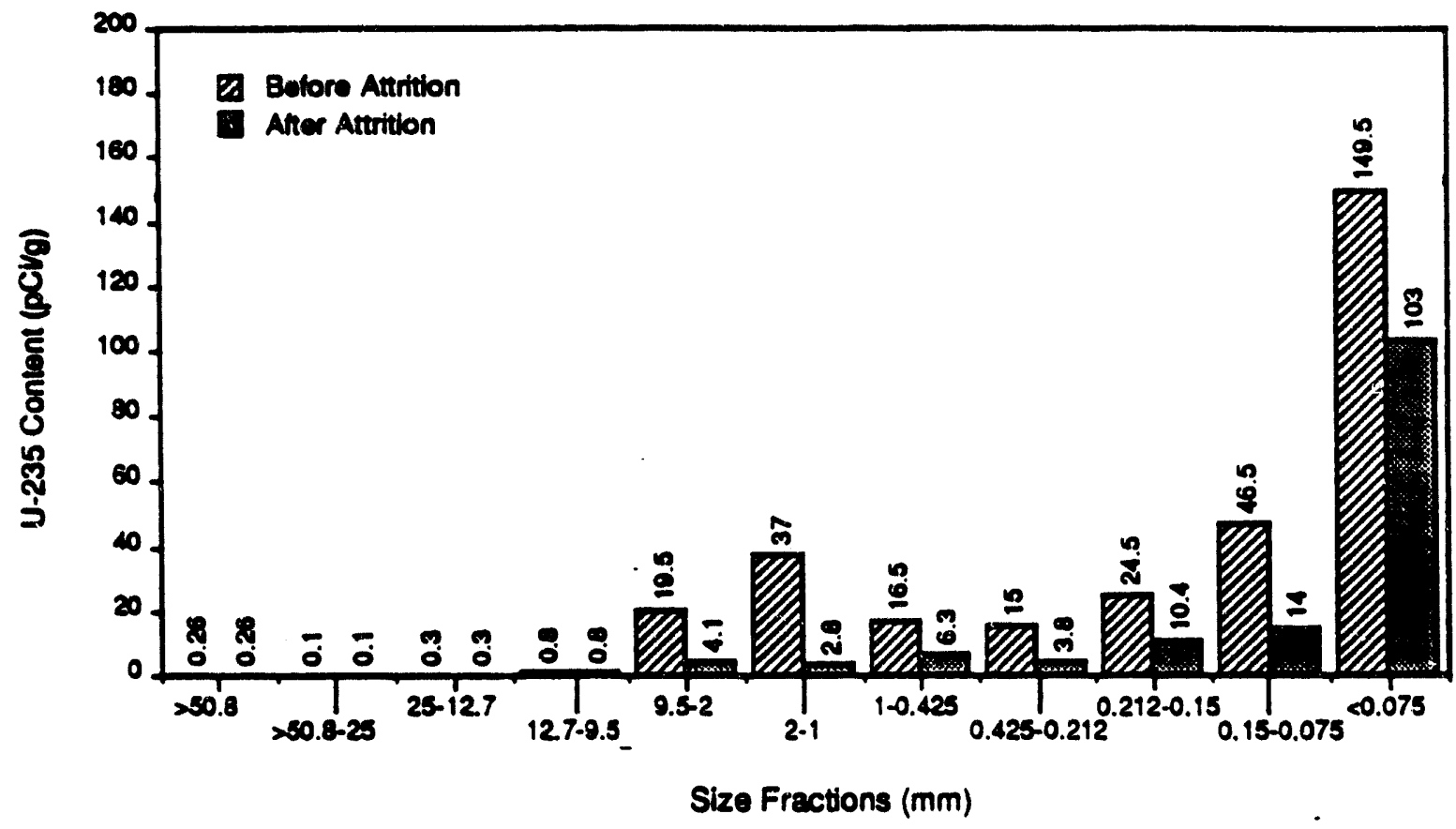

Figure 6-7b. Test \#1 Uranium-235 Levels That Would Be in Each Process Pile Size Fraction, Before and After Attrition Scrubbing.

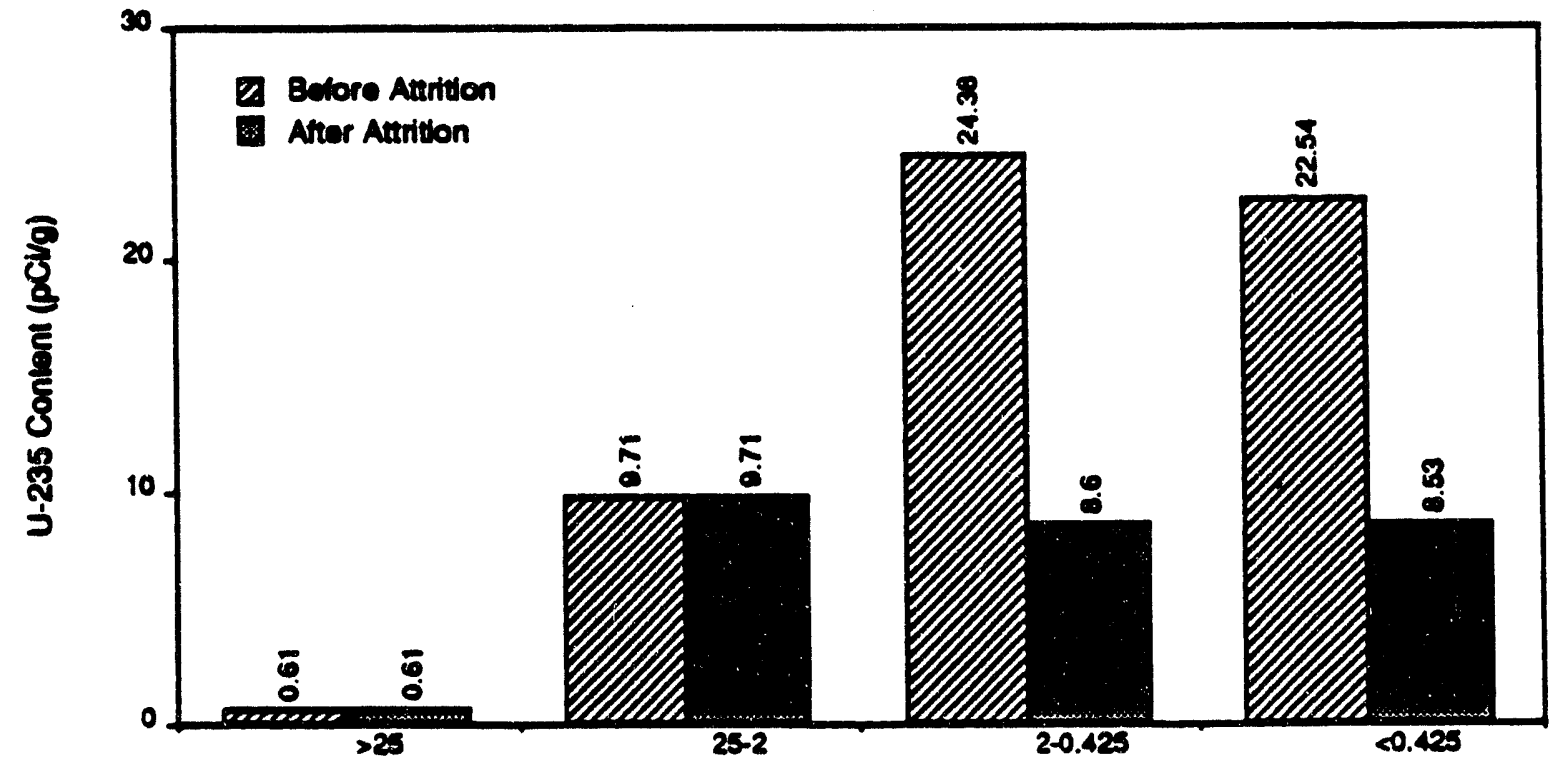

Stream Material Size (mm)

GEMME.6 
DOE/RL-93-96, Rev. 0

Figure 6-8a. Test \#1 Distribution of Cobalt-60 by Particle Size, Before and After Attrition Scrubbing. (Serne et a1. 1993)

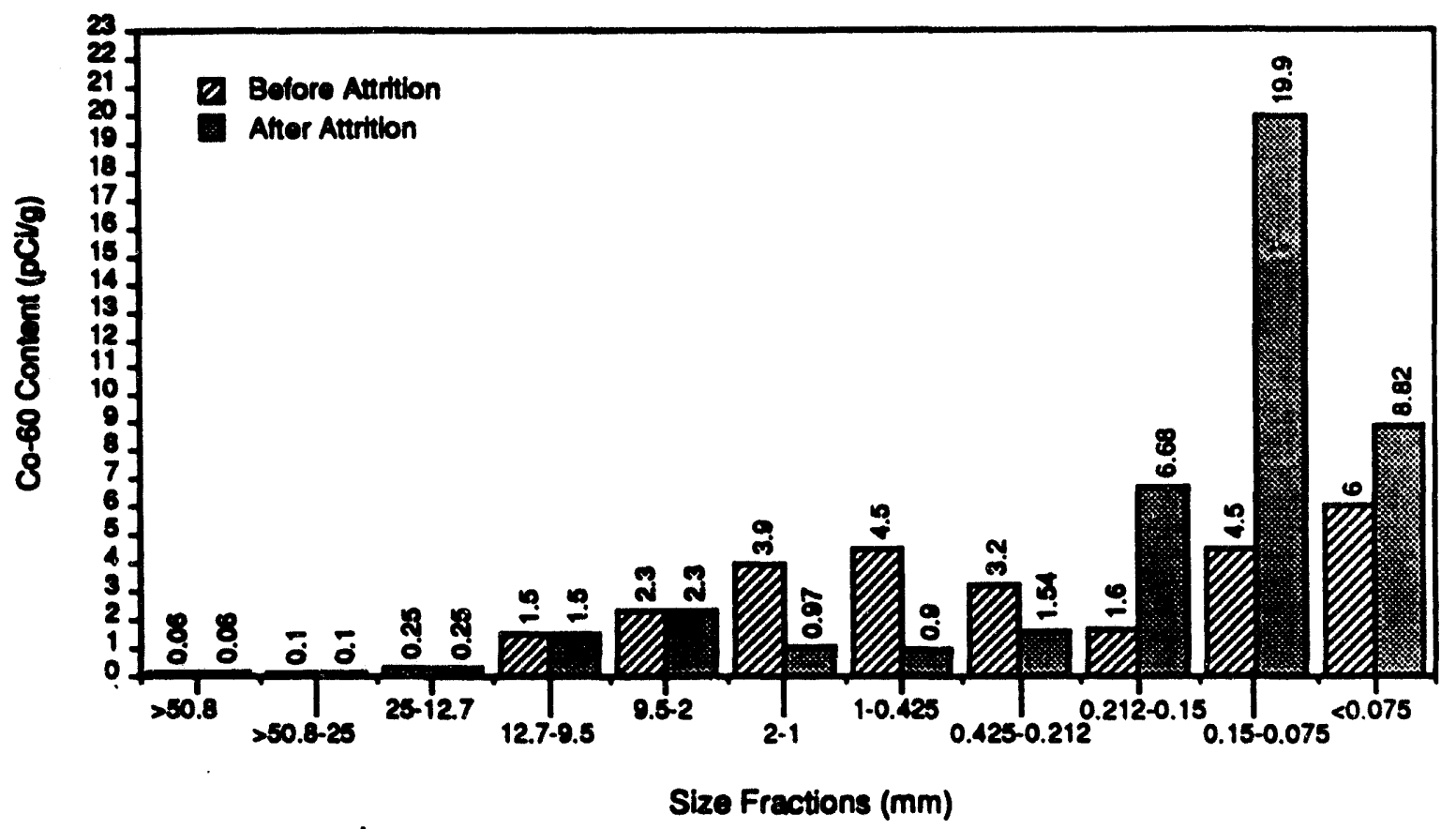

Figure 6-8b. Test \#1 Cobalt-60 Levels That Would Be in Each Process Pile Size Fraction, Before and After Attrition Scrubbing.

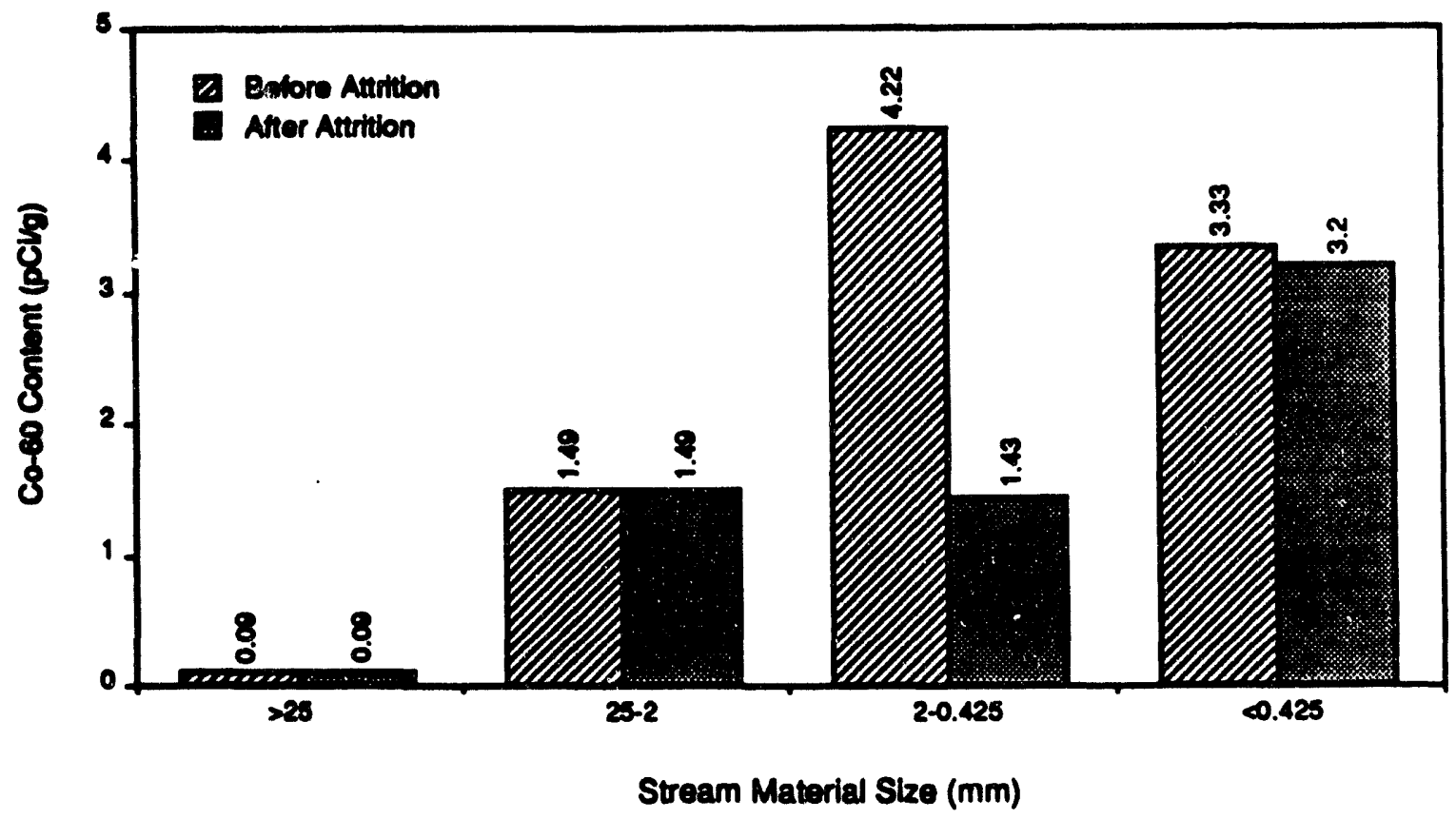

GEMM112503-J 


\subsection{DATA DISCREPANCIES}

Some differences between offsite laboratory results and onsite PNL gamma spectrometry and XRF results should be mentioned here. Almost without exception, offsite laboratory analys is of metals and radionuclides in the feed soils and in the processed streams showed higher concentrations than gamma spectrometry or XRF analyses conducted onsite for the same constituents. In both analytical laboratories, instruments were calibrated daily to a known standard.

One explanation for the differences may be that processed soils were wet sieved in the PNL laboratories and more of the uranium contaminants solubilized into the water used for wet sieving. Another potential explanation may be that in spite of efforts to obtain representative samples and duplicate samples for the laboratories, there was a spatial variability in the samples. A third possible explanation is that the samples sent to offsite laboratories may be biased because the full-size range of material may not fit into the sample bottles. As a result, oversize material that had been excluded was not accounted for. This is particularity true for the feed soils.

Another difference noticed was between activity levels for uranium-238 calculated from XRF measurements and uranium-238 analyses using gamma spectrometry. The value derived through XRF analysis is 2.2 times higher than that from gamma spectrometry. Because XRF analyses are closer to offsite laboratory results and because uranium is primarily an alpha emitter with gamma emissions and gamma measurements are less sensitive, XRF is likely the more accurate of the two. Investigations into these discrepancies are further addressed by Serne et al. (1993).

Another noted discrepancy in the data was that the concentration of uranium isotopes in feed soils was higher than the concentration in the processed soil fractions. The reason for this was that much of the uranium remained in the effluent. A rough mass balance illustrates this.

The concentration of uranium (Table 6-8) was $791 \mathrm{pCi} / \mathrm{g}$ in the $25-$ to 2-mm fraction, $650 \mathrm{pCi} / \mathrm{g}$ in the 2- to $0.425-\mathrm{mm}$ fraction, and $329 \mathrm{pCi} / \mathrm{g}$ for soils $<0.425 \mathrm{~mm}$. A weighted average of these comes out to $625 \mathrm{pCi} / \mathrm{g}$ based on the distribution in Figure 6-2b. The concentration of uranium in the $<25-\mathrm{mm}$ feed soils was $1,802 \mathrm{pCi} / \mathrm{g}$ (Table 6-4). The difference between feed soils and processed soils is $1,177 \mathrm{pCi} / \mathrm{g}$, rounded to $1,200 \mathrm{pCi} / \mathrm{g}$. Since approximately 4.3 tons of $<2-\mathrm{mm}$ soil was processed in Test \#1 (Figure 6-1), this gives a total radioactivity level of $5.26 \mathrm{EO} \mathrm{pCi}$ that is not accounted for and that should have accumulated in the process effluent.

Approximately $91,000 \mathrm{~L}$ of effluent was processed in Test \#1. After processing, unfiltered effluent contained approximately $40,000 \mathrm{pCi} / \mathrm{L}$ of uranium activity (Table 6-8). Multiplied, this is $3.6 \mathrm{EO}$ pCi of uranium, which is within the same order of magnitude as the difference in soil activity levels before and after processing. 
DOE/RL-93-96, Rev. 0

\subsection{RECOMMENDATIONS FOR TEST *2}

Based on the activities of Test \#l and evaluation of the results of sampling done during the test, the following items were considered before the start of Test \#2.

1. The original scope of this test as defined in the test plan was to treat soils that were not contaminated with the green material. These soils represent the majority of the soils in the 300-FF-1 Operable Unit and must be processed during Test \#2.

2. The system needs to be modified so it can be fed with smaller equipment. This will provide better control of the material going onto the primary screen allowing for higher screen efficiency and better rinsing of the oversize material.

3. The system needs to be modified such that it can be operated continuously. This will be accomplished by the modification for the use of smaller feed equipment and adequate dust control. measures.

4. The operating parameters for the trommel need to be modified to better treat solls containing the green material. As with Test $\# 1$, the slope of the trommel should remain at 0 deg for soils with the green material. The speed should be increased from 5 to 7 rpm. These modifications are proposed to promote the breakdown of the green particles.

5. The secondary screen and its operating parameters need to be modified in an attempt to effectively treat soils containing the green material. The system modifications include installation of sprays over the secondary screen. The slope of the secondary screen should be changed to increase the retention time of oversize material on the screen. The speed of the secondary screen should be slowed down to also increase the retention time. These changes are proposed to increase the efficiency of the screen and to enhance the breakdown of the green particles. 


\subsection{TEST \#2}

Test \#2 was conducted September 8 and 9, 1993. The purpose of Test \#2 was to process soils free of the green material and to assess system modifications recommended in Section 6.6. Soils processed on September 8 were collected from three different areas of the north pond (see Figure 1-2). Soils processed on September 9 were collected from piles on the southwest portion of the north pond, near the location for Test \#1. A summary of Test \#2 activities is shown in Table 7-1.

Table 7-1. Summary of Test \#2 Activities.

\begin{tabular}{|c|c|c|c|}
\hline Date & $\begin{array}{c}\text { Tons } \\
\text { Processed }\end{array}$ & Material & $\begin{array}{c}\text { Approximate } \\
\text { Processing } \\
\text { Time (min) }\end{array}$ \\
\hline $09 / 08 / 93$ & 15 & $\begin{array}{c}\text { Contaminated soils free of } \\
\text { any visible green particles }\end{array}$ & 135 \\
\hline $09 / 09 / 93$ & 5 & $\begin{array}{c}\text { Soils contaminated with } \\
\text { green particles }\end{array}$ & 60 \\
\hline
\end{tabular}

Prior to conducting Test \#2, field radiological measurements were made using a GM probe to identify those locations in the ponds without the green material. Green material was found in each of the soil piles along the west side of the north process pond, with radioactivity levels ranging from 150 to $1,200 \mathrm{dpm}$ above background $(500 \mathrm{dpm})$. No green material was observed on the north-central end and along the east side of the north process pond. Radioactivity of these soils was measured at near-background levels (500 dpm) and were chosen for the September 8 feed. A front-end loader was used to stockpile these soils prior to processing.

Field measurements of soils processed on September 8 showed that radioactivity levels were near background and well below test performance levels. Therefore, the goal of processing the soils was not to meet test performance levels, but to determine if, or by how much, radioactivity and metal concentrations could be reduced using the modified EPA system. RI Phase I investigations (DOE-RL 1993c) indicate that the soils processed are representative of about $75 \%$ of the contaminated soils in the north and south process ponds.

The system was modified for Test \#2 so a small front-end loader could be used to feed it. Modifications involved mounting the $150-\mathrm{mm}$ grizzly on a shorter, smaller hopper and adding a conveyor to move soils from this hopper to the 25-mm screen (Figure 7-1). With these modifications, less water was required for dust control and the system operated continuousiy. 
Figure 7-1. System Configuration/Material Balance for Test \#2.

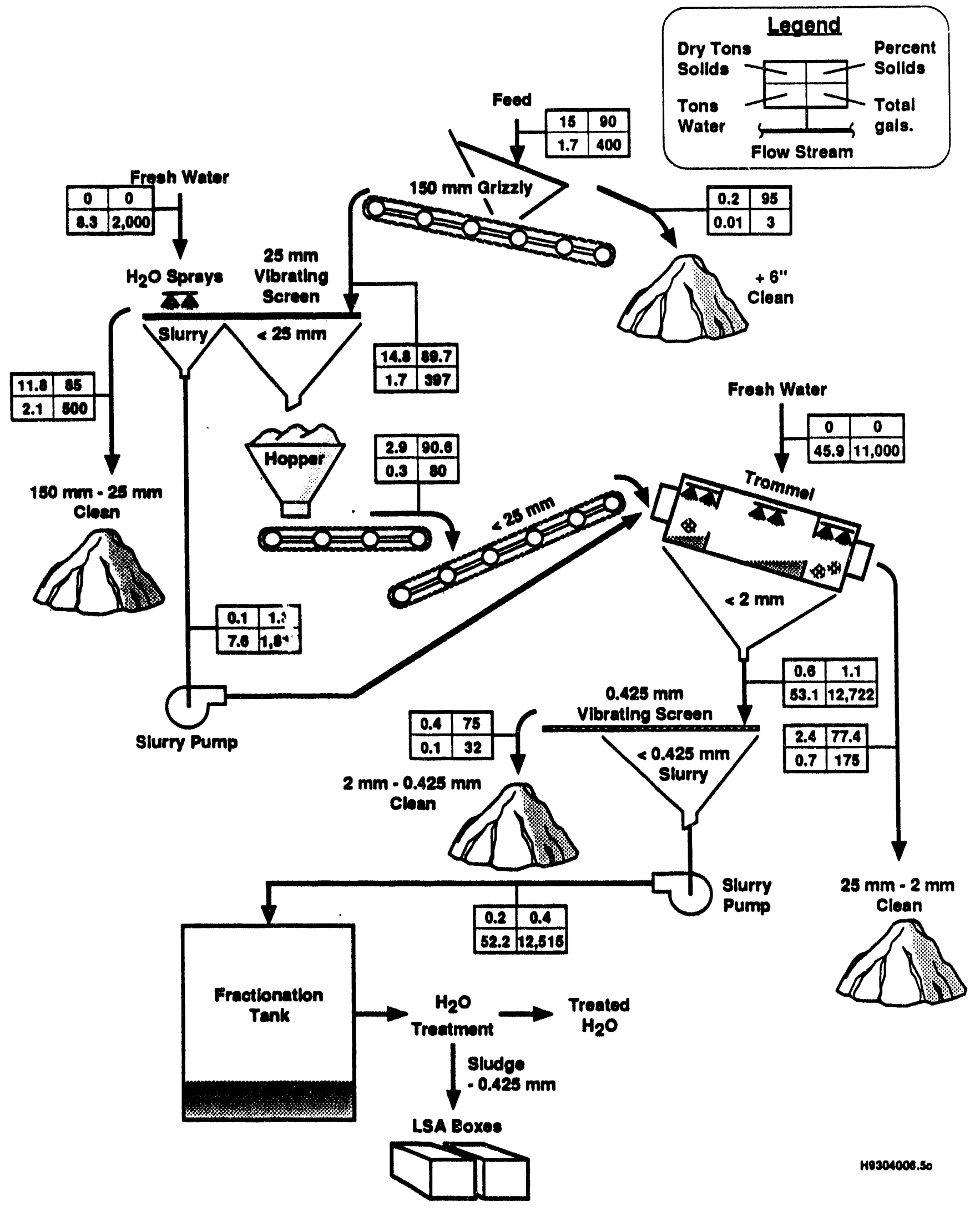


As was to be expected with untested components in the system, several problems were encountered that had to be worked out. The head pulley on the conveyor was adjusted to tighten the belt. The new operator was unfamiliar with the system and had trouble feeding the material without jamming the conveyor, and the chain drive on the conveyor came off. After these problems were resolved, the system ran smoothly.

Although the system was modified to operate continuously, travel and feed time for the front-end loader and limitations on the feed rate of the 25$\mathrm{mm}$ shaker screen contributed to lower feed rates. It was not possible to improve the feed rate in a timely manner. However, except for limiting the amount of material processed, this did not impact the test results.

The system configuration and a mass balance for September 8 processing are shown in Figure 7-1. Operating parameters and flow measurements are shown in Table 7-2. HEIS numbers of soil and effluent samples taken on September 8 are shown in Table 4-2. Sections 7.1 and 7.2 are results from processing on September 8 only.

On September 9, additional testing was performed on soils containing the green material. Several of the operating parameters were changed in an effort to enhance the breakdown of the green material. However, the changes resulted in limited success, and no samples or analyses except for field measurements were obtained.

\subsection{FEED SOILS AND FRESH WATER}

\subsubsection{Particle Size Distribution}

The particle size distribution of feed soils used in Test \#2 is shown in Table 7-3 and Figure 7-2a. The corresponding percent of soils expected in each process pile is shown in Figure $7-2 b$. More than $96 \%$ of the soil particles were $>0.425 \mathrm{~mm}$. This was more coarse material than in Test \#1 where about $88 \%$ of the soil particles were $>0.425 \mathrm{~mm}$ (see Figure 6-2b).

\subsubsection{Analytical Results}

Laboratory analyses showing the average concentration and standard deviation for chemical and radiochemical contaminants for feed soils and water are shown in Table 7-4. As expected based on RI Phase I data (DOE-RL 1993C), chemical and radiochemical constituents in feed soils for Test \#2 were below test performance levels prior to processing. TCLP analyses (Appendix B.2) were also below regulatory levels of concern. effluent.

Clean water fed to the system was analyzed for comparison with process 
Table 7-2. Equipment Operating Parameters and Flow Measurements for Test \#2.

\begin{tabular}{|c|c|c|c|c|}
\hline Component & \multicolumn{2}{|c|}{ Parameter } & September 8 Processing & September 9 Processing \\
\hline Grizzly & \multicolumn{2}{|c|}{$\begin{array}{l}\text { Opening Between Bars } \\
\text { Estimated feed Rate }\end{array}$} & $\begin{array}{l}150 \mathrm{~mm} \\
6.7 \mathrm{tons} / \mathrm{hr}\end{array}$ & $\begin{array}{l}150 \mathrm{~mm} \\
7.5 \mathrm{tons} / \mathrm{hr}\end{array}$ \\
\hline \multirow[t]{3}{*}{$\begin{array}{l}\text { Primary } \\
\text { Screen }\end{array}$} & \multicolumn{2}{|c|}{$\begin{array}{l}\text { Screen Opening size } \\
\text { screening Area } \\
\text { slope }\end{array}$} & $\begin{array}{l}25 \mathrm{~mm} \\
750 \text { by } 2,400 \mathrm{~mm} \\
0.0 \text { deg }\end{array}$ & $\begin{array}{l}25 \mathrm{~mm} \\
750 \text { by } 2,400 \mathrm{~mm} \\
1.5 \mathrm{deg}\end{array}$ \\
\hline & $\begin{array}{l}\text { Rinse } \\
\text { Nozzles }\end{array}$ & $\begin{array}{l}\text { Pressure } \\
\text { Flowrate } \\
\text { \& L/ton }\end{array}$ & $\begin{array}{l}2.8 \mathrm{~kg} / \mathrm{cm}^{2}\left(40 \mathrm{lb} / \mathrm{in}^{2}\right) \\
50 \mathrm{~L} / \mathrm{min}(13 \mathrm{gal} / \mathrm{min}) \\
560 \mathrm{~L} / \text { ton }(150 \mathrm{gal} / \mathrm{ton})\end{array}$ & $\begin{array}{l}\text { Moved to secondary screen } \\
\text { N/A } \\
\text { N/A }\end{array}$ \\
\hline & \multicolumn{2}{|c|}{ Estimated Feed Rate } & 6.6 tons/hr & 7.4 tons $/ \mathrm{hr}$ \\
\hline \multirow[t]{5}{*}{ Trominel } & \multicolumn{2}{|c|}{$\begin{array}{l}\text { Screen Opening size } \\
\text { Overall Dimensions } \\
\text { Rotational speed } \\
\text { slope } \\
\text { Retention (wash) Time }\end{array}$} & $\begin{array}{l}2 \mathrm{~mm} \\
1.4 \mathrm{~m} \mathrm{dia} \text {. by } 6.4 \mathrm{~m} \\
5.0 \mathrm{rp} / \\
3.0 \mathrm{deg} \\
3 \mathrm{~min}\end{array}$ & $\begin{array}{l}2 \mathrm{~mm} \\
1.4 \mathrm{~m} \text { dia. by } 6.4 \mathrm{~m} \\
7.0 \mathrm{rpm} \\
0.0 \mathrm{deg} \\
20 \mathrm{~min}\end{array}$ \\
\hline & $\begin{array}{l}\text { Initial } \\
\text { Rinse } \\
\text { Nozzles }\end{array}$ & $\begin{array}{l}\text { Pressure } \\
\text { Flowrate } \\
\approx \mathrm{gal} / \mathrm{ton} \\
\end{array}$ & $\begin{array}{l}4.2 \mathrm{~kg} / \mathrm{cm}^{2}\left(60 \mathrm{lb} / \mathrm{in}^{2}\right) \\
600 \mathrm{~L} / \mathrm{min}(160 \mathrm{gal} / \mathrm{min}) \\
27,000 \mathrm{~L} / \operatorname{ton}(7,100 \mathrm{gal} / \text { ton })\end{array}$ & $\begin{array}{l}4.2 \mathrm{~kg} / \mathrm{cm}^{2}\left(60 \mathrm{lb} / \mathrm{in}^{2}\right) \\
600 \mathrm{~L} / \mathrm{min}(160 \mathrm{gal} / \mathrm{min}) \\
36,000 \mathrm{~L} / \text { ton }(9,500 \mathrm{gal} / \text { ton })\end{array}$ \\
\hline & $\begin{array}{l}\text { Wash } \\
\text { Water } \\
\text { Nozzle }\end{array}$ & $\begin{array}{l}\text { Pressure } \\
\text { Flowrate } \\
=\mathrm{gal} / \mathrm{ton} \\
\end{array}$ & $\begin{array}{l}2.8 \mathrm{~kg} / \mathrm{cm}^{2}\left(40 \mathrm{lb} / \mathrm{in}^{2}\right) \\
60 \mathrm{~L} / \mathrm{min}(15 \mathrm{gal} / \mathrm{min}) \\
3,400 \mathrm{~L} / \text { ton }(900 \mathrm{gal} / \text { ton })\end{array}$ & $\begin{array}{l}2.8 \mathrm{~kg} / \mathrm{cm}^{2}\left(40 \mathrm{lb} / \mathrm{in}^{2}\right) \\
40 \mathrm{~L} / \mathrm{min}(10 \mathrm{gal} / \mathrm{min}) \\
3,000 \mathrm{~L} / \text { ton }(800 \mathrm{gal} / \mathrm{ton})\end{array}$ \\
\hline & $\begin{array}{l}\text { Final } \\
\text { Rinse } \\
\text { Nozzles }\end{array}$ & $\begin{array}{l}\text { Pressure } \\
\text { Flowrate } \\
\text { - gal/ton }\end{array}$ & $\begin{array}{l}2.8 \mathrm{~kg} / \mathrm{cm}^{2}\left(40 \mathrm{lb} / \mathrm{in}^{2}\right) \\
250 \mathrm{~L} / \mathrm{min}(65 \mathrm{ga} / / \mathrm{min}) \\
14,000 \mathrm{~L} / \text { ton }(3,700 \mathrm{gal} / \mathrm{ton})\end{array}$ & $\begin{array}{l}2.8 \mathrm{~kg} / \mathrm{cm}^{2}\left(40 \mathrm{lb} / \mathrm{in}^{2}\right) \\
160 \mathrm{~L} / \mathrm{min}(40 \mathrm{gal} / \mathrm{min}) \\
12,000 \mathrm{~L} / \text { ton }(3,200 \mathrm{gal} / \text { ton })\end{array}$ \\
\hline & \multicolumn{2}{|c|}{ Estimated Feed Rate } & 1.3 tons $/ \mathrm{hr}$ & 1.4 tons $/ \mathrm{hr}$ \\
\hline \multirow[t]{3}{*}{$\begin{array}{l}\text { Secondary } \\
\text { Screen }\end{array}$} & \multicolumn{2}{|c|}{$\begin{array}{l}\text { screen Opening size } \\
\text { screening Area } \\
\text { slope }\end{array}$} & $\begin{array}{l}0.425 \mathrm{~mm} \\
0.56 \text { by } 2.1 \mathrm{~m} \\
0.0 \mathrm{deg}\end{array}$ & $\begin{array}{l}0.425 \mathrm{~mm} \\
0.56 \text { by } 2.1 \mathrm{~m} \\
-0.5 \mathrm{deg}\end{array}$ \\
\hline & $\begin{array}{l}\text { Rinse } \\
\text { Nozzles }\end{array}$ & $\begin{array}{l}\text { Pressure } \\
\text { Flowrate } \\
\text { gal/ton }\end{array}$ & $\begin{array}{l}N / A \\
N / A \\
N / A\end{array}$ & $\begin{array}{l}2.8 \mathrm{~kg} / \mathrm{cm}^{2}\left(40 \mathrm{lb} / \mathrm{in}^{2}\right) \\
50 \mathrm{~L} / \mathrm{min}(13 \mathrm{gal} / \mathrm{min}) \\
18,000 \mathrm{~L} / \mathrm{ton}(4,700 \mathrm{gal} / \text { ton })\end{array}$ \\
\hline & \multicolumn{2}{|c|}{$\begin{array}{l}\text { Speed Setting }(x) \\
\text { Feed slurry Density } \\
\text { Estimated Feed Rate } \\
\text { Estimated Slurry } \\
\text { Flowrate }\end{array}$} & $\begin{array}{l}100 \\
1.1 \% \mathrm{dry} \text { solids } \\
0.3 \mathrm{ton} / \mathrm{hr} \\
410 \mathrm{~L} / \mathrm{min}\end{array}$ & $\begin{array}{l}40 \\
1.6 x \mathrm{dry} \text { solids } \\
0.3 \mathrm{ton} / \mathrm{hr} \\
280 \mathrm{~L} / \mathrm{min}\end{array}$ \\
\hline
\end{tabular}


Table 7-3. Test \#2, Wet-Sieved Size Distribution of Feed Solls. (Serne et al. 1993).

\begin{tabular}{|l|c|}
\hline \multicolumn{1}{|c|}{ Size Fraction (mm) } & \% by Wt \\
\hline$>50.8$ & 63.2 \\
50.8 to 25 & 16.8 \\
25 to 2 & 15.7 \\
2 to 0.425 & 2.9 \\
0.425 to 0.212 & 0.45 \\
0.212 to 0.15 & 0.10 \\
0.15 to 0.075 & 0.15 \\
$<0.075$ & 0.85 \\
\hline
\end{tabular}

\subsection{PROCESSED SOILS AND EFFLUENT}

\subsubsection{Separation Efficiency}

Samples collected from each of the process piles were sieved onsite. Sieve analyses for each of the process piles in Test \#2 (Table 7-5) show that the three screening units in the system performed well within normal operating parameters for this equipment.

Defining separation efficiency as the percent of material that actually passes through a screen compared to the amount available to pass through it, the following separation efficiencies for the various screens were calculated.

The 25-mm primary screen operated at almost $99 \%$ efficiency. The trommel efficiency for Test $\# 2$ was about $90 \%$, slightly lower than it was for Test $\# 1$. The difference was due to the much higher percentage of fines in Test $\# 1$ as compared to Test $\# 2$ ( $56 \%$ and $22 \%$, respectively).

The $0.425-\mathrm{mm}$ secondary screen operated at $85 \%$ efficiency for Test \#2. This is slightly higher than for Test $\# 1$. The increased efficiency is attributed to addition of water spray to help improve the separation made by . this screen. This screen experienced a certain amount of blinding off that reduced the unit's efficiency. Full-scale operations will require either a different process for separating soil particles $<0.425 \mathrm{~mm}$ (i.e., hydrocyclones or countercurrent columns) or additional vibrating screens to facilitate a schedule for the shutdown for cleaning without interrupting the processing.

Based on Tables 7-5 and 7-3, after processing in the field, approximately $98 \%$ of the solls were in the 150- to 25-mm, 25- to 2-mm, and 2to $0.425-\mathrm{mm}$ process piles. Only about $2 \%$ of the soil particles were in the $<0.425-\mathrm{mm}$ stream sent to the fractionation tanks. 
DOE/RL-93-96, Rev. 0

Figure 7-2a. Average Wet-Sieved Size Distribution of Feed Soils in Test \#2 (Percent by Weight). (Serne et al. 1993)

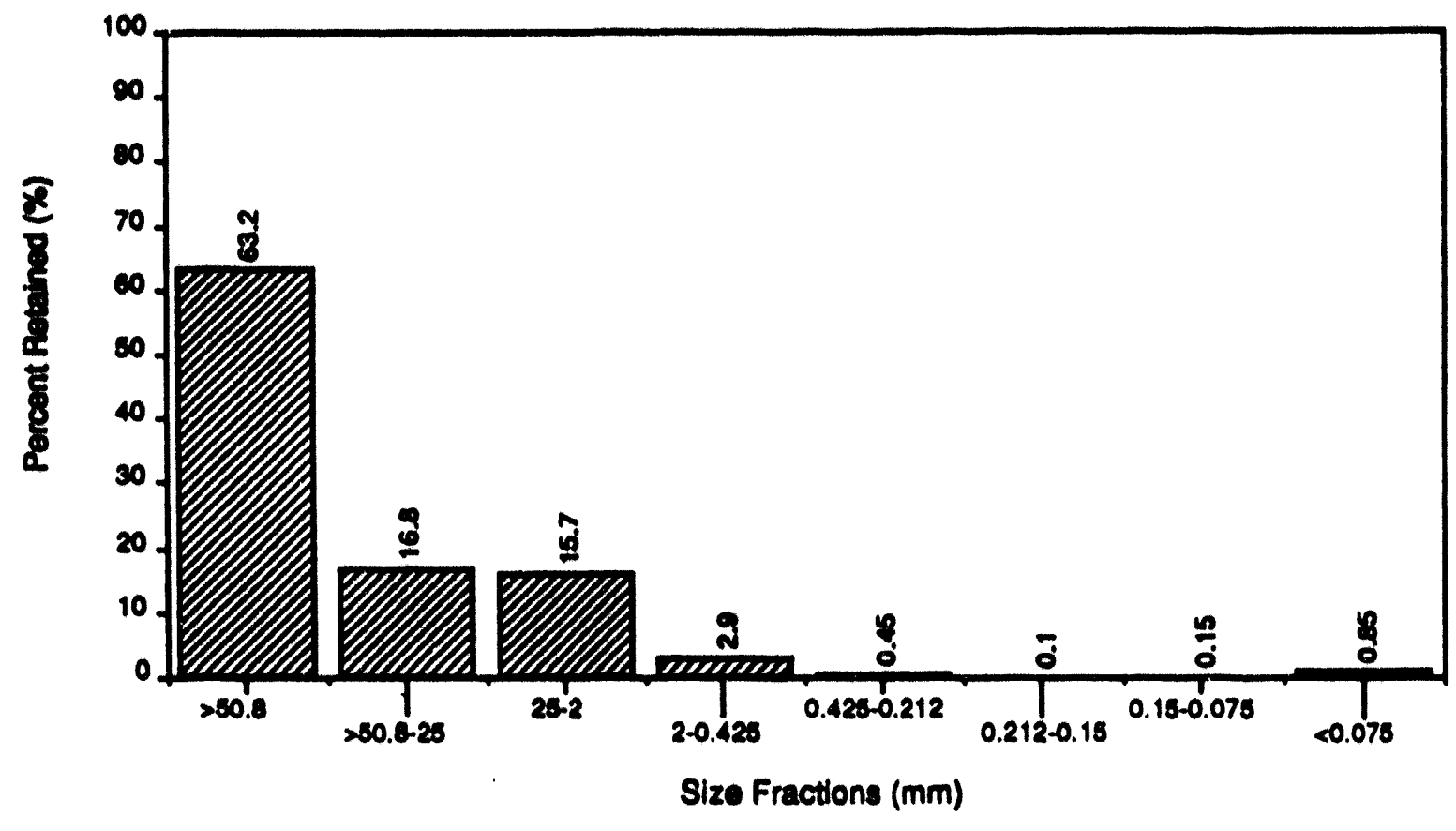

Figure 7-2b. Percent of Soils in Each Process Plle, Test \#2 (Percent by Weight).

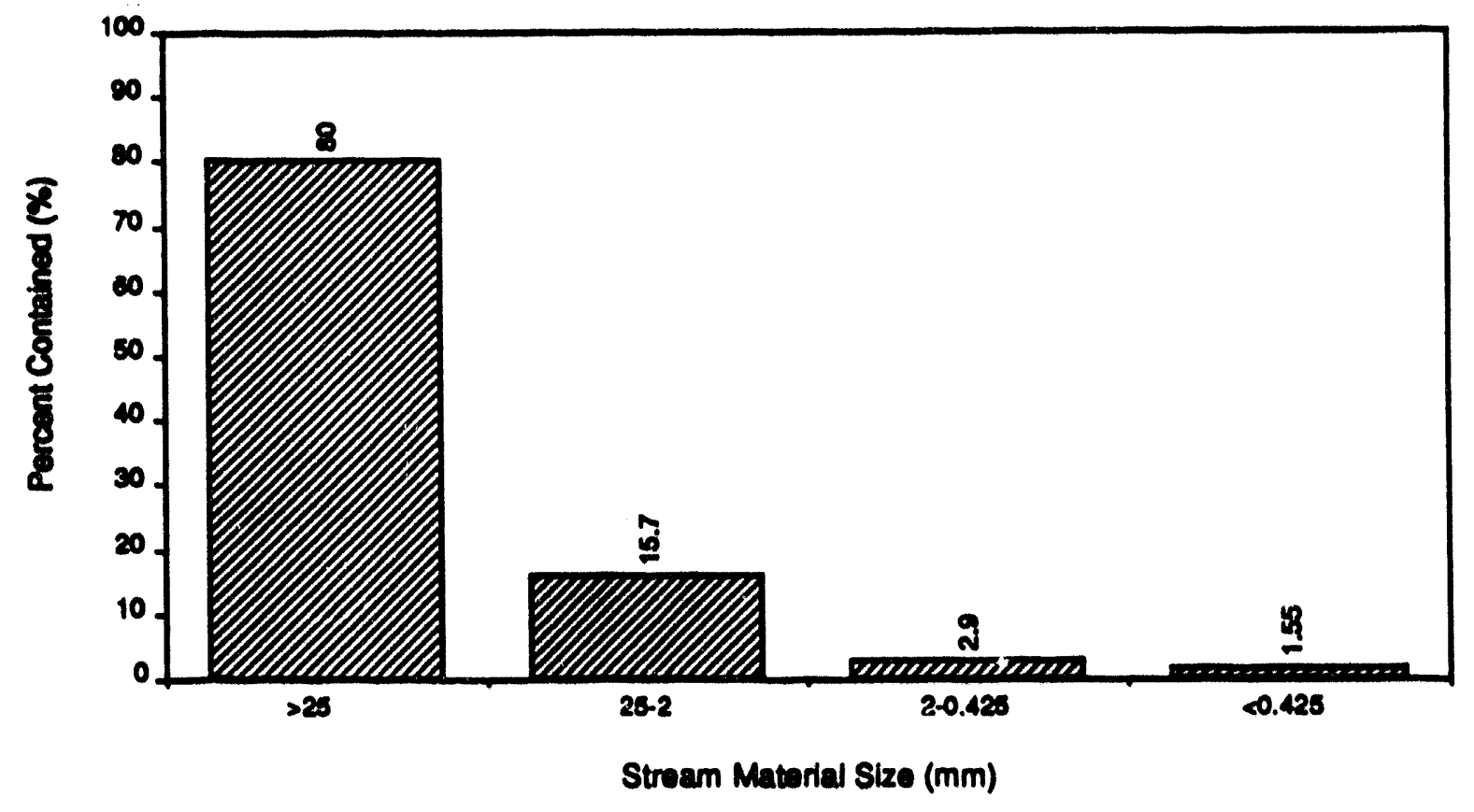

GEMMI12002-A 
Table 7-4. Test \#2, September 8, Chemical and Radiochemical Analyses of Feed Sol1s <25 $\mathrm{mm}^{\circ}$ and Feed Water (Appendix B.2).

\begin{tabular}{|c|c|c|c|c|}
\hline \multirow{2}{*}{ Semple } & \multicolumn{2}{|c|}{ Feed solls } & \multicolumn{2}{|c|}{ Water } \\
\hline & Avg & $\mathbf{S}$ & Avg & $\mathbf{s}$ \\
\hline 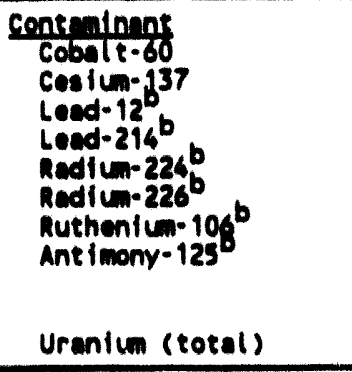 & $\begin{array}{l}(p c 1 / 9) \\
0.116 \\
0.062 \\
0.591 \\
0.475 \\
0.596 \\
0.460 \\
0.040 U \\
0.009 U \\
\\
5.506\end{array}$ & $\begin{array}{c}(\mathrm{pCl} / \mathrm{g}) \\
0.102 \\
0.020 \\
0.058 \\
0.027 \\
0.058 \\
0.065 \\
0.120 \\
0.030 \\
\\
4.162\end{array}$ & $\begin{array}{l}(p C 1 / L) \\
2.809 U \\
3.075 U \\
N A \\
N A \\
N A \\
N A \\
U \\
U \\
\\
(1 / g / L) \\
0.958\end{array}$ & $\begin{array}{l}(\mathrm{pCl} / \mathrm{l}) \\
2.144 \\
1.112 \\
\mathrm{NA} \\
\mathrm{NA} \\
\mathrm{NA} \\
\mathrm{NA} \\
\mathrm{U} \\
\mathrm{U} \\
\\
(\mu \mathrm{g} / \mathrm{L}) \\
0.391\end{array}$ \\
\hline 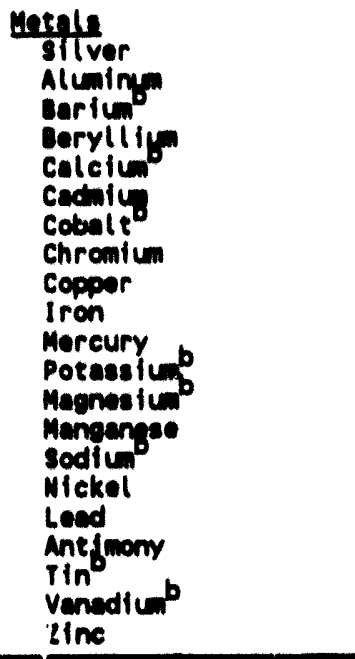 & $\begin{array}{c}(m g / k g) \\
3.6 \\
11,320 \\
119.2 \\
0.33 \\
7.880 \\
0.00 \\
12.6 \\
19.8 \\
238 \\
32,600 \\
0.17 \\
1.294 \\
6,340 \\
498 \\
446 \\
28.8 \\
5.68 \\
4.82 \\
0.00 \\
88.2 \\
70.6\end{array}$ & $\begin{array}{c}(\mathrm{mg} / \mathrm{kg}) \\
0.92 \\
2,282 \\
22.82 \\
0.10 \\
1.038 \\
0.00 \\
1.02 \\
3.66 \\
80.6 \\
1.625 \\
0.15 \\
368 \\
779 \\
73.1 \\
17.4 \\
4.79 \\
1.32 \\
2.46 \\
0.00 \\
1.72 \\
4.75\end{array}$ & $\begin{array}{l}(\mathrm{mg} / \mathrm{L}) \\
0.002 \\
0.00 \\
0.031 \\
0.00 \\
28.3 \\
0.00 \\
0.00 \\
0.00 \\
0.03 \\
0.79 \\
0.00 \\
2.20 \\
6.45 \\
0.028 \\
5.80 \\
0.00 \\
0.012 \\
0.00 \\
0.00 \\
0.0013 \\
0.010\end{array}$ & $\begin{array}{l}(\mathrm{mg} / \mathrm{L}) \\
0.002 \\
0.00 \\
0.005 \\
0.00 \\
5.76 \\
0.00 \\
0.00 \\
0.003 \\
0.031 \\
0.671 \\
0.00 \\
0.51 \\
1.46 \\
0.025 \\
2.18 \\
0.00 \\
0.015 \\
0.00 \\
0.00 \\
0.002 \\
0.009\end{array}$ \\
\hline 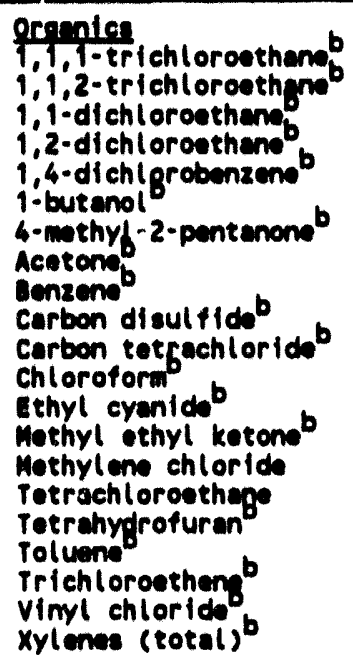 & $\begin{array}{l}M A \\
M A \\
M A \\
M A \\
M A \\
M A \\
M A \\
M A \\
M A \\
M A \\
M A \\
M A \\
M A \\
M A \\
M A \\
M A \\
M A\end{array}$ & $\begin{array}{l}M A \\
M A \\
M A \\
M A \\
M A \\
M A \\
M A \\
M A \\
M A \\
M A \\
M A \\
M A \\
M A \\
M A \\
M A \\
M A\end{array}$ & $\begin{array}{l}(m / L) \\
0.000 U \\
U \\
U \\
U \\
U \\
U \\
U \\
U \\
U \\
U \\
U \\
0.0014 U \\
U \\
0.005 U \\
U \\
U \\
0.0094 U \\
U \\
0.0001 U \\
U \\
U\end{array}$ & $\begin{array}{c}(m / L) \\
0.0012 U \\
U \\
U \\
U \\
U \\
U \\
U \\
U \\
U \\
U \\
U \\
0.0029 U \\
U \\
0.015 U \\
U \\
U \\
0.0123 U \\
U \\
0.0003 U \\
U \\
U\end{array}$ \\
\hline
\end{tabular}

- standard deviation; $U$ = undetested; MA = not analyzed.

Material $>25 \mathrm{~m}$ is not able to be hendled by the laboratory. Material between 25 and $2 \mathrm{~mm}$ was crushed to $2 \mathrm{~nm}$ or less and then analyzed.

bonatituents detected in the laboratory, but not Identifled in rable 2-1. 
Table 7-5. Sleve Analyses for Soll Fractions Processed in Test "2 (Percent by Weight). (Serne et al 1993).

\begin{tabular}{|l|r|r|r|r|}
\hline \multicolumn{1}{|c|}{ Fraction (mm) } & $\begin{array}{c}150 \mathrm{to} \\
25 \mathrm{~mm}\end{array}$ & $\begin{array}{c}25 \mathrm{to} \\
2 \mathrm{~mm}\end{array}$ & $\begin{array}{c}2 \text { to } \\
0.425 \mathrm{~mm}\end{array}$ & $<0.425 \mathrm{~mm}$ \\
\hline$>50.8$ & 95.42 & 0.00 & 0.00 & 0.00 \\
50.8 to 25.4 & 4.26 & 0.00 & 0.00 & 0.00 \\
25.4 to 12.7 & 0.00 & 14.46 & 0.00 & 0.00 \\
12.7 to 9.5 & 0.00 & 18.78 & 0.00 & 0.00 \\
9.5 to 2 & 0.02 & 63.79 & 1.21 & 0.03 \\
2 to 1 & 0.01 & 2.92 & 27.32 & 1.28 \\
1 to 0.425 & 0.05 & 0.02 & 62.86 & 2.65 \\
0.425 to 0.212 & 0.03 & 0.01 & 5.86 & 51.78 \\
0.212 to 0.15 & 0.01 & 0.00 & 0.08 & 9.58 \\
0.15 to 0.075 & 0.02 & 0.02 & 0.09 & 11.07 \\
$<0.075$ & 0.17 & 0.01 & 2.58 & 23.61 \\
\hline
\end{tabular}

Bold indicates size fraction that should be in the plle.

\subsubsection{Analytical Rosults}

During processing and after processing was completed, soll and effluent samples were collected and sent offsite for analyses to assess which contaminants were in each of the process streams and to determine what water treatment, if any, would be required for effluent to meet purgewater acceptance standards. A summary of laboratory results is shown in Table 7-6. Additional data are included in Appendix B.2.

Offsite analyses (Table 7-6) show that all the constituents in all the soil streams were below the performance limits for the test, and the highest concentrations of urantum and chromtum were in the fine soli particles. The average activity of urantum in solls processed was $1.4 \mathrm{pCl} / \mathrm{g}$ in the 25- to 2-mm process pile, $12.1 \mathrm{pCl} / \mathrm{g}$ in the 2- to $0.425-\mathrm{mm} \mathrm{plle}$, and $93.6 \mathrm{pCi} / \mathrm{g}$ in soll particles $<0.425 \mathrm{~mm}$. This confirmed that the system tested effectively separated solls such that the concentration of uranium was significantly reduced in the more coarse soil fractions. A similar reduction in concentrations was seen for chromium.

Process effluent from Test 2 was filtered in the field using a $0.45-\mu \mathrm{m}$ filter. Analyses showed that only $178 \mu \mathrm{g} / \mathrm{L}$ of the uranium was found in the filtered effluent (Table 7-6). As noted by Serne et al. (1993), this may have been due to a short contact time as compared with Test "1 (where effluent was not filtered in the field), or to lower concentrations of uranium in the solls and 11ttle or no green material in the solls processed. Regardless of the reason, these data indicate that flocculation of particles and filtering may be sufficient to treat process effluent to meet purgewater acceptance standards such that it can be recycled in a soll treatment system. 
Table 7-6. Test \#2 Laboratory Analyses for Each of the Process Piles (Appendix B.2).

\begin{tabular}{|c|c|c|c|c|}
\hline Sample & $\begin{array}{c}25 \text { to } 2 \mathrm{~mm} \\
\text { (avg) }\end{array}$ & $\begin{array}{c}2 \text { to } 0.425 \mathrm{~mm} \\
(\mathrm{avg})\end{array}$ & $\begin{array}{c}<0.425 \mathrm{~mm} \\
(\text { avg) }\end{array}$ & $\begin{array}{c}\text { F } 1 \text { tered } \\
\text { Water (avg) }\end{array}$ \\
\hline Contaminant & $(p C i / g)$ & $(p C i / g)$ & $(p C i / g)$ & $(p C i / L)$ \\
\hline $\begin{array}{l}\text { Cobalt-60 } \\
\text { Ces Ium-137 } \\
\text { Lead-212 } \\
\text { Lead-214 } \\
\text { Rad Ium-224 } \\
\text { Radium-226 } \\
\text { Ruthentum-106 } \\
\text { Ant imony-125 }\end{array}$ & $\begin{array}{l}0.106 \\
0.118 \\
0.568 \\
0.506 \\
0.572 \\
0.491 \\
U \\
U\end{array}$ & $\begin{array}{l}0.260 \\
0.256 \\
0.671 \\
0.438 \\
0.675 \\
0.417 \\
U \\
U\end{array}$ & $\begin{array}{l}0.242 \\
0.273 \\
1.049 \\
0.681 \\
1.051 \\
0.632 \\
U \\
U\end{array}$ & $\begin{array}{c}U \\
U \\
- \\
- \\
- \\
\bar{U} \\
4.2\end{array}$ \\
\hline Uranium (total) & 1.432 & 12.05 & 93.63 & $\begin{array}{l}(\mu \mathrm{g} / \mathrm{L}) \\
177.8\end{array}$ \\
\hline & $(\mathrm{mg} / \mathrm{kg})$ & $(\mathrm{mg} / \mathrm{kg})$ & $(\mathrm{mg} / \mathrm{kg})$ & $(\mathrm{mg} / \mathrm{L})$ \\
\hline $\begin{array}{l}\text { Silver } \\
\text { Aluminum } \\
\text { Barium } \\
\text { Beryllium } \\
\text { Calcium } \\
\text { Cadmium } \\
\text { Cobalt } \\
\text { Chromium } \\
\text { Copper } \\
\text { Iron } \\
\text { Mercury } \\
\text { Potassium } \\
\text { Magnesium } \\
\text { Manganese } \\
\text { Sodium } \\
\text { Nickel } \\
\text { Lead } \\
\text { Antimony } \\
\text { Tin } \\
\text { Vanadium } \\
\text { Zinc }\end{array}$ & $\begin{array}{c}0.91 \\
4,292 \\
70.0 \\
0.22 \\
5,450 \\
0.00 \\
9.08 \\
4.18 \\
158 \\
24,583 \\
0.00 \\
309 \\
3,492 \\
267 \\
32.8 \\
9.19 \\
1.93 \\
1.70 \\
0.00 \\
63.9 \\
51.3\end{array}$ & $\begin{array}{c}4.00 \\
7,567 \\
93.1 \\
0.35 \\
7,083 \\
0.00 \\
11.8 \\
18.8 \\
644 \\
33,750 \\
0.22 \\
569 \\
5,533 \\
406 \\
478 \\
31.3 \\
4.93 \\
2.25 \\
0.00 \\
98.5 \\
106\end{array}$ & $\begin{array}{c}4.73 \\
7,867 \\
220 \\
0.04 \\
5,067 \\
0.00 \\
7.80 \\
41.3 \\
580 \\
24,333 \\
0.25 \\
683 \\
4,167 \\
287 \\
367 \\
38.3 \\
13.0 \\
0.00 \\
6.83 \\
70.7 \\
75.7\end{array}$ & $\begin{array}{l}0.0014 \\
0.06 \\
0.04 \\
0.0004 \\
23.7 \\
0.00 \\
0.00 \\
0.0022 \\
0.029 \\
0.064 \\
0.00 \\
2.13 \\
4.77 \\
0.0134 \\
7.83 \\
0.00 \\
0.0006 \\
0.00 \\
0.00 \\
0.00 \\
0.0022\end{array}$ \\
\hline
\end{tabular}

U. undetected.

Bold indicates constituent was detected in only one sample.

Analysis for VOCs was performed on the fresh water stream and the process water stream in Test \#1 and Test \#2. VOCs for Test \#2 were undetected except for laboratory additions including 1,1,1-trichloroethane, methyl ethyl ketone, and tetrahydrofuran.

Aroclor-1248 was the only PCB detected. It was detected below test performance levels $(2,200 \mathrm{ppb})$ in all soll samples that were taken. The highest concentrations were found in three slurry soll samples with the highest 
being $970 \mathrm{ppb}$. It was found in five of eight process effluent samples. Using zero for the nondetects, the average concentration found in the effluent was $0.35 \mathrm{ppb}$ with a high of $1.3 \mathrm{ppb}$. In comparison, the purgewater acceptance standard for mixed PCBs is $1 \mathrm{ppb}$.

Soll particles of the same size fraction were composited from each of the process streams $(\theta .9$. , the 2- to $0.425-\mathrm{mm}$ fraction of materials in each process streams). The composited solls were analyzed in onsite laboratortes for metals and radionuclides. As was the case with offsite analyses of process streams (Table 7-6), the results (Table 7-7) show that the highest concentrations of uranium and chromium were in the fine soil particles. In the sleved solls (Table 7-7), the concentration of uranium-238 in soll particles $<0.425-\mathrm{mm}$ was $26.9 \mathrm{pCi} / \mathrm{g}$ compared to $6.8 \mathrm{pCi} / \mathrm{g}$ in the 2 - to $0.425-\mathrm{mm}$ size fraction. The concentration of uranium-238 in particles $<0.075 \mathrm{~mm}$ was 54 $\mathrm{pCi} / \mathrm{g}$ compared to $35 \mathrm{pCi} / \mathrm{g}$ for particles between 0.15 and $0.075 \mathrm{~mm}$ and 23.3 $\mathrm{pC} 1 / \mathrm{g}$ for particles between 0.212 and $0.15 \mathrm{~mm}$.

The distribution of uranium-238, uranium-235, and cobalt-60 in each of the sieved size fractions is shown in Figures 7-3a, 7-4a, and 7-5a, respectively. Estimated concentrations of uranium-238, uranium-235, and cobalt-60 in each process pile are shown in Figures 7-3b, 7-4b, and 7-5b. Values shown were calculated considering the measured radioactivity levels in each fraction of solls (Table 7-7) and the distribution of solls for each process pile (Table 7-5). As in Test $\# 1$, uranium-238 was the primary contaminant.

A weighted average of the size distribution of solls in each process stream (Figure 7-2b) with uranium-238 analytical data (Figure 7-3b) shows that by separating soil in the field at a cutpoint of $0.425-\mathrm{mm}$ uranium-238 concentrations were reduced by a factor of 45 and the fraction of solls was reduced by $98 \%$ (by weight).

\subsection{SEPTENBER 9 TESTIMA}

In addition to tests on September 8, 1993, solls containing green material were processed on September 9, 1993 to see if slight equipment modifications recommended (Section 6.0) would result in a better, more successful treatment process. Changes were made to the trommel angle and speed to increase retention time and energy input. Sprays were added to the $0.425-\mathrm{mm}$ screen, and speed of the screen vibration was reduced to enhance particle separation. Other equipment parameters are specified in Table 7-2. This test was made using green material from one of the piles on the west side of the trench. The trommel speed was increased to $7 \mathrm{rpm}$ to provide more energy to separate solls. The radioactivity of the field solls was measured at 6,000 to $13,000 \mathrm{dpm}$ with an average of 9,000 dpm. Approximately 5 tons of sol1 were processed. After processing, no green particles $>3 \mathrm{~mm}$ in diameter were detected in the trommel oversize material. This could be for one of two reasons: (1) feed material did not contain larger particles of the green material, which seems unlikely; or (2) the increased trommel speed provided enough additional energy to break down the larger green particles more than in Test \#1. Increasing the speed of the trommel to 9 or $10 \mathrm{rpm}$ would likely provide the required energy to remove green particles from the trommel oversize stream $(>2 \mathrm{~mm})$. 
Table 7-7. Test \#2 Size Distribution of Contaminants in Processed Soils After Wet-Sieving. (Serne et al. 1993)

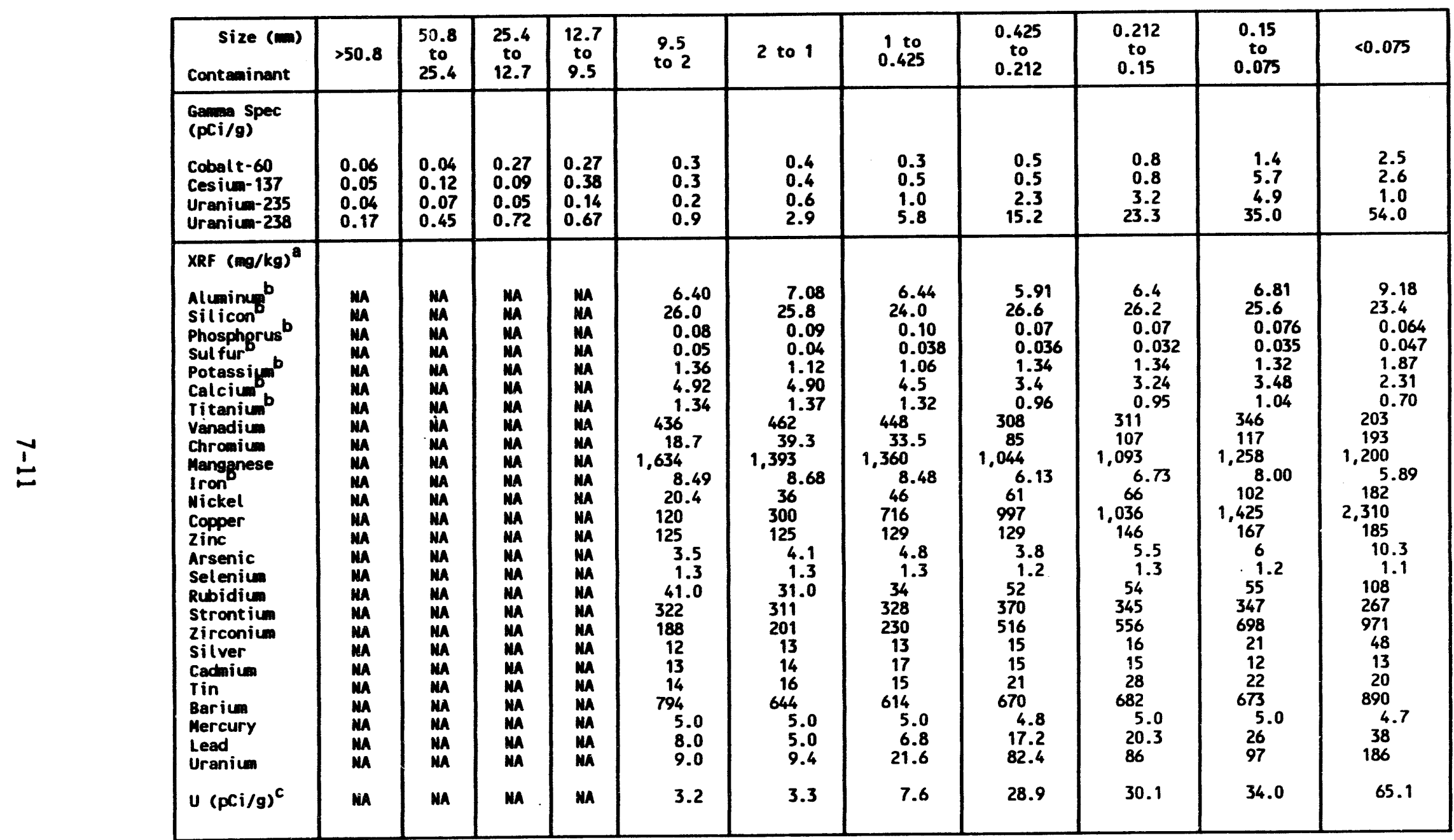

$M A=$ Hot analyzed.

Metals are averages for one run only; data for the second run was similar and is included in the PNL report (Serne et al. 1993).

$b_{1 \%}$ is equivalent to $10,000 \mathrm{mg} / \mathrm{kg}$.

conversion factor for total uranium $(\mathrm{mg} / \mathrm{kg})$ times $0.35=\mathrm{pci} / \mathrm{g}$ for ${ }^{235} \mathrm{u}$ and $238 \mathrm{u}$ only. 
DOE/RL-93-96, Rev. 0

Figure 7-3a. Test \#2, Wet-Sieved Size Distribution of Processed Soils, Uranium-238 Gamma Spectrometry. (Serne et a1. 1993)

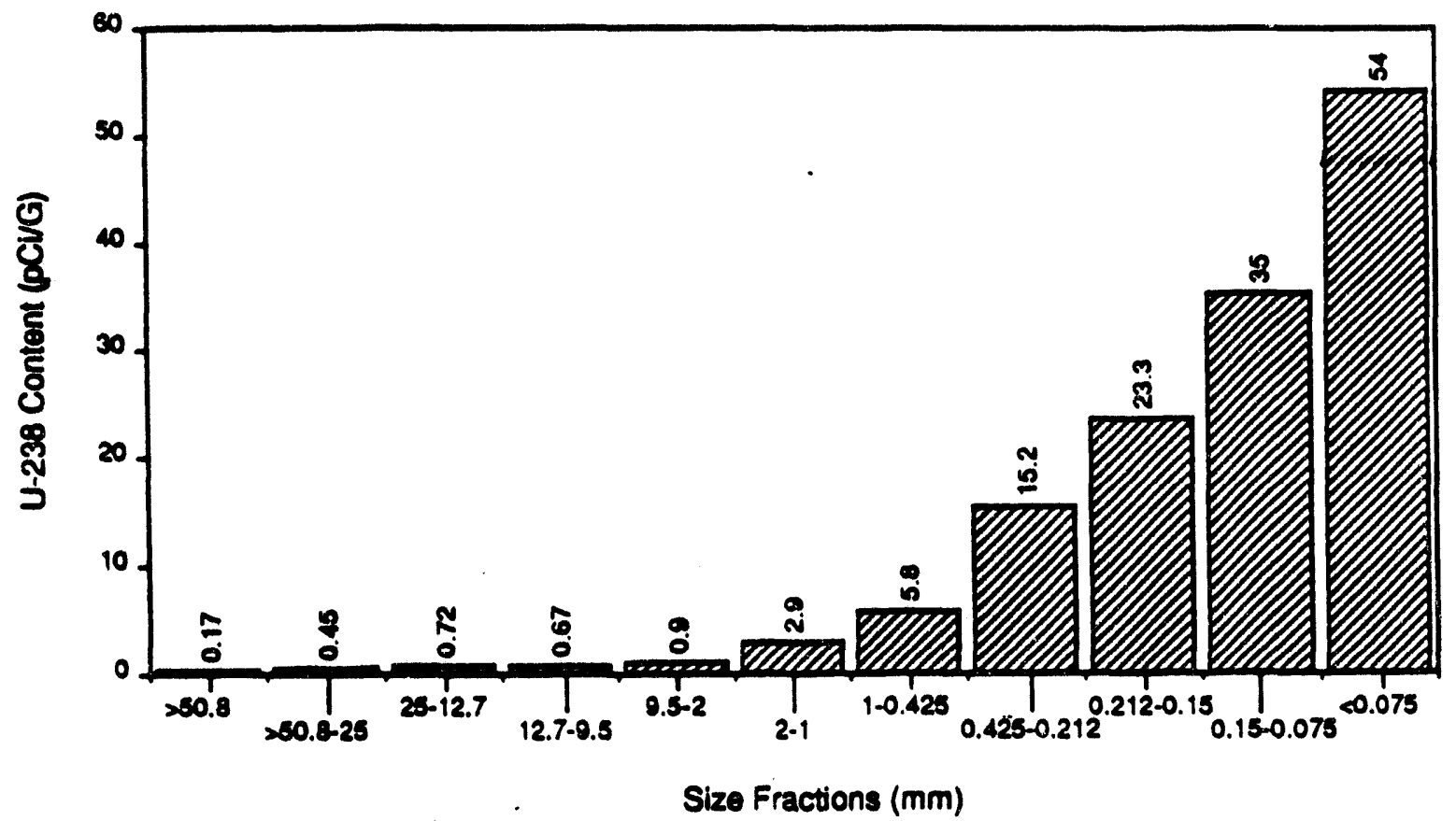

Figure 7-3b. Test \#2, Contaminant Concentrations in Each Process. Pile, Uranium-238 Gamma Spectrometry.

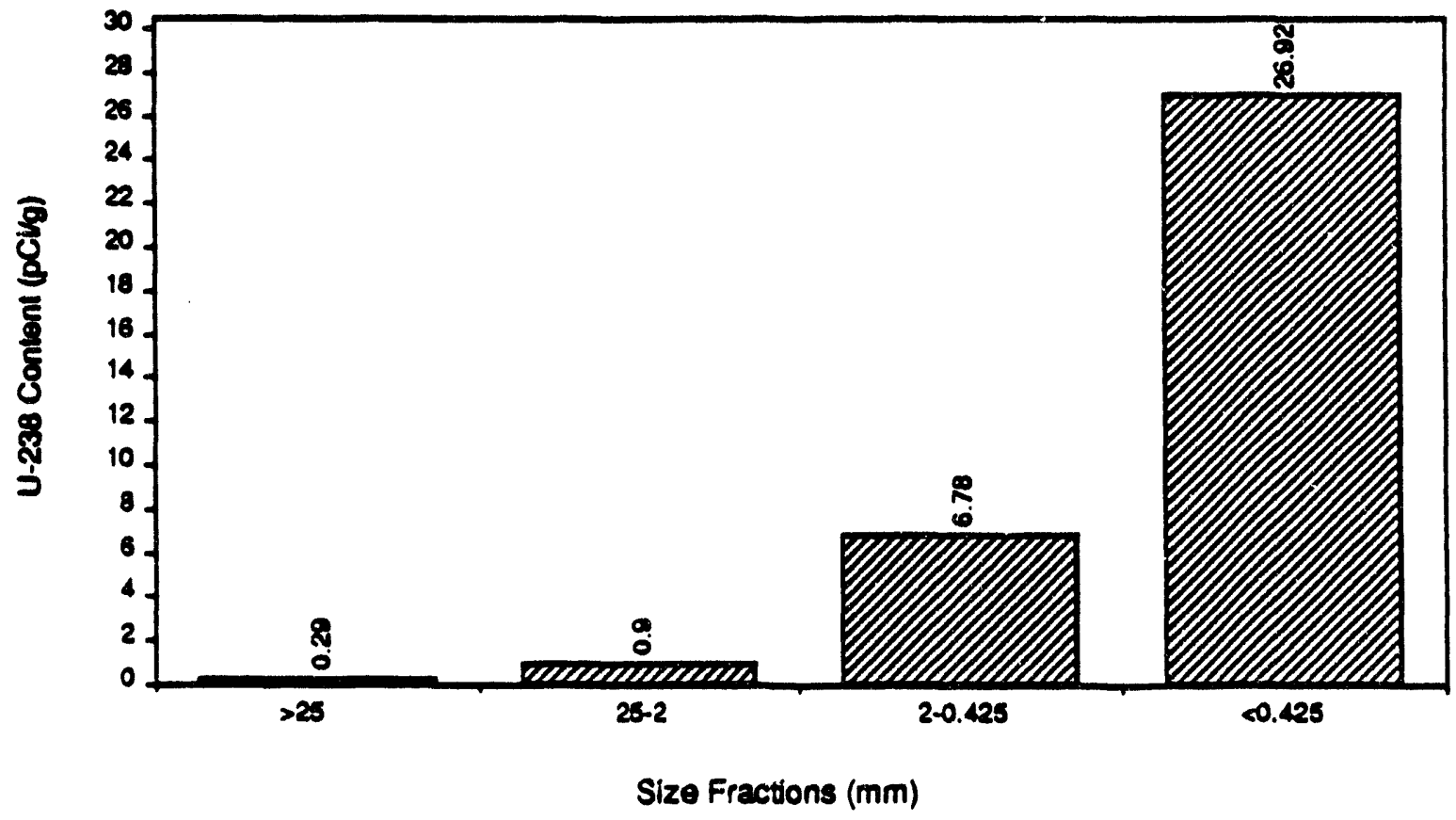

GEMMB.9 
Figure 7-4a. Test \#2, Wet-Sieved Size Distribution of Processed Soils, Uranium-235 Gamma Spectrometry. (Serne et al. 1993).

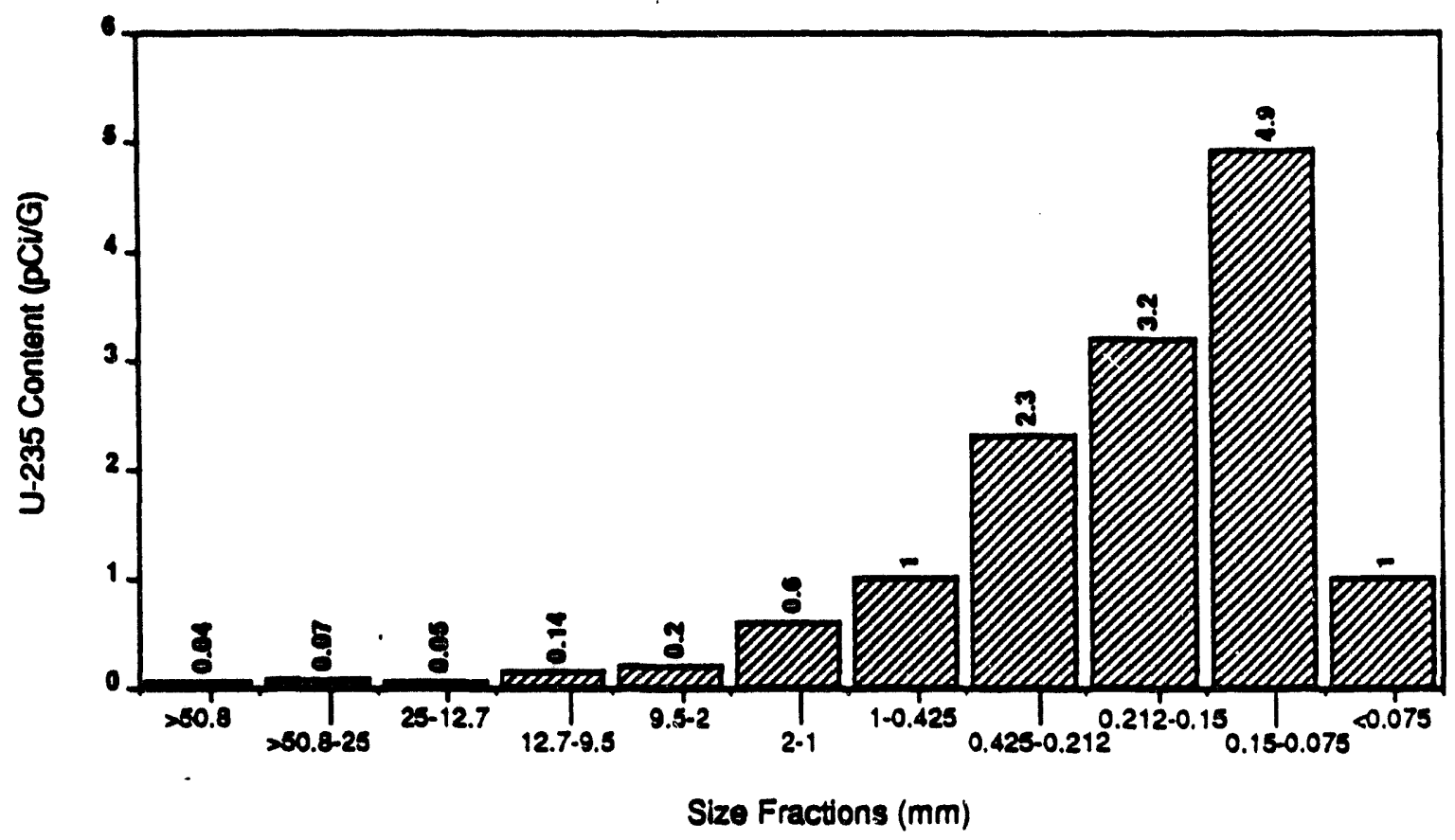

Figure 7-4b. Test \#2, Contaminant Concentrations in Each Process Pile, Uranium-235 Gamma Spectrometry.

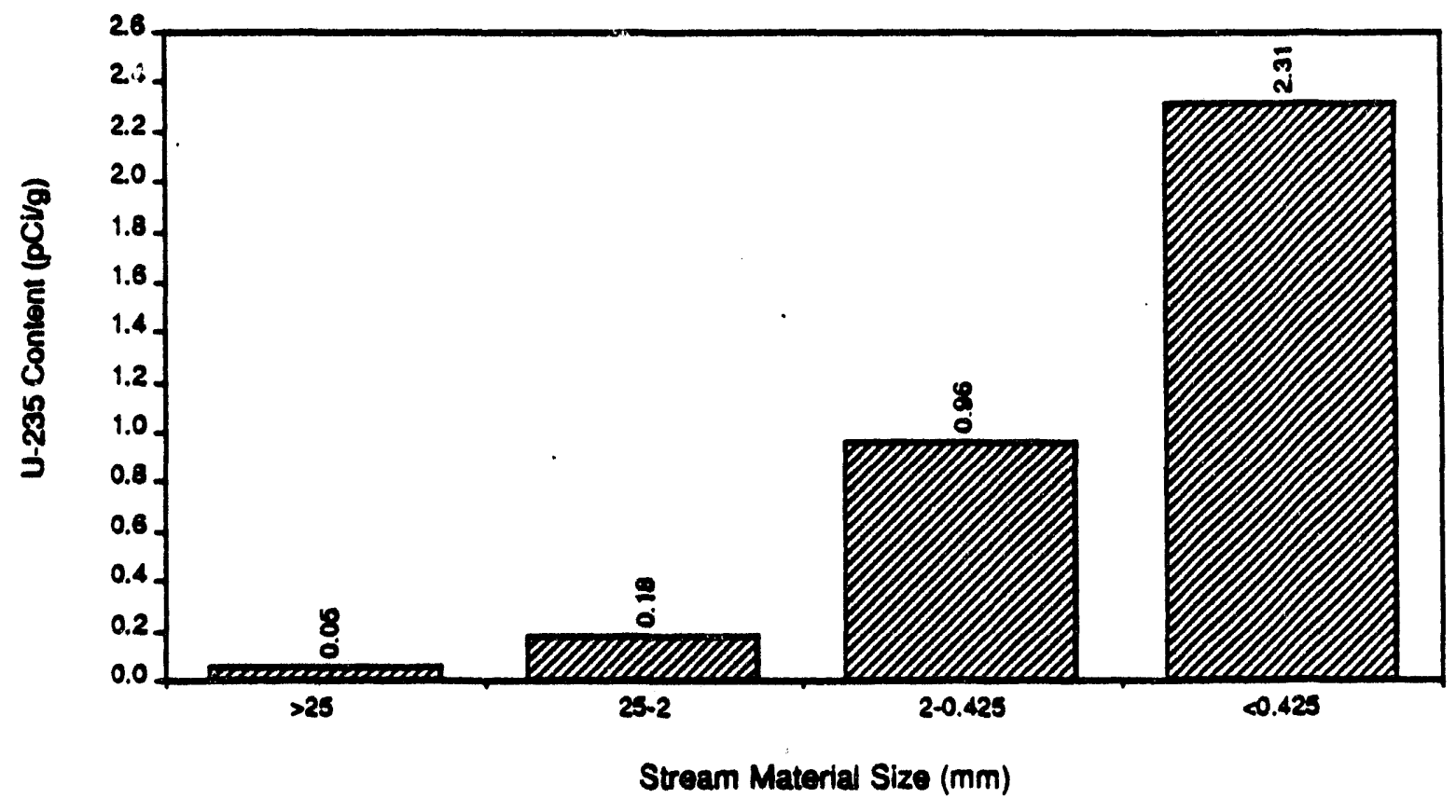

GEMMO. 10 
Figure 7-5a. Test \#2, Wet-Sieved Size Distribution of Processed Soils, Cobalt-60 Gamma Spectrometry. (Serne et a1. 1993)

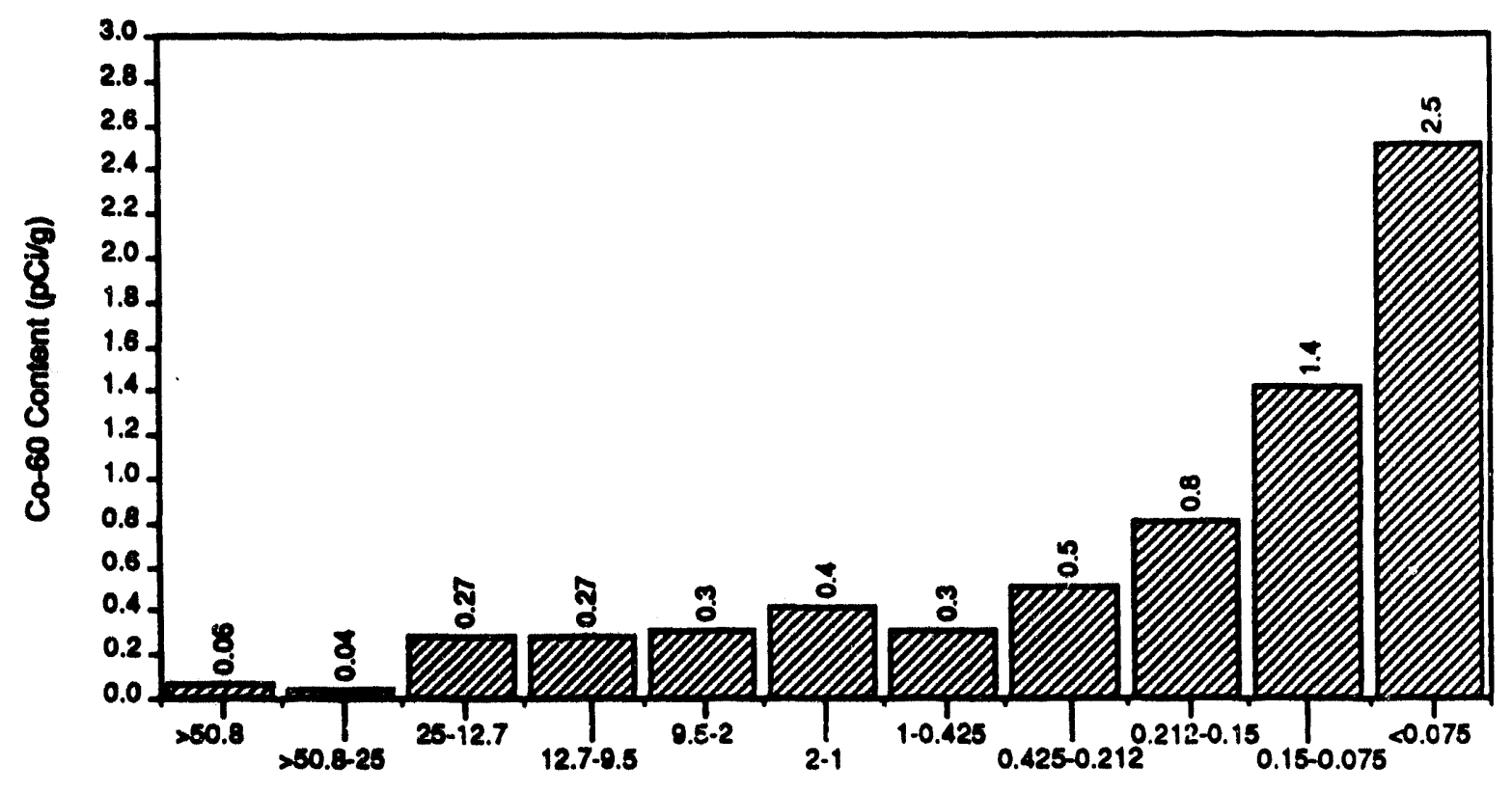

Size Fractions ( $\mathrm{mm}$ )

Figure 7-5b. Test \#2, Contaminant Concentrations in Each Process Pile, Cobalt-60 Gamma Spectrometry.

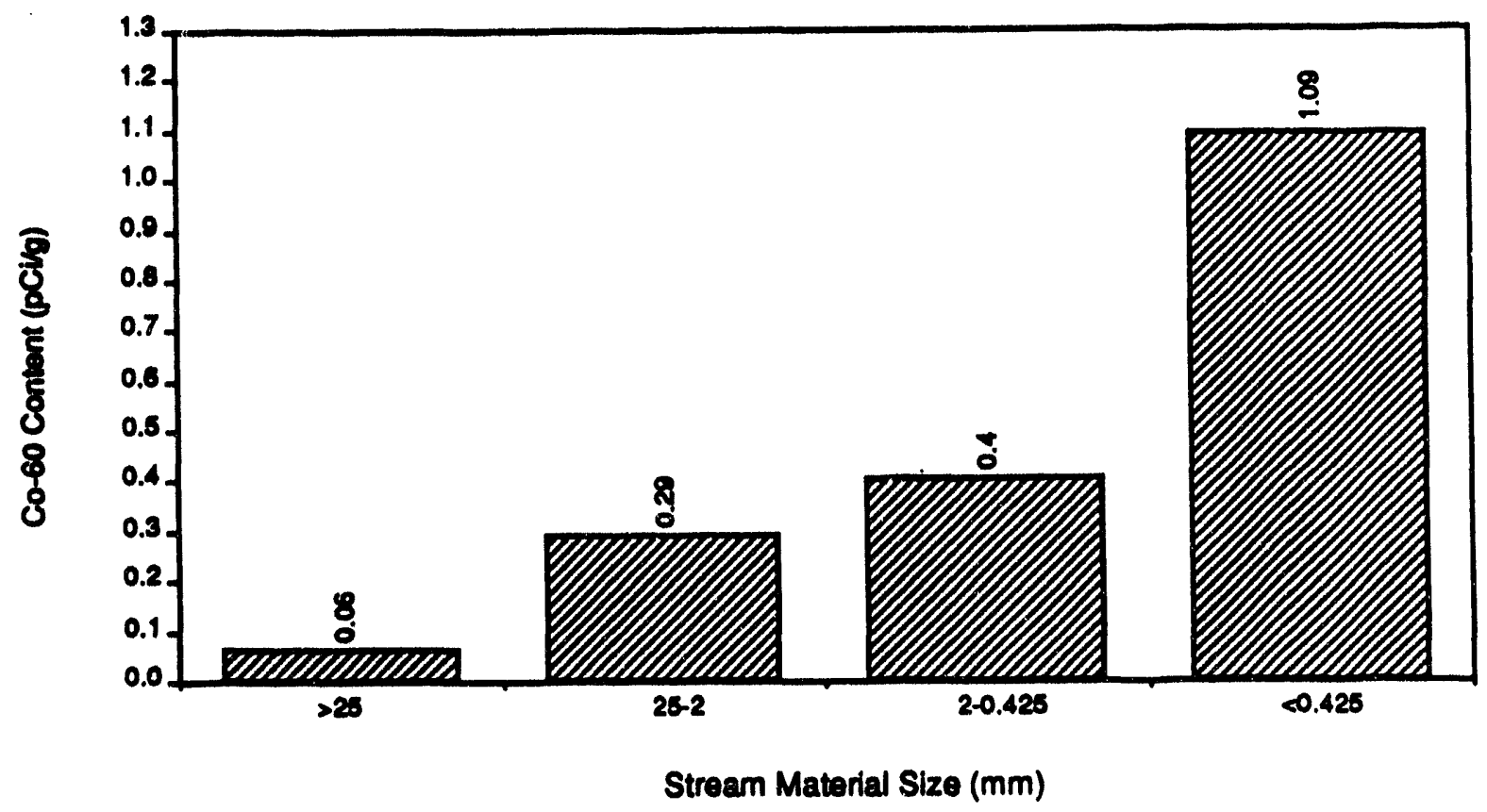

GENM1 12503-L 
The 2- to $0.425-\mathrm{mm}$ material was unchanged. It still visibly contained particles of the green material, and activity levels of approximately $400 \mathrm{cpm}$ were measured in the field. The $0.425-\mathrm{mm}$ screen was sprayed with water using the spray bar off the primary screen in a further attempt to break down the green particles. The added sprays washed the soils more effectively as they traveled across the screen, but didn't seem to reduce or break down the green material. It was, therefore, determined that an attrition scrubber is likely required. Results from Test \#1 showed that an attrition scrubber would break down the green material so that the fraction of fine particles $(<0.75 \mathrm{~mm})$ increased and the remaining larger material exhibited significantly lower activity.

Only field measurements were made; no samples were taken to send to the laboratory because radioactivity was found in soil fractions intended to be clean, and sufficient samples of soils with the green material were taken in Test \#1. 
DOE/RL-93-96, Rev. 0

\subsection{WATER TREATMENT}

\subsection{APPROACH}

Preoperational testing of the water treatment unit was performed during the month of September to ensure that all equipment was operating appropriately. Minor modifications/repairs were made based on this test. During the week of September 20, 1993, the clarification portion of the system was transported to the north process pond and prepared to treat the process effluent in the fractionation tanks from Test \#1 and Test \#2.

Water treatment tests began the first week of November. The tests were conducted using a skid-mounted clarifier obtained from the EPA and renovated for the test. Renovations included replacing pumps, adding pressure gages and water flow gages, and plumbing.

In spite of previous laboratory indications to the contrary, in Test \#1 uranium activity (1ikely due.to the green material) was measured in the process effluent (Tables 6-8 and 6-10). Therefore, based on laboratory stir tests, a commercial flocculant was selected to enhance particle settling rates, and ferric chloride was added to precipitate uranium from the effluent. Effluent was to be treated to remove suspended solids and reduce the concentration of constituents in the effluent to purgewater acceptance levels (Appendix A). In addition to the clarifier, a skid-mounted ion exchange unit was made available, if needed. A schematic of the clarifier and ion exchange system is shown in Figure 8-1.

During the physical separations test, process effluent was redistributed between three fractionation tanks. Most of the effluent was initially pumped into tank $\# 1$; therefore, the greatest fraction of sediment is in this tank. When more volume was needed in tank \#1, effluent was pumped to tanks \#2 and \#3. Process effluent was redistributed between the three tanks as needed. Although about 151,000 L of effluent from Test \#1 (Figure 6-1) and Test \#2 (Figure 7-1) were put in the fractionation tanks, when the water treatment test started, there was approximately 121,000 L of effluent distributed between the three tanks. The difference was due to evaporation during the period between Test \#1 and Test \#2.

In a full-scale system, process effluent would be treated in-line and recycied. This would reduce the volume of water used in the system. Final treatment or disposal of process water would not generally occur until soil processing is completed.

Samples shown in Table 8-1 were collected before (influent) and after treatment (effluent). One set of samples was collected about midmorning and another at midafternoon. Samples were only collected for offsite analyses on those days when the field supervisor determined that the system was operating adequately.

Samples were sent to offsite laboratories for EPA Level III chemical analyses and Level $V$ radiochemical analyses (EPA 1990). Samples sent to onsite laboratories received EPA level II analyses using inductively coupled plasma/mass spectrometry (ICP/MS). 
DOE/RL-93-96, Rev. 0

Figure 8-1. Schematic of the Water Treatment System.

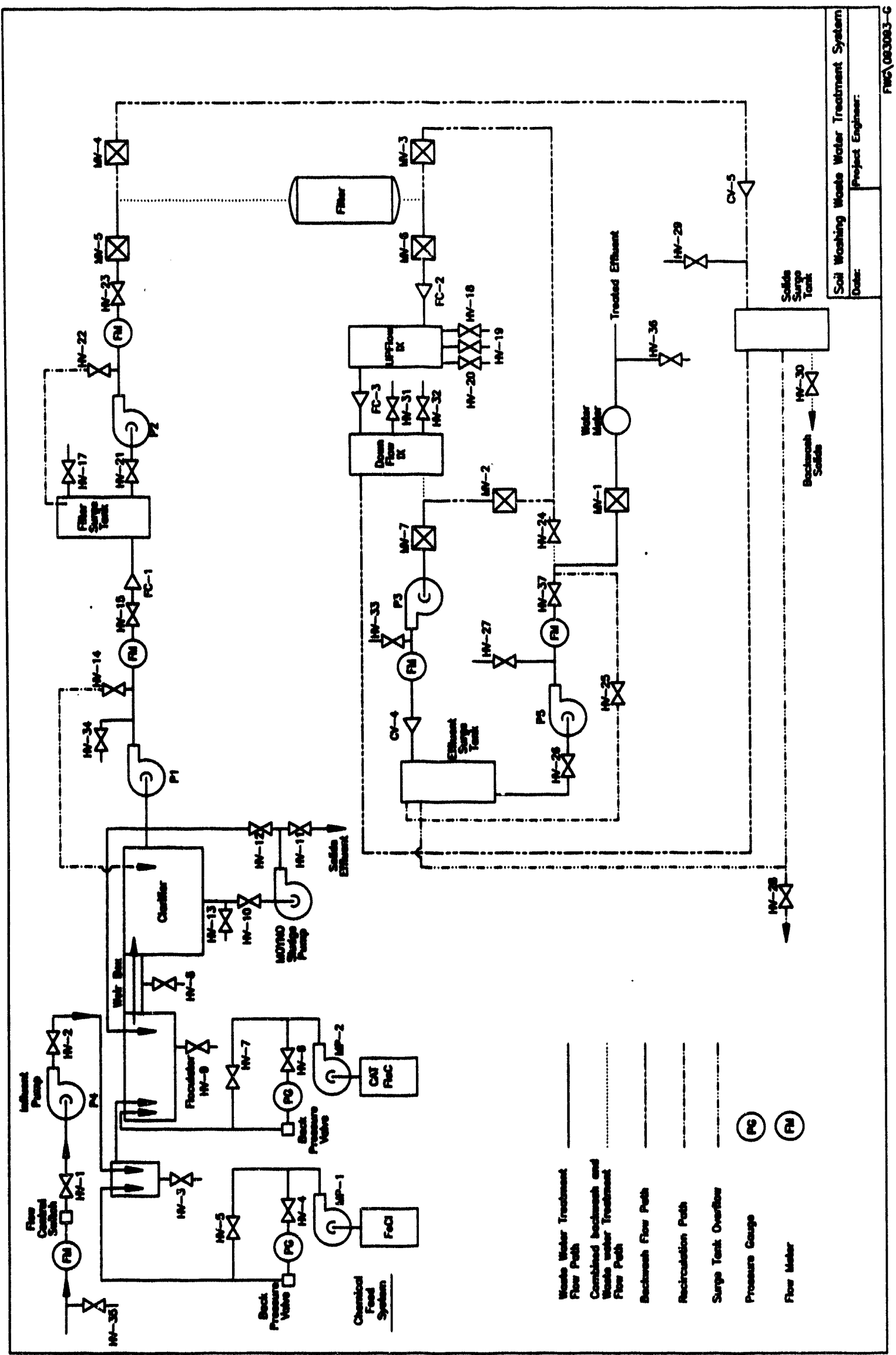




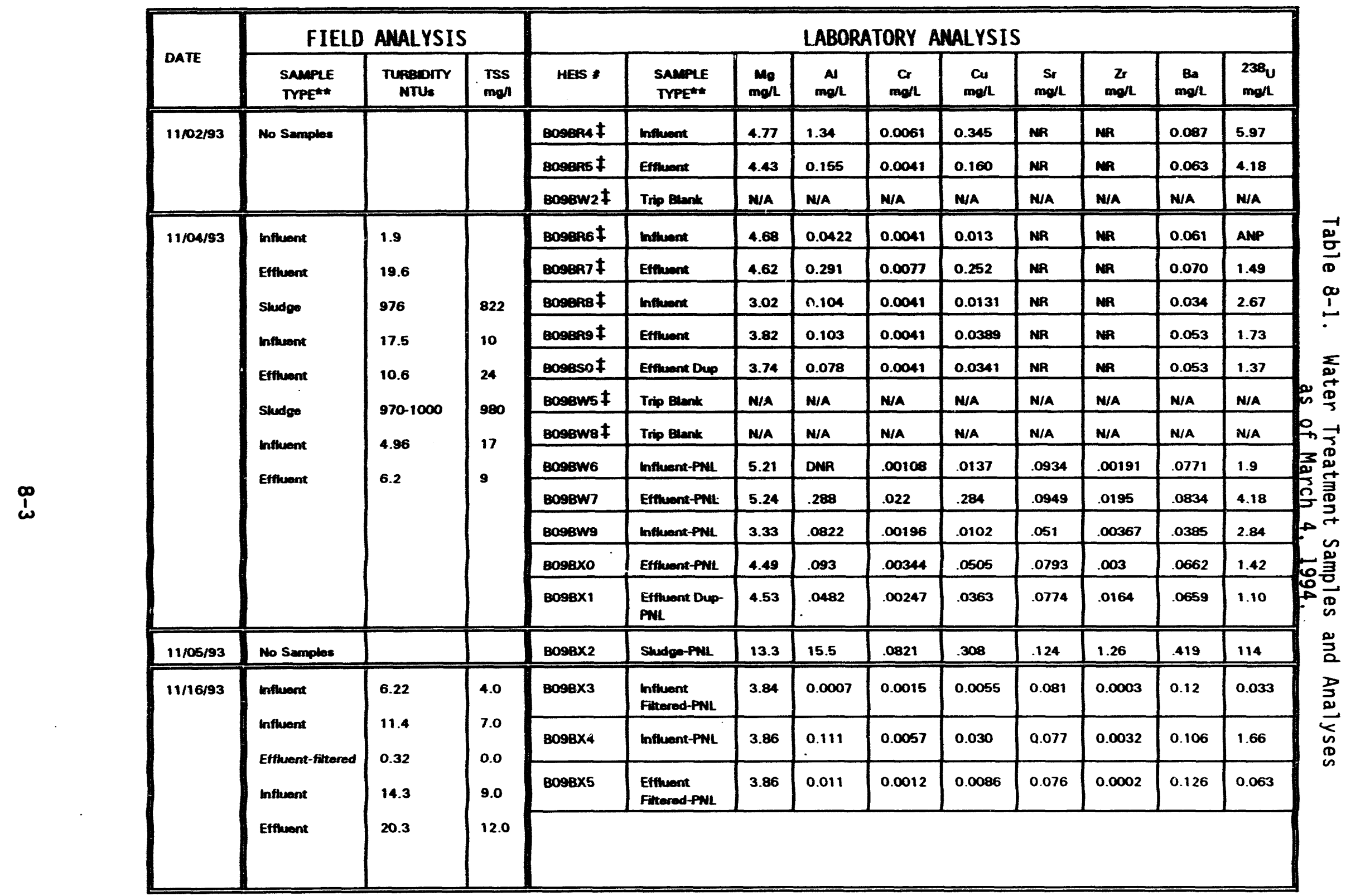

** Referring to Figure 1-3: Influent is Stream $\$ 9$

F Additional data provided in Appendix $B .3$
M/A Analysis is Mot Applicable for Trip Blanks

AMP Analysis Mot Possible

DMHR Did Not Receive 
A sample screening trailer was set up in the field to obtain quick analyses to assess system performance. Chromium concentrations were measured in the screening trailer using a Hach kit (a tradename of Hach Company). Turbidity measurements were al so made to determine suspended solids concentrations.

\subsection{RESULTS}

Water treatment operations started on November 2, 1993. The first day of operation consisted primarily of filling the clarification system and establishing constant flow conditions. Process effluent from tank \#2 was pumped into the treatment system (about $30,300 \mathrm{~L}$ ). After treatment, effluent was returned to tank \#2. Initial testing began by processing the wastewater at $132 \mathrm{~L} / \mathrm{min}$. At this flow rate, ferric chloride was added to the wastewater at a rate of $35 \mathrm{mg} / \mathrm{L}$ of water. This was added to the waste stream in the flash mix tank. Next, a cationic polymer was added to the stream leaving the mix tank at a rate of $2 \mathrm{mg} / \mathrm{L}$ of water. Judging from the turbidity of the effluent and visual observatian inside the tank, few solids remained in tank \#2 after one treatment cycle. The water treatment flow rates were $189 \mathrm{~L} / \mathrm{min}$ when filling the clarifier, and $151 \mathrm{~L} / \mathrm{min}$ during steady-state processing.

The water treatment system did not operate on November 3, 1993 because repairs were required on the flocculator mixer, which had not worked well the first day of the test. Water treatment operations restarted on November 4. During the morning, process effluent was fed from t lik $\# 2$. By about 1:00 p.m., tank \#2 was empty, so water was fed from tank \#1. That afternoon, the ferric chloride feed pump was found to be out of orcier, so operators began adding ferric chloride by bucket. Water treatment was stopped on November 5 because the concentrated ferric chloride solution attached to the stainless steel pump seal and ruined the ferric chloride feed pump.

Field measurements from the first 2 days of sampling indicated that the flocculation process was working. However, problems with the ferric chloride feed pump prevented optimization of the flocculation process. In addition, it was determined that an in-line filter was needed after the clarifier to remove suspended solids. These problems resulted in 2 wh of downtime.

Water treatment operations restarted November 16 . A $10-\mu$ filter was installed after the clarifier. Ferric chloride was added by a Masterflex peristaltic pump, which did not have any corrosion problems and worked much better for this application. The pump delivered ferric chloride solution to the system at a rate of $10.5 \mathrm{~L} / \mathrm{hr}$. Most of the day, pumping pressure was used to open flow charnels in the frozen pipes and treatment system. Water was pumped from tank $\# 1$ to the treatment system and treated water was returned to tank \#1. Only $3 \mathrm{hr}$ of steady-state flow were achieved. Ferric chloride and polymer were added, but suspended particles did not flocculate.

Over the 3 days when treatment occurred, approximately half of the effluent in the fractionation tanks was processed in a single cycle through the clarifier skid. 
Several bench-scale tests were performed during the operation of the system in an attempt to optimize the process chemistry. The results of these tests indicated that controlling the amount of ferric chloride is crucial. If more than twice the concentration is added, no settling will occur. The volume of cationic polymer added is not as cructal, however. Large overdoses of polymer only slow the rate of flocculent formation and settling.

At this time, the outside temperature was dropping below $0^{\circ} \mathrm{C}$ during the nighttime hours. Several attempts were made to continue operations, but the effectiveness of the ferric chloride diminishes significantly at these lower temperatures. It was determined by field operators and engineers that modifications were required for the ferric chloride and flocculents to work effectively in the cold weather. As a result of processing problems caused by the freezing temperatures and to protect the environment from potential leaks caused by freezing of the system, operations were terminated just before Thanksgiving. Effluent was pumped from the water treatment system into the fractionation tanks, and the fractionation tanks were winterized by wrapping the valves with electrical heat tape. Tests are not expected to resume until spring at the earliest.

Analytical results of the tests completed in November 1993 (Table 8-1 and Appendix B.3) Indicate that the bulk of urantum was removed from the effluent during the treatment process. Validation reports for the offsite water treatment analyses are in progress and will be included in future revisions of this document.

Based on the tests and analyses on November 16, 1993, optimization of the flocculation process is expected to be successful in treating the effluent in the fractionation tanks when tests resume. Results of future treatment will be reported in future revisions of this document. 


\subsection{RESIOUALS MANAGEMENT}

Treatability tests were conducted in a surface contamination area. Therefore, after processing was completed, in accordance with the test plan, solls in each of the process plles were flattened and blended into the surrounding landscape to be remediated in accordance with the record of deciston (ROD) for the 300-FF-1 Operable Unit.

Fine solls $(<0.425 \mathrm{~mm})$ in the process slurry were gravity-fed to the fractionation tanks. Approximately 32,000 gal of process effluent and assoclated fines from Test $\# 1$ and Test $\# 2$ were in the three 75,000-L fractionation tanks at the time water treatment tests started.

The intent of water treatment tests was to cycle effluent through the treatment system back to the fractionation tanks unt 11 enough solids were removed from the fractionation tanks and effluent was treated to meet purgewater acceptance standards (Appendix A). However, because water treatment tests were interrupted due to cold weather, only one cycle was completed for about half of the water. When water treatment tests resume, it is anticipated that cycling of the effluent from the tanks through the water treatment system will continue.

Solids separated from the effluent in the water treatment process were pumped to a B-25, LSA box located near the fractionation tanks. To date, approximately $2 \mathrm{yd}^{3}$ of fine solls have been removed from the tanks and placed in the B-25 LSA box. Additional boxes are available for when tests resume. The LSA boxes are expected to remain in the bottom of the north process pond according to the waste control plan until final remediation begins, when they will be disposed of with the other 300-FF-1 Operable Unit wastes in accordance with an ROD when it is completed.

Treated effluent was contained in the fractionation tanks. Disposition of the effluent at the conclusion of water treatment tests will be in accordance with the waste control plan. At this time, it is expected that the effluent will be evaporated. The Washington Department of Health was notified of this intent. 


\subsection{DATA MANAGEMENT}

All data collected during this study wäs managed in accordance with WHC environmental investigation instructions (EII) (WHC 1988) and the 300-FF-1 Data Management Plan (DOE-RL 1990, Attachment 4).

Samples were assigned a HEIS computer code number, and information associated with the samples will be entered into the HEIS database. Copies of data obtained were forwarded to the Environmental Data Management Center to be placed in the administrattve record and/or project records, as applicable.

A fleld logbook was maintained recording test times, personnel participating, pre-job safety and tallgate meetings, and occurrences during tests. The logbook, currently in use to record water treatment field activities, will be issued and entered into the administrative record on completion.

Samples were managed in accordance with WHC chain-of-custody procedures (WHC 1988, EII 5.1). 


\subsection{QUALITY ASSURANCE/QUALITY CONTROL}

Analytical samples and other investigation activities were subject to in-process quality control (QC) measures and performed in accordance with manuals and procedures specified in the Remedial Investigation/Feasibility Study Work Plan for the 300-FF-1 Operable Unit (DOE-RL 1990) in both the field and laboratory. QA samples for tests included duplicates and trip blanks shown in Tables 4-1 and 4-2 and in Appendix B.

Analytical methods, analytical levels, detection 1 imits, precision and accuracy requirements for data receiving Level III and Level $V$ analysis at an offsite laboratory and presented in Appendix $B$ are specified in Table 11-1.

All of the samples receiving Level III chemical analysis and Level $V$ radiochemical analysis were validated using WHC Level B RCRA data validation procedures as required in Section 5.0 of the test plan (DOE-RL 1993b). The two data validation reports, one for Test $\# 1$ and one for Test $\# 2$, are included as part of AppendiX B.1 and B.2 of this report.

\subsection{DATA QUALIFIERS ANO FLAGS}

Certain qualifiers and flags have been added to the data by the laboratory or as the result of the data validation. The following qualifiers and flags accompany data in this report.

\section{- Qualifiers addad by the laboratory}

$U$ Indicates that this constituent was analyzed for but undetected.

$L$ Indicates that the value is less than the contract required detection limit (CROL) and above the maximum detection limit (MDL).

B Laboratory blanks exceeded acceptable criteria.

$X Y Z$ Indicates that matrix interference was encountered causing higher detection limits and false results in the gamma scan analysis.

- Elags added as a result of data validation

Q Data can be used qualitatively, but regulatory decisions should not be made on a single flagged data point.

$H \quad$ Indicates holding time missed. Data can be used qualitatively, but regulatory decisions should not be made on a single fiagged data point. 
Table 11-1. Analytical Methods, Detection Limits, Precision and Accuracy.

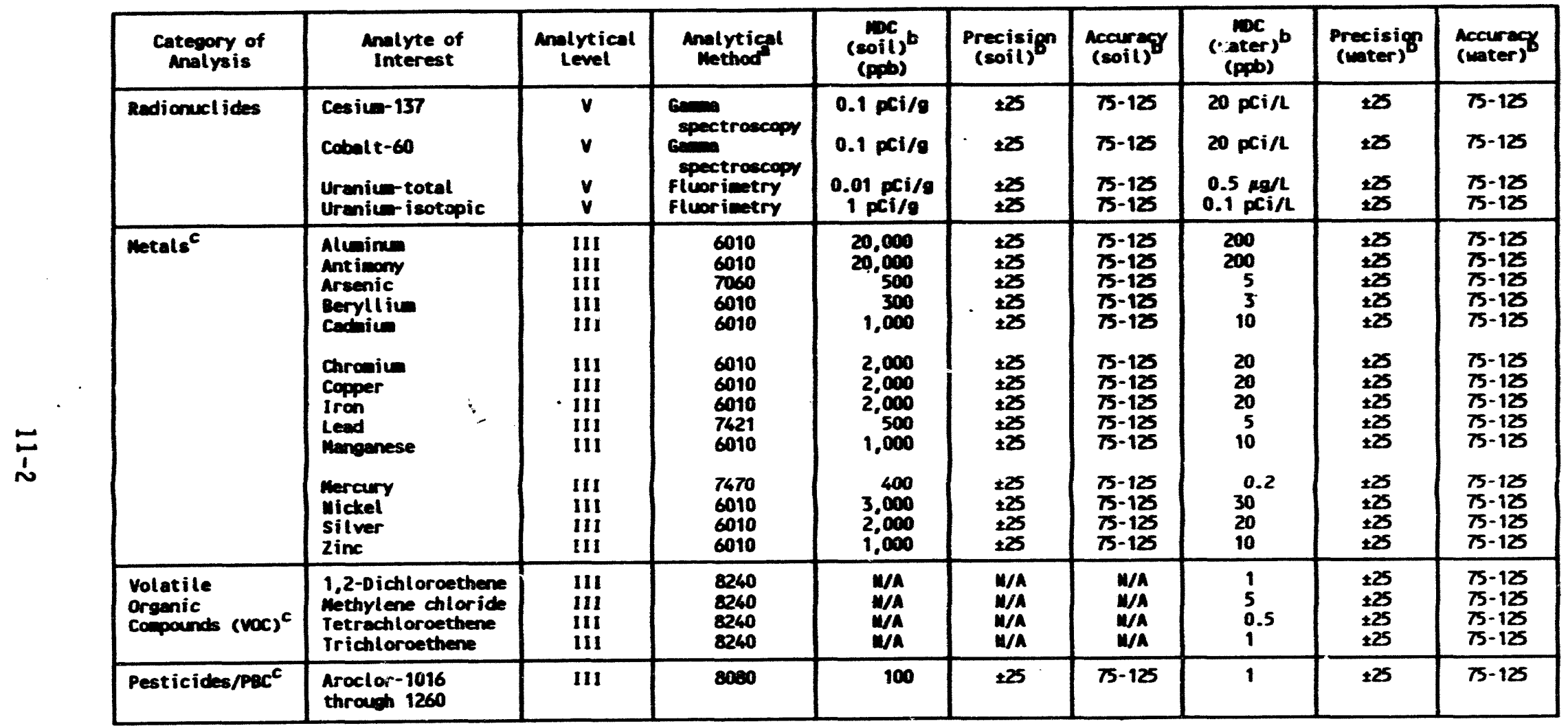

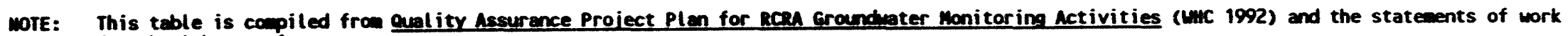
for the laboratories.

all analytical methods shall be unc-approved methods.

boc refers to ninimen detection concentration. Precision is expressed as relative percent difference (RPD) and accuracy is espressed as percent recovery (XR).

Gethods specified are from Iest Methods for Evaluatine Sol id uaste (EPA 1990). 
The $X Y Z$ qualifier attached by the laboratory was the result of matrix interference being encountered. This resulted in the laboratory being unable to meet the CRDL and also caused the total error for the analys is to increase. This increase in the error and the low level of the measurements raises the question as to whether or not the analytes were actualiy detected.

Q flags were given to data for two reasons. These reasons are discussed in the data validation report and include: the relative percent difference between matrix duplicates exceeds $25 \%$ and blanks exceeding two times the MDL (this results in a $Q$ flag on all samples of that matrix taken the same day as the blank).

There were no data received from the laboratory with a $B$ qualifier. No data were rejected during the data validation process. Details of what data were flagged and why are given in the data validation reports in Appendix B. 2 . Flagged data are presented in the tables in this report and were used to calculate averages, but at no time was a single piece of flagged data used to make a recommendation and, in most cases, trends in contaminant concentrations seen in flagged data were confirmed by onsite laboratory analys is.

\subsection{SUMMARY OF PARCC PARAMETERS}

\subsubsection{Precision}

The data validation reports evaluated the precision in field duplicates. In Test \#1, this evaluation resulted in a total of 30 individual constituents among eight different samples being flagged with a $Q$ flag. In Test \#2, a total of 22 individual constituents among four different samples were given a Q flag. This meets test criteria.

\subsubsection{Accuracy}

Accuracy is addressed in Part $E$ of the data validation reports. As discussed above and in the data validation reports, other than the gamma scan data in Test \#1 that has an XYZ qualifier, no data were found to have matrix spike, matrix spike duplicate, or surrogate samples met laboratory acceptance criteria as detailed in Table 11-1.

\subsubsection{Representativeness}

11.2.3.1 Sampling Methods. Representativeness was achieved by using standardized sampling procedures for collection of samples as detailed in the WHC EIIs (WHC 1988, Section 5.2) and by following the sample plan detailed in the test plan (DOE-RL 1993b).

11.2.3.2 Analytical Methods, Reporting Units, and Detection Limits. Representativeness of analysis, reporting, and detection limits was achieved by the use of standard analytical methods (Level II and III) and the use of recognized analytical techniques (Level II and $V$ ) for determination of radionuclide constituents. 
Results were reported in units that are appropriate for comparison purposes with historical and current analytical data.

Detection limits were met with the exception of those variances discussed in the data validation reports.

\subsubsection{Completeness}

As discussed in the data validation reports, completeness is calculated by the number of unflagged data divided by the total number of data expressed as a percentage.

For Test \#1 soils, there are 1,256 unflagged data and 1,302 total data giving a calculated completeness of $96 \%$. For Test \#1 water, there are 421 unflagged data and 578 total data giving a completeness of $73 \%$. For Test \#2 soils, there are 918 unflagged data and 1,122 total data giving a calculated completeness of $82 \%$. For Test \#2 water, there are 639 unflagged data and 683 total data giving a completeness of $93 \%$.

Therefore, completeness for the overall test for soils is $90 \%$ and for water is $84 \%$. These meet the $80 \%$ criteria used in the data validation report. Water treatment data are not included at this time.

\subsubsection{Comparability}

Comparability of data sets was facilitated by the proper reporting of results in correct units and by the analys is of duplicate samples. Results for duplicate samples were acceptable with the exception of the results identified in the data validation reports and Section 11.2.1.

\subsection{SURVEILLANCES}

Environmental QA surveillances of field activities, including sampling, verified that activities examined were performed acceptably in accordance with governing documents.

Offsite laboratory activities are subject to Environmental QA surveillances and appropriate laboratory corrective actions if required. 


\subsection{COMPARISON OF TEST RESULTS WITH PERFORMANCE STANDARDS}

Table 12-1 summarizes test results and test performance levels for primary contaminants of concern discussed in Section 1.2.1. Table 12-1 shows that test performance levels were met in both Test \#1 and Test \#2 for the 2 - to $0.425-\mathrm{mm}$ size process pile, and the total fraction of soil particles $>0.425 \mathrm{~mm}$. Although contaminant levels in the 2- to $0.425-\mathrm{mm}$ fraction of soils are higher than in the total soil, in practice, soils from each process stream are combined when returned to the site as clean soils. Therefore, contaminant levels in the "Total Soil Fraction $>0.425 \mathrm{~mm}$ " is the better measure to compare with test performance levels and other performance standards.

Table 12-2 shows acceptable soil concentrations of uranium-238, uranium-235, cobalt-60, and chromium to meet MTCA residential standards, RESRAD, and 1E-06 cancer risk levels. These levels are included for comparison with targe', performance levels and test results in accordance with the test plan; these are not soil cleanup levels.

MTCA residential levels apply to chromium only. This level was met in Test \#1 and Test \#2 soils $<9.5 \mathrm{~mm}$.

RESRAD values (Gilbert et al. 1989) are included because these are based on DOE Order 5400.5, which requires soil radioactivity levels $<20 \mu \mathrm{R} / \mathrm{hr}$ above background levels. Values derived were for a maximum dose of $<25 \mathrm{mrem} / \mathrm{hr}$. RESRAD levels were met in Test \#1 and Test \#2.

Incremental cancer risk (ICR) levels are given for three pathways: ingestion, inhalation, and external exposure. Values for an ICR of 1E-06 were determined using methods and assumptions (DOE-RL 1993c). Except for chromium (which exceeded external exposure levels for chromium VI) in Test \#2, the total soils $>0.425$ met $1 E-06$ levels for all constituents and pathways. Chromium in the 300-FF-1 Operable Unit is expected to be chromium III, for which there is no known cancer risk. In Test \#1, total soils $>n .425 \mathrm{~mm}$ met 1E-06 levels for the ingestion pathway for all constituents, but exceeded levels for the inhalation and external exposure pathways. ICR values given are based on conservative assumptions and may overestimate risk levels by as much as an order of magnitude (DOE-RL 1993C).

Water-based standards such as drinking water or groundwater standards are not included in Table 12-2. These levels were significantly lower than the test results for uranium-238, uranium-235, cobalt-60, and chromium, and may not be applicable for soil treatment applications.

As stated previously, cleanup levels for soils in the 300-FF-1 Operable Unit have not been established. These will be discussed in the Phase III FS. The milestone to submit a draft of the Phase III FS to EPA and Ecology is August 15, 1994. 


\subsection{DEVIATIONS FROM THE TEST PLAN}

Many of the deviations from the test plan were discussed with RL, EPA, and Ecology, and verbal approval was given to proceed prior to implementing changes. These changes and other field changes agreed to by the field team leader and project engineer are identified in this section.

Deviations to the test plan included the following:

- $\quad$ MTCA, Method C, industrial minimum (test) performance levels in Table 3-1 of the test plan (DOE-RL 1993b) were revised per updates by Ecology (1993). The revised levels are generally higher than those in the test plan.

- In Tests \#1 and \#2, about half the material discussed in the cest plan was processed. This was due to two factors. First, the system used was designed and built under a very tight schedule and only available equipment could be used; consequently, there were many breakdowns and delays resulting in the processing of less material. Second, in Test \#1 it was obvious early on from field measurements that radioactivity was present in each of the processed piles of soil; consequently, nothing would have been gained by processing more material.

- Green material was processed in Test \#1, while the test plan states that it would not be processed. Reasons for this were given in Section 6.0.

- The test plan schedule shows that Test \#1 would be performed the first 2 wk of June and Test \#2 the last 2 wk. Due to additional testing and analyses of the green material and significant modifications to equipment, Test \#2 was not completed until September.

- Laboratory attrition scrubbing tests were not identified in the test plan. These were necessary because the trommel and screens did not adequately break down material in Test \#1. Laboratory attrition tests were conducted in accordance with 100 Area Soil Washing Bench-Scale Test Procedures (Freeman et al. 1993).

- Sample numbers and times for the runs varied from the test plan. Fewer effluent samples were taken than anticipated because of shorter processing periods. Effluent samples were collected at approximately 1-hr intervals. Also, two sets of samples were collected during June rather than one; one set on June 23 and another June 25 . Additional samples were al so collected from the $0.425-$ to $2-\mathrm{mm}$ and $2-$ to $25-\mathrm{mm}$ process piles after a final short run on June 29. One set of soil and water samples was collected in September for Test \#2.

- The 0.425-mm screen was used in Test \#2 as opposed to the $0.212-\mathrm{mm}$ screen, and feed soils were obtained from new locations in the north process pond to avoid the green material. Reasons for these changes are discussed in Section 6.0. 


\subsection{COST}

This section looks at the potential costs that might be expected for a full-scale operation. These estimates were based on knowledge gained during this test and address only the operating costs.

The following assumptions were made regarding full-scale operation:

- Processing rate is 100 tons $/ \mathrm{hr}$.

- Single shift of processing/day.

- Hours of processing/shift is $5 \mathrm{hr}$.

- Number of processing days/year is 250 days.

- All preventive maintenance occurs during an off shift.

- Fresh water to feed the plant and for dust control will be supplied by pipeline.

- Electrical power will be supplied by lines.

- Numerous samples will be taken during the shift for field screening to control the process.

- Two additional samples will be taken every process day (one for clean material, one for waste material). The clean samples will be composited foi 1 wk to make one sample, which will be analyzed using EPA Level III and Level V analytical methods (EPA 1990). The same will be done with the waste sample.

- $20 \%$ of the samples receiving EPA Level III analysis will be validated (the number validated for $300-F F-1$ characterization work).

- When feasible, work will be performed by onsite empioyees.

Five factors were looked at in developing these costs. They were labor, materials and consumables, utilities, analytical costs, and maintenance costs. overhead costs are not included. In addition, a $20 \%$ contingency was added.

\subsection{LABOR}

Labor is composed of two groups: those directly involved with the operation of the plant and the support labor necessary for the day-to-day operation. Table 14-1 details the expected direct labor personnel requirements, and Table 14-2 details the anticipated requirements for support labor. 
Table 14-1. Direct Labor Requirements.

\begin{tabular}{|l|c|c|c|}
\hline \multicolumn{1}{|c|}{ Personnel } & FTEs & $\begin{array}{c}\text { Annual Cost } \\
\text { per FTE, } \$\end{array}$ & $\begin{array}{c}\text { Total Annual } \\
\text { Cost, } \$\end{array}$ \\
\hline Plant Operators & 2 & 65,000 & 130,000 \\
\hline Equipment Operators & 3 & 65,000 & 195,000 \\
\hline Sampler/Lab. Tech. & 3 & 65,000 & 195,000 \\
\hline Supervisor & 1 & 65,000 & 65,000 \\
\hline Total & 9 & & 585,000 \\
\hline
\end{tabular}

FTE = full time employee.

Table 14-2. Support Labor Costs.

\begin{tabular}{|l|c|c|c|}
\hline \multicolumn{1}{|c|}{ Personnel } & FTEs & $\begin{array}{c}\text { Annual Cost } \\
\text { per FTE, } \$\end{array}$ & $\begin{array}{c}\text { Total Annual } \\
\text { Cost, } \$\end{array}$ \\
\hline Health Physics Tech. & 2 & 65,000 & 130,000 \\
\hline Site Safety Officer & 1 & 65,000 & 65,000 \\
\hline Maintenance & 2 & 65,000 & 130,000 \\
\hline Fuel Truck Driver & 0.5 & 65,000 & 33,000 \\
\hline \multicolumn{1}{r|}{ Total } & 5.5 & & 358,000 \\
\hline
\end{tabular}

It is anticipated that full-scale operation will require two full-time plant operators. During the test, three people were required to oversee the operation; however, it is anticipated that the full-scale plant would be more automated and only require two operators.

Three equipment operators will be necessary to perform the material handling. Two people will be involved in feeding the plant (one dozer and one loader) and one loader operator will handle the processed streams coming out of the plant.

Three people will take samples of the process streams and do field screening tests (XRF and gamma scans) for process control.

There will be one full-time supervisor/engineer for the operation.

It is expected that two Health Physics technicians will be required during the operation. Two were necessary for the test and two should be adequate for the full-scale operation.

One site safety person will be sufficient for the operation. One person was adequate to cover the test. 
Two maintenance people will be required to perform preventive maintenance on the plant and the equipment when they are shut down. These two maintenance FTEs will also cover any electrical work required. The fuel truck driver is included to fuel the equipment and to serve as a third maintenance person.

\subsection{MATERIALS AND CONSUMABLES}

This section estimates the amount of materials and consumables that will be used by a ful1-scale operation. Table 14-3 details the items considered in this section.

Table 14-3. Materials and Consumables Costs.

\begin{tabular}{|l|c|}
\hline \multicolumn{1}{|c|}{ Item } & $\begin{array}{c}\text { Total Annual } \\
\text { Cost, } \$\end{array}$ \\
\hline Water for makeup and dust control & 7,000 \\
\hline Water treatment flocculents & 62,000 \\
\hline Laundry & 66,000 \\
\hline Safety equipment and supplies & 5,000 \\
\hline S.igns, ropes, fences, etc. & 5,000 \\
\hline Dust control equipment and supplies & 5,000 \\
\hline Tools & 1,000 \\
\hline Garbage & 5,000 \\
\hline $\begin{array}{l}\text { Miscellaneous materials (steel, timber, } \\
\text { etc.) }\end{array}$ & 10,000 \\
\hline
\end{tabular}

It is estimated that a full-scale plant that recycles its water will require $265 \mathrm{~L} / \mathrm{min}$ to feed the system. This is based on the amount of water lost to the various piles during the test and adjusted for a $100-$ ton $/ \mathrm{hr}$ system. It is substantiated by the fact that during a visit to see the soilwashing plant at the King of Prussia Site in New Jersey, site personnel stated that their 25 -ton $/ \mathrm{hr}$ plant required approximately $76 \mathrm{~L} / \mathrm{min}$ of feed water.

Based on the work done during the test, it is estimated that approximately $189 \mathrm{l}$./ton of material processed will be required for dust control. Some of this water goes on the material to be washed and some goes onto the roadway wilere the equipment is traveling. That amounts to $314 \mathrm{~L} / \mathrm{min}$ for dust control.

Total water required to feed the plant would be $579 \mathrm{~L} / \mathrm{min}$. This amounts to 42.58 million $L / y r$ and will cost about $\$ 7,000$ at city of Richland water costs. 
The estimates used to establish the baseline operating parameters for the water treatment system processing the water from the test give a cost of approximately $\$ 0.50 /$ ton of material processed for flocculents to treat water.

Laundry wi11 cost approximately $\$ 6 /$ person to dress out one time $(\$ 2 / 1 \mathrm{~b}$, $31 \mathrm{~b} / \mathrm{set}$ of whites). There are 14.5 FTEs, but not all will dress out every day. Assuming that an average of 11 dress out four times per day for 250 days, that amounts to 11,000 sets/yr or $\$ 66,000 / y r$ for 1 aundry.

An estimate of $\$ 5,000 / y r$ was made for safety equipment and supplies. This covers ear plugs, safety glasses, hard hats, face shields, plastic pants and coats, safety harnesses, instruments required by the site safety officer, first aid kits, eye wash units, showers, etc.

A total of $\$ 5,000 / y r$ was included for signs, ropes, and fences. This may be higher for the first year and less after that, but $\$ 5,000 / \mathrm{yr}$ is estimated.

For dust control, a sprinkler system would be set up to pre-wet the excavation area and roadways prior to the beginning of work. A total of $\$ 5,000$ was included to cover this simple system, which would lay on top of the ground.

be

Garbage disposal costs for tape, paper, plastics, etc., are estimated to $\$ 5,000 / y r$.

For the operators to make adjustments to the equipment from time to time and to clean the equipment as required, a set of tools will be required. A total of $\$ 1,000$ is included.

As is the case with any operation, there are numerous miscellaneous items that are not covered elsewhere. Therefore, $\$ 10,000$ has been included here for those items.

\subsection{UTILITIES}

This section addresses the costs related to the utilities that will be needed during full-scale operation. Table 14-4 details these costs.

It is estimated that a full-scale system based on the plant utilized for the test could require $260 \mathrm{~kW}$ in various motors. These would include conveyors, vibrating screens, pumps, trommels, autogenous grinders, attrition scrubbers, etc. The total estimated power required would be $260 \mathrm{~kW} / \mathrm{hr}$ for $7 \mathrm{hr} /$ day with a demand of approximately $260 \mathrm{~kW}$ for any $15-\mathrm{min}$ period. A figure of $\$ 0.035 / \mathrm{kW}-\mathrm{hr}$ is used for the usage cost, plus $\$ 5,000$ additional for the demand cost for a total of $\$ 21,000 / y r$. 
DOE/RL-93-96, Rev. 0

Table 14-4. Utility Costs.

\begin{tabular}{|l|r|}
\hline \multicolumn{1}{|c|}{ Item } & $\begin{array}{c}\text { Total Annual } \\
\text { Cost, } \$\end{array}$ \\
\hline Electricity & 21,000 \\
\hline Diesel Fuel & 31,000 \\
\hline Gasoline & 2,000 \\
\hline & Total \\
\hline
\end{tabular}

Diesel consumption for two front-end loaders and a dozer is estimated to be $114 \mathrm{~L} / \mathrm{hr}$ of operation based on tables from the Caterpillar (a trademark of Caterpiliar, Inc.) Performance Handbook, 22 Edition. A cost of $\$ 0.22 / L$ for diese 1 was used. Gasoline is a minor cost for pickups, and a total cost for fuel of $\$ 2,000 / y r$ is estimated.

\subsection{ANALYTICAL COSTS}

Analytical costs associated with a full-scale operation are assessed. Table 14-5 details these costs.

Table 14-5. Analytical Costs.

\begin{tabular}{|l|r|}
\hline \multicolumn{1}{|c|}{ Item } & $\begin{array}{c}\text { Total Annual } \\
\text { Cost, } \mathbf{\$}\end{array}$ \\
\hline Analysis & 130,000 \\
\hline Sampling equipment and supplies & 15,000 \\
\hline Data validation & 26,000 \\
\hline & Total \\
\hline
\end{tabular}

Analytical costs are based on the costs incurred under the contracts that were used for the test. The total cost for analysis with expedited turnaround time was approximately $\$ 1,300 /$ sample. The total cost for two samples per week comes to $\$ 130,000 / \mathrm{yr}$.

Sampling equipment and supplies will also include field screening equipment such as an XRF analyzer, hand-held gamma detectors, bottles, spoons, coolers, ice, etc. This cost will likely be high during the first year and much less the following years. An average cost of $\$ 15,000 / y r$ is estimated.

Data validation costs are difficult to predict dependent on what is required, but could cost as much per sample as the analysis itself. Using this as a conservative number and assuming that $20 \%$ of the data will require validation, a total cost of $\$ 26,000 / y r$ would be incurred. 


\subsection{MAINTENANCE COSTS}

Maintenance costs anticipated for a full-scale operation are provided in Table 14-6.

Table 14-6. Maintenance Costs.

\begin{tabular}{|c|c|}
\hline Item & $\begin{array}{l}\text { Total Annual } \\
\text { Cost, } \$\end{array}$ \\
\hline Parts & 100,000 \\
\hline Tools & 1,000 \\
\hline $\begin{array}{l}\text { Miscellaneous (lubricants, solvents, } \\
\text { rags, etc.) }\end{array}$ & 20.000 \\
\hline Total & 121,000 \\
\hline
\end{tabular}

Parts for this cost analysis include conveyor belts, loader tires, replacement screens, belts, filters, hoses, pump impellers, and all other miscellaneous parts that will be required to operate and maintain the plant and associated equipment. This cost is strictly an estimate, since the test did not last long enough to establish any baseline numbers. A figure of $\$ 100,000 /$ yr wi11 be used.

A figure of $\$ 1,000 / y r$ is included for tools. This is in addition to the $\$ 1,000 /$ yr for tools for the operators.

Another miscellaneous category includes lubricants and solvents. An estimate of $\$ 20,000 / y r$ is used.

\subsection{COST SUMMARY}

Combining individual costs, the entire cost for operating a full-scale plant was determined. Table 14-7 shows a summary of this.

As can be seen from the costs in Table 14-7, the anticipated operating cost for the full-scale soil-washing plant is $\$ 13.92 /$ ton of material processed. This is believed to be a conservatively high cost based on the assumptions made and added contingencies. It is also anticipated that this cost could be reduced by increasing the processing rate, increasing the number of days of operation, and/or increasing the number of shifts worked per day.

It should be noted that there are additional costs for a project that are not included in the operating costs. These include the capital costs involved with the purchase, mobilization, and construction of the plant; the cost for installation of electrical and water lines; costs associated with hauling and disposal of process wastes; and overhead costs for various organizations involved. These items will need to be assessed in comparing soil washing with other remedial alternatives. 
DOE/RL-93-96, Rev. 0

Table 14-7. Full-Scale Operation Cost Summary.

\begin{tabular}{|c|c|c|}
\hline Item & $\begin{array}{l}\text { Total Annual } \\
\text { Cost, } \$\end{array}$ & $\begin{array}{l}\text { Total Cost/Ton } \\
\text { Processed, \$ }\end{array}$ \\
\hline Labor-direct & 585,000 & 4.68 \\
\hline Labor-support & 358,000 & 2.86 \\
\hline Materials and consumables & 161,000 & 1.29 \\
\hline Utilities & 54,000 & 0.43 \\
\hline Analytical & 171,000 & 1.37 \\
\hline Maintenance & 121,000 & 0.97 \\
\hline Subtotal & $1,450,000$ & 11.60 \\
\hline Contingency $(20 \%)$ & 290,000 & 2.32 \\
\hline Total & $1,740,000$ & 13.92 \\
\hline
\end{tabular}

One of the benefits of performing the vendor test, in addition to the tests reported, is to obtain better cost and scale-up information from a commercially proven system. As noted previously, the system used for tests in this report was made up of equipment components that were available at the time and were not necessarily designed to work together. 


\subsection{CONCLUSIONS AND RECOMMENDATIONS}

The overall objective of the test was to evaluate the use of physical separations systems as a means of concentrating chemical and radiochemical contaminants into fine soll fractions, thereby minimizing waste volumes. The minimum test performance levels are shown in Table 2-1. The goal for the test was to achleve a $90 \%$ (by weight) reduction in contaminated solls (WHC 1991).

The RI report, analyses by Serne et al. (1992), and this treatability test showed that the primary risk driver in the 300-FF-1 Operable Unit is uranium-238 and uranium-235. Analytical data presented in Section 3.0 show that all other contaminants in solls sampled were below test performance levels prior to processing. These performance levels were established as goals for the test, they are not soil cleanup standards. While final cleanup standards for 300-FF-1 solls have yet to be determined, these will be critical to assessing the effectiveness of remedial alternatives.

In general, the physical separation system tested met the test goals, thereby demonstrating the potential to reduce the amount of contaminated soils in the 300-FF-1 Operable Unit without the use of chemical processes. Therefore, physical separation of excavated soils prior to disposal is an alternative that should be carried in the Phase III FS.

In Test $\# 2$, offsite analytical results of soll piles after processing showed that soils representative of the largest fraction of the 300-FF-1 Operable Unit waste sites (not containing green material) were separated so that the concentration of uranium was significantly lower in the coarse fraction of solls (12 $\mathrm{pCi} / \mathrm{g}$ for $>0.425-\mathrm{mm} \mathrm{particles}$ and $93.63 \mathrm{pCi} / \mathrm{g}$ for <0.425-mm particles). Onsite laboratory analyses showed similar results. These levels are significantly lower than test performance levels of $370 \mathrm{pCi} / \mathrm{g}$ for uranium-238 and $170 \mathrm{pCi} / \mathrm{g}$ for uranium-235, and lower than comparison levels discussed in Section 3.5. The cutpoint of $0.425 \mathrm{~mm}$, resulted in a 98.6\% reduction by weight in the amount of contaminated feed material.

While uranium-238 and uranium-235 radioactivity levels were of primary concern, Test \#2 1aboratory analyses using XRF (Table 7-7) showed that the concentration of copper and uranium elements in the solls was reduced proportionally. Therefore, copper or uranium are potential indicator analytes for future tests or during site remediation.

While physical separation processes were effective for these soils, it is recommended that careful consideration be given in the Phase III FS is to the benefit versus cost of processing solls within the 300-FF-1 Operable Unit that are near background levels and below test performance levels prior to processing.

Test \#1 showed that soils containing the green material can likely be processed with the addition of an attrition scrubber to the system tested. This finding exceeded the scope of the test plan, which originally excluded processing of solls containing the green material due to laboratory indications that physical separation processes may not be effective for this matertal (Dennison et al. 1989). 
After processing, radioactivity was measured in the fleld in each of the process plles. Analytical tests confirmed that, as expected, the green material was the primary source of the radloactivity and that uranium-238 was the primary radioactive isotope. However, after wet-sieving in the laboratory, green material was broken down so that gamma spectrometry analyses showed that solls met performance levels for $94 \%$ by weight of the feed solls $(>0.15 \mathrm{~mm})$.

Laboratory tests also showed that artrition scrubbing further separated particles containing the green material such that soll particles $>0.075 \mathrm{~mm}$ met test performance levels. The highest concentrations of uranium-238 and urantum-235 in soll fractions $>0.425 \mathrm{~mm}$ were $<50$ and $<5 \mathrm{pCi} / \mathrm{g}$, respectively. In the laboratory attrition tests, as much as $10 \%$ to $12 \%$ more fines were generated in the material scrubbed (Table 6-12). This is equivalent to $4 \%$ to $5 \%$ more fines in the feed soils. The overall reduction in the amount of contaminated solls would be approximately $85 \%$ by weight (Section 3.2.2).

Field-scale attrition scrubber tests are recommended to verify laboratory tests can be duplicated in the field and further verify the effectiveness of using attrition scrubbing to treat soils containing the green material. An attrition scrubber has been purchased and is expected to be incorporated as part of the vendors test.

Physical separation processes are not recommended for treating concentrated soll fines such as the intact green layer or fly ash. Excavation and direct disposal may be the preferred alternative for this material.

Cost estimates (Section 4.0) for a ful1-scale physical separations system to operate at $100 \mathrm{ton} / \mathrm{hr}$ were estimated at approximately $\$ 14 /$ ton of material. This figure is for operating costs only. It does not include disposal, overhead, or capital costs for equipment and mobilization. Capital costs among vendors range from roughiy $\$ 1,000,000$ to over $\$ 5,000,000$. As of December 1993, Hanford disposal costs during remediation were unknown. However, physical separation and volume reduction is expected to be economically competitive with direct disposal.

The water treatment test and vendor test are tentatively scheduled to be completed in the spring of 1994 . Per the January 1994 unit managers meeting minutes, test results will be documented in WHC support documents to be reviewed by DOE-RL, Ecology, and EPA. Information from these tests, and information contained within this report will be used in the Phase III FS, scheduled to be completed by August 15, 1994. A detailed schedule for additional water treatment and vendor tests was not included because the schedule is dependent on vendor contract modifications, approval of the vendor's system, cold weather conditions, and priority allocation of resources. 


\subsection{REFERENCES}

Dennison, D. 1., D. R. Sherwood, and J. S. Young, 1989, status Report on Remedial Investigation of the 300 Area Process Ponds, PNL 6442, Pacific Northwest Laboratory, Richland, Washington.

DOE, 1990, Radiation Protection of the Public and the Environment, DOE Order 5400.5, U.S. Department of Energy, Washington, D.C.

DOE-RL, : 190, Renedial Investigation/Feasibility Study Work Plan for the 300FF-1 Operable Unit, Hanford Site, Richland, Washington, DOE/RL 88-31, U.S. Department of Energy, Richland Operations, Richland, Washington.

DOE-RL, 1993a, Phase I and II Feasibility Study Report for the 300-FF-1 Operable Unit, DOE/RL $92-46$, U.S. Department of Energy, Richland Operations, Richland, Washington.

DOE-RL, 1993b, 300-FF-1 Physical Separations CERCLA Treatability Test Plan, DOE/RL 92-21 Rev. 1, U.S. Department of Energy, Ric:.1 and Operations, Richland, Washington.

DOE-RL, 1993c, Phase I Remedial Investigation Report for the 300-FF-1 Operable Unit, DOE/RL-92-43, Draft C, U.S. Department of Energy, Richland Operations, Richland, Washington.

DOE-RL, 1993d, Hanford Site Baseline Risk Assessment Methodology, DOE/RL-91-45 Rev. 2, U.S. Department of Energy, Richland Operations, Richland, Washington.

Ecology, EPA, and DOE, 1989, et seq., Hanford Federal Facility Agreement and Consent Order, Washington Department of Ecology, U.S. Environmental Protection Agency, U.S. Department of Energy, Oiympia, Washington.

Ecology, 1993, July 1993 Update to the Model Toxics Control Act (MTCA) Cleanup Standards Database, correspondence from B. Huether to Interested Parties, July 9, 1993.

EPA, 1988, Technological Approaches to the Cleanup of Radiologically Contaminated Superfund Sites, EPA/540/2-88/002, U.S. Environmental Protection Agency, Washington, D.C.

EPA, 1989, The Superfund Innovative Technology Evaluation Program: Technology Profiles, EPA/540/5-89/013, U.S. Environmental Protection Agency, Washington, D.C.

EPA, 1990, Test Methods for Evaluating Solid Wastes, Physical/Chemical Methods, EPA Publication SW-846, 3rd edition, U.S. Environmental Protection Agency, Office of Solid Waste and Emergency Response, Washington, D.C.

Freeman, H. A., M. A. Gerber, S. V. Mattigod, R. J. Serne, 1993, 100 Area Soil Washing Bench-Scale Test Procedures, PNL-8520, Pacific Northwest Laboratory, Richland, Washington. 

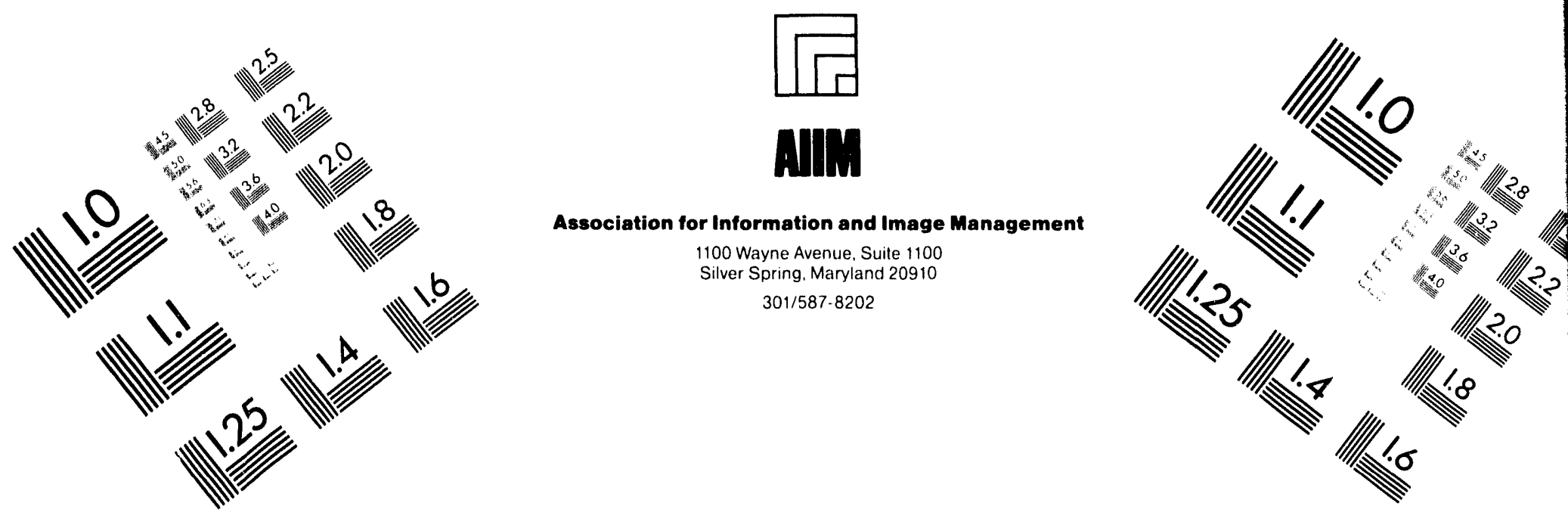

\section{Centimeter}

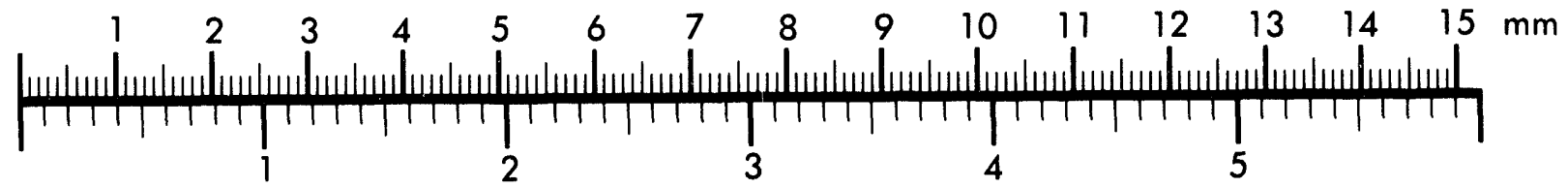
Inches
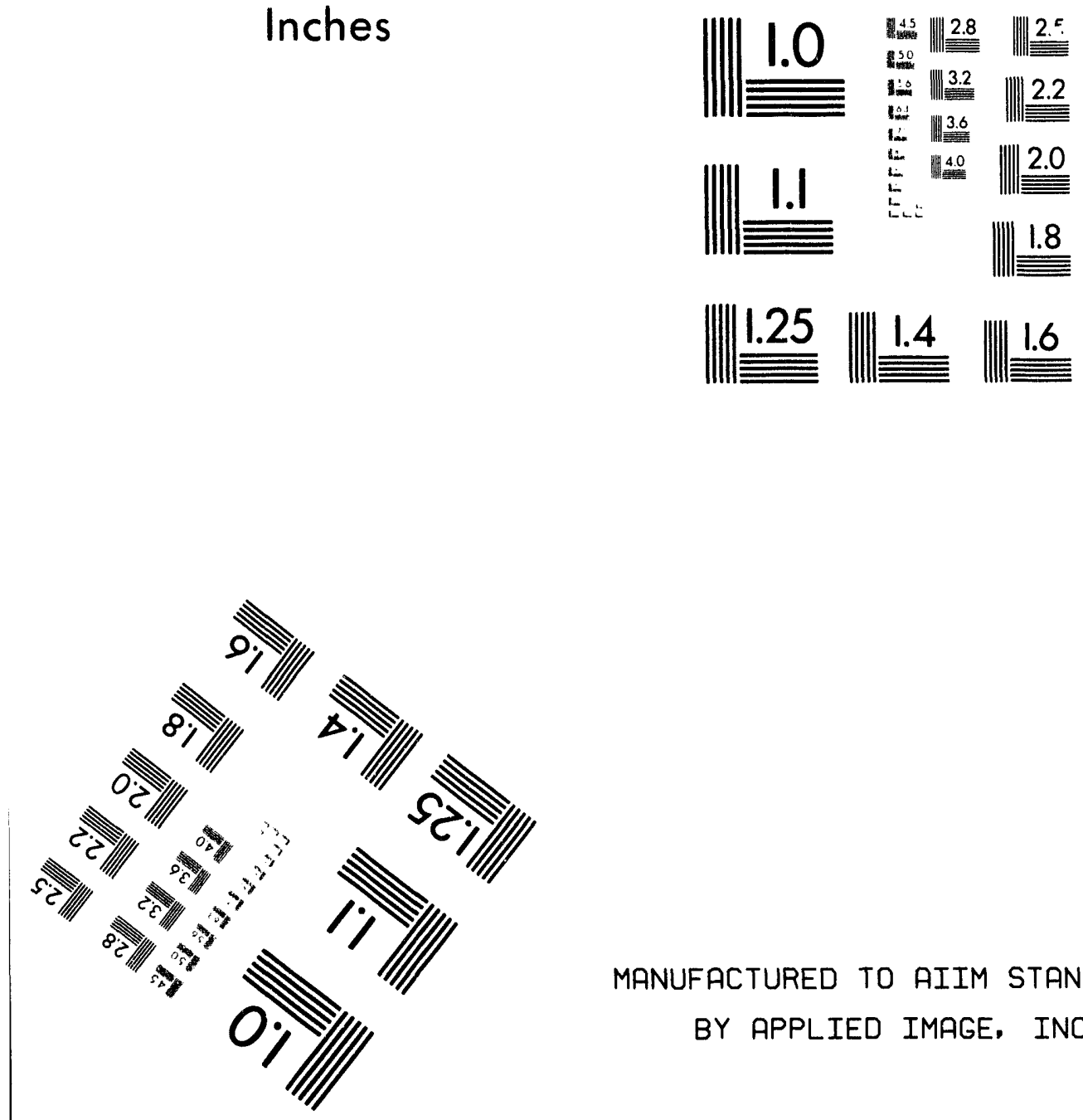

MANUFACTURED TO AIIM STANDARDS

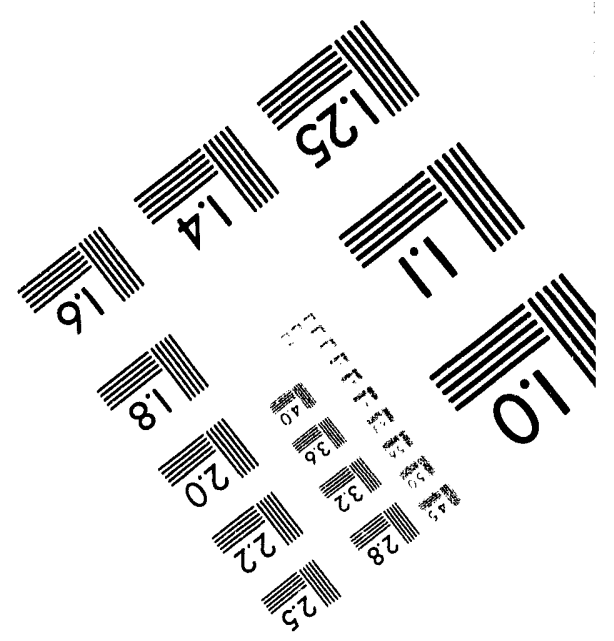



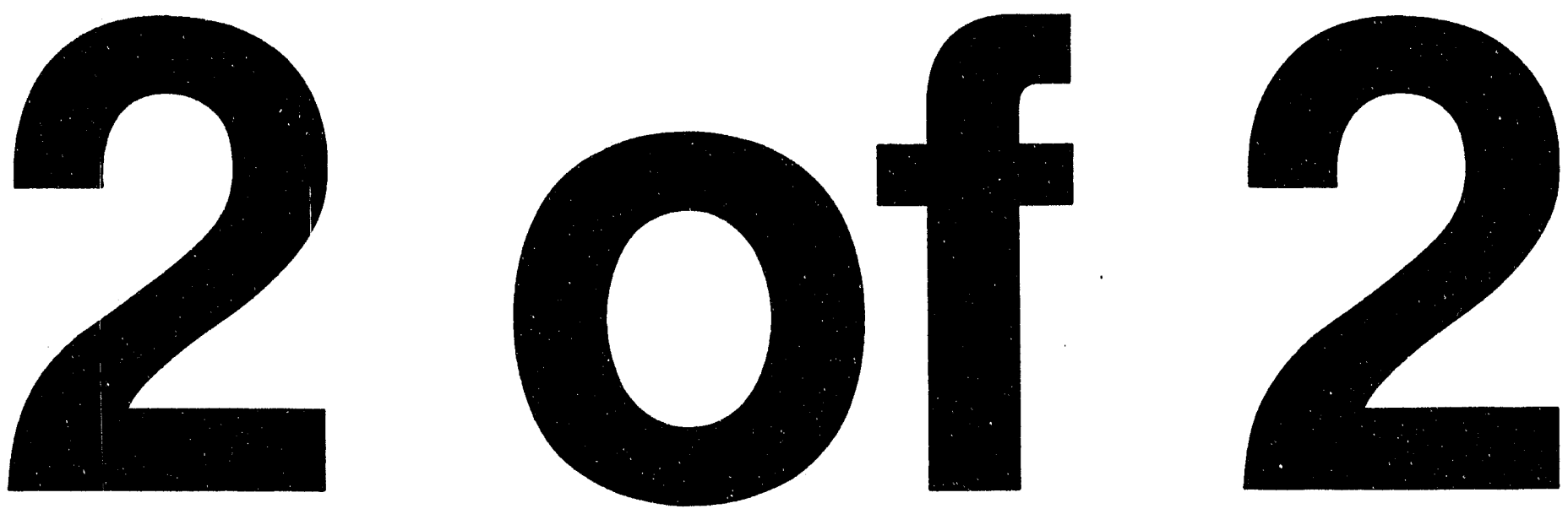
Gerber, M. A., H. D. Freeman, E. G. Baker, and W. F. Riemath, 1991, Soil Washing: A Preliminary Assessment of Its Applicability to Hanford, PNL7787, Pacific Northwest Laboratory, Richland, Washington.

Gilbert, T. L., C. Yu, Y. C. Yuan, A. J. Zielen, M. J. Jusko, and A. Wallo III, 1989, A Manual for Implementing Residual Radioactive Material Guidelines, ANL/ES-160, DOE/CH/8901, Argonne National Laboratory, Argonne, Illinois.

Kochen, R. L., 1986, Decontamination of Johnston Island Coral: A Preliminary Study, U.S. Department of Energy Report RFP-3849, Rockwel1 International, Golden, Colorado.

McGuire, J. P., 1993, Physical Separation Soil Washing System Cold Test Results, WHC-SD-EN-TI-188, Rev. 0, Westinghouse Hanford Company, Richland, Washington.

Rubin, D. K., 1993, "Soil Washing Proving a Good Bet," Engineering News Record, July 19, 1993.

Serne, R. J., C. W. Lindenmeier, P. K. Bhatia, and V. L. Legore, 1992, Contaminant Concentration Versus Particle Size for 300 Area North Process Pond Samples, WHC-SD-EN-TI-049, Rev. 0, Westinghouse Hanford Company, Richland, Washington:

Serne, R. J., S. V. Mattigod, V. L. Legore, D. S. Burke, T. L. Gervais, 1993, Sediment and Process Water Characterization in Support of 300 Area North Process Pond Physical Soil Washing Test, WHC-SD-EN-TI-214, Rev. 0, Westinghouse Hanford Company, Richland, Washington.

WHC, 1988, Environmental Investigations and Site Characterization Manual, WHC-CM-7-7, et seq., Westinghouse Hanford Company, Richland, Washington.

WHC, 1990, Sample Management and Administration Manual, WHC-CM-5-3, West inghouse Hanford Company, Richland, Washington.

WHC, 1991, Environmental Compliance Manual, WHC-CM-7-5, Westinghouse Hanford Company, Richland, Washington.

WHC, 1992, Quality Assurance Project Plan for RCRA Groundwater Monitoring Activities, WHC-SD-EN-QAPP-001, Westinghouse Hanford Company, Richland, Washington. 
DOE/RL-93-96, Rev. 0

\section{APPENDIX A}

\section{PURGEWATER ACCEPTANCE STANDARDS}


DOE/RL-93-96, Rev. 0
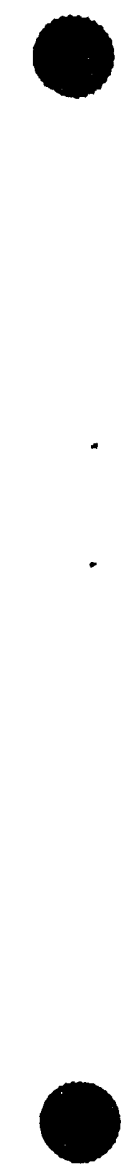

$A-2$ 
D0E/RL-93-96, Rev. 0

Table A-1. Purgewater Acceptance Standards.

\begin{tabular}{|c|c|c|}
\hline Analyte & Units & Concentration \\
\hline $\begin{array}{l}\text { Metals (inorganics) } \\
\text { Aluminum } \\
\text { Antimony } \\
\text { Arsenic } \\
\text { Beryllium } \\
\text { Cadmium } \\
\text { Chromium } \\
\text { Copper } \\
\text { Iron } \\
\text { Lead } \\
\text { Manganese } \\
\text { Mercury } \\
\text { Nickel } \\
\text { Silver } \\
\text { Uranium } \\
\text { Zinc }\end{array}$ & $\mathrm{ppb}$ & $\begin{array}{r}N / A \\
16,000 \\
480 \\
53 \\
11 \\
110 \\
120 \\
3,000 \\
32 \\
500 \\
0.1 \\
1,600 \\
10 \\
590 \\
1100\end{array}$ \\
\hline Organics & $\mathrm{ppb}$ & \\
\hline $\begin{array}{l}\text { 1,2-dichloroethylene } \\
\text { Methylene chloride } \\
\text { Tetrachloroethylene } \\
\text { Trichloroethylene }\end{array}$ & & $\begin{array}{r}70 \\
N / A \\
8,400 \\
50\end{array}$ \\
\hline$\underline{P C B}$ & $\mathrm{ppb}$ & $N / A$ \\
\hline$\frac{\text { Radiochemical }}{\text { Contaminants }}$ & $\mathrm{pC} i / \mathrm{L}$ & \\
\hline $\begin{array}{l}\text { Cesium-137 } \\
\text { Coba1t-60 } \\
\text { Uranium }\end{array}$ & & $\begin{array}{r}2,000 \\
1,000 \\
400\end{array}$ \\
\hline
\end{tabular}

NOTE: Values are from WHC Environmental Compliance Manual, Section 8, "Water Quality" (WHC 1991). 
DOE/RL-93-96, Rev. 0

APPENDIX B

ANALYTICAL DATA

B-1 
DOE/RL-93-96, Rev. 0
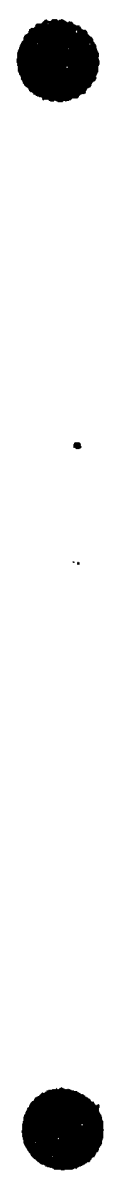

B-2 
DOE/RL-93-96, Rev. 0

B. 1 ANALYTICAL DATA FOR TEST \# 1

B. 1-1 
DOE/RL-93-96, Rev. 0

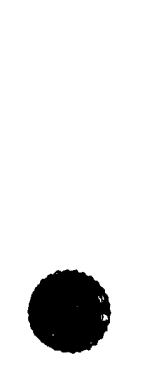

$\bullet$

B. 1-2 
DOE/RL-93-96, Rev. 0

\begin{tabular}{|c|c|c|c|c|c|c|c|}
\hline \multicolumn{8}{|c|}{$\begin{array}{c}\text { TEST \#1 SOIL WASHING RESULTS } \\
\text { RAW FEED MATERIAL }\end{array}$} \\
\hline & \multicolumn{7}{|c|}{ JUNE 1993 PROCESSING } \\
\hline & $\begin{array}{r}807 c 09 \\
\text { soil } \\
\mathrm{mg} / \mathrm{kg} \\
\end{array}$ & $\begin{array}{r}807 c 10 \\
\mathrm{soil} \\
\mathrm{mg} / \mathrm{kg} \\
\end{array}$ & $\begin{array}{r}\mathrm{B} 07 \mathrm{c11} \\
\mathrm{soil} \\
\mathrm{mg} / \mathrm{kg} \\
\end{array}$ & $\begin{array}{r}807 \mathrm{C67} \\
\mathrm{soil} \\
\mathrm{mg} / \mathrm{kg} \\
\end{array}$ & $\begin{array}{r}\mathrm{B} 07 \mathrm{C3} 8 \\
\mathrm{soil} \\
\mathrm{mg} / \mathrm{kg} \\
\end{array}$ & $\begin{array}{r}\mathrm{B} 07 \mathrm{C3} 9 \\
\mathrm{soil} \\
\mathrm{mg} / \mathrm{kg}\end{array}$ & $\begin{array}{r}\mathrm{B} 07 C 40 \\
\mathrm{soil} \\
\mathrm{mg} / \mathrm{kg} \\
\end{array}$ \\
\hline $\mathrm{Ag}$ & 67 & 29 & 9.6 & 9.4 & 8.7 & 18 & 5.1 \\
\hline Al & 31000 & 22000 & 19000 & 18000 & 24000 & 22000 & 22000 \\
\hline As & 3.8 & 2 & 1.7 & 1.7 & 1.9 & 1.5 & 2.7 \\
\hline Ba & 270 & 700 & 13000 & 5700 & 1600 & 1200 & 1800 \\
\hline Be & 0.75 & 0.93 & $u$ & $u$ & $u$ & 1.5 & $u$ \\
\hline $\mathrm{ca}$ & 17000 & 12000 & 9600 & 8000 & 10000 & 11000 & 10000 \\
\hline $\mathrm{cd}$ & 1.7 & $u$ & $0.52 L$ & $u$ & 0.511 & $u$ & $u$ \\
\hline co & 6.1 & 6.4 & 6.9 & 7.2 & 7.3 & 7.1 & 7.2 \\
\hline $\mathrm{cr}$ & 520 & 280 & 1600 & 1000 & 150 & 220 & 140 \\
\hline $\mathrm{cu}$ & 10000 & 3500 & 9100 & $1200 Q$ & 930 & 2500 & 300 \\
\hline Fe & 14000 & 16000 & 18000 & 17000 & 18000 & 18000 & 17000 \\
\hline $\mathrm{Hg}$ & 3.1 & 2.9 & 1.9 & 1.2 & 2.5 & 2.6 & 2.2 \\
\hline$k$ & 540 & 980 & 1200 & 1300 & 1300 & 900 & 1100 \\
\hline Mg & 8000 & 6600 & 5700 & 5400 & 6300 & 6300 & 6400 \\
\hline un & 250 & 260 & 260 & 270 & 250 & 240 & 240 \\
\hline Ya & 1000 & 1600 & 2100 & 1900 & 2800 & 2100 & 2800 \\
\hline Ni & 940 & 380 & 110 & 130 & 99 & 240 & 45 \\
\hline po & 83 & 40 & 36 & 29 & 60 & 49 & 38 \\
\hline$s b$ & 121 & $7.4 L$ & $10 L 0$ & 6.920 & $u$ & $5.2 L$ & $\underline{U}$ \\
\hline Sn & 41 & 25 & 200 & vo & 20 & 18 & 25 \\
\hline$v$ & 34 & 35 & 37 & 45 & 38 & 36 & 35 \\
\hline $\mathrm{Kn}$ & 150 & 95 & 75 & 56 & 77 & 85 & 69 \\
\hline & $\mathrm{pci} / \mathrm{g}$ & $\mathrm{pCi} / \mathrm{g}$ & $p c i / g$ & $\mathrm{pCi} / \mathrm{g}$ & $p r i / g$ & $\mathrm{PCj} / \mathrm{g}$ & $\mathrm{pCi} / \mathrm{g}$ \\
\hline $50-60$ & $0.0715 \times Y Z$ & $0.0671 \times Y Z$ & $0.0298 \times Y Z$ & $0 X Y Z$ & $0 X Y Z$ & $0.0408 \times Y Z$ & $0.062 \times Y Z$ \\
\hline cs-137 & $0.129 \times Y Z$ & $0.144 \times Y Z$ & 0.14 oxyz & 0.18 axyz & $0.264 \times Y Z$ & $0.272 X Y Z$ & $0.181 \times Y Z$ \\
\hline $\mathrm{pb}-212$ & $1.84 \times Y Z$ & $1.32 \times Y Z$ & 0.89 oxyz & 1.38 aXYZ & $0.817 \times Y Z$ & $1.53 \times Y Z$ & $1.81 \times Y Z$ \\
\hline$p b-214$ & $0.38 \times Y Z$ & $0.604 \times Y Z$ & $0.528 \times Y Z$ & $0.57 \times Y Z$ & $0.586 \times Y Z$ & $0.547 \times Y Z$ & $0.509 \times Y Z$ \\
\hline $20-224$ & $0.347 \times Y Z$ & $0.591 \times Y Z$ & 0.48 oxyz & 1.4 Qxyz & $0.42 \times Y Z$ & $0.615 \times Y Z$ & $0.522 \times Y Z$ \\
\hline Ba-226 & $1.87 \mathrm{XYZ}$ & $1.34 \times Y Z$ & $0.904 \times Y Z$ & $0.535 \times Y Z$ & $0.83 \times Y Z$ & $1.55 \times Y Z$ & $1.84 \mathrm{XYZ}$ \\
\hline $2 u-106$ & $0.0687 \times Y Z$ & $0 X Y Z$ & $0 X Y Z$ & $0 X Y Z$ & $0.182 \times Y Z$ & $0.25 \times Y Z$ & $0.08 \times Y Z$ \\
\hline $5 b-125$ & $0 X Y Z$ & $0.0178 \times Y Z$ & $0.0087 \times Y z$ & $0 X Y Z$ & $0 X Y Z$ & $0.1 \times Y Z$ & $0.157 \times Y Z$ \\
\hline & $\mathrm{pCi} / \mathrm{g}$ & $p c i / g$ & pci/g & $\mathrm{pci} / \mathrm{g}$ & $\mathrm{pci} / \mathrm{g}$ & $\mathrm{pCi} / \mathrm{g}$ & $\mathrm{pCi} / \mathrm{g}$ \\
\hline$J$-Nat & 3360 & 2220 & 26500 & 6630 & 1280 & 775 & 1670 \\
\hline
\end{tabular}


DOE/RL-93-96, Rev. 0

\begin{tabular}{|c|c|c|c|}
\hline \multicolumn{4}{|c|}{$\begin{array}{l}\text { TEST \#1 SOIL WASHING RESULTS } \\
\text { FRESH HATER (UNFILTERED) } \\
\end{array}$} \\
\hline & \multicolumn{3}{|c|}{ JUNE 1993 PROCESSING } \\
\hline & $\begin{array}{r}\text { B07C70 } \\
\text { water } \\
\mathrm{mg} / \mathrm{L}\end{array}$ & $\begin{array}{r}\text { B07c71 } \\
\text { water } \\
\mathrm{mg} / \mathrm{L}\end{array}$ & $\begin{array}{r}807 c 72 \\
\text { water } \\
\mathrm{mg} / \mathrm{L}\end{array}$ \\
\hline $\mathrm{Ag}$ & $u$ & $u$ & $u$ \\
\hline Al & $0.19 L$ & $0.12 L$ & $0.13 L$ \\
\hline As & $u$ & $u$ & $u$ \\
\hline $\mathrm{Ba}$ & 0.026 & 0.026 & 0.026 \\
\hline Be & $\mathrm{U}$ & $u$ & $u$ \\
\hline $\mathrm{Ca}$ & 20 & 17 & 17 \\
\hline $\mathrm{Cd}$ & $u$ & $u$ & $\underline{u}$ \\
\hline Co & $u$ & $u$ & $\underline{u}$ \\
\hline $\mathrm{Cr}$ & $u$ & $u$ & $u$ \\
\hline $\mathrm{Cu}$ & $0.0068 L$ & $0.0063 \mathrm{~L}$ & 0.00731 \\
\hline $\mathrm{Fe}$ & 0.46 & 0.4 & 0.39 \\
\hline $\mathrm{Hg}$ & $u$ & $u$ & $u$ \\
\hline$k$ & 1.2 & $0.75 \mathrm{~L}$ & $0.81 \mathrm{~L}$ \\
\hline Mg & 4.6 & 3.9 & 4 \\
\hline Mn & 0.013 & 0.011 & 0.011 \\
\hline $\mathrm{Na}$ & 3.2 & 2.6 & 2.6 \\
\hline $\mathrm{Ni}$ & $\underline{u}$ & $u$ & $u$ \\
\hline$P b$ & $0.002 \mathrm{~L}$ & 0,0072 & 0.0069 \\
\hline sb & $u$ & $\underline{u}$ & $\underline{u}$ \\
\hline Sn & $u$ & $u$ & $u$ \\
\hline$v$ & $0.0047 \mathrm{~L}$ & $u$ & $u$ \\
\hline $2 n$ & $0.0058 L$ & $0.0045 \mathrm{~L}$ & $0.0055 \mathrm{~L}$ \\
\hline & $\mathrm{pCi} / \mathrm{L}$ & $\mathrm{pCi} / \mathrm{L}$ & $\mathrm{pci} / \mathrm{L}$ \\
\hline $\mathrm{Co}-60$ & 7.6 & 9.76 & 1.91 \\
\hline Cs. 137 & 2.01 & 0.433 & 4.87 \\
\hline \multicolumn{4}{|l|}{$\mathrm{Pb}-212$} \\
\hline \multicolumn{4}{|l|}{$\mathrm{Pb}-214$} \\
\hline \multicolumn{4}{|l|}{$R a-224$} \\
\hline \multicolumn{4}{|l|}{$R a-226$} \\
\hline RU- 106 & 11 & 12.3 & 0 \\
\hline \multirow[t]{2}{*}{ sb- 125} & 0 & 0 & 0 \\
\hline & $49 / 2$ & ug/L & Ua/L \\
\hline U-Nat & 0.28 & 1.18 & 0.339 \\
\hline
\end{tabular}




\begin{tabular}{|c|c|c|c|c|c|c|c|c|c|c|c|c|c|c|c|c|}
\hline & & & & & $\mathrm{mm} \mathrm{T}$ & $\begin{array}{c}\text { TEST } \\
2 \operatorname{mim}(\mathrm{Ju}\end{array}$ & $\begin{array}{l}\text { *1 soll } \\
\text { ne } 1993 \\
\end{array}$ & $\begin{array}{l}\text { MAsuInG } \\
\text { Process }\end{array}$ & $\begin{array}{l}\text { RESUL TS } \\
\text { ing) (sh }\end{array}$ & $\begin{array}{l}\text { S } \\
\text { heet } 10\end{array}$ & of 21 & & & & & \\
\hline & $\begin{array}{r}\mathrm{BO7C14} \\
\text { soll } \\
\mathrm{mo} / \mathrm{kg}\end{array}$ & $\begin{array}{r}\text { Bo7c16 } \\
\text { soil } \\
\mathrm{mg} / \mathrm{kg}\end{array}$ & $\begin{array}{r}07 C 16 \\
\text { soll } \\
\mathrm{mg} / \mathrm{kg}\end{array}$ & $\begin{array}{r}B 07 c 17 \\
\text { coil } \\
\mathrm{mo} / \mathrm{kg}\end{array}$ & $\begin{array}{r}807 \mathrm{Cl}^{80} \\
20 \mathrm{il} \\
\mathrm{mo} / \mathrm{kg}\end{array}$ & $\begin{array}{r}807 c 19 \\
80 i \\
\text { mo/kg }\end{array}$ & $\begin{array}{r}807 \mathrm{C2O}^{80} \\
\mathrm{eoll} \\
\mathrm{mg} / \mathrm{kg}\end{array}$ & $\begin{array}{r}807 c 21 \\
2011 \\
\mathrm{mg} / \mathrm{kg}\end{array}$ & $\begin{array}{r}807 c 22 \\
80 i 1 \\
m a / k g\end{array}$ & $\begin{array}{r}807 \mathrm{C23} \\
\mathrm{soil} \\
\mathrm{mg} / \mathrm{kg} \\
\end{array}$ & \begin{tabular}{|}
$807 \mathrm{C24}$ \\
$-\mathrm{soll}$ \\
$\mathrm{mg} / \mathrm{kg}$ \\
\end{tabular} & \begin{tabular}{|r|}
$B 07 C 25$ \\
$80 i l$ \\
moikg \\
\end{tabular} & $\begin{array}{r}807 \mathrm{C43} \\
80 i l \\
\mathrm{mo} / \mathrm{kg} \\
\end{array}$ & $\begin{array}{r}807 \mathrm{CA4} \\
200 i \\
\mathrm{mg} / \mathrm{kg} \\
\end{array}$ & $\begin{array}{r}307 \mathrm{C45} \\
80 i 1 \\
\mathrm{mg} / \mathrm{kg} \\
\end{array}$ & $\begin{array}{r}\text { BO7C46 } \\
\text { soll } \\
\text { ma/kg } \\
\end{array}$ \\
\hline$A_{0}$ & 5.4 & 8.1 & 5.1 & 5.6 & 2.5 & 4.8 & 4.3 & 11 & $0.89 \mathrm{~L}$ & 1.7 & $0.68 \mathrm{~L}$ & 4.7 & 13 & 3.1 & $u$ & 17 \\
\hline AI & 21000 & 31000 & 8500 & 5800 & 3700 & 11000 & 6900 & 13000 & 3900 & $4900 \mathrm{~L}$ & 4400 & 12000 & 15000 & 22000 & 4000 & 20000 \\
\hline A: & 1.6 & 0.9 & 0.64 & $0.2 \mathrm{~L}$ & 0.68 & 0.66 & 1 & 0.81 & 0.98 & 0.59 & 0.64 & 0.96 & 3.5 & 1.1 & u & 2.6 \\
\hline B. & 100 & 160 & 110 & 79 & 60 & 200 & 110 & 170 & 170 & 100 & 80 & 90 & 180 & 70 & 61 & 200 \\
\hline 30 & $u$ & 0.52 & u & 0.2 & $0.15 \mathrm{~L}$ & 0 & $u$ & $\underline{u}$ & $u$ & u & $0.14 \mathrm{~L}$ & u & 0.79 & 0.32 & $u$ & 1 \\
\hline c. & 5900 & 8700 & 6700 & 3600 & 4100 & 6600 & 6200 & 7600 & 4100 & 5000 & 1500 & 6100 & 8500 & 4100 & 1000 & 11000 \\
\hline cd & $u$ & $\dot{u}$ & $\mathbf{u}$ & $\mathbf{u}$ & $u$ & $u$ & $u$ & $0.73 \mathrm{~L}$ & $u$ & $u$ & $0.35 \mathrm{~L}$ & $u$ & $u$ & $u$ & $0.39 \mathrm{~L}$ & $0.65 \mathrm{~L}$ \\
\hline co & 7.7 & 9.8 & 8.7 & 2.3 & 5.9 & 9.8 & 8.5 & 6.6 & 5.7 & 8.2 & 4.5 & 8.1 & 10 & 2.9 & 2.7 & 8.1 \\
\hline cr & 59 & 100 & 58 & 58 & 23 & 36 & 50 & 140 & 20 & 20 & 17 & 62 & 150 & 32 & 5.2 & 170 \\
\hline cu & 1300 & 2100 & 1200 & 1200 & 320 & 650 & 1100 & 2600 & 280 & 370 & 130 & 1300 & 3300 & 770 & 61 & 4400 \\
\hline $\mathrm{Fe}$ & 20000 & 23000 & 21000 & 8500 & 13000 & 25000 & 26000 & 17000 & 16000 & 22000 & 7500 & 20000 & 26000 & 7400 & 5000 & 19000 \\
\hline $\mathrm{Ho}$ & $0.37 \mathrm{~L}$ & 1.5 & $0.08 \mathrm{~L}$ & 1.5 & $0.39 \mathrm{~L}$ & $0.1 \mathrm{~L}$ & $0.3 \mathrm{~L}$ & $0.1 \mathrm{~L}$ & $u$ & $0.37 \mathrm{~L}$ & 0.41 & 2.2 & 0.89 & 0.42 & 1.7 & 2.6 \\
\hline$k$ & 360 & 410 & 630 & 210 & 340 & 440 & 660 & 380 & 480 & 440 & 1500 & 460 & 410 & 200 & 650 & 620 \\
\hline$M_{0}$ & 3700 & 4500 & 4500 & 1800 & 2200 & 4500 & 4200 & 4000 & 2500 & 3800 & 3900 & 4000 & 7500 & 1800 & 2100 & 6100 \\
\hline$M n$ & 210 & 290 & 240 & 95 & 320 & 340 & 410 & 200 & 170 & 250 & 87 & 260 & 310 & 74 & 71 & 280 \\
\hline Ne & 750 & 1000 & 780 & 370 & 430 & 840 & 860 & 780 & 410 & 680 & 240 & 710 & 850 & 650 & 720 & 1300 \\
\hline $\mathrm{Ni}$ & 92 & 180 & 100 & 100 & 34 & 57 & 80 & 230 & 31 & 35 & 14 & 95 & 250 & 52 & 12 & 300 \\
\hline Po & 7 & 7.2 & 15 & 4.5 & 11 & 12 & 13 & 22 & 19 & 13 & 8 & 12 & 60 & 20 & 16 & 42 \\
\hline sb & $5.5 \mathrm{~L}$ & u & $u$ & $u$ & $\mathbf{u}$ & $u$ & u & $u$ & $u$ & $u$ & u & u & $u$ & $8.3 \mathrm{~L}$ & $u$ & u \\
\hline Sn & $u$ & 15 & u & $\mathbf{u}$ & $6.7 \mathrm{~L}$ & $u$ & $u$ & 6.6 & $5.9 \mathrm{~L}$ & $u$ & $u$ & $u$ & 5.7 & 10 & 0 & 6.8 \\
\hline$v$ & 59 & 76 & 54 & 27 & 34 & 55 & 48 & 46 & 48 & 71 & 18 & 50 & 61 & 20 & 20 & 49 \\
\hline $2 n$ & 52 & 85 & 62 & 33 & 33 & 58 & 49 & 74 & 41 & 46 & 16 & 56 & 93 & 27 & 6.7 & 88 \\
\hline
\end{tabular}




\begin{tabular}{|c|c|c|c|c|c|c|c|c|c|c|c|c|c|c|c|c|}
\hline \multicolumn{17}{|c|}{ TEST \&1 SOll WASHING RESULTS (25 $\mathrm{mm}$ to $2 \mathrm{~mm}$ (June 1993 Processing) (Sheet 2 of 2} \\
\hline & $807 C 14$ & B07C15 & $B 07 c 16$ & B07C17 & $B 07 C 18$ & Bo7c19 & BO7C20 & BO7C21 & BO7C22 & BO7C23 & BO7C24 & $B 07 C 25$ & $\mathrm{BO} \mathrm{OCA3}$ & lBo7c44 & $307 C 45$ & BO7C46 \\
\hline & $\mathrm{pC} / \mathrm{g}$ & $\mathrm{pC} / \mathrm{g}$ & $\mathrm{pC} i / \mathrm{g}$ & $\mathrm{pC} / \mathrm{g}$ & pCi/g & pci/g & $\mathrm{pCl} / \mathrm{g}$ & $\mathrm{pCl} / \mathrm{g}$ & $\mathrm{pC} / \mathrm{g}$ & $\mathrm{pCi} / \mathrm{g}$ & $\mathrm{pC} / \mathrm{g}$ & pCi/g & pCi/g & $\mathrm{pCi} / \mathrm{g}$ & $\mathrm{pCi} / \mathrm{g}$ & $\mathrm{pC} \mathrm{C} / \mathrm{g}$ \\
\hline${ }^{60} \mathrm{co}$ & $\begin{array}{r}0.0245 \\
X Y Z \\
\end{array}$ & $\begin{array}{r}0.013 \\
\text { xyz } \\
\end{array}$ & $\begin{array}{r}0.029 \\
X Y Z \\
\end{array}$ & $\begin{array}{r}0.031 \\
\text { XYZ } \\
\end{array}$ & $\begin{array}{r}0.032 \\
x y Z \\
\end{array}$ & $\begin{array}{r}0.003 \\
\text { XYZ } \\
\end{array}$ & $\begin{array}{r}0.035 \\
X Y 2 \\
\end{array}$ & $0 x y z$ & $0 \times y z$ & $\begin{array}{r}0.009 \\
X Y Z \\
\end{array}$ & $0 \mathrm{XYZ}$ & $\begin{array}{r}0.003 \\
\text { XYZ } \\
\end{array}$ & $\begin{array}{r}0.009 \\
\quad X Y Z \\
\end{array}$ & $\begin{array}{r}0.025 \\
\quad \mathrm{XYZ} \\
\end{array}$ & $\begin{array}{c}0.044 \\
\quad X Y Z \\
\end{array}$ & $\begin{array}{r}0.064 \\
X Y Z \\
\end{array}$ \\
\hline${ }^{137} \mathrm{cs}$ & $\begin{array}{r}0.0724 \\
X Y Z \\
\end{array}$ & $0.03 \mathrm{XYZ}$ & $\begin{array}{r}0.036 \\
X Y Z\end{array}$ & $\begin{array}{r}0.034 \\
X Y Z\end{array}$ & $\begin{array}{r}0.049 \\
X Y Z \\
\end{array}$ & $\begin{array}{r}0.039 \\
X Y Z\end{array}$ & $\begin{array}{r}0.057 \\
X Y Z\end{array}$ & $\begin{array}{r}0.082 \\
X Y Z \\
\end{array}$ & $\begin{array}{r}0.103 \\
X Y Z \\
\end{array}$ & $\begin{array}{r}0.056 \\
\mathrm{XYZ} \\
\end{array}$ & $\begin{array}{r}0.043 \\
X Y Z \\
\end{array}$ & $\begin{array}{r}0.034 \\
x y z \\
\end{array}$ & $\begin{array}{r}0.084 \\
\mathrm{XYZ} \\
\end{array}$ & $\begin{array}{r}0.106 \\
\mathrm{XYZ} \\
\end{array}$ & $\begin{array}{c}0.124 \\
\mathrm{XYZ} \\
\end{array}$ & $\begin{array}{r}0.059 \\
X Y Z \\
\end{array}$ \\
\hline $212 \mathrm{pt}$ & $\begin{array}{r}0.811 \\
X Y Z\end{array}$ & $\begin{array}{r}0.649 \\
X Y Z\end{array}$ & $\begin{array}{r}0.886 \\
X Y Z\end{array}$ & $\begin{array}{l}0.69 \\
X Y Z\end{array}$ & \begin{tabular}{r|}
0.824 \\
$X Y Z$
\end{tabular} & \begin{tabular}{l|}
0.83 \\
$X Y Z$
\end{tabular} & \begin{tabular}{r|}
0.687 \\
$X Y Z$
\end{tabular} & $\begin{array}{r}0.704 \\
X Y Z\end{array}$ & $\begin{array}{r}0.896 \\
X Y Z\end{array}$ & $\begin{array}{l}0.66 \\
X Y Z\end{array}$ & $\begin{array}{r}0.622 \\
X Y Z\end{array}$ & $\begin{array}{r}0.688 \\
X Y Z\end{array}$ & $\begin{array}{l}1.34 \\
X Y Z\end{array}$ & $\begin{array}{l}1.54 \\
X Y Z\end{array}$ & $\begin{array}{r}1.42 \\
X Y Z\end{array}$ & $\begin{array}{l}1.9 \mathrm{XYZ} \\
\mathrm{XYZXYZ}\end{array}$ \\
\hline $214_{\mathrm{pb}}$ & $\begin{array}{r}0.463 \\
\text { XYZ }\end{array}$ & $\begin{array}{r}0.497 \\
X Y Z\end{array}$ & $\begin{array}{r}0.403 \\
\text { XYZ }\end{array}$ & $\begin{array}{r}0.375 \\
X Y Z\end{array}$ & \begin{tabular}{|l|}
0.363 \\
$X Y Z$
\end{tabular} & \begin{tabular}{|c|}
0.521 \\
$X Y Z$
\end{tabular} & $\begin{array}{r}0.498 \\
X Y Z\end{array}$ & $\begin{array}{r}0.399 \\
X Y Z\end{array}$ & $\begin{array}{r}0.526 \\
X Y Z\end{array}$ & $\begin{array}{l}0.43 \\
X Y Z\end{array}$ & $\begin{array}{r}0.383 \\
\text { XYZ }\end{array}$ & $\begin{array}{r}0.465 \\
X Y Z \\
\end{array}$ & $\begin{array}{r}0.439 \\
\text { XYZ } \\
\end{array}$ & $\begin{array}{r}0.455 \\
X Y Z \\
\end{array}$ & $\begin{array}{r}0.443 \\
X Y Z \\
\end{array}$ & $\begin{array}{r}0.445 \\
X Y Z \\
\end{array}$ \\
\hline${ }^{224} \mathrm{Ra}$ & $\begin{array}{r}0.449 \\
X Y 2 \\
\end{array}$ & $\begin{array}{r}0.498 \\
x y z \\
\end{array}$ & $\begin{array}{r}0.358 \\
X Y Z \\
\end{array}$ & $\begin{array}{r}0.475 \\
x Y Z \\
\end{array}$ & $\begin{array}{r}0.426 \\
X Y Z \\
\end{array}$ & $\begin{array}{l}0.42 \\
X Y Z \\
\end{array}$ & $\begin{array}{l}0.55 \\
X Y z \\
\end{array}$ & $\begin{array}{r}0.344 \\
X Y Z \\
\end{array}$ & $\begin{array}{r}0.576 \\
\quad \mathrm{XYZ} \\
\end{array}$ & $\begin{array}{r}0.392 \\
\text { XYZ } \\
\end{array}$ & $\begin{array}{r}0.357 \\
\text { XYZ } \\
\end{array}$ & $\begin{array}{r}0.408 \\
X Y Z \\
\end{array}$ & $\begin{array}{r}0.459 \\
X Y Z \\
\end{array}$ & $\begin{array}{r}0.455 \\
\mathrm{XYZ} \\
\end{array}$ & $\begin{array}{r}1.45 \\
X Y Z \\
\end{array}$ & $\begin{array}{r}1.94 \\
X Y Z \\
\end{array}$ \\
\hline${ }^{226} \mathbf{R a}_{\mathrm{a}}$ & $\begin{array}{r}0.823 \\
X Y Z\end{array}$ & $\begin{array}{r}0.659 \\
x y z \\
\end{array}$ & $\begin{array}{r}0.899 \\
\text { XYZXYZ } \\
\end{array}$ & $0.7 \times r z$ & $\begin{array}{r}0.836 \\
X Y Z \\
\end{array}$ & $\begin{array}{r}0.843 \\
\text { XYZ } \\
\end{array}$ & $\begin{array}{r}0.698 \\
\mathrm{XYZ} \\
\end{array}$ & $\begin{array}{r}0.715 \\
\text { XYZ } \\
\end{array}$ & $\begin{array}{r}0.91 \\
X Y Z \\
\end{array}$ & $\begin{array}{r}0.67 \\
X Y Z \\
\end{array}$ & $\begin{array}{r}0.632 \\
\text { XYZ } \\
\end{array}$ & $\begin{array}{r}0.699 \\
\text { XYZ } \\
\end{array}$ & $\begin{array}{l}1.36 \\
X Y Z \\
\end{array}$ & $\begin{array}{r}1.57 \\
X Y Z \\
\end{array}$ & $\begin{array}{c}0.39 \\
X Y Z \\
\end{array}$ & $\begin{array}{l}0.46 \\
X Y Z \\
\end{array}$ \\
\hline $106_{\mathrm{Ru}}$ & $0 \mathrm{XYZ}$ & $0 \mathrm{xyz}$ & $0.08 \mathrm{XYZ}$ & $\begin{array}{r}0.164 \\
X Y Z\end{array}$ & oxyz & $0 \times r z$ & $\begin{array}{r}0.167 \\
X Y Z\end{array}$ & $\begin{array}{r}0.071 \\
X Y Z\end{array}$ & $\begin{array}{r}0.225 \\
X Y Z \\
\end{array}$ & $\begin{array}{r}0.061 \\
\text { XYZ }\end{array}$ & $0 \times y z$ & $0 x y z$ & $0 \times Y Z$ & $0 X Y Z$ & $\begin{array}{r}0 \\
x y z \\
\end{array}$ & oxyz \\
\hline $125 \mathrm{sb}$ & oxyz & oxyz & $0 \times Y Z$ & $0 \times Y z$ & $\begin{array}{r}0.027 \\
\mathrm{XYZ} \\
\end{array}$ & $0 \times y z$ & $\begin{array}{r}0.054 \\
\text { YYZ } \\
\end{array}$ & $0 \mathrm{xYz}$ & $0 \times Y z$ & oXYZ & oxyz & $\begin{array}{r}0.042 \\
\mathrm{XYZ} \\
\end{array}$ & $\begin{array}{r}0.028 \\
\mathrm{XYZ} \\
\end{array}$ & $0 \times Y Z$ & $\begin{array}{r}0 \\
x y z \\
\end{array}$ & $\begin{array}{r}0.027 \\
X Y Z \\
\end{array}$ \\
\hline & $\mathrm{pCl} / \mathrm{g}$ & $\mathrm{pCi} / \mathrm{a}$ & $\mathrm{pCl} / \mathrm{g}$ & pCi/g & $\mathrm{pCi} / \mathrm{g}$ & $\mathrm{pC} i / \mathrm{g}$ & $\mathrm{pC} / \mathrm{g}$ & pCi/g & pCi/g & $\mathrm{pC} / \mathrm{g}$ & $\mathrm{pCi} / \mathrm{g}$ & pCi/g & $\mathrm{pC} \mathrm{i} / \mathrm{g}$ & $\mathrm{pC}$ i/g & $p \mathrm{p} i / \mathrm{g}$ & $\mathrm{pC}$ Ci/g \\
\hline U (totall) & 527 & 64.2 & 1820 & 1420 & 3870 & 272 & 61.3 & 111 & 185 & 272 & 131 & 1200 & 509 & 540 & 188 & 1480 \\
\hline
\end{tabular}


DOE/RL-93-96, Rev. 0

\begin{tabular}{|c|c|c|c|c|c|c|c|c|c|c|c|c|}
\hline & & & & & ST \#1 $\underset{2 \mathrm{~mm}}{\mathrm{sol}}$ & $\begin{array}{l}\text { IL WAS } \\
\text { TO } 0\end{array}$ & $\begin{array}{l}G \text { RES } \\
\text { mm }\end{array}$ & & & & & \\
\hline & & & & & JUN & IE 1993 & PROCESSII & & & & & \\
\hline & $\begin{array}{r}\mathrm{BO7C26} \\
\text { soil } \\
\mathrm{mg} / \mathrm{kg}\end{array}$ & $\begin{array}{r}\mathrm{BO7C27} \\
\text { soil } \\
\mathrm{mg} / \mathrm{kg}\end{array}$ & $\begin{array}{r}\mathrm{BO7C28} \\
\text { soil } \\
\mathrm{mg} / \mathrm{kg}\end{array}$ & $\begin{array}{r}807 C 29 \\
\text { soil } \\
\mathrm{mg} / \mathrm{kg}\end{array}$ & \begin{tabular}{|r|}
$807 C 30$ \\
$80 i l$ \\
$\mathrm{mg} / \mathrm{kg}$
\end{tabular} & $\begin{array}{r}07 \mathrm{C3} \\
1 \\
s \text { oil } \\
\mathrm{mg} / \mathrm{kg}\end{array}$ & $\begin{array}{r}\mathrm{BO7C32} \\
\text { soil } \\
\mathrm{mg} / \mathrm{kg}\end{array}$ & $\begin{array}{r}807 C 68 \\
\text { soil } \\
\mathrm{mg} / \mathrm{kg}\end{array}$ & \begin{tabular}{|r|}
$807 C 55$ \\
$8 o i l$ \\
$\mathrm{mg} / \mathrm{kg}$
\end{tabular} & $\begin{array}{r}807 \mathrm{C5} 6 \\
\mathrm{soil} \\
\mathrm{mg} / \mathrm{kg}\end{array}$ & $\begin{array}{r}07 C 57 \\
\text { soil } \\
\mathrm{mg} / \mathrm{kg}\end{array}$ & $\begin{array}{r}\text { BO7C5\& } \\
\text { soil } \\
\mathrm{mg} / \mathrm{k} ;\end{array}$ \\
\hline$A_{0}$ & 10 & 12 & 9.2 & 12 & 9.7 & 11 & 10 & 11 & 11 & 14 & 12 & 12 \\
\hline$A 1$ & 17000 & 18000 & 13000 & 15000 & 14000 & 16000 & 14000 & 17000 & 17000 & 17000 & 16000 & 18000 \\
\hline$A=$ & 1.4 & 1.6 & 0.94 & 0.87 & 1.5 & 20 & 1.7 & 0.810 & 1.8 & 1.4 & 1.8 & 1.5 \\
\hline Ba & 300 & 340 & 360 & 460 & 280 & 370 & 380 & 330 & 470 & 470 & 570 & 480 \\
\hline 80 & $u$ & $u$ & $u$ & $u$ & $u$ & $u$ & $u$ & u & $u$ & 0.82 & $u$ & $u$ \\
\hline C. & 7000 & 7900 & 6200 & 8100 & 8500 & 8100 & 7100 & 8600 & 8400 & 10000 & 8300 & 9200 \\
\hline Cd & $0.47 \mathrm{~L}$ & $u$ & $u$ & $u$ & $u$ & $u$ & $u$ & $u$ & $0.48 \mathrm{~L}$ & $0.54 \mathrm{~L}$ & $0.43 \mathrm{~L}$ & $u$ \\
\hline Co & 6.6 & 5.9 & 5.9 & 7.6 & 6.1 & 6 & 6.9 & 7 & 5.9 & 7 & 6 & 5.5 \\
\hline$C_{r}$ & 120 & 120 & 97 & 140 & 99 & 110 & 110 & 110 & 130 & 160 & 130 & 140 \\
\hline$c_{u}$ & 1400 & 1400 & 1300 & 2200 & 1500 & 1600 & 1700 & 1700 & 2800 & 3200 & 2800 & 2700 \\
\hline$F_{0}$ & 18000 & 17000 & 17000 & 18000 & 18000 & 18000 & 18000 & 18000 & 16000 & 17000 & 15000 & 17000 \\
\hline$H_{0}$ & 1.1 & 0.97 & 0.83 & 0.78 & 0.96 & 0.96 & 9.4 & 1 & 1.1 & 1.8 & 1.4 & 1.8 \\
\hline$K$ & 720 & 790 & 660 & 690 & 760 & 850 & 690 & 870 & 700 & 750 & 780 & 800 \\
\hline$M_{0}$ & 5300 & 5000 & 4900 & 5500 & 5400 & 5300 & 5100 & 5500 & 5300 & 5900 & 5400 & 6100 \\
\hline$M n$ & 260 & 240 & 210 & 240 & 310 & 240 & 230 & 270 & 220 & 240 & 200 & 230 \\
\hline $\mathrm{Na}$ & 2000 & 1400 & 1000 & 1200 & 1200 & 1200 & 1100 & 1500 & 1200 & 1400 & 1300 & 1600 \\
\hline Ni & 150 & 160 & 130 & 200 & 150 & 150 & 170 & 160 & 210 & 230 & 200 & 210 \\
\hline$P_{0}$ & 28 & 31 & 29 & 30 & 27 & 29 & 29 & 32 & 36 & 44 & 38 & 42 \\
\hline sb & $u$ & $6.1 \mathrm{~L}$ & $u$ & $5.6 \mathrm{~L}$ & $u$ & $4.7 \mathrm{~L}$ & u & $u$ & $u$ & $6.1 \mathrm{~L}$ & $u$ & $u$ \\
\hline Sn & $8.6 \mathrm{~L}$ & 17 & $u$ & 19 & 12 & vo & 14 & $9.4 \mathrm{LQ}$ & 24 & 21 & 21 & 18 \\
\hline$v$ & 45 & 42 & 42 & 46 & 47 & 45 & 46 & 55 & 47 & 51 & 42 & 52 \\
\hline $2 n$ & 61 & 61 & 58 & 68 & 58 & 61 & 63 & 58 & 66 & 77 & 65 & 74 \\
\hline & $\mathrm{pCi} / \mathrm{a}$ & $\mathrm{pCC} / \mathrm{a}$ & $\mathrm{pCl} / \mathrm{g}$ & $\mathrm{pCl} / \mathrm{o}$ & $\mathrm{pCl} / \mathrm{g}$ & $\mathrm{pCS} / \mathrm{g}$ & $\mathrm{pCi} / \mathrm{g}$ & $\mathrm{pCl} / \mathrm{g}$ & $\mathrm{pCi} / \mathrm{g}$ & $\mathrm{pCl} / \mathrm{g}$ & $\mathrm{pCl} / \mathrm{a}$ & $\mathrm{pCl} / \mathrm{g}$ \\
\hline Co.60 & $\begin{array}{r}0.0359 \\
X Y Z\end{array}$ & $\begin{array}{r}0.0038 \\
X Y Z\end{array}$ & $\begin{array}{r}0.0167 \\
X Y Z\end{array}$ & $\begin{array}{r}0.0068 \\
X Y Z\end{array}$ & $\begin{array}{r}0.0311 \\
X Y Z\end{array}$ & $\begin{array}{l}0.05 \\
X Y Z\end{array}$ & $\begin{array}{r}0.0092 \\
X Y Z\end{array}$ & $\begin{array}{r}0.0277 \\
X Y Z\end{array}$ & $\begin{array}{r}0.0593 \\
X Y Z\end{array}$ & $\begin{array}{r}0.0409 \\
X Y Z\end{array}$ & $\begin{array}{r}0.0482 \\
X Y Z\end{array}$ & $\begin{array}{r}0.0704 \\
X Y Z\end{array}$ \\
\hline C8.137 & $0.107 \mathrm{XYZ}$ & $\begin{array}{r}0.102 \\
X Y Z \\
\end{array}$ & $\begin{array}{r}0.0861 \\
X Y Z\end{array}$ & $\begin{array}{r}0.102 \\
X Y Z \\
\end{array}$ & $\begin{array}{r}0.117 \\
X Y Z \\
\end{array}$ & $\begin{array}{r}0.0791 \\
X Y Z\end{array}$ & $\begin{array}{r}0.138 \\
X Y Z \\
\end{array}$ & $\begin{array}{r}0.0918 \\
X Y Z \\
\end{array}$ & $\begin{array}{r}0.0939 \\
X Y Z\end{array}$ & $\begin{array}{r}0.101 \\
X Y Z \\
\end{array}$ & $\begin{array}{r}0.133 \\
X Y Z \\
\end{array}$ & $\begin{array}{r}0.0977 \\
\quad X Y Z \\
\end{array}$ \\
\hline$P b-212$ & $|0.858 \times Y Z|$ & $\begin{array}{r}0.867 \\
X Y Z\end{array}$ & $\begin{array}{r}0.843 \\
X Y Z\end{array}$ & $\begin{array}{r}0.766 \\
X Y Z\end{array}$ & $\begin{array}{r}0.806 \\
X Y Z\end{array}$ & $\begin{array}{r}0.908 \\
X Y Z\end{array}$ & $\begin{array}{r}0.703 \\
X Y Z\end{array}$ & $\begin{array}{r}0.838 \\
X Y Z\end{array}$ & $1.5 \times Y Z$ & $\begin{array}{l}1.75 \\
X Y Z\end{array}$ & $1.22 \times Y Z$ & $1.45 \mathrm{XYZ}$ \\
\hline $\mathrm{Pb}-214$ & $0.494 \times Y Z \mid$ & $\begin{array}{r}0.389 \\
X Y Z\end{array}$ & $\begin{array}{r}0.328 \\
X Y Z\end{array}$ & $0.37 \mathrm{XYZ}$ & $\begin{array}{r}0.407 \\
X Y Z\end{array}$ & $\begin{array}{r}0.428 \\
X Y Z\end{array}$ & $\begin{array}{r}0.395 \\
X Y Z\end{array}$ & $\begin{array}{r}0.397 \\
X Y Z\end{array}$ & $0.4 \times Y Z$ & $\begin{array}{r}0.513 \\
X Y Z\end{array}$ & $\begin{array}{r}0.426 \\
X Y Z\end{array}$ & $\begin{array}{r}0.352 \\
X Y Z\end{array}$ \\
\hline Ae-224 & $0.341 \mathrm{XYZ}$ & $\begin{array}{r}0.385 \\
X Y Z\end{array}$ & $\begin{array}{r}0.384 \\
X Y Z\end{array}$ & $0.32 \times Y Z$ & $\begin{array}{r}0.539 \\
X Y Z\end{array}$ & $\begin{array}{r}0.415 \\
X Y Z\end{array}$ & $\begin{array}{r}0.254 \\
X Y Z\end{array}$ & $\begin{array}{r}0.854 \\
X Y Z\end{array}$ & $\begin{array}{l}1.53 \\
X Y Z\end{array}$ & $\begin{array}{l}1.78 \\
x y z\end{array}$ & $1.24 \mathrm{XYZ}$ & $1.47 \times Y Z$ \\
\hline Ae-226 & $0.872 \times Y Z$ & $\begin{array}{r}0.881 \\
X Y Z \\
\end{array}$ & $\begin{array}{r}0.857 \\
X Y Z \\
\end{array}$ & $\begin{array}{r}0.778 \\
X Y Z \\
\end{array}$ & $\begin{array}{r}0.82 \\
X Y Z \\
\end{array}$ & $\begin{array}{l}0.923 \\
0 \times Y Z\end{array}$ & $\begin{array}{r}0.716 \\
X Y Z \\
\end{array}$ & $\begin{array}{l}0.329 \\
\text { QXYZ }\end{array}$ & $\begin{array}{r}0.202 \\
X Y Z \\
\end{array}$ & $\begin{array}{r}0.441 \\
X Y Z\end{array}$ & $0.46 \mathrm{XYZ}$ & $\begin{array}{r}0.486 \\
X Y Z \\
\end{array}$ \\
\hline Au-106 & $0 \times Y Z$ & $0 \times Y Z$ & $\begin{array}{r}0.0438 \\
X Y Z\end{array}$ & $0 x y z$ & $0 X Y Z$ & $0 \times Y Z$ & $0 X Y Z$ & $\begin{array}{r}0.232 \\
X Y Z\end{array}$ & $0 X Y Z$ & $0 X Y Z$ & $0 X Y Z$ & $\begin{array}{r}0.354 \\
X Y Z\end{array}$ \\
\hline $5 b-125$ & $\begin{array}{r}0.0529 \\
\quad X Y Z \\
\end{array}$ & $\begin{array}{r}0.001 \\
X Y Z\end{array}$ & $0 X Y Z$ & $\begin{array}{r}0.0268 \\
X Y Z\end{array}$ & $0 X Y Z$ & $0 X Y Z$ & $0 X Y Z$ & $0 X Y Z$ & $0 \times y z$ & $\begin{array}{r}0.0521 \\
X Y Z\end{array}$ & $\begin{array}{r}0.113 \\
X Y Z\end{array}$ & $\begin{array}{r}0.0664 \\
X Y Z\end{array}$ \\
\hline & $\mathrm{pCl} / \mathrm{a}$ & $\mathrm{pCl} / \mathrm{a}$ & $\mathrm{pCi} / \mathrm{a}$ & $\mathrm{pCi} / \mathrm{o}$ & $\mathrm{pCl} / \mathrm{a}$ & $\mathrm{pCl} / \mathrm{q}$ & $\mathrm{pCl} / \mathrm{q}$ & $\mathrm{pCl} / \mathrm{g}$ & $\mathrm{pCl} / \mathrm{g}$ & $\mathrm{pCl} / \mathrm{g}$ & $\mathrm{pCl} / \mathrm{o}$ & $\mathrm{pCi} / \mathrm{o}$ \\
\hline U-Nat & 403 & 144 & 809 & 593 & 564 & 5160 & 362 & 3840 & 1100 & 614 & 848 & 1460 \\
\hline
\end{tabular}


DOE/RL-93-96, Rev. 0

\begin{tabular}{|c|c|c|c|c|c|c|c|}
\hline \multicolumn{8}{|c|}{$\begin{array}{l}\text { TEST \#1 SOIL WASHING RESULTS } \\
\text { MINUS } 0.425 \mathrm{~mm} \text { SLURRY WATER (UNFILTERED) } \\
\end{array}$} \\
\hline & \multicolumn{7}{|c|}{ JUNE 1993 PROCESSING } \\
\hline & $\begin{array}{r}807 \mathrm{C75} \\
\text { water } \\
\mathrm{mg} / \mathrm{L} \\
\end{array}$ & $\begin{array}{r}807 C 76 \\
\text { water } \\
\mathrm{mg} / \mathrm{L}\end{array}$ & $\begin{array}{r}\text { B07C77 } \\
\text { water } \\
\mathrm{mg} / \mathrm{L} \\
\end{array}$ & $\begin{array}{r}807 \mathrm{C85} \\
\text { water } \\
\mathrm{mg} / \mathrm{L} \\
\end{array}$ & $\begin{array}{r}\text { B07C79 } \\
\text { water } \\
\mathrm{mg} / \mathrm{L} \\
\end{array}$ & $\begin{array}{r}\text { B07C80 } \\
\text { water } \\
\mathrm{mg} / \mathrm{L} \\
\end{array}$ & $\begin{array}{r}\text { B07C81 } \\
\text { water } \\
\mathrm{mg} / \mathrm{L} \\
\end{array}$ \\
\hline $\mathrm{Ag}$ & 0.05 & 1 & 0.53 & 0.98 & 0.64 & 0.3 & 0.18 \\
\hline Al & 37 & 850 & 550 & 770 & 1000 & 480 & 250 \\
\hline As & $0.003 L$ & 0.024 & 0.028 & 0.026 & 0.023 & 0.022 & 0.011 \\
\hline$B a$ & 2.1 & 670 & 43 & 600 & 120 & 59 & 27 \\
\hline $\mathrm{Be}$ & $0.0013 \mathrm{~L}$ & 0.019 & 0.011 & 0.018 & 0.018 & 0.0082 & 0.0042 \\
\hline $\mathrm{Ca}$ & 19 & 400 & 170 & 400 & 350 & 170 & 100 \\
\hline Cd & $\underline{u}$ & 0.011 & $u$ & $0.0091 L$ & $u$ & $\underline{u}$ & $u$ \\
\hline Co & $0.0071 \mathrm{~L}$ & 0.095 & 0.14 & 0.092 & 0.27 & 0.13 & 0.066 \\
\hline Cr & 0.38 & 9.2 & 5.5 & 8.6 & 9.5 & 4.6 & 2.6 \\
\hline cu & 3.5 & 100 & 50 & 98 & 60 & 29 & 25 \\
\hline Fe & 13 & 230 & 160 & 220 & 270 & 130 & 63 \\
\hline $\mathrm{Hg}$ & 0.0045 & 0.13 & 0.078 & 0.14 & 0.12 & 0.096 & 0.049 \\
\hline$\underline{k}$ & 3.5 & 34 & 24 & 33 & 37 & 18 & 9.2 \\
\hline$m g$ & 10 & 190 & 120 & 170 & 210 & 100 & 59 \\
\hline Mn & 0.27 & 5.3 & 3.7 & 4.9 & 6 & 2.9 & 1.6 \\
\hline $\mathrm{Ma}$ & 31 & 120 & 110 & 120 & .170 & 96 & 66 \\
\hline $\mathrm{Mi}$ & 0.32 & 10 & 5 & 9.6 & 5.3 & 2.7 & 2 \\
\hline$p b$ & 0.093 & 2.6 & 1.1 & 2.1 & 2.1 & 0.98 & 0.55 \\
\hline sb & $u$ & $u$ & $u$ & $u$ & $u$ & $u$ & $\mathbf{u}$ \\
\hline sn & $0.061 L$ & 1 & 0.68 & 0.89 & 1.3 & 0.67 & 0.38 \\
\hline$v$ & $0.0089 \perp$ & 0.36 & 0.22 & 0.36 & 0.4 & 0.19 & 0.097 \\
\hline $2 n$ & 0.11 & 2.6 & 1.7 & 2.4 & 3 & 1.5 & 0.89 \\
\hline & pic/L & $\mathrm{pCi} / \mathrm{L}$ & $\mathrm{pCi} / \mathrm{L}$ & $\mathrm{PCi} / \mathrm{L}$ & $\mathrm{pCi} / \mathrm{L}$ & $\mathrm{pCi} / \mathrm{L}$ & $\mathrm{pCi} / \mathrm{L}$ \\
\hline$C 0-60$ & 0 & 2.19 & $11.9 \times Y Z$ & 0.877 & $0 x y z$ & $18.6 X Y Z$ & $0 x y z$ \\
\hline Cs-137 & 1.32 & 0.0867 & $9.56 \times Y Z$ & 5.47 & $4.86 \times Y Z$ & $7.43 \times Y Z$ & $25.1 \times Y Z$ \\
\hline \multicolumn{8}{|l|}{$\mathrm{Pb}-212$} \\
\hline \multicolumn{8}{|l|}{$\mathrm{Pb}-214$} \\
\hline \multicolumn{8}{|l|}{ Ra-224 } \\
\hline \multicolumn{8}{|l|}{ Ra-226 } \\
\hline Ru- 106 & 23.3 & 47.9 & $0 X Y Z$ & 0 & $0 X Y Z$ & $80.8 \times Y Z$ & $0 X Y Z$ \\
\hline \multirow[t]{2}{*}{$S b-125$} & 0 & 0 & $42.3 \times Y 2$ & 0 & $27.7 \times Y 2$ & $0 x y z$ & $30.2 \times Y 2$ \\
\hline & $49 / 2$ & $49 / 2$ & ug/L & 49/2 & $u g / L$ & U9/L & uq/2 \\
\hline U-Nat & 10200 & 24800 & 58000 & 30600 & 93700 & 38500 & 23400 \\
\hline
\end{tabular}

B. 1-9 
DOE/RL-93-96, Rev. 0

\begin{tabular}{|c|c|c|c|c|c|c|c|}
\hline & & & $\begin{array}{l}\text { \#1 SOIL WA } \\
\text { UUS } 0.425 \mathrm{~mm}\end{array}$ & $\begin{array}{l}\text { IING RESULTS } \\
\text { URRY SOILS } \\
\end{array}$ & & & \\
\hline & & & JUNE & 993 PROCESSI & G & & \\
\hline & $\begin{array}{r}\text { Bo7c91 } \\
\text { soil } \\
\mathrm{mg} / \mathrm{kg} \\
\end{array}$ & $\begin{array}{r}\mathrm{B} 07 \mathrm{Cg} 2 \\
\mathrm{soil} \\
\mathrm{mg} / \mathrm{kg}\end{array}$ & $\begin{array}{r}\mathrm{B} 07 \mathrm{cg3} \\
\mathrm{soil} \\
\mathrm{mg} / \mathrm{kg}\end{array}$ & $\begin{array}{r}807 c 95 \\
\mathrm{soil} \\
\mathrm{mg} / \mathrm{kg}\end{array}$ & $\begin{array}{r}\mathrm{B} 07 \mathrm{Cg} \\
\mathrm{soil} \\
\mathrm{mg} / \mathrm{kg} \\
\end{array}$ & $\begin{array}{r}\mathrm{B} 07 \mathrm{Cg} \\
\mathrm{soil} \\
\mathrm{mg} / \mathrm{kg}\end{array}$ & $\begin{array}{r}\mathrm{B} 07 \mathrm{CB} 1 \\
\mathrm{soil} \\
\mathrm{mg} / \mathrm{kg} \\
\end{array}$ \\
\hline $\mathrm{Ag}$ & 2.1 & $1.5 \mathrm{~L}$ & $1.1 \mathrm{~L}$ & 2.2 & $1.5 \mathrm{~L}$ & 2.8 & $1.9 \mathrm{~L}$ \\
\hline 11 & 7600 & 7800 & 7100 & 8900 & 10000 & $9900 \propto$ & 69000 \\
\hline As & 1.3 & 1.2 & 1.2 & 2.2 & 1.1 & 1.70 & 10 \\
\hline 30 & 220 & 200 & 190 & 310 & 380 & 390 a & 3000 \\
\hline $3 e$ & 0.261 & 0.231 & 0.186 & 0.11 & $0.22 L$ & 0.21 & 0.216 \\
\hline $\mathrm{Ea}$ & 3900 & 4000 & 3800 & 5100 & 5000 & $5400 a$ & 41000 \\
\hline $\mathrm{cd}$ & u & $u$ & $\underline{u}$ & $\underline{U}$ & $u$ & $\underline{U}$ & $u$ \\
\hline Co & 3.6 & 4.6 & 4.9 & 6 & 4.7 & 5.3 & 5 \\
\hline $\mathrm{Er}$ & 34 & 30 & 28 & 45 & 44 & 530 & 400 \\
\hline $\mathrm{Cu}$ & 320 & 240 & 150 & 420 & 420 & $500 a$ & 2600 \\
\hline fe & 12000 & 13000 & 15000 & 19000 & 14000 & 15000 & 14000 \\
\hline Hg & $0.3 \mathrm{~L}$ & $0.2 L$ & $0.35 \mathrm{~L}$ & 0.49 & $0.3 \mathrm{~L}$ & 0.48 & 0.54 \\
\hline$x$ & 670 & 750 & 730 & 800 & 810 & 790 & 650 \\
\hline Mg & 3100 & 3100 & 3300 & 3800 & 3700 & 3700 & 3200 \\
\hline Yn & 160 & 180 & 200 & 220 & 180 & 180 & 170 \\
\hline $\mathrm{Na}$ & 540 & 650 & 650 & 710 & 890 & 9000 & 6200 \\
\hline yi & 34 & 27 & 22 & 40 & 30 & 470 & 290 \\
\hline $\mathrm{pb}$ & 13 & 13 & 11 & 16 & 15 & 240 & 170 \\
\hline$s b$ & $\underline{u}$ & $u$ & $4.4 \mathrm{~L}$ & $\underline{u}$ & $\underline{U}$ & 4.51 & $u$ \\
\hline sn & $U$ & 64 & $\underline{U}$ & u & $6.1 \mathrm{~L}$ & $u$ & $u$ \\
\hline$v$ & 37 & 38 & 48 & 61 & 42 & 45 & 39 \\
\hline $\mathrm{Zn}$ & 35 & 36 & 37 & 44 & 42 & 44 & 39 \\
\hline & $\mathrm{pci} / \mathrm{g}$ & $\mathrm{pci} / \mathrm{g}$ & $\mathrm{pci} / \mathrm{g}$ & $\mathrm{pci} / \mathrm{g}$ & $\mathrm{pci} / \mathrm{g}$ & $\mathrm{PCi} / \mathrm{g}$ & $\mathrm{pCi} / \mathrm{g}$ \\
\hline co-60 & $0 X Y Z$ & $0 X Y Z$ & $0 \times Y 2$ & $0 X Y Z$ & $0.0099 \times Y Z$ & $0.0074 \times Y 2$ & $0.0077 \times Y Z$ \\
\hline Cs-137 & $0.152 X Y Z$ & $0.118 \times Y Z$ & $0.138 \times Y 2$ & $0.174 \mathrm{XYZ}$ & $0.279 \times Y Z$ & $0.303 \times Y 2$ & $0.224 \times Y Z$ \\
\hline $\mathrm{pb}-212$ & $0.596 \times Y Z$ & $0.604 \times Y Z$ & $0.834 \times Y Z$ & $0.828 \times Y Z$ & $0.724 \times Y Z$ & $0.821 \times Y Z$ & $0.917 \times Y Z$ \\
\hline$p b-214$ & $0.511 \times Y Z$ & $0.403 \times Y Z$ & $0.556 \times Y Z$ & $0.424 \times Y Z$ & $0.518 \times Y Z$ & $0.478 \times Y Z$ & $0.619 \times Y Z$ \\
\hline $\mathrm{Ba}-224$ & $0.608 \times Y Z$ & $0.616 \times Y Z$ & $0.85 \times Y Z$ & $0.84 \times Y Z$ & $0.734 \times Y Z$ & $0.832 \times Y Z$ & $0.55 \times Y Z$ \\
\hline $20-2226$ & $0.461 \mathrm{XYZ}$ & $0.459 \times Y Z$ & $0.534 \times Y 2$ & $0.448 \times Y 2$ & $0.458 \times Y Z$ & $0.509 \times Y Z$ & $0.929 \times Y Z$ \\
\hline zu-106 & $0.0369 \times Y Z$ & $0.209 \times Y Z$ & $0.0328 \times Y Z$ & $0.0307 \times Y Z$ & $0 X Y Z$ & $0.4466 \times Y 2$ & $0.0867 \times Y Z$ \\
\hline $5 b-125$ & $0.0251 \times Y Z$ & $0.0062 \times Y Z$ & $0.0726 \times Y Z$ & $0.0429 \times Y Z$ & $0.0428 \times Y Z$ & $0 X Y Z$ & $0 X Y Z$ \\
\hline & $\mathrm{Pci} / \mathrm{a}$ & $\mathrm{pci} / \mathrm{g}$ & $\mathrm{PCi} / \mathrm{a}$ & $\mathrm{pci} / \mathrm{g}$ & $\mathrm{PCi} / \mathrm{g}$ & $\mathrm{PCi} / \mathrm{g}$ & $\mathrm{PCi} / \mathrm{g}$ \\
\hline$y$-Mat & 217 & 214 & 158 & 173 & 358 & $355 \square$ & 8270 \\
\hline
\end{tabular}


DOE/RL-93-96, Rev. 0

\begin{tabular}{|c|c|c|c|c|c|c|c|c|c|c|c|c|}
\hline & \multicolumn{5}{|c|}{ FRESH WATER (UNF ILTERED) } & \multicolumn{7}{|c|}{ MINUS $0.425 \mathrm{~mm}$ SLURRY WATER (UNFILTERED) } \\
\hline & \multicolumn{5}{|c|}{ JUNE 1993 PROCESSING } & \multicolumn{7}{|c|}{ JUNE 1993 PROCESSING } \\
\hline & $\begin{array}{r}\text { B07C70 } \\
\text { water } \\
\mathrm{mg} / \mathrm{L}\end{array}$ & $\begin{array}{r}\text { B07C71 } \\
\text { water } \\
\mathrm{mg} / \mathrm{h}\end{array}$ & $\begin{array}{r}807 \mathrm{C72} \\
\text { water } \\
\mathrm{mo} / \mathrm{L}\end{array}$ & $\begin{array}{r}807 C 73 \\
\text { trp blk } \\
\mathrm{mg} / \mathrm{L}\end{array}$ & $\begin{array}{r}\text { B07C74 } \\
\text { trp b/k } \\
\mathrm{mg} / \mathrm{L}\end{array}$ & $\begin{array}{r}\mathrm{B07C75} \\
\text { water } \\
\mathrm{mg} / \mathrm{L}\end{array}$ & $\begin{array}{r}\mathrm{B07C76} \\
\text { water } \\
\mathrm{mg} / \mathrm{L}\end{array}$ & $\begin{array}{r}\mathrm{B07C77} \\
\text { water } \\
\mathrm{mg} / \mathrm{L}\end{array}$ & $\begin{array}{r}\text { B07C85 } \\
\text { water } \\
\mathrm{mg} / \mathrm{L}\end{array}$ & $\begin{array}{r}\text { B07C79 } \\
\text { water } \\
\mathrm{mg} / \mathrm{L}\end{array}$ & $\begin{array}{r}\text { B07C80 } \\
\text { water } \\
\mathrm{mg} / \mathrm{L}\end{array}$ & $\begin{array}{r}\text { B07C81 } \\
\text { water } \\
\mathrm{mg} / \mathrm{L}\end{array}$ \\
\hline Chloroform & 0.05 & $0.02 \mathrm{OH}$ & 0.020 & $u$ & $u$ & 0.01 & 0.01 & $0.01 \mathrm{H}$ & 0.01 & $\begin{array}{r}0.0029 \\
H\end{array}$ & $\begin{array}{r}0.0044 \\
H\end{array}$ & $\begin{array}{r}0.0064 \\
H\end{array}$ \\
\hline Mathyl Ethyl Kotono & $u$ & UH & $u$ & $u$ & $u$ & 0.07 & $u$ & $0.05 \mathrm{H}$ & $u$ & $0.18 \mathrm{H}$ & $0.03 \mathrm{H}$ & $0.02 \mathrm{H}$ \\
\hline Totrachloroethylene & $u$ & UH & u & $u$ & u & 0.001 & 0.0013 & $\begin{array}{r}0.0018 \\
H\end{array}$ & 0.0016 & $\begin{array}{r}0.0023 \\
H\end{array}$ & $\begin{array}{r}0.0025 \\
H\end{array}$ & $\begin{array}{r}0.0038 \\
H\end{array}$ \\
\hline Totrahydrofuran & $u$ & UH & $u$ & $u$ & u & $u$ & $u$ & UH & $u$ & $0.08 \mathrm{H}$ & UH & UH \\
\hline Trichloroethylene & $u$ & UH & $u$ & $u$ & $u$ & 0.0034 & 0.0054 & $\begin{array}{r}0.0064 \\
H\end{array}$ & 0.0067 & $\begin{array}{r}0.0077 \\
H\end{array}$ & $\begin{array}{r}0.0097 \\
H\end{array}$ & $0.01 \mathrm{H}$ \\
\hline 1.2-Dichloroethane. d4 & 0.05 & $0.04 \mathrm{H}$ & 0.05 & 0.05 & 0.06 & 0.05 & 0.06 & $0.05 \mathrm{H}$ & 0.06 & $0.04 \mathrm{H}$ & $0.04 \mathrm{H}$ & $0.05 \mathrm{H}$ \\
\hline Toluene, d8 & 0.05 & $0.05 \mathrm{H}$ & 0.05 & 0.05 & 0.05 & 0.05 & 0.05 & $0.05 \mathrm{H}$ & 0.05 & $0.05 \mathrm{H}$ & $0.06 \mathrm{H}$ & $0.05 \mathrm{H}$ \\
\hline 4-Bromofiuorobenzene & 0.05 & $0.06 \mathrm{H}$ & 0.05 & 0.05 & 0.05 & 0.05 & 0.05 & $0.05 \mathrm{H}$ & 0.05 & $0.05 \mathrm{H}$ & $0.06 \mathrm{H}$ & $0.05 \mathrm{H}$ \\
\hline
\end{tabular}

U=Analyzed for but undetected

$Q=0$ ata can be used qualitatively

$H=H o l d i n g$ time missed 
Sample Matrix (soil/water): HATER

Leachace vol analyzed (mL): 1.0 Date Received: $06 / 30 / 93$ oate Analyzed: $07 / 12 / 93$. Instrument 10: 4500
Lab File 10: 30712R0S

TCLP Exeraction Date: $07 / 09 / 93$ Date Leachate Extracted:

Dilution factor: 5.0

\begin{tabular}{|c|c|c|c|}
\hline CAS NO. & COMPOUND & $\begin{array}{l}\text { RESULT } \\
\text { (mg/L) }\end{array}$ & $\begin{array}{c}P Q L \\
(m g / L)\end{array}$ \\
\hline $79 \cdot 63 \cdot 2$ & Benzene & ND & 0.025 \\
\hline $56 \cdot 23 \cdot 5$ & Carbon Tetrachloride & NO & 0.025 \\
\hline $108 \cdot 90 \cdot 7$ & - chlorobenzene & no & 0.025 \\
\hline $67 \cdot 66 \cdot 3$ & chloroform & 0.014 & 0.025 \\
\hline $107 \cdot 06 \cdot 2$ & 1,2-0ichloroethene & NO & 0.025 \\
\hline $75 \cdot 35 \cdot 4$ & 1,1-oichloroethylene & no & 0.025 \\
\hline $78-93-3$ & Hethyl Ethyl Retone & NO & 0.05 \\
\hline $127 \cdot 18-4$ & Tetrechloroethylene & No & 0.025 \\
\hline $79.01 \cdot 6$ & Trienloreethylene & NO & 0.025 \\
\hline $75 \cdot 01 \cdot 4$ & vinyl chloride & no & 0.05 \\
\hline
\end{tabular}

* recovery surrogate compouno

\begin{tabular}{|c|c|}
\hline d8-Tolvene & 107 \\
\hline Bromof luorobenzene & 106 \\
\hline 1,2-0 ichloroethene-dh & 107 \\
\hline
\end{tabular}

B. 1-12 


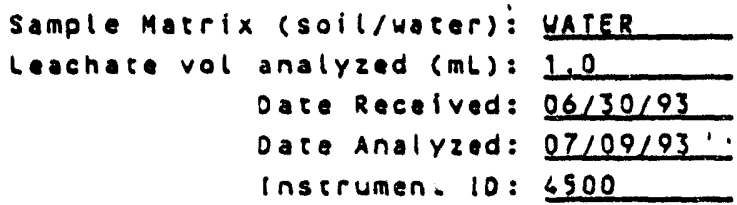

\begin{tabular}{|c|c|c|c|}
\hline CAS NO. & COMPOUHD & $\begin{array}{l}\text { RESULT } \\
(\mathrm{mg} / \mathrm{L})\end{array}$ & $\begin{array}{c}P O L \\
(m g / L)\end{array}$ \\
\hline $71 \cdot 43 \cdot 2$ & Benzene & NO & 0.025 \\
\hline $56 \cdot 23 \cdot 5$ & carbon retrachloride & NO & 0.025 \\
\hline $108 \cdot 90 \cdot 7$ & - chlorobenzene & NO & 0.025 \\
\hline $67 \cdot 66 \cdot 3$ & Chloroform & 0.006 & 0.025 \\
\hline $107 \cdot 06 \cdot 2$ & $1.2 \cdot 0$ tchloroethane & MD & 0.025 \\
\hline $75 \cdot 35 \cdot 4$ & 1,1-olehloroethylene & ND & 0.025 \\
\hline $78-93-3$ & Nethyl Ethyl Ketone & NO & 0.05 \\
\hline $127 \cdot 18 \cdot 6$ & Tetrachloroethylene & no & 0.025 \\
\hline 79.01 .6 & Iplehloroethylene & ND & 0.025 \\
\hline $75 \cdot 01 \cdot 4$ & vinyl chloride & NO & 0.05 \\
\hline
\end{tabular}

* recovert surrogate compound

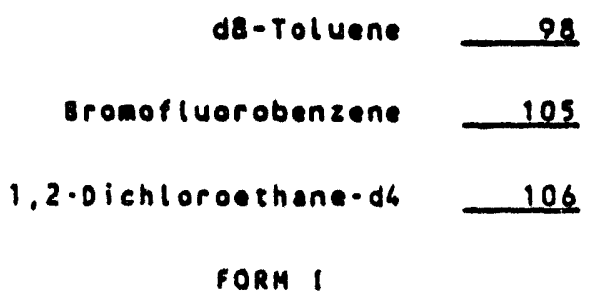




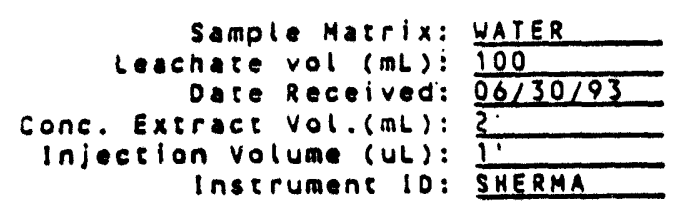

Lab file 10:30720s16 TClP Extraction dace: $\frac{07107 / 93}{07 / 06 / 93}$ Dace Leachate Extracted: 07/08/93 oate Analyzed: 07/20/93 conc. Extract Vol. ( $\mathrm{mL}$ ): instrumene 10: SHERMA oliution ractor:

\begin{tabular}{|c|c|c|c|}
\hline CAS NO. & COMPOUHO & $\begin{array}{l}\text { RESULT } \\
(m g / L)\end{array}$ & $\begin{array}{c}P Q L \\
(m g / L)\end{array}$ \\
\hline $1319 \cdot 77 \cdot 3$ & Cresol (rotal) & ND & 0.1 \\
\hline $87 \cdot 86 \cdot 5$ & Pencachlorophenol & NO & 0.5 \\
\hline $95 \cdot 95 \cdot 4$ & $2,4,5$ - Trichlorophenol & NO & 0.1 \\
\hline $88 \cdot 06 \cdot 2$ & $2,4,6 \cdot$ iriehlorophenol & NO & 0.1 \\
\hline $106-46 \cdot 7$ & 1.4-0ichlorobenzene & NO & 0.1 \\
\hline $121 \cdot 14 \cdot 2$ & 2.6-oinitrotoluene & NO & 0.1 \\
\hline $118-74-1$ & Hexechl orobenzene & NO & 0.1 \\
\hline $87-68-3$ & Hexechlor obueadiene & ND & 0.1 \\
\hline $67 \cdot 72 \cdot 1$ & Hexech loroethene & ND & 0.1 \\
\hline $98 \cdot 95 \cdot 3$ & Ni erobenzene & NO & 0.1 \\
\hline $110-86 \cdot 1$ & Pyridine & NO & 0.2 \\
\hline
\end{tabular}

* recover surrogate compound 2-fl vorophenol Phenol-os

2,4,6-Tribromophenol Nierobenzene-ds 2-Pluorobiphenyl Terphenyl-dis

$\begin{array}{r}94 \\ \hline 99 \\ \hline \frac{93}{95} \\ \hline \frac{84}{90} \\ \hline\end{array}$


DOE/RL-93-96, Rev. 0

Tha Inc.
000112

vork order $13-06-092$ eceived: $06 / 30 / 93$
FRACTION 02B TEST COOE TC- 1 oate \& Time collected $06 / 26 / 93$
NAME ICLP SeEi-Volatiles fore 1 Category

\section{ICLP SEMI-VOLATILE ORGANICS}

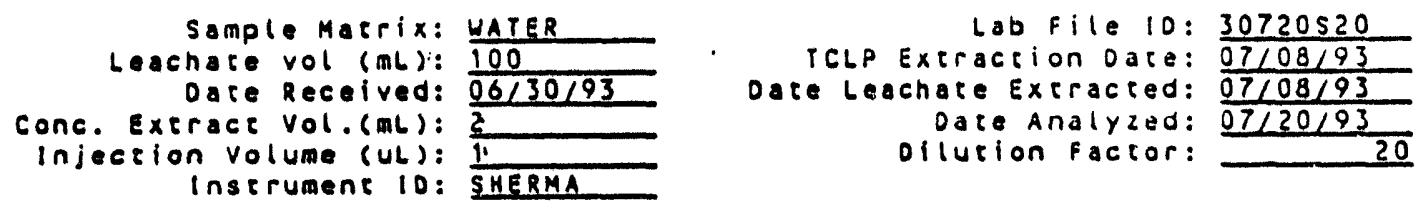

\begin{tabular}{|c|c|c|c|}
\hline CAS HO. & COMPOUND & $\begin{array}{l}\text { RESULY } \\
\text { (mg/L) }\end{array}$ & $\begin{array}{c}P O L \\
(m g / L)\end{array}$ \\
\hline $1319 \cdot 77 \cdot 3$ & Crosol (Total) & ND & 0.1 \\
\hline $87 \cdot 25 \cdot 5$ & Pentechlorophenol & NO & 0.5 \\
\hline $95 \cdot 95 \cdot 4$ & $2,6,5 \cdot$ irleh lorophenol & ND & 0.1 \\
\hline $88 \cdot 06 \cdot 2$ & $2,6,6$ - irich lorophenol & ND & 0.1 \\
\hline $106-46-7$ & 1.4-0ichlorobenzene & ND & 0.1 \\
\hline $121 \cdot 16 \cdot 2$ & $2.6-0 \mathrm{inl}$ trotoluene & ND & 0.1 \\
\hline $118 \cdot 76 \cdot 1$ & Hexachlorobenzene & nO & 0.1 \\
\hline $87 \cdot 68 \cdot 3$ & Hexachlorobutadiene & NO & 0.1 \\
\hline $67 \cdot 72 \cdot 1$ & Hexech loroechane & ND & 0.1 \\
\hline $98 \cdot 95 \cdot 3$ & . Nitrobenzene & NO & 0.1 \\
\hline $110-86-1$ & Pyridine & NO & 0.2 \\
\hline
\end{tabular}

* recover surrogate compound

2- Fluorophenol

Phenol-d5

$2,6,6-$ ir ibromophenol

Ni crobenzene.ds

2-Fluorobipheny

Terphenyl.d14

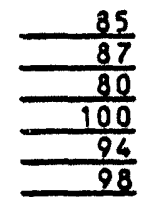

Fonn 1 
DOE/RL-93-96, ReV. $0 \quad \cup \cup \cup \perp \cup-$

REPORT TRA InC. Hesules by Sample
Rork Order 13.06 .092
eired: $06 / 30 / 93$
PLE 10 B08ML6
FRACTION OZB TEST CODE TCPI
NAME TCLP pesticides ford 1
Dore 8 rime collecied 06,24/93 Category

ICLP CHLORINATEO PESTICIOES

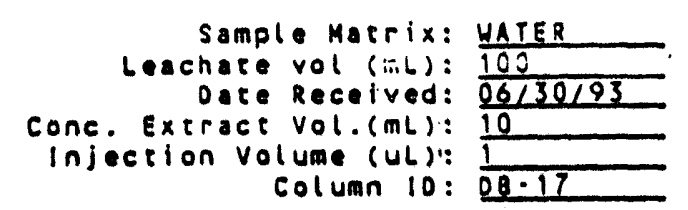

Lab Fille 10: AG12028

TCLP Extraction Date: $\frac{07 / 08 / 93}{07 / 08 / 93}$ Date leachate Extracted: $\frac{07 / 08 / 93}{07 / 13 / 93}$

Date Analyzed: $07 / 13 / 93$

oilution factor:

Column 10:

\begin{tabular}{|c|c|c|c|}
\hline CAS NO. & COMPOUND & $\begin{array}{l}\text { RESULT } \\
(m g / L)\end{array}$ & $\begin{array}{c}P Q L \\
(m g / L)\end{array}$ \\
\hline $57 \cdot 74 \cdot 9$ & chlordane & NO & 0.005 \\
\hline $72 \cdot 20-8$ & Endrin & ND & 0.001 \\
\hline $76 \cdot 46 \cdot 8$ & Heptechlor & ND & 0.0005 \\
\hline $1024 \cdot 57 \cdot 3$ & Heptechlor Epoxide & ND & 0.0005 \\
\hline $58 \cdot 89 \cdot 9$ & Lindane & ND & 0.0005 \\
\hline $72 \cdot 43 \cdot 5$ & Methoxychlor & ND & 0.005 \\
\hline $8001 \cdot 35 \cdot 2$ & Toxaphene & ND & 0.020 \\
\hline
\end{tabular}

* recovery surrogate compound

$\begin{array}{rr}r e x & 83 \\ 0 C 8 & 77\end{array}$

FORM 1 
DOE/RL-93-96, Rev. 0

TMa Ine.
UUU18Y

work order 13.06 .092 eired: $06 / 30 / 93$

0 Bosmro
FRACTION OIC TEST COOE TCPI

oate rime collocied $06 / 26 / 93$

NAME TCLP Pesticides form 1

ICLP CHLORINATED PESTICIOES

Sampl- Marrix: HATER

Leachate rol (mL): 100

Dere Recaived: $\frac{06 / 30 / 93}{10}$

Conc. Extract Vol. (mL): 10

injection volume (UL): 1

column 10:
Lab file 10: AC12025

rCLP Extraction Dare: $\frac{07}{0707 / 93}$ Dete Leachate Extracted: $\frac{07 / 08 / 93}{07 / 12 / 93}$ oace Analyzed: $07 / 12 / 93$

oilucion factor:

1.

\begin{tabular}{|c|c|c|c|}
\hline CAS NO. & COMPOUND & $\begin{array}{l}\text { RESULT } \\
(\mathrm{mg} / \mathrm{L})\end{array}$ & $\begin{array}{c}P Q L \\
(m g / L)\end{array}$ \\
\hline $57 \cdot 74 \cdot 9$ & chlordane & No & 0.005 \\
\hline $72 \cdot 20 \cdot 8$ & Endrin & No & 0.001 \\
\hline $76 \cdot 44 \cdot 8$ & Heptachlor & NO & 0.0005 \\
\hline $1026 \cdot 57 \cdot 3$ & Heptachlor Epoxide & NO & 0.0005 \\
\hline $58 \cdot 89 \cdot 9$ & Lindane & NO & 0.0005 \\
\hline $72-43-5$ & Hethoxychlor & NO & .0 .005 \\
\hline $8001-35-2$ & Poxaphene & ND & 0.020 \\
\hline
\end{tabular}

x recovery surrogate compouno

$r \bar{C}^{-}$
OCB -85

FORM 1 
DOE/RL-93-96, Rev. 0

THA Inc. Rosults by samplert FRACTION 02B TEST COOE TCHI oute \& rime collected $06 / 24 / 93$
UU113/1

Work order 13.06 .092 category

\section{ICLP CHLORINATEO HERBICIOES}
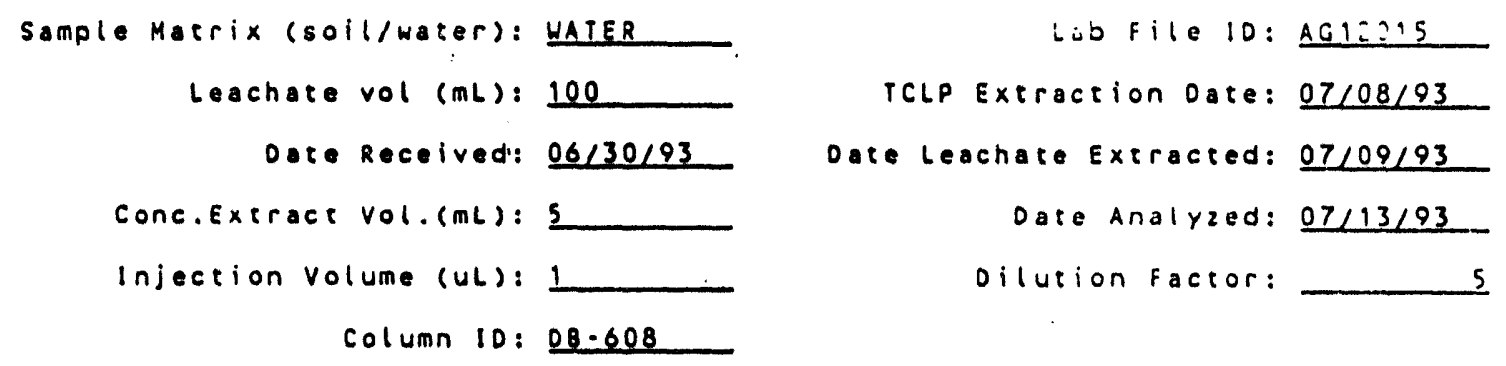

\begin{tabular}{|r|r|r|r|}
\hline CAS NO. & COMPOUND & $\begin{array}{c}\text { RESULT } \\
(\mathrm{mg} / \mathrm{L})\end{array}$ & $\begin{array}{r}\text { PQL } \\
(\mathrm{mg} / \mathrm{L})\end{array}$ \\
\hline $94 \cdot 75 \cdot 7$ & $2,4 \cdot 0$ & NO & 0.010 \\
\hline $93 \cdot 72 \cdot 1$ & $2,4.5 \cdot T P$ & ND & 0.0010 \\
\hline
\end{tabular}

x recovert surrogate compouno

D. DCAA 105

FORM 1 
DOE/RL-93-96, Rev. 0

eceired: $06 / 30 / 93$

TMa Ine.

REPORT

Results by sample

work order $13-06-092$

AMPLE 10 BOBHMO

FRACTION OIC TEST CODE TCMI

ICLP Metals fore:

ICLP METALS

Sampl - Matrix: HATER

TCLP Extraction Date: $08 / 23 / 93$

Date Received: $06 / 30 / 93$

\begin{tabular}{|c|c|c|c|c|}
\hline Cas no. & COMPOUNO & $\begin{array}{l}\text { RESULT } \\
(\mathrm{mg} / \mathrm{L})\end{array}$ & $\begin{array}{c}P Q L \\
(m g / L)\end{array}$ & METHOD \\
\hline $7440-38 \cdot 2$ & Arsente & 0.006 & 0.001 & F \\
\hline $7640 \cdot 39-3$ & Bariun & 3.69 & 0.001 & $p$ \\
\hline $7440-43-9$ & Codmiun & NO & 0.007 & $p$ \\
\hline $7440-47-3$ & Chromiun & 0.078 & 0.006 & $p$ \\
\hline $7439-92 \cdot 1$ & Lesd & 0.017 & 0.001 & $F$ \\
\hline 7439.97 .6 & Mercury & 0.0012 & 0.0002 & ev \\
\hline $7782 \cdot 69-2$ & seleniun & 0.011 & 0.002 & $F$ \\
\hline $7640 \cdot 22 \cdot 6$ & silver & 0.005 & 0.003 & P \\
\hline
\end{tabular}

Analyeical Merhods Used:
$P=16 P$
a - Flone ia

cV = Cold Vapor Aa

FORM I 
DOE/RL-93-96, Rev. 0

Tha Inc.

REPORT

000489

vork order 13.06-092

Results by saaple

FRACTION O2B TEST CODE ICKT

Date 3 Pime collected $06 / 26 / 93$

NAME TCLP. Recals form 1

Caregory

ICLP METALS

Sample Matrix: HATER

TCLP Extraction Date: 07/08/93

Dase Received: 06/30/93

\begin{tabular}{|c|c|c|c|c|}
\hline CAS No. & COMPOUNO & $\begin{array}{l}\text { RESULT } \\
(m g / L)\end{array}$ & $\begin{array}{c}P O L \\
(m g / L)\end{array}$ & METHOD \\
\hline $7640-38-2$ & Arsenic & 0.001 & 0.001 & $F$ \\
\hline $7640 \cdot 39 \cdot 3$ & Bariun & 0.567 & 0.001 & $p$ \\
\hline $7640-43-9$ & Cadmiun & 0.001 & 0.003 & $p$ \\
\hline $7460 \cdot 47 \cdot 3$ & Chromi un & 0.107 & 0.007 & $p$ \\
\hline $7639.92-1$ & Lead & 0.008 & 0.001 & $F$ \\
\hline $7639 \cdot 97 \cdot 6$ & Mereury & 0.0026 & 0.0002 & cv \\
\hline $7782 \cdot 69 \cdot 2$ & selentum & No & 0.002 & $p$ \\
\hline $7640 \cdot 22-6$ & sitver & 0.078 & 0.006 & $p$ \\
\hline
\end{tabular}

Analyeleal Methods used:
$P=I C P$
$i=$ flame AA
F Furnace $1 A$
$C V=$ Cold VaF:- iA

FORM 1

B. 1-21 
From: Geochemistry \& Hydrochemistry

Phone: $\quad 376-3324$

Date: $\quad$ December 3, 1993

Subject: DATA VALIDATION OF 300-FF-1 SOIL WASHING COLLECTED JUNE 1993

To: R. D. Belden

CC: J. C. Johnston
D. G. Horton

This report is to document the validation of 300-FF-1 Soil Washing data collected during JUNE 1993. The validation was based on WHC-CM-7-8 manual "Environmental Engineering and Geotechnology Function Procedures" (WHC 1992) and the "Annual Report for RCRA Groundwater Monitoring Projects at Hanford Site Facilities for 1992" Appendix B DOE/RL-93-09 (DOE-RL, 1993a).

The data were collected, analyzed and processed in a similar manner as the Resource Conservation and Recovery Act (RCRA) groundwater monitoring projects. The analytical

laboratories utilized were Datachem Laboratory, Salt Lake City Utah and International Technology Analytical Services, Richland, Washington. Data validation was performed by Ms. P.B. Freeman, RCRA Sampling and Analysis Task Leader. A electronic copy of the data is provide in both paradox and lotus format. Hardcopies of data were provided prior to this report.

Data validation consisted of seven parts:

a. $100 \%$ verification that requested data were received.

b. $100 \%$ verification that holding times were meet.

c. $100 \%$ evaluation of precision with field duplicates

d. $100 \%$ evaluation of potential sample contamination with field blank data.

e. $100 \%$ evaluation of laboratory MS/MSD and surrogate data through laboratory incident reports.

f. $100 \%$ evaluation of laboratory blanks.

g. $100 \%$ evaluation of data completeness.

The outcome of the validation:

Part a: All data requested were not received. Sample numbers $\mathrm{B} 07 \mathrm{C} 86$ and $\mathrm{B} 07 \mathrm{C} 87$ were not received. These were for VOA analyses only as they were Trip blank \# 3 and Trip blank \#4, respectfully.

Part b: All analytical holding times were not met. VOA analyses for the following samples numbers exceeded required holding times. These data have been flagged with " $H$ " validation flag. The H-flagged data can be used 
qualitatively, but no regulatory decisions should be made based on a single flagged analytical result. The sample numbers are $\mathrm{B} 07 \mathrm{C} 77, \mathrm{~B} 07 \mathrm{C79}$, B07C80, B07C81, B07CB2, B07CB3, B07C71.

Part c:

Evaluation of Duplicate data was performed using procedure 2.1 "Evaluation of RCRA Groundwater Field Duplicate and Blank Sample Data" (WHC 1992) and using Appendix B (DOE-RL 1993).

There were two water matrix and three soil matrix duplicate pairs evaluated. The water matrix paired sample numbers are B07C71 with $B 07 C 72$ and $B 07 C 76$ with $B 07 C 85$, respectfu11y. The evaluation identifies constituents which exceeded a required 25\% relative percentage difference (WHC 1992) and was above the limit of detection as defined in Appendix $B$ (DOE-RL 1993).

The evaluation of $\mathrm{BO} C \mathrm{C} 1 \mathrm{l}$ and $\mathrm{B} 07 \mathrm{C} 72$ identified one constituent. The constituent is chloroform which was analyzed by method SW-846 8240 .

The evaluation of $\mathrm{B} 07 \mathrm{C} 76$ and $\mathrm{B} 07 \mathrm{C} 85$ identified one constituent. The constituent is barium which was analyzed by method SW-846 6010 .

The soil matrix paired sample numbers are $\mathrm{B} 07 \mathrm{C} 31$ with $\mathrm{B} 07 \mathrm{C} 68$ $B 07 C 97$ with $\mathrm{B} 07 \mathrm{CB} 1$ and $\mathrm{B} 07 \mathrm{C} 11$ with $\mathrm{B} 07 \mathrm{C} 67$, respectfully. The evaluation of $B 07 C 31$ and $B 07 C 68$ identified four constituents. The constituents are tin which was analyzed by method SW-846 6010; Arsenic which was analyzed by method SW-846 7060; uranium and radium-224 which were analyzed by International Technology Analytical Services inhouse methods.

The evaluation of $B 07 C 97$ and $B 07 C B 1$ identified ten constituents. The constituents are aluminum, barium, calcium, chromium, copper, nickel, sodium which were analyzed by method SW-846 6010; lead which is analyzed by method SW-846 7421; arsenic which is analyzed by method SW8467060 and uranium which was analyzed by International Technology Analytical Services inhouse method.

The evaluation of $\mathrm{BOTC11}$ and $\mathrm{BOTC67}$ identified nine constituents. The constituents are antimony, barium, chromium, copper, tin which were analyzed by method SW-846 6010; and uranium, cesium-137, lead-212, radium-224 which were analyzed by International Technology Analytical Services inhouse methods.

As a result of this evaluation all data associated with these sample numbers and constituents are flagged with a validation flag of $Q$. The Q-flagged data can be used qualitatively, but not regulatory decisions should be made based on a single flagged data point. 
Part d: Evaluation of field blank data was performed using procedure 2.1 "Evaluation of RCRA Groundwater Field Duplicate and Blank Sample Data" (WHC 1992) and using Appendix B (DOE-RL 1993).

There were six water blanks collected during the June 1993 sampling. Results from two blanks were not received (see part a). The blanks exceeding two times the method detection limit (MDL) were flagged with a $Q$ (WHC 1992). MDL are defined in Appendix B (DOE-RL 1993). The sample numbers for the water blanks are B07C73, B07C74, B07CB2, B07CB3, B07C86 and B07C87. Only samples B07CB2 and B07CB3 had one constituent exceed two times the MDL. The constituent was the same for each sample number and was methylene chloride which is analyzed by method SW-846 8240 .

As a result of this evaluation the above constituents associated with the collect and analyze dates of these sample numbers and constituents are flagged with a validation flag of $Q$. The $Q$-flagged data can be used qualitatively, but not regulatory decisions should be made based on a single flagged data point.

Part e: There were three laboratory incident reports for this data. One incident report consisted of a sample analyzed by wrong uranium in-house method and was reanalyzed properly and reported without comment code. The other two reports described matrix interference which caused higher detection limits and false results in the gamma scan analysis. The effected samples for the gamma scan are flagged with a XYZ in the comment code. All the incident reports are attached for information. Otherwise, no data was found to have matrix spike, matrix spike dupilicate or surrogate samples exceeding laboratory acceptance criteria.

Part $f$ : There were no " $B$ " qualifiers associated with these data, therefore no laboratory blanks exceeded laboratory acceptance criteria.

Part g: The data completeness is determined after data validation is completed and is calculated by the number of unflagged divided by the total number of validated data expressed as a percentage. The RCRA using a $80 \%$ acceptance guidance. The total number of soil data are 1302 constituents and water data are 578 constituents. The total unflagged soil data are 1256 constituents and water data are 421 constituents. The calculated completeness for soil and water data are $96.5 \%$ and $73 \%$, respectfully. The soil data is within acceptable completeness criteria. The water data is below acceptable completeness criteria and may need to be evaluated further for its regulatory uses. 


\section{References:}

DOE-RL, 1993, Annual Report for RCRA Groundwater monitoring Projects at Hanford Site Facilities for 1992, DOE/RL93-09, U.S. Department of Energy, Richland Operations Office, Richland, Washington.

WHC, 1992, Environmental Engineering and Geotechnology Function Procedures, WHC-CM-78, vol. 4, Westinghouse Hanford Company, Richland, Washington.

P. B. Freeman

RCRA Sampling and Analysis Task Team Leader

pbf 
DOE/RL-93-96, Rev. 0

B.2 ANALYTICAL DATA FOR TEST \#2

B. 2-1 
DOE/RL-93-96, Rev. 0

B. 2-2 
DOE/RL-93-96, Rev. 0

\begin{tabular}{|c|c|c|c|c|c|}
\hline & \multicolumn{5}{|c|}{ SEPTEMBER 1993 PROCESSING } \\
\hline & $\begin{array}{r}070 P 9 \\
\text { Poil } \\
\mathrm{mg} / \mathrm{kg}\end{array}$ & $\begin{array}{r}807000 \\
\text { soil } \\
\mathrm{mg} / \mathrm{kg}\end{array}$ & $\begin{array}{r}\text { BO7DOI } \\
\text { soil } \\
\mathrm{mg} / \mathrm{kg}\end{array}$ & $\begin{array}{r}807002 \\
\text { voil } \\
\mathrm{mg} / \mathrm{kg}\end{array}$ & $\begin{array}{r}807003 \\
\text { soil } \\
\mathrm{mg} / \mathrm{kg}\end{array}$ \\
\hline Ac & 3.2 & 4.6 & 2.8 & 2.6 & 4.8 \\
\hline Al & 12000 & 14000 & 13000 & 10000 & 7600 \\
\hline Ba & 150 & 130 & 130 & 98 & 88 \\
\hline Bo & 0.33 & $0.28 \mathrm{~L}$ & 0.45 & 0.41 & $0.17 \mathrm{~L}$ \\
\hline c. & 7800 & 7100 & 8300 & 9800 & 6000 \\
\hline Cd & $\underline{u}$ & $u$ & $u$ & $u$ & $u$ \\
\hline Co & 13 & 13 & 14 & 12 & 11 \\
\hline Cr & 22 & 28 & 17 & 17 & 17 \\
\hline $\mathrm{Cu}$ & 250 & 380 & 160 & 160 & 240 \\
\hline Fe & 33000 & 33000 & 38000 & 32000 & 30000 \\
\hline $\mathrm{Hg}_{\mathrm{g}}$ & 0.45 & $0.14 L$ & $u$ & $0.16 \mathrm{~L}$ & 0.126 \\
\hline K & 1500 & 1700 & 1500 & 1100 & 670 \\
\hline$M_{0}$ & 6600 & 7200 & 6900 & 6000 & 5000 \\
\hline$M n$ & 690 & 510 & 650 & 460 & 380 \\
\hline $\mathrm{Na}$ & 480 & 440 & 440 & 440 & 430 \\
\hline NI & 30 & 31 & 24 & 23 & 36 \\
\hline$P$ & 7 & 7.4 & 5 & 3.9 & 5.1 \\
\hline$s b$ & $5.8 \mathrm{~L}$ & 71 & $5.6 \mathrm{~L}$ & $5.8 \mathrm{~L}$ & $u$ \\
\hline $8 n$ & $u$ & $u$ & $u$ & $u$ & v \\
\hline$v$ & 86 & 87 & 91 & 89 & 88 \\
\hline $2 n$ & 73 & 77 & 72 & 68 & 63 \\
\hline & $\mathrm{PC} / \mathrm{O}$ & $\mathrm{pCl/a}$ & $\mathrm{pCl} / \mathrm{O}$ & $\mathrm{CCl} / \mathrm{o}$ & $\mathrm{pCl} / \mathrm{d}$ \\
\hline Co. 60 & $0.0237 \mathrm{U}$ & 0.117 & 0.0496 & 0.070 & 0.31 \\
\hline C..137 & 0.0041 & 0.0906 & 0.0316 & $0.0628 \mathrm{U}$ & 0.0723 \\
\hline po.212 & 0.000 & 0.689 & 0.531 & 0.538 & 0.60 \\
\hline $\mathrm{Pb}-214$ & 0.467 & 0.506 & 0.479 & 0.428 & 0.496 \\
\hline Ro.-224 & 0.012 & 0.693 & 0.636 & 0.637 & 0.693 \\
\hline Ro-220 & 0.486 & 0.616 & 0.30 & 0.344 & 0.496 \\
\hline Ru-100 & $.0 .0900 \mathrm{U}$ & 0.194 & $0.00646 \mathrm{U}$ & $0.118 \mathrm{U}$ & $0.118 \mathrm{U}$ \\
\hline $8 b-128$ & 0.0481 & $0.00082 \mathrm{U}$ & $0.0314 \mathrm{U}$ & $.0 .00754 \mathrm{U}$ & $.0 .0378 \mathrm{U}$ \\
\hline & $\mathrm{PCNg}$ & $\mathrm{pC} / \mathrm{o}$ & $\mathrm{pCl} / \mathrm{O}$ & $\mathrm{pCl} / \mathrm{O}$ & $\mathrm{pCl} / \mathrm{g}$ \\
\hline U. Nat & 3.66 & 13.3 & 1.72 & 2.73 & 0.13 \\
\hline & mo/ko & $\mathrm{mo} / \mathrm{kg}$ & $\mathrm{mo} / \mathrm{kg}_{\mathrm{g}}$ & mo/kg & $\mathrm{mo} / \mathrm{kg}$ \\
\hline Aroelon-1018 & $u$ & $u$ & $u$ & $u$ & $u$ \\
\hline Aroolon-1221 & $\underline{u}$ & $u$ & $u$ & $u$ & $u$ \\
\hline Aroclor-1 232 & $u$ & $u$ & $u$ & $u$ & $u$ \\
\hline Aroolon 1242 & $u$ & $u$ & $u$ & $u$ & $u$ \\
\hline Aroclor-1248 & $0.064 \mathrm{~L}$ & $0.091 \mathrm{~L}$ & $0.0089 \mathrm{~L}$ & $0.012 \mathrm{~L}$ & 0.12 \\
\hline Aroclor.1264 & $\underline{u}$ & $\underline{u}$ & $u$ & $u$ & $\underline{u}$ \\
\hline Aroclor-1260 & $u$ & $\mathbf{u}$ & $u$ & $u$ & $u$ \\
\hline
\end{tabular}


DOE/RL-93-96, Rev. 0

\begin{tabular}{|c|c|c|c|c|}
\hline \multicolumn{5}{|c|}{$\begin{array}{c}\text { TEST "2 SOIL WASHING RESULTS } \\
\text { FRESH WATER (UNFILTERED) }\end{array}$} \\
\hline & \multicolumn{4}{|c|}{ SEPTEMRER 1993 PROCESSING } \\
\hline & $\begin{array}{r}807004 \\
\text { water } \\
\text { mo/l }\end{array}$ & $\begin{array}{r}8070 \times 8 \\
\text { dup. } \\
\mathrm{mg} / \mathrm{L}\end{array}$ & $\begin{array}{r}\text { Bo70as } \\
\text { water } \\
\mathrm{mg} / \mathrm{L}\end{array}$ & $\begin{array}{r}\text { B070x9 } \\
\text { dup. } \\
\text { mo/l }\end{array}$ \\
\hline Ag & vo & $0.008 \mathrm{La}$ & va & $0.0047<0$ \\
\hline A! & $u$ & $u$ & $u$ & $u$ \\
\hline en & 0.0300 & 0.030 & 0.028 & 0.027 \\
\hline 8 & $u$ & $\mathbf{u}$ & $u$ & U \\
\hline $\mathbf{C a}_{\mathbf{n}}$ & $38 a$ & 270 & 24 & 24 \\
\hline Cd & $\mathbf{u}$ & $u$ & $\mathbf{u}$ & $\mathbf{u}$ \\
\hline Co & $\mathbf{u}$ & u & $u$ & U \\
\hline Cr & $u$ & $0.0062 \mathrm{~L}$ & $u$ & $u$ \\
\hline $\mathrm{Cu}$ & 0.0780 & 0.0380 & $0.0054 \mathrm{La}$ & vo \\
\hline $\mathbf{F e}$ & 1.6 & 1.3 & 0.12 & 0.13 \\
\hline $\mathrm{Ho}$ & U & $u$ & $\mathbf{u}$ & $\mathbf{u}$ \\
\hline K & 30 & 2.10 & 1.00 & 2.10 \\
\hline Mo & 8.00 & 0.20 & 5.3 & 6.4 \\
\hline $\mathrm{Mn}$ & $0.087 \mathrm{a}$ & $0.032 \mathrm{a}$ & $0.0063 \mathrm{~L}$ & $0.0000 \mathrm{~L}$ \\
\hline Ne & 9.60 & 6.30 & 4.3 & 4.1 \\
\hline NI & $u$ & $u$ & $\mathbf{u}$ & $u$ \\
\hline$P_{t}$ & $0.037 \mathrm{a}$ & 0.010 & 0.00087 i & $0.0016 \mathrm{~L}$ \\
\hline $8 b$ & $\mathbf{u}$ & $u$ & $u$ & u \\
\hline sn & $\mathbf{u}$ & $\underline{u}$ & $u$ & u \\
\hline$v$ & $\mathbf{u}$ & $u$ & $0.0053 \mathrm{~L}$ & u \\
\hline $2 n$ & .0 .0240 & $0.012 a$ & $u$ & $0.0046 \mathrm{~L}$ \\
\hline & $\mathrm{PCl} / \mathrm{L}$ & pcul & $\mathrm{pCl} / \mathrm{L}$ & $\mathrm{DCl} / \mathrm{L}$ \\
\hline Co-60 & $0.146 \mathrm{U}$ & 5.26 & $1.29 \mathrm{U}$ & $4.56 \mathrm{U}$ \\
\hline C.-137 & $1.39 \mathrm{U}$ & $4.51 \mathrm{U}$ & $3.1 \mathrm{U}$ & $3.3 \mathrm{U}$ \\
\hline$R u-100$ & $.44 .3 U$ & $4.35 \mathrm{U}$ & $.32 .3 \mathrm{U}$ & $.0 .728 \mathrm{U}$ \\
\hline $5 b \cdot 128$ & $6.77 \mathrm{U}$ & $-3.18 U$ & $12.2 \mathrm{U}$ & $-18.3 U$ \\
\hline & $\omega 0 / 1$ & $\omega 0 / L$ & uv/L & uoll \\
\hline U.Net & $1.03 \mathrm{a}$ & 0.0930 & 0.005 & 0.702 \\
\hline & $m g / h$ & $m o / L$ & $m o / l$ & $m o / L$ \\
\hline Aroolon-1016 & $u$ & $u$ & $\mathbf{u}$ & u \\
\hline Aroolor 1221 & $\mathbf{u}$ & $u$ & $u$ & u \\
\hline Aroolon 1232 & $u$ & $u$ & $u$ & u \\
\hline Aroolor-1242 & $u$ & $u$ & $u$ & U \\
\hline Aroobr-1248 & $u$ & $u$ & $u$ & $\mathbf{u}$ \\
\hline Arooton-1254 & $u$ & $u$ & $u$ & U \\
\hline Aroolom 1200 & $u$ & $\mathbf{u}$ & $u$ & $\mathbf{u}$ \\
\hline
\end{tabular}

Uananalyzed for but undatected

Quoata can be used qualitatively

Laleas then CROL and above rol 
D0E/RL-93-96, Rev. 0

\begin{tabular}{|c|c|c|c|c|c|c|c|c|c|c|c|c|}
\hline \multicolumn{13}{|c|}{$\begin{array}{l}\text { TEST W2 SOIL WASHING RESULTS } \\
25 \mathrm{~mm} \text { TO } 2 \mathrm{~mm} \\
\end{array}$} \\
\hline & \multicolumn{12}{|c|}{ SEPTEMAER 1993 PROCEESING } \\
\hline & $\begin{array}{r}\text { Bo70v2 } \\
\text { eoll } \\
\text { mo/kg }\end{array}$ & $\begin{array}{r}8070 V_{3} \\
\text { coll } \\
\text { manko }\end{array}$ & $\begin{array}{r}8070 \mathrm{~V} 4 \\
\text { eoll } \\
\text { mo/kg }\end{array}$ & $\begin{array}{r}\text { 6070vs } \\
\text { coll } \\
\text { mo/kg }\end{array}$ & $\begin{array}{r}8070 \mathrm{Vo}^{8} \\
\text { eoll } \\
\mathrm{mo} / \mathrm{kg}^{\prime}\end{array}$ & $\begin{array}{r}8070 \mathrm{~V} 7 \\
\mathrm{coll} \\
\mathrm{mo/ko}\end{array}$ & $\begin{array}{r}\text { BOzDV } \\
\text { soll } \\
\mathrm{mg} / \mathrm{kg}\end{array}$ & $\begin{array}{r}8070 \mathrm{Vg} \\
20 i l \\
\mathrm{mo/kg}\end{array}$ & $\begin{array}{r}8070 \text { Wo } \\
\text { soll } \\
\mathrm{mo} / \mathrm{kg}\end{array}$ & $\begin{array}{r}070 W_{1} \\
\text { soll } \\
\text { mo/kg }\end{array}$ & $\begin{array}{r}8070 W 2 \\
\text { soll } \\
\mathrm{mg} / \mathrm{kg}\end{array}$ & $\begin{array}{r}\text { BO70W3 } \\
\text { soll } \\
\text { ma/kg }\end{array}$ \\
\hline Ae & 1.26 & 14 & $0.73 \mathrm{~L}$ & $1.1 \mathrm{~L}$ & $0.84 \mathrm{l}$ & $0.86 \mathrm{~L}$ & $0.07 \mathrm{~L}$ & $0.80 \mathrm{~L}$ & $1.1 \mathrm{~L}$ & $0.98 \mathrm{~L}$ & $0.76 \mathrm{~L}$ & $0.78 \mathrm{~L}$ \\
\hline$\Delta 1$ & 4000 & 8700 & 4200 & 8400 & 3000 & 8400 & 4000 & 3600 & 4100 & 3400 & 3100 & 3900 \\
\hline a & 67 & 48 & 61 & $\infty$ & 81 & 73 & 86 & 69 & 71 & 60 & 80 & $\infty$ \\
\hline 8 & $0.20 \mathrm{~L}$ & 0.221 & $0.13 L$ & 0.31 & $0.13 L$ & 0.31 & 0.21 & $0.23 \mathrm{~L}$ & $0.28 \mathrm{~L}$ & $0.23 \mathrm{~L}$ & 0.131 & $0.10 L$ \\
\hline c. & 8600 & 8000 & 4400 & 6800 & 6100 & 7000 & 8600 & 4800 & 5600 & 4900 & 8500 & 4600 \\
\hline Cd & $u$ & $u$ & v & $u$ & $u$ & $u$ & $u$ & $u$ & $u$ & $u$ & $u$ & $u$ \\
\hline Co & 9.4 & 9.7 & 7.8 & 11 & 8.6 & 10 & 8.0 & 8.8 & 11 & 8.8 & 7.7 & 8.1 \\
\hline$c r$ & 6.3 & 4.3 & 3.2 & 4.8 & 3.9 & 4.8 & 2.7 & 3.3 & 4.7 & 6 & 2.1 & 4.3 \\
\hline $\mathrm{Cu}$ & 240 & 140 & 140 & 270 & 100 & 60 & 180 & 180 & 100 & 130 & 30 & 100 \\
\hline 5 & 20000 & 24000 & 31000 & 22000 & 22000 & 20000 & 24000 & 23000 & 20000 & 26000 & 22000 & 21000 \\
\hline 40 & $u$ & u & $u$ & $u$ & $u$ & u & $u$ & $u$ & $u$ & $u$ & $u$ & $u$ \\
\hline $\mathbf{x}$ & 40 & 200 & 360 & 270 & 230 & 350 & 280 & 240 & 290 & 360 & 200 & 380 \\
\hline$m_{0}$ & 3700 & 3200 & 2900 & 3700 & 3000 & 3000 & 3000 & 3400 & 4700 & 2500 & 3100 & 4200 \\
\hline $\operatorname{mn}$ & 200 & 200 & 220 & 340 & 240 & 270 & 310 & 250 & 340 & 290 & 210 & 180 \\
\hline Na & 200 & 370 & 240 & 480 & 310 & 800 & 330 & 320 & 310 & 320 & 220 & 200 \\
\hline$N$ & 16 & 0.8 & 7.7 & 13 & 7.8 & 7 & 12 & 10 & 12 & 6.8 & 4.1 & 6.7 \\
\hline$\infty$ & 2 & 2.4 & 2.1 & 2.8 & 1.1 & 1.0 & 1.8 & 1.6 & 1.0 & 2.3 & 1.7 & 1.6 \\
\hline $2 b$ & $u$ & $0.1 \mathrm{~L}$ & $6.3 \mathrm{~L}$ & $u$ & $4.6 \mathrm{~L}$ & $v$ & $u$ & $u$ & $4.4 \mathrm{~L}$ & $u$ & $u$ & $u$ \\
\hline en & $u$ & $u$ & $u$ & $u$ & $u$ & u & $u$ & $u$ & $u$ & $u$ & $u$ & $u$ \\
\hline$v$ & 78 & 6 & 02 & 71 & 62 & 60 & 41 & 67 & 73 & 70 & 88 & 46 \\
\hline \multirow[t]{2}{*}{$2 n$} & 53 & 83 & 64 & 04 & 81 & 80 & 40 & 48 & 53 & 40 & 46 & 42 \\
\hline & $p C V_{0}$ & $\mathrm{PCV}$ & pave & $\mathrm{C} / \mathrm{de}$ & $\mathrm{pC} / \mathrm{a}$ & pciva & $\mathrm{pC} / \mathrm{do}$ & $\mathrm{Cl} / \mathrm{a}$ & $\mathrm{pCl} / \mathrm{e}$ & $\mathrm{pCl} / \mathrm{g}$ & $\mathrm{PC} / \mathrm{g}$ & $\mathrm{pCl} / \mathrm{g}$ \\
\hline $\cos 60$ & 0.120 & 0.185 & 0.128 & 0.133 & 0.034 & 0.0800 & 0.168 & 0.08 & 0.0947 & 0.0643 & 0.12 & 0.0793 \\
\hline C.-137 & 0.121 & 0.124 & 0.116 & 0.180 & 0.0587 & 0.101 & 0.107 & 0.113 & 0.0003 & 0.116 & 0.112 & 0.106 \\
\hline$P_{0}-212$ & 0.676 & 0.823 & 0.463 & 0.40 & 0.520 & 0.493 & 0.004 & 0.741 & 0.536 & 0.027 & 0.600 & 0.563 \\
\hline$p 0-214$ & 0.481 & 0.5 & 0.30 & 0.47 & 0.484 & 0.431 & 0.509 & 0.032 & 0.494 & 0.6 & 0.000 & 0.802 \\
\hline A-224 & 0.570 & 0.620 & 0.460 & 0.403 & 0.620 & 0.496 & 0.607 & 0.746 & 0.54 & 0.032 & 0.091 & 0.567 \\
\hline A-220 & 0.500 & 0.404 & 0.371 & 0.30 & 0.373 & 0.446 & 0.078 & 0.892 & 0.462 & 0.001 & 0.540 & 0.448 \\
\hline Au-100 & -0.0780 & 0.0320 & -0.0300 & -0.0000 & -0.0700 & 0.10 & -0.0330 & -0.0324 & -0.00440 & -0.02810 & .0 .0070 & .0 .0430 \\
\hline \multirow[t]{2}{*}{$80-128$} & -0.0010 & -0.0000 & -0.0044 & -0.0440 & -0.0000 & -0.0010 & 0.00 & -0.0000 & $0.0121 U$ & $0.0482 \mathrm{U}$ & -0.0180 & $0.003 \mathrm{U}$ \\
\hline & $\mathrm{Ca} / \mathrm{a}$ & $\mathrm{pCl} / \mathrm{a}$ & $\mathrm{Cava}$ & $\mathrm{CN}$ & $\mathrm{DCN}$ & $\mathrm{pCV} / \mathrm{g}$ & $\mathrm{CN} / \mathrm{a}$ & $\mathrm{pCl} / \mathrm{o}$ & $\mathrm{pCl} / \mathrm{o}$ & $\mathrm{PC} / \mathrm{g}$ & $\mathrm{pC} / \mathrm{p}$ & $\mathrm{pCl} / \mathrm{a}$ \\
\hline \multirow[t]{2}{*}{$U-\mathrm{Nat}$} & 2.01 & 1.37 & 1.33 & 2.02 & 0.912 & 1.83 & 2.13 & 0.067 & 1.23 & 1.07 & 1.32 & 1.4 \\
\hline & mo/ke & maknel & make & makg & $\mathrm{ma} / \mathrm{kg}$ & mo/ko & mokg & mo/kg & $\mathrm{mo} / \mathrm{kg}$ & mokns & $\mathrm{mo} / \mathrm{kg}$ & $\mathrm{ma} / \mathrm{kg}$ \\
\hline Areolor-1018 & $u$ & $u$ & $u$ & $u$ & $u$ & u. & $u$ & $u$ & $u$ & $u$ & $u$ & u \\
\hline Aroolor.1221 & $u$ & u & $u$ & $u$ & $v$ & $u$ & 0 & $u$ & $u$ & $u$ & $u$ & $u$ \\
\hline Aroolor. 1232 & $u$ & u & $u$ & $u$ & $u$ & $u$ & $u$ & $u$ & $u$ & $u$ & $u$ & $u$ \\
\hline Areoler-1242 & $u$ & u & $u$ & $u$ & $u$ & $u$ & $u$ & $u$ & $u$ & $u$ & $u$ & $u$ \\
\hline Areeler-1240 & .00471 & .00074 & .00301 & $.020 \mathrm{~L}$ & .00416 & $.0062 \mathrm{~L}$ & .00471 & $.0040 \mathrm{~L}$ & $.0024 \mathrm{~L}$ & $.0033 \mathrm{~L}$ & .00401 & $.0004 \mathrm{~L}$ \\
\hline Aroolor-1264 & $u$ & $u$ & $u$ & $u$ & $u$ & $u$ & $u$ & $u$ & $u$ & $u$ & $u$ & $u$ \\
\hline Areolor-1200 & $v$ & $u$ & $u$ & $v$ & $v$ & $u$ & $\mathbf{v}$ & $\mathbf{u}$ & $\mathbf{u}$ & $u$ & $u$ & $u$ \\
\hline
\end{tabular}


DOE/RL-93-96, Rev. 0

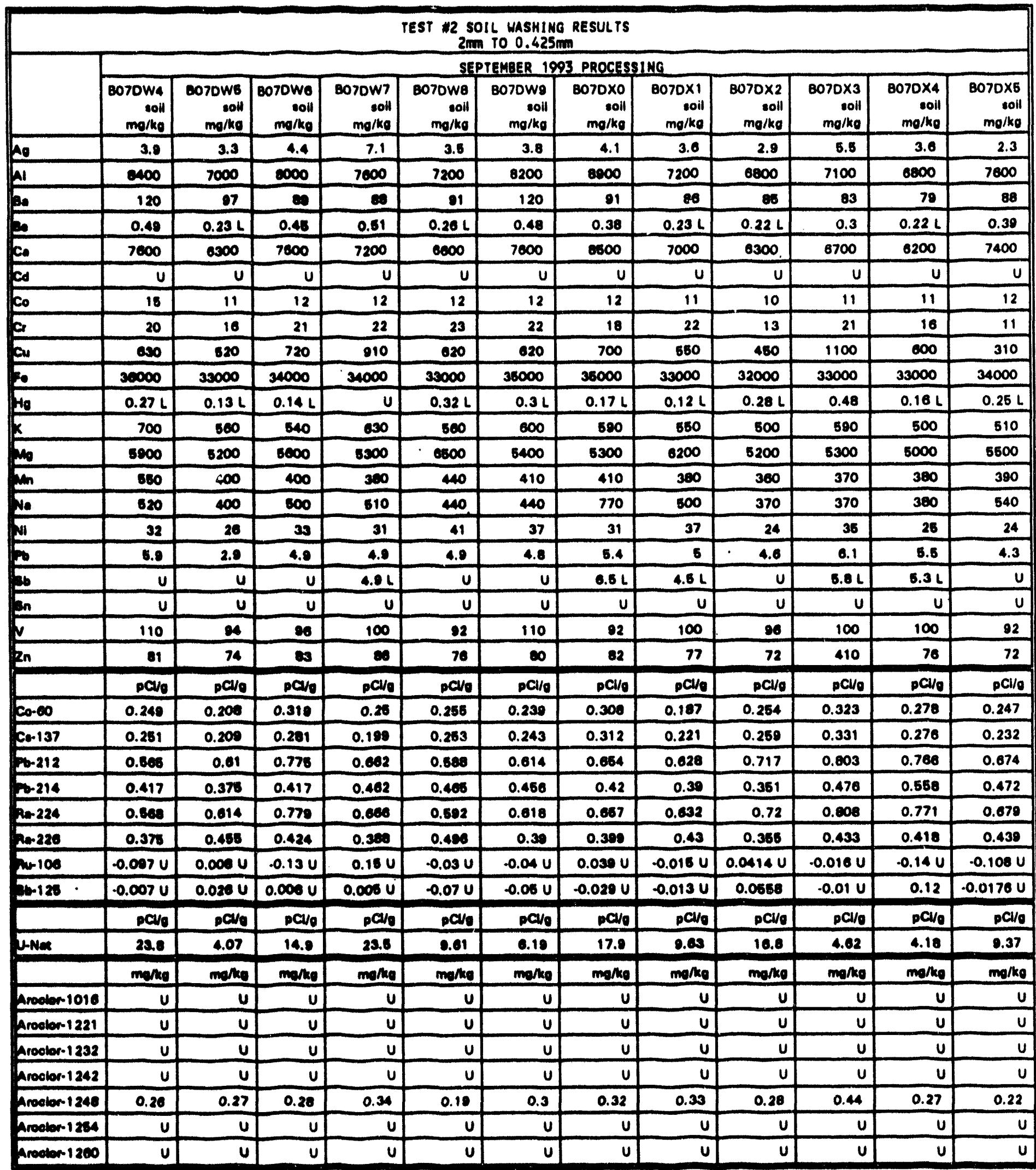


DOE/RL-93-96, Rev. 0

\begin{tabular}{|c|c|c|c|}
\hline \multicolumn{4}{|c|}{$\begin{array}{l}\text { TEST W2 SOIL WASHING RESULTS } \\
\text { MINUS } 0.425 \mathrm{~mm} \text { SLURRY SOILS }\end{array}$} \\
\hline & \multicolumn{3}{|c|}{ SEPTEMBER 1993 PROCESSING } \\
\hline & $\begin{array}{r}\text { B07Ds7 } \\
\text { soll } \\
\mathrm{mo} / \mathrm{kg} \\
\end{array}$ & $\begin{array}{r}\text { B070S8 } \\
\text { ooil } \\
\mathrm{mg} / \mathrm{kg} \\
\end{array}$ & $\begin{array}{r}\text { BO70S9 } \\
\text { soil } \\
\mathrm{mg} / \mathrm{ko} \\
\end{array}$ \\
\hline Ag & 3.2 & 6.6 & 4.4 \\
\hline Al & 8600 & 7800 & 7200 \\
\hline B. & 330 & 240 & 90 \\
\hline 8 & $u$ & $u$ & $0.13 \mathrm{~L}$ \\
\hline C. & 5600 & 4600 & 5100 \\
\hline cd & $u$ & $u$ & $u$ \\
\hline Co & 7.6 & 7.6 & 8.3 \\
\hline Cr & 54 & 46 & 24 \\
\hline $\mathrm{Cu}$ & 360 & 700 & 680 \\
\hline Fe & 25000 & 24000 & 24000 \\
\hline Ho & 0.43 & $0.31 \mathrm{~L}$ & $u$ \\
\hline $\mathbf{K}$ & 730 & 730 & 590 \\
\hline Mo & 4100 & 4100 & 4300 \\
\hline $\operatorname{Mn}$ & 250 & 300 & 310 \\
\hline Na & 460 & 330 & 320 \\
\hline NI & 38 & 42 & 36 \\
\hline Pb & 16 & 16 & 6.9 \\
\hline 86 & $u$ & $u$ & $u$ \\
\hline $\operatorname{sn}$ & 11 & $9.5 \mathrm{~L}$ & $u$ \\
\hline $\mathbf{v}$ & 71 & 68 & 73 \\
\hline $2 n$ & 52 & 92 & 83 \\
\hline & $\mathrm{pCl} / \mathrm{g}$ & $\mathrm{pCl} / \mathrm{o}$ & $\mathrm{pCl} / \mathrm{o}$ \\
\hline Co-60 & 0.0412 & 0.256 & 0.431 \\
\hline Co-137 & 0.212 & 0.287 & 0.322 \\
\hline Po-212 & 1.21 & 1.07 & 0.868 \\
\hline $\mathrm{Pb}-214$ & 0.822 & 0.657 & 0.564 \\
\hline Ac-224 & 1.21 & 1.07 & 0.872 \\
\hline Re-226 & 0.72 & 0.622 & 0.554 \\
\hline Ru-106 & $0.286 \mathrm{U}$ & $0.292 \mathrm{U}$ & $.0 .0898 \mathrm{U}$ \\
\hline $8 b-125$ & $0.0271 U$ & $0.0179 \mathrm{U}$ & $0.0302 \mathrm{U}$ \\
\hline & $\mathrm{pCl} / \mathrm{g}$ & $\mathrm{pC} / / \mathrm{o}$ & $\mathrm{pCl} / \mathrm{g}$ \\
\hline$U \cdot N a t$ & 116 & 134 & 31.8 \\
\hline & ma/ko & mo/kg & $\mathrm{mo} / \mathrm{ko}$ \\
\hline Aroolom 1016 & $u$ & $u$ & $u$ \\
\hline Areclor-1221 & $u$ & $u$ & $u$ \\
\hline Aroclor-1 232 & $u$ & $u$ & $u$ \\
\hline Aroolor-1242 & $u$ & $u$ & $u$ \\
\hline Aroolor-1248 & 0.97 & 0.66 & 0.36 \\
\hline Arocior-1254 & $u$ & $u$ & $u$ \\
\hline Aroctor-1260 & u & $\mathbf{u}$ & $u$ \\
\hline
\end{tabular}

\section{B. 2-7}


DOE/RL-93-96, Rev. 0

\begin{tabular}{|c|c|c|c|c|c|c|c|c|}
\hline & \multicolumn{8}{|c|}{$\begin{array}{c}\text { TEST W2 SOIL WASHING RESULTS } \\
\text { MINUS } 0.425 \text { SLURRY WATER } \\
\end{array}$} \\
\hline & \multicolumn{8}{|c|}{ SEPTEMBER 1993 PROCESSIMG } \\
\hline & $\begin{array}{c}\text { 8070T2 } \\
\text { water-ul } \\
\mathrm{mo} / \mathrm{L}\end{array}$ & $\begin{array}{r}\text { 8070T3 } \\
\text { water-f } \\
\mathrm{mg} / \mathrm{L}\end{array}$ & $\begin{array}{r}\text { BO7DT4 } \\
\text { water-uf } \\
\mathrm{mg} / \mathrm{L}\end{array}$ & $\begin{array}{r}8070 T 5 \\
\text { water-1 } \\
\mathrm{mg} / \mathrm{L}\end{array}$ & $\begin{array}{r}\text { BO7DT6 } \\
\text { water-uf } \\
\mathrm{mg} / \mathrm{L} \\
\end{array}$ & $\begin{array}{r}\text { BO70T7 } \\
\text { water-f } \\
\mathrm{mg} / \mathrm{L} \\
\end{array}$ & $\begin{array}{r}\text { BO7DT8 } \\
\text { water-uf } \\
\mathrm{mg} / \mathrm{L}\end{array}$ & $\begin{array}{r}\text { Bo70vo } \\
\text { water-uf } \\
\mathrm{mo} / \mathrm{L}\end{array}$ \\
\hline Ao & 0.033 & $u$ & 0.023 & $0.0042 \mathrm{~L}$ & $0.014 \mathrm{~L}$ & $u$ & $0.0079 \mathrm{~L}$ & $0.0076 \mathrm{~L}$ \\
\hline Al & 28 & $0.16 \mathrm{~L}$ & 15 & $\mathbf{u}$ & 12 & $0.044 \mathrm{~L}$ & 4.4 & 4.8 \\
\hline Ba & 1.9 & 0.063 & 0.22 & 0.043 & 0.16 & 0.025 & 0.076 & 0.082 \\
\hline Bo & U & $0.0011 \mathrm{~L}$ & $U$ & $\mathbf{u}$ & $u$ & $\underline{u}$ & $\mathbf{u}$ & $\mathbf{u}$ \\
\hline C. & 33 & 10 & 26 & 29 & 27 & 23 & 24 & 25 \\
\hline Cd & $u$ & $\mathbf{u}$ & $u$ & $\mathbf{u}$ & $u$ & $\underline{U}$ & $\mathbf{u}$ & $u$ \\
\hline Co & $0.0084 \mathrm{~L}$ & $u$ & $0.0074 \mathrm{~L}$ & $u$ & $0.006 \mathrm{~L}$ & $U$ & $u$ & $u$ \\
\hline $\mathrm{Cr}$ & 0.27 & $u$ & 0.097 & $u$ & 0.048 & $0.0060 \mathrm{~L}$ & $0.019 \mathrm{~L}$ & 0.022 \\
\hline $\mathrm{Cu}_{\mathrm{u}}$ & 3.8 & $0.019 \mathrm{~L}$ & 1.7 & 0.039 & 0.71 & 0.029 & 0.24 & 0.33 \\
\hline Fe & 18 & 0.089 & 11 & 0.056 & 11 & 0.077 & 3.3 & 3.5 \\
\hline $\mathrm{Ho}$ & 0.0031 & $u$ & 0.0019 & $u$ & 0.0031 & $u$ & 0.00047 & 0.00035 \\
\hline$K$ & 3.4 & 1.2 & 4.1 & 2.8 & 4.2 & 2.4 & 3.6 & 3.9 \\
\hline Mg & 11 & 4,8 & 8.9 & 4.3 & 8.6 & 5.1 & 6.3 & 6.2 \\
\hline Mn & 0.32 & $0.0051 \mathrm{~L}$ & 0.27 & 0.02 & 0.26 & 0.016 & 0.088 & 0.092 \\
\hline Na & 15 & 13 & 7.6 & 5.4 & 6 & 5.1 & 5.4 & 6.2 \\
\hline$N$ & 0.3 & $u$ & 0.008 & $u$ & 0.044 & u & $0.02 \mathrm{~L}$ & $u$ \\
\hline Po & 0.068 & 0.00061 & 0.013 & $u$ & 0.0088 & $0.0012 \mathrm{~L}$ & $0.0021 \mathrm{~L}$ & $0.0035 \mathrm{~L}$ \\
\hline sb & $\mathbf{u}$ & $u$ & $\mathbf{u}$ & $u$ & $u$ & $u$ & $u$ & $\mathbf{u}$ \\
\hline sn & $\mathbf{u}$ & $\mathbf{u}$ & $\mathbf{u}$ & $u$ & 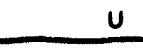 & $\mathbf{u}$ & $\mathbf{U}$ & $u$ \\
\hline$v$ & $0.017 \mathrm{~L}$ & $\mathbf{u}$ & $0.02 \mathrm{~L}$ & $u$ & $0.022 \mathrm{~L}$ & $u$ & $0.0083 \mathrm{~L}$ & $0.0092 \mathrm{~L}$ \\
\hline $2 n$ & 0.18 & $u$ & 0.078 & $u$ & 0.052 & $0.0085 \mathrm{~L}$ & 0.017 & 0.02 \\
\hline & $\mathrm{PCV} / \mathrm{L}$ & DCV/L & $p C A / L$ & $\mathrm{DCVL}$ & $\mathrm{pCl} / \mathrm{L}$ & $\mathrm{pCl} / \mathrm{L}$ & $\mathrm{pCl} / \mathrm{L}$ & $\mathrm{pCl} / \mathrm{L}$ \\
\hline Co- 60 & $3.67 \mathrm{U}$ & $-4.81 U$ & $-1.30 u$ & $-8.24 U$ & $-4.55 U$ & $-4.37 U$ & $6.28 \mathrm{U}$ & $-7.29 \mathrm{U}$ \\
\hline Ce-137 & $2.20 \mathrm{U}$ & $-1.47 \mathrm{U}$ & $.7 .4 \mathrm{U}$ & $-2.24 \mathrm{U}$ & 5.68 & $3.64 \mathrm{U}$ & $.4 .72 U$ & $-2.6 \mathrm{U}$ \\
\hline Ru-100 & $-2.91 U$ & $5.8 \mathrm{U}$ & $25.1 \mathrm{U}$ & $-26.5 \mathrm{U}$ & $10.9 \mathrm{U}$ & OU & $27.8 \mathrm{U}$ & $13 U$ \\
\hline$S b-125$ & $13.2 \mathrm{U}$ & 12.6 & $7.73 \mathrm{U}$ & $-4.7 U$ & $-7.22 \mathrm{U}$ & $-18.4 U$ & $14.4 \mathrm{U}$ & $.5 .76 \mathrm{U}$ \\
\hline & $\omega 0 / L$ & $40 / \mathrm{L}$ & no/L & $40 / 2$ & $\mathrm{ug} / \mathrm{L}$ & uo/L & $40 / L$ & no/L \\
\hline U-Nat & 2.68 & 19.7 & 604 & 510 & 3.16 & 3.68 & 1.40 & 10.9 \\
\hline & $m o / l$ & $\mathrm{mo/h}$ & $m o / L$ & $m g / L$ & $\mathrm{mo} / \mathrm{L}$ & $\mathrm{mo} / \mathrm{L}$ & $\mathrm{mg} / \mathrm{h}$ & $\mathrm{mg} / \mathrm{L}$ \\
\hline Arodor-1016 & $u$ & $u$ & $u$ & $u$ & $u$ & $u$ & $\mathbf{u}$ & $u$ \\
\hline Aroolon 1221 & $u$ & $u$ & $u$ & $u$ & $\mathbf{u}$ & $\mathbf{u}$ & $u$ & $u$ \\
\hline Aroolen 1232 & $u$ & $\mathbf{u}$ & $\mathbf{U}$ & $u$ & $u$ & u & $U$ & $\mathbf{U}$ \\
\hline Aroolon 1242 & $u$ & $u$ & $u$ & $u$ & $u$ & $u$ & $u$ & $u$ \\
\hline Aroolor-1248 & 0.0013 & $\mathbf{u}$ & $0.00078 \mathrm{~L}$ & $\mathbf{U}$ & $0.00028 \mathrm{~L}$ & $\mathbf{u}$ & $\begin{array}{r}0.00025 \\
L\end{array}$ & $0.00021 \mathrm{~L}$ \\
\hline Aroclon 1264 & $u$ & $u$ & $u$ & $u$ & $u$ & $u$ & $u$ & $\mathbf{u}$ \\
\hline Aroolor- 1260 & $u$ & $u$ & $u$ & $u$ & $u$ & $u$ & $\mathbf{U}$ & $U$ \\
\hline
\end{tabular}

Uainalyzed tor but unatected

arouta can be used qualitatively

ufeunfil tered

fafiltered $(0.2 \mu)$

Iress than CRbL and above iol 
DOE/RL-93-96, Rev. 0

\begin{tabular}{|c|c|c|c|c|c|c|c|c|c|c|}
\hline \multicolumn{11}{|c|}{ TEST \#2 SOIL WASHING RESULTS } \\
\hline & \multicolumn{10}{|c|}{ SEPTEMBER 1993 PROCESSING } \\
\hline & \multicolumn{2}{|c|}{ FRESH UATER } & \multicolumn{5}{|c|}{ MINUS $0.425 \mathrm{~mm}$ SLURRY WATER } & \multicolumn{3}{|c|}{ BLANKS } \\
\hline & $\begin{array}{r}\text { Bo70a4 } \\
\text { water-uf } \\
\mathrm{mo} / \mathrm{L}\end{array}$ & $\begin{array}{r}\text { B070X8 } \\
\text { dup. -uf } \\
\text { mo/L }\end{array}$ & $\begin{array}{r}\text { BO7DT2 } \\
\text { water-uf } \\
\mathrm{mg} / \mathrm{L}\end{array}$ & $\begin{array}{r}\text { BO7DT4 } \\
\text { water-uf } \\
\mathrm{mg} / \mathrm{L}\end{array}$ & $\begin{array}{c}\text { Bo70T6 } \\
\text { water-uf } \\
\mathrm{mg} / \mathrm{L}\end{array}$ & $\begin{array}{r}\text { B070T8 } \\
\text { water-uf } \\
\mathrm{mg} / \mathrm{L}\end{array}$ & $\begin{array}{r}\text { Bo7Dvo } \\
\text { water-uf } \\
\mathrm{mg} / \mathrm{L}\end{array}$ & $\begin{array}{r}\text { BO7DYo } \\
\text { full blk } \\
\mathrm{mg} / \mathrm{L} \\
\end{array}$ & $\begin{array}{r}8070 Y 2 \\
\text { trp b/k } \\
\mathrm{mg} / \mathrm{L}\end{array}$ & $\begin{array}{r}\text { B070Y3 } \\
\text { trp blk } \\
\mathrm{mg} / \mathrm{L}\end{array}$ \\
\hline 1.1.1-Trichloroothene & $\mathbf{u}$ & $0.0018 \mathrm{~L}$ & $\mathbf{u}$ & $0.0028 \mathrm{~L}$ & $\mathbf{u}$ & $u$ & $0.0029 \mathrm{~L}$ & $\mathbf{u}$ & $u$ & $\mathbf{u}$ \\
\hline 1.1.2-Trichloroethene & $\mathbf{u}$ & $\underline{u}$ & $\mathrm{u}$ & $u$ & $u$ & $u$ & $u$ & $u$ & $u$ & $u$ \\
\hline 1.1-Dichlorowethen & $\mathbf{u}$ & $\mathbf{u}$ & $\mathbf{u}$ & $\mathbf{u}$ & $\underline{u}$ & $u$ & $u$ & $u$ & $\mathbf{u}$ & $u$ \\
\hline 1.2-Dichlonoethens & $\mathbf{u}$ & $\underline{u}$ & $\mathbf{u}$ & $u$ & $u$ & $u$ & $u$ & $\mathbf{u}$ & $\mathbf{u}$ & u \\
\hline 1,2-Dichloroethens & $\mathbf{u}$ & u & $\mathbf{u}$ & $u$ & $u$ & $u$ & $u$ & $\mathbf{u}$ & $\mathbf{u}$ & U \\
\hline 1.4-Dichlorobenzene & $u$ & $\underline{u}$ & $u$ & $\mathrm{u}$ & $u$ & $u$ & $u$ & $u$ & $u$ & u \\
\hline 1-8utenol & $u$ & $\mathbf{u}$ & $u$ & $u$ & $\mathbf{u}$ & $u$ & $u$ & $u$ & $u$ & $\mathrm{u}$ \\
\hline 4-Mothyl-2-pentenone & $u$ & $u$ & $u$ & $u$ & $u$ & $u$ & $\mathbf{u}$ & $u$ & $u$ & $\underline{U}$ \\
\hline Acetone & $\mathbf{u}$ & $u$ & $u$ & $u$ & $\mathbf{u}$ & $u$ & $\mathbf{u}$ & $\mathbf{u}$ & $u$ & $\mathbf{u}$ \\
\hline Benzens & $u$ & $\mathbf{u}$ & $u$ & $u$ & $u$ & $u$ & $\mathbf{u}$ & $\mathbf{u}$ & $u$ & $u$ \\
\hline Centoon dieculide & $u$ & $\mathbf{u}$ & $\mathbf{u}$ & $\mathbf{u}$ & $u$ & $\mathbf{u}$ & $\mathbf{u}$ & $\mathbf{u}$ & $\mathbf{u}$ & U \\
\hline Cention tetrechloride & $u$ & $\mathbf{u}$ & $\mathbf{u}$ & $\mathbf{u}$ & $u$ & $\mathbf{u}$ & $u$ & $\mathbf{u}$ & $\mathbf{u}$ & $\mathbf{u}$ \\
\hline Chioroform & 0.0074 & 0.0069 & $u$ & $\mathbf{u}$ & $u$ & $u$ & $u$ & $\mathbf{u}$ & $\mathbf{u}$ & $u$ \\
\hline Ethrit oyenide & $u$ & $u$ & $u$ & $\mathbf{u}$ & $u$ & $u$ & $u$ & $\mathbf{u}$ & $\mathbf{u}$ & U \\
\hline Mothyl ethyl keton & $\mathbf{u}$ & $\underline{u}$ & 0.05 & $\mathbf{u}$ & $\mathbf{u}$ & $\mathbf{u}$ & 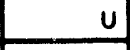 & $\mathbf{u}$ & $u$ & u \\
\hline Mothybene chloride. & $\mathbf{u}$ & $u$ & $\mathbf{u}$ & $u$ & $u$ & $u$ & $u$ & $\mathbf{u}$ & $u$ & $\mathbf{u}$ \\
\hline Tetrechloresthene & $\mathbf{u}$ & $\mathbf{u}$ & $\mathbf{u}$ & $\mathbf{u}$ & $\mathbf{u}$ & $\mathbf{u}$ & $u$ & $\mathbf{u}$ & $\mathbf{u}$ & $\mathbf{U}$ \\
\hline Totrenydofuren & ua & $0.007 \mathrm{LQ}$ & 0.042 & 0.018 & 0.011 & $0.0084 \mathrm{~L}$ & $0.0074 \mathrm{~L}$ & $\mathbf{u}$ & $u$ & $\mathbf{U}$ \\
\hline Toluenese & $\mathbf{u}$ & $\mathbf{u}$ & $u$ & $u$ & $u$ & $\mathbf{u}$ & $\mathbf{u}$ & $\mathbf{U}$ & $u$ & $\mathbf{U}$ \\
\hline Trichlorocthene & $\mathbf{u}$ & $\mathbf{u}$ & 0.00002 & $u$ & $u$ & $u$ & $u$ & $\mathbf{u}$ & $u$ & $u$ \\
\hline Vinvl chboride & $\mathbf{u}$ & $u$ & $u$ & $\mathbf{u}$ & $\mathbf{u}$ & $u$ & $u$ & $\mathbf{U}$ & $u$ & $U$ \\
\hline Xybenes fwotull & $\mathbf{u}$ & $\mathbf{u}$ & $\mathbf{u}$ & $\mathbf{u}$ & $\mathbf{u}$ & $u$ & $\mathbf{u}$ & $\mathbf{U}$ & $\mathbf{u}$ & U \\
\hline
\end{tabular}

Uannotyzed for but undetected

Q $=$ Dota can be used qualitatively

uf $=$ unfil tered

$f=f i l$ tered $(0.2 \mu)$ 
DOE/RL-93-96, Rev. 0

\begin{tabular}{|c|c|c|c|c|}
\hline \multicolumn{5}{|c|}{$\begin{array}{l}\text { TEST *2 SOIL WASHING RESULTS } \\
\text { TRIP BLANKS }\end{array}$} \\
\hline & \multicolumn{4}{|c|}{ SEPTEMBER 1993 PROCESSING } \\
\hline & $\begin{array}{r}\text { BO70Y5 } \\
\text { soil } \\
\mathrm{mg} / \mathrm{kg}\end{array}$ & $\begin{array}{r}\text { BO7DY6 } \\
\text { soil } \\
\mathrm{mg} / \mathrm{kg}\end{array}$ & $\begin{array}{c}\text { BO7DYo } \\
\text { water } \\
\mathrm{mg} / \mathrm{L}\end{array}$ & $\begin{array}{c}\text { BO7DY1 } \\
\text { water } \\
\mathrm{mg} / \mathrm{L}\end{array}$ \\
\hline$A_{0}$ & $\mathbf{u}$ & U & $0.0034 \mathrm{~L}$ & $0.0029 \mathrm{~L}$ \\
\hline Al & $69 \mathrm{Q}$ & 800 & $u$ & $u$ \\
\hline B. & $0.28<Q$ & $0.33 \mathrm{LQ}$ & $0.00023 \mathrm{LQ}$ & $0.00046 \mathrm{LQ}$ \\
\hline Be & $\mathbf{u}$ & $\mathbf{u}$ & $u$ & $\mathbf{u}$ \\
\hline C. & 140 & 140 & $0.039 \mathrm{~L}$ & $0.03 \mathrm{~L}$ \\
\hline cd & $\mathbf{u}$ & $\mathbf{u}$ & $u$ & $u$ \\
\hline Co & $\mathbf{u}$ & $\mathbf{u}$ & $u$ & $0.0063 \mathrm{~L}$ \\
\hline $\mathrm{Cr}$ & $\mathbf{u}$ & $\mathbf{u}$ & $u$ & u \\
\hline Cu & $1.1 \mathrm{~L}$ & $u$ & $u$ & u \\
\hline Fo & $140 \mathrm{Q}$ & $150 a$ & $u$ & $u$ \\
\hline Ho & $u$ & $u$ & $u$ & $u$ \\
\hline$k$ & $51 \mathrm{~L}$ & $\mathbf{u}$ & $0.88 \mathrm{~L}$ & $0.82 \mathrm{~L}$ \\
\hline Mo & $7.2 \mathrm{LQ}$ & $6.9 \mathrm{La}$ & $u$ & $\mathbf{u}$ \\
\hline Mn & $0.67 \mathrm{LQ}$ & $0.38<0$ & $u$ & $U$ \\
\hline Na & $u$ & $25 \mathrm{~L}$ & $u$ & U \\
\hline Ni & $u$ & $u$ & $u$ & U \\
\hline Po & $u$ & $\dot{U}$ & $0.0031 \mathrm{~L}$ & $0.0007 \mathrm{~L}$ \\
\hline Sb & $\mathbf{u}$ & $\mathbf{u}$ & $u$ & $\mathbf{u}$ \\
\hline sn & $u$ & $\mathbf{u}$ & $u$ & $\mathbf{u}$ \\
\hline$v$ & $u$ & $0.64 \mathrm{~L}$ & $\mathbf{u}$ & $\mathbf{u}$ \\
\hline $2 n$ & $0.63 \mathrm{~L}$ & $0.7 \mathrm{~L}$ & $\mathbf{u}$ & $\mathbf{u}$ \\
\hline & $\mathrm{pCl} / \mathrm{g}$ & $\mathrm{pCl} / \mathrm{o}$ & $\mathrm{pCi} / \mathrm{L}$ & $\mathrm{pCl} / \mathrm{L}$ \\
\hline$C 0-60$ & $-0.000 u$ & $-0.006 U$ & $.6 .94 U$ & $4.51 \mathrm{U}$ \\
\hline Cs-137 & $0.012 U$ & $-0.01 U$ & $2.29 \mathrm{U}$ & $1.55 \mathrm{U}$ \\
\hline $\mathrm{Pb}-212$ & 0.0765 & 0.0852 & $16.7 U$ & 44.5 \\
\hline $\mathrm{Pb}-214$ & 0.115 & 0.0949 & $4.41 \mathrm{U}$ & $-0.157 U$ \\
\hline$R=-224$ & 0.077 & 0.0858 & & \\
\hline$R=-226$ & 0.151 & 0.0917 & & \\
\hline Ru-108 & $-0.002 U$ & $0.004 U$ & & \\
\hline $5 b-125$ & $-0.042 \mathrm{U}$ & $0.016 U$ & & \\
\hline & $\mathrm{pCl} / \mathrm{e}$ & $\mathrm{pCl} / \mathrm{a}$ & $\omega g / L$ & noll \\
\hline U-Net & $-0.232 U$ & $-0.187 U$ & $0.0675 U$ & $0.0713 U$ \\
\hline & $\mathbf{m g} / \mathbf{k g}$ & mo/ko & $\mathbf{m g} / \mathrm{L}$ & $\mathrm{mo} / \mathrm{L}$ \\
\hline Areelor-1010 & $\mathbf{u}$ & $\mathbf{u}$ & $u$ & $u$ \\
\hline Aroctor-1221 & $\mathbf{u}$ & $u$ & $\mathbf{u}$ & $U$ \\
\hline Aroobor-1 232 & $\mathbf{u}$ & $\mathbf{u}$ & $\mathbf{u}$ & U \\
\hline Aroctor-1242 & $u$ & $\mathbf{u}$ & $\mathbf{u}$ & $u$ \\
\hline Aroclor-1248 & $u$ & $\mathbf{u}$ & $u$ & $\mathbf{u}$ \\
\hline Aroclor-1 254 & $u$ & $\mathbf{u}$ & $\mathbf{u}$ & $u$ \\
\hline Arocior-1260 & $\mathbf{u}$ & $u$ & $\mathbf{u}$ & $\mathbf{u}$ \\
\hline
\end{tabular}

Unanalyzed for but undetected

Qmasa can be used qualitatively

\section{B. $2-10$}


DOE/RL-93-96, Rev. 0

recefreds 09/13/93 ixa ine.

Results by saeple

semple Matrix (soillwate:: : Sell Leachaee rol enalyzed (mL), 1 ones roceired og/13/93 onte Anelyzed: 0o/12/93 inserumene 10: vivele
Lob file 10: 30997m08

relp Extraction oute: 22/15/23 oece Leochara Extraceca:

ollution is:sor:

\begin{tabular}{|c|c|c|c|}
\hline cas no. & - GOKPOUKO & $\begin{array}{l}\text { REsult } \\
\text { (mg/l) }\end{array}$ & $\begin{array}{l}P Q L \\
(m g / L)\end{array}$ \\
\hline $79-63 \cdot 2$ & Benzene & no & 0.025 \\
\hline $36 \cdot 23 \cdot 5$ & earbon Tetrachlorlde & ND & 0.025 \\
\hline $108 \cdot 90 \cdot 7$ & Chlorobenzene & ND & 0.025 \\
\hline $67 \cdot 66 \cdot 3$ & encoroform & No & 0.025 \\
\hline $107 \cdot 06 \cdot 2$ & 1,2-oienloroeshane & no & 0.025 \\
\hline $75 \cdot 35 \cdot 6$ & 1,9-olehloroethylene & ND & 0.025 \\
\hline $98 \cdot 93 \cdot 3$ & Methyl Eenyl Retone & No & 0.050 \\
\hline $127 \cdot 18 \cdot 6$ & Peerechloroethylene & no & 0.025 \\
\hline $79.01 \cdot 6$ & Irlehloroethylene & ND & 0.025 \\
\hline $75-01 \cdot 6$ & vingl entoride & No & 0.050 \\
\hline
\end{tabular}

z recoverat sureooate conpound

\author{
de-rolvene 25 \\ Sponefluorobenzens \\ 95 \\ 1.2-olehtoroethone-as \\ 29 \\ PORM 1
}



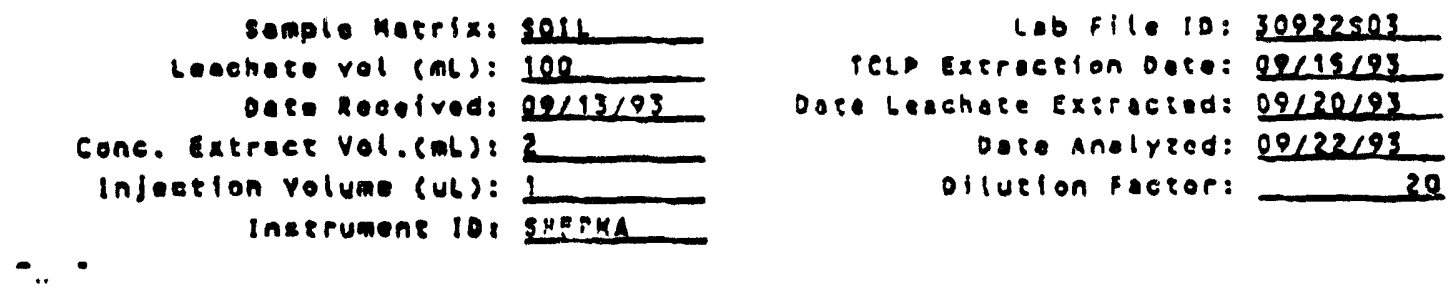

\begin{tabular}{|c|c|c|c|}
\hline cas Mo. & COMPOUND & $\begin{array}{l}\text { RESULP } \\
(n g / 6)\end{array}$ & $\begin{array}{c}D S L \\
\text { (Ae/l) }\end{array}$ \\
\hline $1319 \cdot 77 \cdot 3$ & :iesol (Total) & no & 0.1 \\
\hline $87 \cdot 86 \cdot 5$ & - enzechl oraphenol & no & 0.5 \\
\hline $98-93: 6$ & 2.6.5-Priehlorophenol & No & 0.1 \\
\hline $86-06 \cdot 2$ & 2.6.6-iriehlorephenol & no & 0.1 \\
\hline $106 \cdot 66 \cdot 7$ & 1.6 .0 lehl orobenzene & no & 0.1 \\
\hline $121 \cdot 16 \cdot 2$ & 2,6-0inlerosoluene & no & 0.1 \\
\hline $118 \cdot 76 \cdot 1$ & Hexsehtorobenzene & no & 0.1 \\
\hline $87 \cdot 68 \cdot 3$ & Mexaenl eroburad one & no & 0.1 \\
\hline $68 \cdot 72 \cdot 1$ & Mexechioroethene & No & 0.1 \\
\hline $98 \cdot 95 \cdot 3$ & Wrerosenzene & no & 0.1 \\
\hline $110 \cdot 06 \cdot 1$ & preidine & no & 0.2 \\
\hline
\end{tabular}

* escover surnogate cokpouno

2- ll vorephenel

ohenol-ds

2,6,6-1plbromedienal

Nierobenzene-ds

2- Bluerobiohenyl

Perphenyl-a16

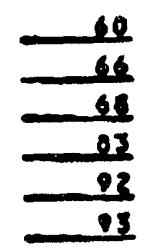

$\operatorname{son} 1$

B. 2-12 
DOE/RL-93-96, Rev. 0

\begin{tabular}{|c|c|c|c|}
\hline cas no. & CONPOUHO & $\begin{array}{l}\text { RESULt } \\
\text { (ng/L) }\end{array}$ & $\begin{array}{c}P Q L \\
(m g / 6)\end{array}$ \\
\hline$\cdot 57 \cdot 76 \cdot 9$ & Chlordene & nO & 0.005 \\
\hline $72 \cdot 20 \cdot 8$ & endeln & wo & 0.001 \\
\hline $76-66 \cdot 8$ & neprachlor & no & 0.0005 \\
\hline $1026 \cdot 37 \cdot 3$ & nepteenlor Epoxlde & No & 0.0005 \\
\hline $38 \cdot 09 \cdot 9$ & cindene & no & 0.0003 \\
\hline $12 \cdot 43 \cdot 5$ & Metnoxychlor & no & 0.005 \\
\hline $8001 \cdot 35 \cdot 2$ & rexaphene & No & 0.020 \\
\hline
\end{tabular}

\section{* recoverer suraocate compound}

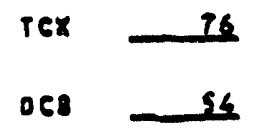




$$
\text { DOE/RL-93-96, Rev. } 0
$$
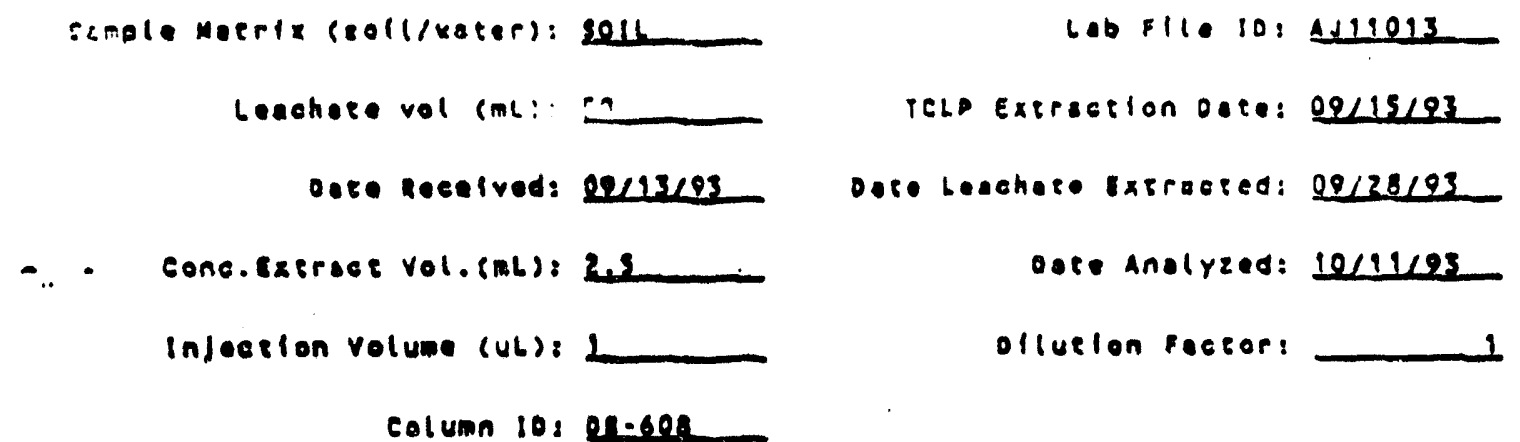

column 102 01.608

\begin{tabular}{|c|c|c|c|}
\hline cas Ho. & conpouno & $\begin{array}{l}\text { nesult } \\
\text { (nes) }\end{array}$ & $\begin{array}{c}P Q L \\
(m o / L)\end{array}$ \\
\hline $96 \cdot 75 \cdot 7$ & $2,6 \cdot 0$ & No & 0.01 \\
\hline $93 \cdot 72 \cdot 1$ & $2,6,5 \cdot T P$ & no & 0.001 \\
\hline
\end{tabular}

I Recovery suRroonte conpouno

DCAA

29

poan 1 
DOE/RL-93-96, Rev. 0

rua tne.

REPORT

Results by seaple

Vork order 13.09 .023

\footnotetext{
- eoeolvedr 09:?:!93
}

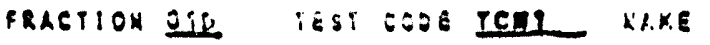

oece rime collected pelog/93

reLP MEIALS

Simple Matriz: 2011

icto exeraction Dase: 02/15/23

onte Recelveds $22413 / 23$

\begin{tabular}{|c|c|c|c|c|}
\hline CAS MO. & conPOUNO & $\begin{array}{l}\text { nesubt } \\
\text { (ne/t) }\end{array}$ & $\begin{array}{c}006 \\
(00 / 6)\end{array}$ & METHOD \\
\hline $7660-38 \cdot 2$ & arsente & 0.003 & 0.001 & p \\
\hline $7660 \cdot 39 \cdot 3$ & Ber!:-: & 2.65 & 0.001 & p \\
\hline $7660.63-9$ & cadnitun & 0.008 & 0.007 & $p$ \\
\hline $7660.67-3$ & Ehroelun & 0.057 & 0.006 & $p$ \\
\hline 7630.92 .1 & leed & 0.019 & 0.001 & $F$ \\
\hline $7439 \cdot 97.6$ & Mereury & 0.0030 & 0.0002 & ev \\
\hline $7782 \cdot 69 \cdot 2$ & sereniug & no & 0.002 & r \\
\hline $7660-22.6$ & sliver & 0.07 & 0.01 & a \\
\hline
\end{tabular}

anolyeleal mochode Uoeds
- Iep
A. Flone in
P Purnoge Aa
CV - Cold vapor aA

PORN 1 
From: Geochemistry \& Hydrochemistry

Phone: $376-3324$

Date: $\quad$ December 1, 1993

Subject: DATA VALIDATION OF 300-FF-1 SOIL WASHING COLLECTED SEPTEMBER 1993

To: R. D. Belden
cC: J. C. Johnston
D. G. Horton

This report is to document the validation of $300-F F-1$ Soil Washing data collected during September 1993. The validation was based on WHC-CM-7-8 manual "Environmental Engineering and Geotechnology Function Procedures" (WHC 1992) and the "Annual Report for RCRA Groundwater Monitoring Projects at Hanford Site Facilities for 1992" Appendix B DOE/RL-93-09 (DOE-RL, 1993a).

The data were collected, analyzed and processed in a similar manner as the Resource Conservation and Recovery Act (RCRA) groundwater monitoring projects. The analytical laboratories utilized were Datachem Laboratory, Salt Lake City Utah and International Technology Analytical Services, Richland, Washington. Data validation was performed by Ms. P.B. Freeman, RCRA Sampling and Analysis Task Leader. A electronic copy of the data is provide in both paradox and lotus format. Hardcopies of data were provided prior to this report.

Data validation consisted of seven parts:

a. $100 \%$ verification that requested data were received.

b. $100 \%$ verification that holding times were meet.

c. 100\% evaluation of precision with field duplicates

d. 100\% evaluation of potential sample contamination with field blank data.

e. $100 \%$ evaluation of laboratory MS/MSD and surrogate data through laboratory incident reports.

f. $100 \%$ evaluation of laboratory blanks.

g. $100 \%$ evaluation of data completeness.

The outcome of the validation:

Part a: All data requested were received.

Part b: All analytical holding times were meet.

Part c:

Evaluation of Duplicate data was performed using procedure 2.1 "Evaluation of RCRA Groundwater Field Duplicate and Blank Sample Data" (WHC 1992) and using Appendix B (DOE-RL 1993). 
There were two duplicate pairs evaluated. The paired sample numbers are B070X9 with B07DQ5 and B070X8 with B07DQ4, respectfully. The evaluation of $8070 \times 9$ and $B 07005$ resulted in three constituents which exceeded a required $25 \%$ relative percentage difference (WHC 1992) and were above the limit of detection as defined in Appendix B (DOE-RL 1993). The three constituents are copper, potassium and silver. All of these were analyzed by ICP metal method SW-846 6010 .

The evaluation of $B 070 \times 8$ and $B 070 Q 4$ resulted in twelve constituents which exceeded a required $25 \%$ relative

percentage difference (WHC 1992) and were above the limit of detection as defined in Appendix B (DOE-RL 1993). The twelve constituents are: total uranium, tetrahydrofuran, barium, calcium, copper, magnesium, manganese, potassium, silver, sodium, zinc and lead. Urantum was analyzed by an inhouse method. Tetrahydrofuran was analyzed by method SW8468240 . Lead was analyzed by method SW-846 7421 and the rest were analyzed by method SW-846 6010 .

As a result of this evaluation all data associated with these sample numbers and const tuents are flagged with a validation flag of $Q$. The Q-flagged data can be used qualitatively, but not regulatory decisions should be made based on a single flagged data point.

Part d: Evaluation of field blank data was performed using procedure 2.1 "Evaluation of RCRA Groundwater Fleld Duplicate and Blank Sample Data" (WHC 1992) and using Append $X$ B (DOE-RL 1993).

There were two water blanks and two soil blanks collected during the September 1993 sampling. The blanks exceeding two times the method detection limit (MDL) were flagged with a $Q$ (WHC 1992). MDL are defined in Appendix B (DOE-RL 1993). The sample numbers for the water blanks are BO70YO and BOTDY1. Each sample had one the same constituent exceed two times the MDL. The constituent was barium which is analyzed by method SW-846 6010. The sample numbers for the soll blanks are BO7DY5 and B07DY6. Each sample had the same six constituents exceed two times the MDL. The constituents were aluminum, iron, magnesium, manganese, barium and calclum. These constituents were analyzed by method SW-846 6010 .

As a result of this evaluation the above constituents associated with the collect and analyze dates of these sample numbers and constituents are flagged with a validation $f 1$ ag of $Q$. The $Q$-flagged data can be used qualitatively, but not regulatory decisions should be made based on a single flagged data point.

Part e: There were not laboratory incident reports for this data. Therefore, no matrix spike, matrix spike duplicate or surrogate samples assoclated with these samples exceeded laboratory acceptance criteria. 
Part f: There were no " $B$ " qualifiers associated with these data, therefore no laboratory blanks exceeded laboratory acceptance criteria.

Part g: The data completeness is determined after data validation is completed and is calculated by the number of unflagged divided by the total number of validated data expressed as a percentage. The RCRA using a $80 \%$ acceptance guidance. The total number of soll data are 1122 constituents and water data are 683 constituents. The total unflagged soll data are 918 constituents and water data are 639 constituents. The calculated completeness for sotl and water data are $82 \%$ and $93 \%$, respectfully. These data are within acceptable completeness criteria.

References:

DOE-RL, 1993, Annual Report for RCRA Groundwater monitoring Projects at Hanford Site Facilities for 1992, DOE/RL93-09, U.S. Department of Energy, Richland Operations Office, Richland, Washington.

WHC, 1992, Environmental Engineering and Geotechnology Function Procedures, WHC-CM-78, vol. 4, West inghouse Hanford Company, Richland, Washington.

P. B. Freeman

RCRA Sampling and Analysis Task Team Leader

pbf 
DOE/RL-93-96, Rev. 0

B.3 ANALYTICAL DATA FOR WATER TREATMENT

B.3-1 
DOE/RL-93-96, ReV. 0

DATA QUALIFIERS FOR ANALYTICAL DATA

FOR WATER TREATMENT SAMPLES

$U$ Indicates that this constituent was analyzed for but undetected.

$\mathbf{p}$

Indicates there is greater than 25\% difference for detected concentrations between the two Gas Chromatagraph columns. The lower value is reported.

Indicates the result reported is below the contract quantitation 1 imit. 
DOE/RL-93-96, Rev. 0

\begin{tabular}{|c|c|c|c|c|c|c|c|c|c|c|}
\hline \multirow[b]{3}{*}{ Const i tuents } & \multirow{2}{*}{\multicolumn{7}{|c|}{$\begin{array}{l}\text { WATER TREATMENT RESULTS } \\
\\
\text { Effluent }\end{array}$}} & \multirow{2}{*}{\multicolumn{3}{|c|}{ Irip Blanks }} \\
\hline & & & & & & & & & & \\
\hline & $\begin{array}{r}\text { B098R4 } \\
\text { water } \\
\text { ar: } / \mathrm{L} \\
\end{array}$ & $\begin{array}{r}\text { 8098R6 } \\
\text { water } \\
\mathrm{m} / \mathrm{L} \\
\end{array}$ & $\begin{array}{r}\text { Bo98R7 } \\
\text { water } \\
\text { modL } \\
\end{array}$ & $\begin{array}{r}\text { B098R5 } \\
\text { water } \\
\mathrm{mo} / 1 \\
\end{array}$ & $\begin{array}{r}\text { B098R8 } \\
\text { water } \\
\mathrm{mg} / \mathrm{L} \\
\end{array}$ & $\begin{array}{r}\text { B09BR9 } \\
\text { water } \\
\mathrm{mg} / \mathrm{i} \\
\end{array}$ & $\begin{array}{r}\text { BogBso } \\
\text { dup. } \\
\mathrm{mg} / \mathrm{L} \\
\end{array}$ & $\begin{array}{r}\text { B098w2 } \\
\text { water } \\
\mathrm{mg} / \mathrm{L} \\
\end{array}$ & $\begin{array}{r}\text { B09BWS } \\
\text { water } \\
\mathrm{mg} / \mathrm{L} \\
\end{array}$ & $\begin{array}{r}\text { B09Bw8 } \\
\text { water } \\
\mathrm{mg} / \mathrm{L} \\
\end{array}$ \\
\hline$A s$ & 0.005 & 0.0037 & 0.0056 & 0.005 & 0.0037 & 0.0037 & 0.0037 & $N / A$ & N/A & H/A \\
\hline Al & 1,340 & 0.0422 & 0.291 & 0.155 & 0.104 & 0.103 & 0.078 & $N / A$ & N/A & $N / A$ \\
\hline An & 0.0021 & 0.0022 & 0.0046 & 0.0021 & 0.0021 & 0.0022 & 0.0021 & $N / A$ & $N / A$ & $N / A$ \\
\hline 8 & 0.0873 & 0.061 & 0.0698 & 0.0629 & 0.0343 & 0.0533 & 0.0533 & N/A & N/A & $N / A$ \\
\hline Be & 0.0002 & 0.0002 & 0.0002 & 0.0002 & 0.0002 & 0.0002 & 0.0002 & $N / A$ & $N / A$ & $N / A$ \\
\hline Ga. & 19.3 & 19.8 & 20.7 & 19.5 & 2.79 & 15.5 & 15,1 & $N / A$ & $N / A$ & $N / A$ \\
\hline cd & 0.001 & 0.0026 & 0.001 & 0.001 & 0.001 & 0.0019 & 0.0016 & N/A & $N / A$ & $N / A$ \\
\hline Co & 0.003 & 0.003 & 0.003 & 0.003 & 0.003 & 0.003 & 0.003 & $N / A$ & $N / A$ & $N / A$ \\
\hline $\mathrm{Cr}$ & 0.0061 & 0.0041 & 0.0077 & 0.0041 & 0.0041 & 0.0041 & 0.0041 & $N / A$ & $N / A$ & $N / A$ \\
\hline $\mathrm{Cu}$ & 0.345 & 0.013 & 0.252 & 0.160 & 0.0131 & 0.0389 & 0.0361 & $N / A$ & $N / A$ & $N / A$ \\
\hline fe. & 42.1 & 0.569 & 47.8 & 41.4 & 0.762 & 4.52 & 3.33 & $N / A$ & $N / A$ & $N / A$ \\
\hline $\mathrm{Ha}$ & 0.0003 & 0.0002 & 0.0002 & 0,0002 & 0.0002 & 0.0002 & 0.0002 & $N / A$ & $M / A$ & $N / A$ \\
\hline$k$ & 1.84 & 1.68 & 1.86 & 1.77 & 1.9 & 1.67 & 1.71 & $N / A$ & $N / A$ & $N / A$ \\
\hline$M$ & $4 . \pi$ & 6.69 & 4.62 & 4.43 & 3.02 & 3.82 & 3.74 & $N / A$ & $\mathrm{~N} / \mathrm{A}$ & N/A \\
\hline$m$ & 0.22 & 0.0832 & 0.269 & 0.218 & 0.0157 & 0.121 & 0.118 & $N / A$ & $N / A$ & $N / A$ \\
\hline $\mathrm{Me}$ & 21.9 & 22.7 & 22.4 & 22.0 & 38.2 & 29.7 & 29.0 & $N / A$ & $N / A$ & $N / A$ \\
\hline$M 1$ & 0.0443 & 0.0119 & 0.0344 & 0.0272 & 0.0039 & 0.0136 & 0.0126 & $n / A$ & $N / A$ & $N / A$ \\
\hline$P b$ & 0.216 & $0.006 \mathrm{~K}$ & 0.0628 & 0.0562 & 0.0063 & 0.0066 & 0.0048 & $N / A$ & $N / A$ & $N / A$ \\
\hline sto & 0.023 & 0.0218 & 0.0123 & 0.0292 & 0.0092 & 0.0092 & 0.0092 & $M / A$ & $N / A$ & $N / A$ \\
\hline 8 & 0.0021 & 0.0028 & 0.0028 & 0.0028 & 0,0028 & 0.0028 & 0.0028 & $M / A$ & $\mathbf{N} / \mathbf{A}$ & $N / A$ \\
\hline II & 0.0016 & 0.0028 & 0.0016 & 0.0016 & 0.0016 & 0.0021 & 0.0023 & $N / A$ & $N / A$ & $N / A$ \\
\hline$y$ & 0.006 & 0.0026 & 0.0032 & 0.0026 & 0.0026 & 0.0026 & 0.0026 & N/A & $N / A$ & $N / A$ \\
\hline $2 n$ & 1.22 & 0.199 & 1.2 & 1.72 & 0.0839 & 0.232 & 0.353 & N/A & N/A & $N / A$ \\
\hline
\end{tabular}

N/A - Analysis is Not Applicable for Trip Blanks 
DOE/RL-93-96, Rev. 0

\begin{tabular}{|c|c|c|c|c|c|c|c|c|c|c|}
\hline \multirow[b]{2}{*}{ Const i tuents } & \multicolumn{3}{|c|}{ Influen: } & \multicolumn{4}{|c|}{ Effluent } & \multicolumn{3}{|c|}{ Irip Blanks } \\
\hline & $\begin{array}{r}8098 R 4 \\
\text { water } \\
\text { oci/L }\end{array}$ & $\begin{array}{c}\text { 8098R6 } \\
\text { water } \\
\text { oci/L }\end{array}$ & $\begin{array}{c}\text { 8098R7 } \\
\text { water } \\
\text { ocild }\end{array}$ & $\begin{array}{l}\text { B098R5 } \\
\text { water } \\
\text { pci/1 }\end{array}$ & $\begin{array}{l}\text { B098R8 } \\
\text { water } \\
\text { pCi/L }\end{array}$ & $\begin{array}{r}\text { B098R9 } \\
\text { water } \\
\text { oci } / 4\end{array}$ & $\begin{array}{r}\text { B098so } \\
\text { dup. } \\
\text { oci } / 4\end{array}$ & $\begin{array}{c}\text { B09BW2 } \\
\text { water } \\
\text { PCi/L }\end{array}$ & $\begin{array}{l}\text { Bo9Bus } \\
\text { water } \\
\text { pCi/L }\end{array}$ & $\begin{array}{l}\text { B098w8 } \\
\text { water } \\
\text { pCi/L }\end{array}$ \\
\hline $22 \mathrm{Ma}$ & $u$ & $u$ & $u$ & $u$ & $u$ & $u$ & $u$ & $N / A$ & $N / A$ & $N / A$ \\
\hline $40 k$ & u & u & $y$ & v & $u$ & $u$ & $y$ & $M / A$ & N/A & N/A \\
\hline 54 & $y$ & $y$ & $u$ & $u$ & $u$ & $u$ & $u$ & $N / A$ & $N / A$ & $N / A$ \\
\hline ss & $u$ & $u$ & $u$ & u & $u$ & $u$ & $u$ & $N / A$ & $N / A$ & $N / A$ \\
\hline 38 & $u$ & 4 & $u$ & $u$ & $u$ & $u$ & $u$ & $N / A$ & $N / A$ & $N / A$ \\
\hline${ }^{60} \mathrm{co}$ & $u$ & 4 & $u$ & $u$ & $u$ & $u$ & $u$ & $N / A$ & $N / A$ & $N / A$ \\
\hline $9 / 4$ & $y$ & $u$ & $u$ & 4 & $u$ & $u$ & $y$ & $M / A$ & $N / A$ & $N / A$ \\
\hline 1 & $u$ & $u$ & $u$ & $u$ & $u$ & $u$ & $u$ & $N / A$ & $N / A$ & N/A \\
\hline$\underline{u}$ & $u$ & $u$ & $u$ & $u$ & $u$ & $u$ & $u$ & $N / A$ & $N / A$ & $N / A$ \\
\hline & U & $u$ & $u$ & $y$ & $u$ & $u$ & $y$ & $N / A$ & $N / A$ & $N / A$ \\
\hline & $u$ & $u$ & $y$ & $\underline{u}$ & $u$ & $u$ & $u$ & $N / A$ & $N / A$ & $N / A$ \\
\hline $137_{\mathrm{Cs}}$ & $u$ & $u$ & $u$ & $u$ & 9.1 & $u$ & $u$ & $N / A$ & $N / A$ & $N / A$ \\
\hline & $u$ & $u$ & $u$ & $u$ & $u$ & $u$ & $u$ & $N / A$ & $N / A$ & $N / A$ \\
\hline 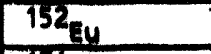 & $u$ & $u$ & $u$ & $u$ & $u$ & $u$ & $u$ & $N / A$ & $N / A$ & M/A \\
\hline 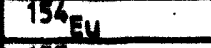 & $u$ & 4 & $y$ & U & $u$ & $u$ & $u$ & $\mathbf{N} / \mathbf{A}$ & $\mathbf{M} / \mathbf{A}$ & $M / A$ \\
\hline & $u$ & $u$ & $u$ & $y$ & $u$ & $u$ & $u$ & $N / A$ & $M / A$ & $N / A$ \\
\hline 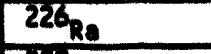 & $u$ & $u$ & $u$ & $u$ & $u$ & $u$ & $\underline{u}$ & $N / A$ & $N / A$ & $N / A$ \\
\hline- & 4 & $u$ & $u$ & $y$ & $\mu$ & 4 & $y$ & $\mathbf{M} / \mathbf{A}$ & $M / A$ & $\mathrm{~N} / \mathrm{A}$ \\
\hline & $u$ & $u$ & $u$ & $u$ & $u$ & $u$ & $y$ & $N / A$ & $N / A$ & $M / A$ \\
\hline $23 \mathrm{Th}^{2}$ & $u$ & $u$ & $u$ & $u$ & $u$ & $u$ & $u$ & $N / A$ & $N / A$ & $N / A$ \\
\hline 2364 & 2000 & MNP & 1500 & 1400 & 900 & 5800 & 460 & $N / A$ & $N / A$ & $N / A$ \\
\hline
\end{tabular}

$U$ - Analyzed for but undetected

M/A - Analysis is Not Applicable for Trip Blanks

ANP - Analysis was Not Possible due to semple size 
DOE/RL-93-96, Rev. 0

\begin{tabular}{|c|c|c|c|c|c|c|c|c|c|c|}
\hline \multirow[b]{3}{*}{ Constituents } & \multicolumn{7}{|c|}{ WATER TREATMENT RESULTS } & \multirow{2}{*}{\multicolumn{3}{|c|}{ Trip Blanks }} \\
\hline & \multicolumn{3}{|c|}{ Influent } & \multicolumn{4}{|c|}{ Effluent } & & & \\
\hline & $\begin{array}{r}\text { B098R4 } \\
\text { water } \\
\mathrm{mg} / \mathrm{L} \\
\end{array}$ & $\begin{array}{r}\text { B098R6 } \\
\text { water } \\
\mathrm{mg} / \mathrm{L} \\
\end{array}$ & $\begin{array}{r}\text { B098R7 } \\
\text { water } \\
\mathrm{mg} / \mathrm{L} \\
\end{array}$ & $\begin{array}{r}\text { B09BR5 } \\
\text { water } \\
\mathrm{mg} / 1 \\
\end{array}$ & $\begin{array}{r}\text { B09BR8 } \\
\text { water } \\
\text { mg/L }\end{array}$ & $\begin{array}{r}\text { B09BR9 } \\
\text { water } \\
\mathrm{mg} / \mathrm{L} \\
\end{array}$ & $\begin{array}{c}\text { B09850 } \\
\text { dup. } \\
\mathrm{mg} / \mathrm{L}\end{array}$ & $\begin{array}{r}\text { B09BW2 } \\
\text { water } \\
\mathrm{mg} / \mathrm{L}\end{array}$ & $\begin{array}{r}\text { B098w5 } \\
\text { water } \\
\mathrm{mg} / \mathrm{L} \\
\end{array}$ & $\begin{array}{r}\text { B098w8 } \\
\text { water } \\
\mathrm{mg} / \mathrm{L} \\
\end{array}$ \\
\hline Chloromethane & $0.01 \mathrm{U}$ & $0.01 \mathrm{U}$ & $0.01 \mathrm{U}$ & $0.01 U$ & $0.01 \mathrm{U}$ & $0.01 \mathrm{U}$ & $0.01 U$ & $0.01 \mathrm{U}$ & $0.01 \mathrm{U}$ & $0.01 \mathrm{U}$ \\
\hline Bromowethene & $0.01 \mathrm{U}$ & $0.01 \mathrm{U}$ & $0.01 \mathrm{U}$ & $0.01 \mathrm{U}$ & $0.01 U$ & $0.01 \mathrm{U}$ & $0.01 \mathrm{U}$ & $0.01 \mathrm{U}$ & $0.01 \mathrm{U}$ & $0.01 \mathrm{U}$ \\
\hline Vimyl chloride & $0.01 \mathrm{U}$ & $0.01 \mathrm{u}$ & $0.01 \mathrm{U}$ & $0.01 \mathrm{U}$ & $0.01 \mathrm{U}$ & $0.01 \mathrm{U}$ & $0.01 \mathrm{U}$ & $0.01 \mathrm{U}$ & $0.01 \mathrm{U}$ & $0.01 \mathrm{U}$ \\
\hline Chloroethene & $0.01 \mathrm{u}$ & $0.01 \mathrm{U}$ & 0.010 & $0.01 \mathrm{U}$ & $0.01 \mathrm{U}$ & $0.01 \mathrm{U}$ & $0.01 \mathrm{U}$ & $0.01 \mathrm{U}$ & $0.01 \mathrm{U}$ & 0.010 \\
\hline Methylene Chlorids & $0.01 \mathrm{U}$ & $0.01 \mathrm{u}$ & $0.01 \mathrm{U}$ & $0.01 \mathrm{U}$ & $0.01 U$ & $0.01 \mathrm{U}$ & $0.01 U$ & $0.09 \mathrm{U}$ & $0.01 \mathrm{U}$ & $0.01 \mathrm{U}$ \\
\hline Acetone & $0.01 U$ & $\begin{array}{l}0.009 \\
j\end{array}$ & $0.01 \mathrm{U}$ & $0.01 U$ & $0.01 \mathrm{U}$ & $0.01 \mathrm{U}$ & $0.01 U$ & 0.013 & 0.015 & 0.016 \\
\hline Carbon Disulfide & $0.01 U$ & $0.01 \mathrm{u}$ & $0.01 \mathrm{U}$ & $0.01 \mathrm{u}$ & $0.01 u$ & $0.01 \mathrm{U}$ & $0.01 U$ & $0.01 u$ & $0.01 U$ & $0.01 \mathrm{U}$ \\
\hline 1,1-Dichlorosthene & $0.01 \mathrm{U}$ & $0.01 \mathrm{U}$ & $0.01 \mathrm{U}$ & $0.01 U$ & $0.01 \mathrm{U}$ & $0.01 \mathrm{u}$ & $0.01 \mathrm{U}$ & $0.01 \mathrm{U}$ & $0.01 U$ & $0.01 \mathrm{U}$ \\
\hline 1,1-Dichloroethene & $0.01 \mathrm{U}$ & $0.01 u$ & $0.01 \mathrm{U}$ & $0.01 U$ & $0.01 \mathrm{U}$ & $0.01 \mathrm{U}$ & $0.01 U$ & $0.01 \mathrm{U}$ & $0.01 \mathrm{U}$ & $0.01 \mathrm{U}$ \\
\hline $\begin{array}{l}\text { 1,2-Dichloroethene } \\
\text { (total) }\end{array}$ & $0.01 U$ & $0.01 \mathrm{U}$ & $0.09 \mathrm{U}$ & $0.01 U$ & $0.01 \mathrm{U}$ & $0.01 \mathrm{U}$ & $0.01 \mathrm{U}$ & $0.01 \mathrm{U}$ & $0.01 \mathrm{U}$ & $0.01 u$ \\
\hline Chloroform & $0.01 \mathrm{U}$ & $0.01 \mathrm{u}$ & $0.01 \mathrm{U}$ & $0.01 U$ & $0.01 \mathrm{U}$ & $0.01 \mathrm{u}$ & $0.01 \mathrm{U}$ & $0.01 \mathrm{U}$ & $0.01 \mathrm{U}$ & $0.01 \mathrm{U}$ \\
\hline 1,2-dichloroethene & $0.01 \mathrm{U}$ & 0.014 & $0.01 \mathrm{U}$ & $0.01 \mathrm{U}$ & $0.01 u$ & $0.01 \mathrm{U}$ & $0.01 \mathrm{U}$ & $0.01 \mathrm{U}$ & $0.01 \mathrm{u}$ & $0.01 \mathrm{U}$ \\
\hline 2-Butanone & $0.01 \mathrm{U}$ & $0.01 \mathrm{U}$ & $0.01 \mathrm{U}$ & $0.01 U$ & $0.01 \mathrm{U}$ & $0.01 \mathrm{U}$ & $0.01 \mathrm{U}$ & $0.01 \mathrm{U}$ & $0.01 u$ & $0.01 \mathrm{U}$ \\
\hline 1,1,1-Trichloroethene & $0.01 \mathrm{U}$ & $0.01 \mathrm{U}$ & $0.01 U$ & $0.01 U$ & $0.01 \mathrm{U}$ & $0.01 \mathrm{U}$ & $0.01 \mathrm{U}$ & $0.01 U$ & $0.01 \mathrm{U}$ & $0.01 \mathrm{U}$ \\
\hline Carbon Tetrechloride & $0.01 U$ & $0.01 \mathrm{H}$ & $0.01 \mathrm{U}$ & $0.01 U$ & $0.01 \mathrm{U}$ & $0.01 \mathrm{U}$ & $0.01^{\circ} \mathrm{u}$ & $0.01 \mathrm{U}$ & $0.01 \mathrm{U}$ & $0.01 \mathrm{U}$ \\
\hline Bromodichloramethene & $0.01 \mathrm{U}$ & $0.01 \mathrm{u}$ & $0.01 \mathrm{U}$ & $0.01 U$ & $0.01 \mathrm{U}$ & $0.01 \mathrm{U}$ & $0.01 \mathrm{U}$ & $0.01 \mathrm{U}$ & $0.01 \mathrm{U}$ & $0.01 \mathrm{U}$ \\
\hline 1.2-Dichloreprogens & $0.01 v$ & $0.01 \mathrm{y}$ & $0.01 \mathrm{U}$ & $0.01 U$ & $0.01 \mathrm{U}$ & $0.01 \mathrm{U}$ & $0.01 U$ & $0.01 \mathrm{U}$ & $0.01 \mathrm{U}$ & $0.01 \mathrm{U}$ \\
\hline cis-1,3-0ichloropropene & $0.01 \mathrm{u}$ & $0.01 \mathrm{U}$ & $0.01 \mathrm{u}$ & $0.01 \mathrm{U}$ & $0.01 \mathrm{U}$ & $0.01 \mathrm{U}$ & $0.09 u$ & $0.01 U$ & $0.01 \mathrm{u}$ & $0.01 \mathrm{u}$ \\
\hline Irichloroethene & $0.01 U$ & $0.09 \mathrm{u}$ & $0.01 \mathrm{u}$ & $0.01 U$ & $0.01 \mathrm{U}$ & $0.01 \mathrm{U}$ & $0.01 u$ & $0.01 \mathrm{U}$ & $0.01 \mathrm{U}$ & $0.01 \mathrm{U}$ \\
\hline Dibro ochloromethene & $0.01 \mathrm{u}$ & $0.01 \mathrm{u}$ & $0.01 \mathrm{U}$ & $0.01 \mathrm{U}$ & $0.01 \mathrm{U}$ & $0.01 \mathrm{u}$ & $0.01 \mathrm{u}$ & $0.01 \mathrm{U}$ & $0.01 \mathrm{U}$ & $0.01 \mathrm{U}$ \\
\hline 1,1,2,-Trichloroethene & $0.01 u$ & $0.01 \mathrm{U}$ & $0.01 \mathrm{U}$ & $0.01 \mathrm{U}$ & $0.01 \mathrm{U}$ & $0.01 \mathrm{U}$ & $0.01 \mathrm{U}$ & $0.01 \mathrm{U}$ & $0.01 \mathrm{U}$ & $0.01 \mathrm{U}$ \\
\hline Benzene & $0.01 \mathrm{U}$ & $0.01 \mathrm{U}$ & $0.01 \mathrm{U}$ & $0.01 \mathrm{U}$ & $0.01 \mathrm{U}$ & $0.01 \mathrm{U}$ & $0.01 \mathrm{U}$ & $0.01 \mathrm{U}$ & $0.01 \mathrm{U}$ & $0.01 \mathrm{U}$ \\
\hline $\begin{array}{l}\text { trans }-1,3- \\
\text { Dichloropropene }\end{array}$ & $0.01 U$ & $0.01 \mathrm{U}$ & $0.01 \mathrm{U}$ & $0.01 U$ & $0.01 \mathrm{U}$ & $0.01 \mathrm{U}$ & $0.01 U$ & $0.01 U$ & $0.01 U$ & $0.01 U$ \\
\hline Bramoform & $0.01 u$ & $0.01 \mathrm{U}$ & $0.01 \mathrm{U}$ & $0.01 \mathrm{U}$ & $0.01 \mathrm{U}$ & $0.01 \mathrm{U}$ & $0.01 \mathrm{U}$ & $0.01 \mathrm{U}$ & $0.01 \mathrm{U}$ & $0.01 \mathrm{U}$ \\
\hline 4-Methyl-2-Pentenone & $0.01 \mathrm{U}$ & $0.01 \mathrm{u}$ & $0.01 \mathrm{U}$ & $0.01 \mathrm{u}$ & $0.01 u$ & $0.01 \mathrm{y}$ & $0.01 u$ & 0.014 & $0.01 \mathrm{U}$ & $0.01 \mathrm{u}$ \\
\hline 2-Hexenone & $0.01 \mathrm{U}$ & $0.01 \mathrm{U}$ & $0.01 \mathrm{U}$ & $0.09 \mathrm{U}$ & $0.01 \mathrm{U}$ & $0.01 \mathrm{U}$ & $0.01 \mathrm{U}$ & $0.01 \mathrm{U}$ & $0.01 \mathrm{U}$ & $0.01 \mathrm{U}$ \\
\hline Tetrachloroethene & $0.01 U$ & $0.01 \mathrm{U}$ & $0.01 \mathrm{U}$ & $0.01 U$ & $0.01 \mathrm{U}$ & $0.01 \mathrm{U}$ & $0.01 \mathrm{U}$ & $0.01 \mathrm{U}$ & $0.01 \mathrm{U}$ & $0.01 \mathrm{U}$ \\
\hline $\begin{array}{l}1,1,2,2 \text { - } \\
\text { Totrechloroethene }\end{array}$ & $0.01 U$ & $0.01 U$ & $0.01 U$ & $0.01 U$ & $0.01 \mathrm{U}$ & $0.01 U$ & $0.01 U$ & $0.01 \mathrm{U}$ & $0.01 \mathrm{U}$ & $0.01 u$ \\
\hline Toluere & $0.01 \mathrm{U}$ & $0.01 \mathrm{U}$ & $0.01 \mathrm{U}$ & $0.01 U$ & $0.01 \mathrm{U}$ & $0.01 U$ & $0.01 U$ & $0.01 \mathrm{U}$ & $0.01 \mathrm{U}$ & $0.01 \mathrm{U}$ \\
\hline Chlorobanzene & $0.01 \mathrm{U}$ & $0.01 \mathrm{U}$ & $0.01 \mathrm{U}$ & $0.01 \mathrm{U}$ & $0.01 \mathrm{U}$ & $0.01 \mathrm{U}$ & $0 . \dot{0} 1 \mathrm{U}$ & $0.01 \mathrm{U}$ & $0.01 \mathrm{U}$ & $0.01 \mathrm{u}$ \\
\hline Ethylbenzene & $0.01 \mathrm{U}$ & $0.01 \mathrm{U}$ & $0.01 U$ & $0.01 \mathrm{U}$ & $0.01 \mathrm{U}$ & $0.01 \mathrm{U}$ & $0.01 \mathrm{U}$ & $0.01 \mathrm{U}$ & $0.01 \mathrm{U}$ & $0.01 \mathrm{U}$ \\
\hline Styrene & $0.01 \mathrm{U}$ & $0.01 \mathrm{U}$ & $0.01 \mathrm{U}$ & $0.01 \mathrm{U}$ & $0.01 \mathrm{U}$ & $0.01 \mathrm{U}$ & $0.01 u$ & $0.01 \mathrm{U}$ & $0.01 \mathrm{U}$ & $0.01 \mathrm{U}$ \\
\hline xylene (total) & $0.01 \mathrm{U}$ & $0.01 \mathrm{U}$ & $0.01 \mathrm{U}$ & $0.01 \mathrm{U}$ & $0.01 \mathrm{U}$ & $0.01 \mathrm{U}$ & $0.01 \mathrm{U}$ & $0.01 \mathrm{U}$ & $0.09 \mathrm{U}$ & $0.01 \mathrm{U}$ \\
\hline
\end{tabular}

$U$ - Analyzed for but undetected

$\mathrm{J}$ - Indicates the result reported is below the contract quantitation linit. 
DOE/RL-93-96, Rev. 0

\begin{tabular}{|c|c|c|c|c|c|c|c|c|c|c|}
\hline \multirow[b]{3}{*}{ Constituents } & \multicolumn{7}{|c|}{ WATER TREATMENT RESULTS } & \multirow{2}{*}{\multicolumn{3}{|c|}{ Trip Blanks }} \\
\hline & \multicolumn{3}{|c|}{ Influent } & \multicolumn{4}{|c|}{ Effluent } & & & \\
\hline & $\begin{array}{r}\text { B09BR4 } \\
\text { water } \\
\mu \mathrm{g} / \mathrm{L} \\
\end{array}$ & $\begin{array}{r}8098 R 6 \\
\text { water } \\
\mu \mathrm{g} / \mathrm{L} \\
\end{array}$ & $\begin{array}{c}\text { B09BR7 } \\
\text { water } \\
\mu g / L \\
\end{array}$ & $\begin{array}{r}\text { B098R5 } \\
\text { water } \\
\mu g / 1 \\
\end{array}$ & $\begin{array}{r}\text { B09BR8 } \\
\text { water } \\
\mu g / L \\
\end{array}$ & $\begin{array}{r}\text { B098R9 } \\
\text { water } \\
\mu g / L \\
\end{array}$ & $\begin{array}{c}\text { B09BSO } \\
\text { dup. } \\
\mu \mathrm{g} / \mathrm{L} \\
\end{array}$ & $\begin{array}{r}\text { B09BW2 } \\
\text { water } \\
\mu \mathrm{g} / \mathrm{L}\end{array}$ & $\begin{array}{r}\text { B09BW5 } \\
\text { water } \\
\mu \mathrm{g} / \mathrm{L} \\
\end{array}$ & $\begin{array}{r}\text { B09BW8 } \\
\text { water } \\
\mu \mathrm{g} / \mathrm{L} \\
\end{array}$ \\
\hline alpha-BHC & $0.05 \mathrm{U}$ & $0.05 \mathrm{U}$ & $0.05 \mathrm{U}$ & $0.05 \mathrm{U}$ & $0.05 \mathrm{U}$ & $0.05 \mathrm{U}$ & $0.05 \mathrm{U}$ & N/A & N/A & N/A \\
\hline beta-BHC & $0.1 P$ & $0.11 P$ & $0.05 \mathrm{u}$ & $0.05 \mathrm{U}$ & $0.05 \mathrm{U}$ & $0.05 \mathrm{U}$ & $0.05 \mathrm{U}$ & N/A & N/A & $N / A$ \\
\hline delta-BHC & $0.05 \mathrm{U}$ & $0.05 \mathrm{U}$ & $0.05 \mathrm{U}$ & $0.05 \mathrm{U}$ & $0.05 \mathrm{U}$ & $0.05 \mathrm{U}$ & $0.05 u$ & N/A & $N / A$ & $N / A$ \\
\hline gemma-BHC (Lindane) & $0.05 \mathrm{U}$ & $0.05 \mathrm{U}$ & $0.05 \mathrm{U}$ & $0.05 \mathrm{U}$ & $0.05 U$ & $0.05 \mathrm{U}$ & $0.05 \mathrm{U}$ & N/A & $N / A$ & N/A \\
\hline Heptachlor & 0.26 & 1.8 & 0.82 & 0.38 & $\begin{array}{l}0.096 \\
P\end{array}$ & 0.61 & 0.97 & N/A & $N / A$ & $N / A$ \\
\hline Aldrin & $0.05 \mathrm{U}$ & $0.05 \mathrm{U}$ & $0.05 \mathrm{U}$ & $0.05 U$ & $0.05 \mathrm{U}$ & $0.05 U$ & $0.05 \mathrm{U}$ & N/A & N/A & $N / A$ \\
\hline Heptachlor epoxide & $0.05 \mathrm{U}$ & $0.05 \mathrm{u}$ & $0.05 \mathrm{U}$ & $0.05 \mathrm{U}$ & $0.05 \mathrm{U}$ & $0.05 \mathrm{U}$ & $0.05 \mathrm{U}$ & N/A & $N / A$ & $N / A$ \\
\hline Endosul fan 1 & $0.05 \mathrm{U}$ & $0.05 \mathrm{U}$ & $0.05 \mathrm{U}$ & $0.05 \mathrm{U}$ & $0.05 \mathrm{U}$ & $0.05 \mathrm{U}$ & $0.05 \mathrm{U}$ & N/A & $N / A$ & $N / A$ \\
\hline Dieldrin & $0.1 u$ & $0.1 \mathrm{U}$ & $0.1 \mathrm{U}$ & $0.1 \mathrm{U}$ & $0.1 \mathrm{U}$ & $0.1 \mathrm{U}$ & $0.1 \mathrm{U}$ & $N / A$ & $N / A$ & N/A \\
\hline 4,41-DOE & $0.1 \mathrm{U}$ & 0.10 & 0.10 & $0.1 \mathrm{U}$ & $0.1 \mathrm{u}$ & 0.10 & 0.14 & N/A & N/A & N/A \\
\hline Endrin & $0.1 \mathrm{U}$ & $0.1 \mathrm{U}$ & $0.1 \mathrm{U}$ & 0.10 & $0.1 \mathrm{U}$ & $0.1 \mathrm{U}$ & $0.1 \mathrm{U}$ & $N / A$ & N/A & $N / A$ \\
\hline Endoaul fon 11 & $0.1 \mathrm{U}$ & $0.1 \mathrm{U}$ & $0.1 \mathrm{U}$ & $0.1 U$ & $0.1 \mathrm{U}$ & $0.1 \mathrm{U}$ & $0.1 U$ & $N / A$ & $N / A$ & N/A \\
\hline $4,4 \cdot=000$ & $0.1 \mathrm{u}$ & $0.1 \mathrm{U}$ & $0.1 \mathrm{u}$ & $0.1 \mathrm{U}$ & $0.1 U$ & $0.1 \mathrm{U}$ & $0.1 \mathrm{U}$ & N/A & $N / A$ & $N / A$ \\
\hline Endosul fan sul fate & $0.1 \mathrm{U}$ & $0.1 \mathrm{U}$ & $0.1 \mathrm{U}$ & $0.1 \mathrm{U}$ & $0.1 \mathrm{U}$ & $0.1 \mathrm{U}$ & $0.1 U$ & N/A & N/A & $N / A$ \\
\hline 4.4.-DPT & 0.14 & $0.1 \mathrm{U}$ & 0.14 & $0.1 \mathrm{U}$ & $0.1 \mathrm{U}$ & $0.1 \mathrm{U}$ & $0.1 \mathrm{U}$ & $N / A$ & $N / A$ & N/A \\
\hline Methoxychlor & $0.5 \mathrm{U}$ & $0.5 \mathrm{U}$ & $0.5 U$ & $0.5 u$ & $0.5 \mathrm{U}$ & $0.5 \mathrm{U}$ & $0.5 \mathrm{U}$ & N/A & $N / A$ & $M / A$ \\
\hline Endrin ketone & $0.1 \mathrm{U}$ & $0.1 \mathrm{U}$ & $0.1 \mathrm{U}$ & $0.1 U$ & $0.1 \mathrm{U}$ & 0.10 & 0.10 & N/A & $N / A$ & $N / A$ \\
\hline Endr in aldehycs & $0.1 \mathrm{U}$ & $0.1 \mathrm{U}$ & $0.1 \mathrm{u}$ & $0.1 U$ & $0.1 \mathrm{U}$ & 0.10 & $0.1 U$ & $N / A$ & $N / A$ & $N / A$ \\
\hline alpha-chlordene & $0.05 \mathrm{U}$ & $0.05 U$ & $0.05 \mathrm{U}$ & $0.05 \mathrm{U}$ & $0.05 \mathrm{u}$ & 0.054 & $0.05 \mathrm{u}$ & $N / A$ & $N / A$ & $N / A$ \\
\hline or.m-chlordens & $0.05 \mathrm{u}$ & $0.05 \mathrm{U}$ & $0.05 \mathrm{U}$ & $0.05 \mathrm{U}$ & $0.05 \mathrm{U}$ & $0.05 \mathrm{U}$ & $0.05 \mathrm{U}$ & $H / A$ & $N / A$ & N/A \\
\hline Toxephene & $5.0 \mathrm{U}$ & $5.0 \mathrm{U}$ & $5.0 \mathrm{U}$ & $5.0 \mathrm{U}$ & $5.0 \mathrm{U}$ & 5.00 & $5.0 \mathrm{U}$ & $N / A$ & $N / A$ & $N / A$ \\
\hline Aroclor-1016 & $1.0 \mathrm{U}$ & $1.0 \mathrm{U}$ & $1.0 \mathrm{U}$ & $1.0 \mathrm{U}$ & $1.0 \mathrm{U}$ & $1.0 \mathrm{U}$ & $1.0 \mathrm{U}$ & $N / A$ & $N / A$ & $N / A$ \\
\hline Aroclor-1221 & $2.0 \mathrm{U}$ & $2.0 \mathrm{U}$ & 2.01 & 2.04 & $2.0 \mathrm{U}$ & $2.0 \mathrm{U}$ & $2.0 \mathrm{U}$ & N/A & $N / A$ & N/A \\
\hline Aroclor-1232 & $1.0 \mathrm{U}$ & 1.00 & $1.0 \mathrm{U}$ & 1.00 & $1.0 u$ & 1.00 & $1.0 \mathrm{U}$ & $N / A$ & $N / A$ & $N / A$ \\
\hline Aroclor-1242 & $1.0 \mathrm{U}$ & $1.0 \mathrm{U}$ & $1.0 \mathrm{U}$ & $1.0 \mathrm{U}$ & $1.0 \mathrm{U}$ & $1.0 \mathrm{U}$ & $1.0 \mathrm{U}$ & N/A & N/A & $N / A$ \\
\hline Aroclor-1248 & $1.0 \mathrm{U}$ & $1.0 \mathrm{U}$ & $1.0 \mathrm{U}$ & $1.0 \mathrm{u}$ & $1.0 \mathrm{U}$ & $1.0 \mathrm{U}$ & $1.0 \mathrm{U}$ & $N / A$ & $N / A$ & $N / A$ \\
\hline Aroclor-1254 & $1.0 \mathrm{U}$ & $1.0 \mathrm{U}$ & $1.0 \mathrm{U}$ & $1.0 \mathrm{U}$ & $1.0 \mathrm{U}$ & $1.0 u$ & $1.0 \mathrm{U}$ & $N / A$ & $N / A$ & $N / A$ \\
\hline Aroclor-1260 & $1.0 \mathrm{U}$ & $1.0 \mathrm{U}$ & $1.0 \mathrm{U}$ & $1.0 \mathrm{U}$ & $1.0 \mathrm{U}$ & $1.0 \mathrm{U}$ & $1.0 \mathrm{U}$ & $\mathbf{N} / \mathbf{A}$ & N/A & $N / A$ \\
\hline
\end{tabular}

U - Analyzed for but undatected

- Indicates there is areater than $25 \%$ difference for detected

concentration between the two Gas Chromatagraph colums.

The lower value is reported.

M/A - Analysis is Not Applicable for Trip Blanks 
DOE/RL-93-96, Rev. 0

APPENDIX C

VENDOR TEST

(To be included in Rev. 1 of this document) 
DOE/RL-93-96, Rev. 0

\section{DISTRIBUTION}

Number of Copies

Onsite

31

U.S. Department of Energy, Richland Operations

J. K. Erickson (30)

A5-19

Public Reading Room

A1-65

1

Pacific Northwest Laboratory

Hanford Technical Library

P8-55

30

Westinghouse Hanford Company

L. D. Arnold

B2-35

R. D. Belden (11)

H6-03

P. J. Mackey

B3-06

EPIC (7)

H6-08

ERC (G. Fitzgibbon)

H6-07

ERE (F. Stone) (2)

H6-01

ERE Project File

H6-08

ER Program Office

H6-27

IRA (3)

H4-17

Resource Center

N3-05 

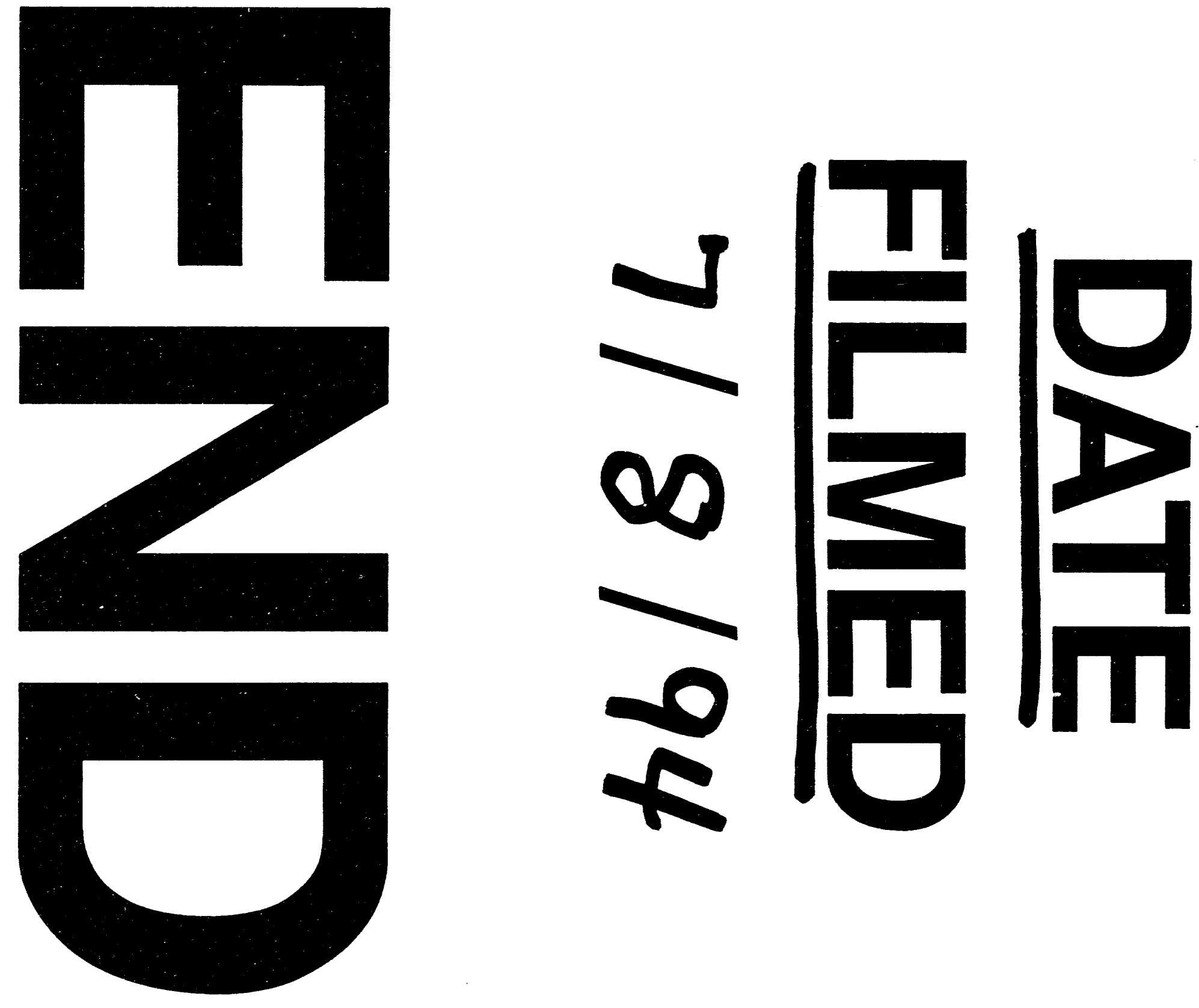
